Florida International University FIU Digital Commons

9-30-2014

\title{
Sources, Fate and Transformation of Organic Matter in Wetlands and Estuaries
}

Chao Ya

cya001@fiu.edu

DOI: $10.25148 /$ etd.FI14110708

Follow this and additional works at: https://digitalcommons.fiu.edu/etd

Part of the Analytical Chemistry Commons, and the Environmental Chemistry Commons

\section{Recommended Citation}

Ya, Chao, "Sources, Fate and Transformation of Organic Matter in Wetlands and Estuaries" (2014). FIU Electronic Theses and Dissertations. 1581.

https://digitalcommons.fiu.edu/etd/1581 


\title{
FLORIDA INTERNATIONAL UNIVERSITY
}

Miami, Florida

\section{SOURCES, FATE AND TRANSFORMATION OF ORGANIC MATTER IN WETLANDS AND ESTUARIES}

\author{
A dissertation submitted in partial fulfillment of \\ the requirements for the degree of \\ DOCTOR OF PHILOSOPHY \\ in \\ CHEMISTRY \\ by
}

Chao Ya

2014 
To: Interim Dean Michael R. Heithaus

College of Arts and Sciences

This dissertation, written by Chao Ya, and entitled Sources, Fate and Transformation of Organic Matter in Wetlands and Estuaries, having been approved in respect to style and intellectual content, is referred to you for judgment.

We have read this dissertation and recommend that it be approved.

Yong Cai

Piero R. Gardinali

Joseph N. Boyer

Yi Xiao

Rudolf Jaffé, Major Professor

Date of Defense: September 30, 2014

The dissertation of Chao Ya is approved.

Interim Dean Michael R. Heithaus

College of Arts and Sciences

Dean Lakshmi N. Reddi

University Graduate School

Florida International University, 2014 
(C) Copyright 2014 by Chao Ya

All rights reserved. 


\section{DEDICATION}

I dedicate this dissertation to my beloved parents, Ms. Li Ma and Mr. Hanfei Ya, my husband Mr Ting Xie. Without your love and support, the completion of this work would not have been possible. This dissertation is also dedicated to the memory of my grandpa Mr. Xiangcai Ma, who passed away one year before the completion of this work. 


\section{ACKNOWLEDGMENTS}

I wish to express my special thanks to my advisor, Dr. Rudolf Jaffé, for his support, guidance and help throughout this work. Without his valuable mentoring and inspiration during the past four years, the completion of this work would not have been possible. Deep thanks go to my committee members, Dr. Yong Cai, Dr. Piero Gardinali, Dr. Joseph Boyer and Dr. Yi Xiao for their support and advice during each step of my research progress.

I would like to extend my appreciation to the research collaborators: Dr. William Anderson and his student Annie Palya and lab manager John Harris for their help with the isotope measurements. Thanks go to Dr Patricia Medeiros for providing incubation samples from Georgia LTER sites; Dr Chris Craft for his valuable help with the sampling in the Altamaha River, Georgia. Deepest thanks go to Dr. Kaelin Cawley for sharing her knowledge of dissolved organic matter and technical guidance. I also greatly appreciate Dr Joseph Boyer for his valuable advice on the DOM mapping in Florida Bay chapter; Dr. Stephen Macko and Dr Donald Phillips for their constructive advice on the statistical processing of isotopic analysis. Thanks also go to the Wetland Ecosystem Laboratory, especially Rafael Travieso, Adam Hines and Olga Sanchez, for field support and the SERC Water Quality Laboratory for chlorophyll analyses.

I would like to thank National Science Foundation (NSF) through the FCE-LTER and the South Florida Water Sustainability and Climate (WSC) programs for financial support through research assistantship. The Southeast Environmental Research Center (SERC) through a Cristina Menendez Fellowship is greatly acknowledged for the support on my study in Florida Bay and conference trip to New Orleans. I also thank the 
department of Chemistry and Biochemistry at Florida International University (FIU) for supporting my studies through Teaching Assistantships.

Finally, I wish to thank my extraordinary colleagues and friends from the Organic Geochemistry Group, including Dr. Kaelin Cawley, Dr. Ding He, Dr.. Yan Ding, Dr. Laura Belicka, Dr. Oliva Pisani, Dr. Meilian Chen, Dr. Cristina Romera-Castillo, Dr. Yingxu Du, Sasha Wagner, Wenxi Huang, Peter Regier and Blanca Jarra. Special thanks go to Dr. Youhei Yamashita for his great advice on amino acid analysis. I am especially grateful to Dr. Yong Cai and Dr. Yanbin Li for introducing me to this wonderful graduate program and their warm encouragement in the past four years. It has been a valuable learning experience and wonderful journey. 


\section{ABSTRACT OF THE DISSERTATION \\ SOURCES, FATE AND TRANSFORMATION OF NATURAL ORGANIC MATTER \\ IN WETLANDS AND ESTUARIES}

by

\section{Chao Ya}

Florida International University, 2014

Miami, Florida

\section{Professor Rudolf Jaffé, Major Professor}

Dissolved organic matter (DOM) is a complex mixture of organic compounds and represents the largest reservoirs of carbon (C) on earth. Particulate organic matter (POM) is another important carbon component in $\mathrm{C}$ cycling and controls a variety of biogeochemical processes. Estuaries play important roles in retaining and transforming such organic matter (OM) and serve as both sources and sinks of DOM and POM. There is a diverse array of both autochthonous and allochthonous OM sources in wetland/estuarine ecosystems. A comprehensive study on the sources, transformation and fate of $\mathrm{OM}$ in such ecosystems is essential in advancing our understanding of $\mathrm{C}$ cycling and better constraining the global $\mathrm{C}$ budget.

In this work, DOM characteristics were investigated in different estuaries. Dissolved organic matter source strengths and dynamics were assessed in a seagrassdominated subtropical estuarine lagoon. The primary source of DOM was quantified using the combination of excitation emission matrix fluorescence with parallel factor analysis (EEM-PARAFAC) and stable C isotope analysis. Seagrass can contribute up to $72 \%$ of the DOM in the study area. The spatial and temporal variation of DOM dynamics 
was also studied in salt marsh estuary. The data showed that DOM was primarily derived from freshwater marshes and controlled by hydrology while salt marsh plants play a significant role in the distribution patterns of DOM quality and quantity. The OM dynamics was also investigated in a mangrove-dominate estuary and a comparative study was conducted between the DOM and POM pools. The results revealed both similarity and dissimilarity in DOM and POM composition. The dynamics of both OM pools are largely uncoupled as a result of source differences. Fringe mangrove export similar amounts of DOM and POM and should be considered as an important source in coastal C budgets. Lastly, chemical characterizations were conducted on the featured fluorescence component in OM in an attempt to better understand the composition and origins of the specific PARAFAC component. The traditionally defined 'protein-like' fluorescence was found to contain both proteinaceous and phenolic compounds, suggesting that the application of this parameter as a proxy for amino acid content and bioavailability may be limited. 


\section{TABLE OF CONTENTS}

CHAPTER

PAGE

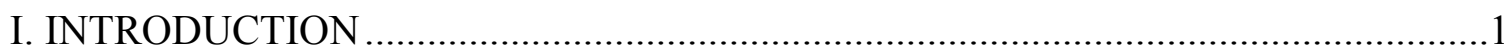

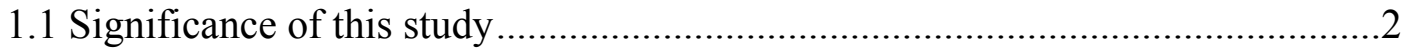

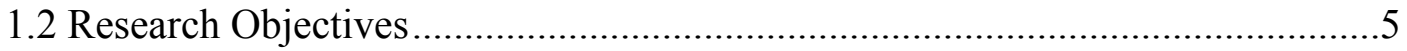

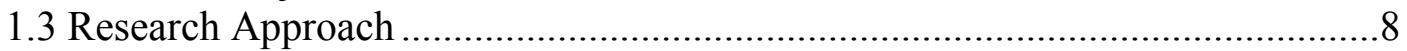

1.3.1 Excitation Emission Matrix fluorescence-Parallel Factor Analysis

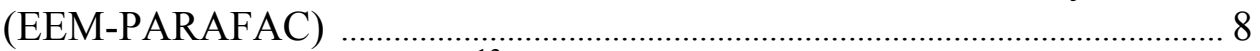

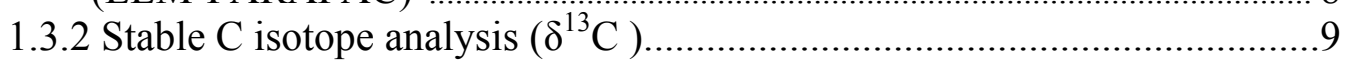

1.3.3 Chromatographic characterization ......................................................

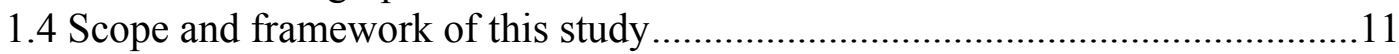

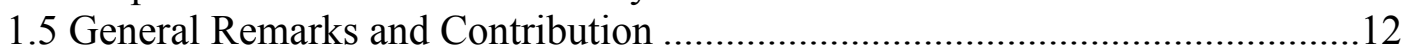

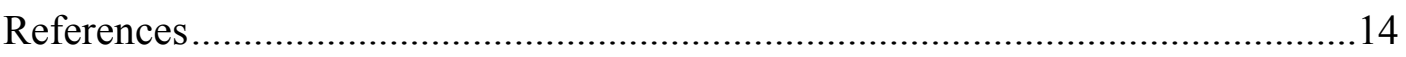

II. ASSESSING DISSOLVED ORGANIC MATTER DYNAMICS AND SOURCE

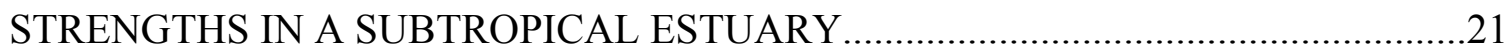

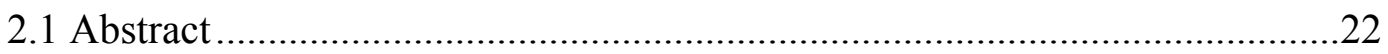

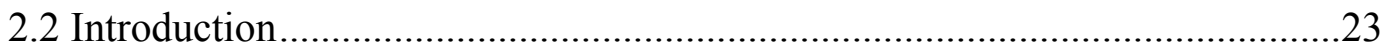

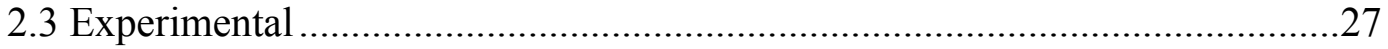

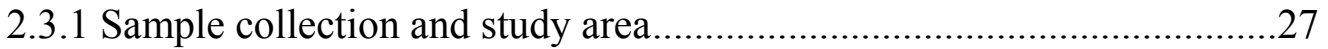

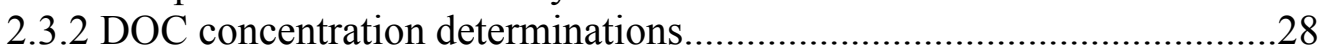

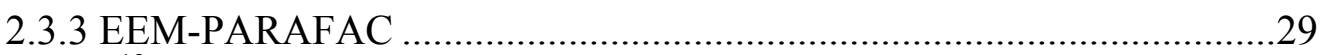

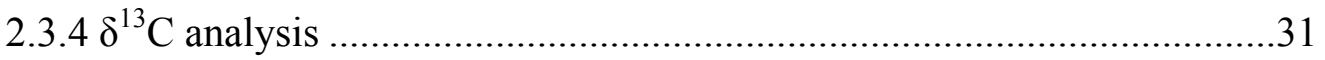

2.3.5 Statistical analysis .................................................................................... 32

2.4 Results and Discussion ...............................................................................

2.4.1 Spatial and temporal variation of stable carbon isotope and optical properties of DOM in Florida Bay ........................................................33

2.4.2 Quantification of seagrass-derived DOM in Florida Bay ........................45

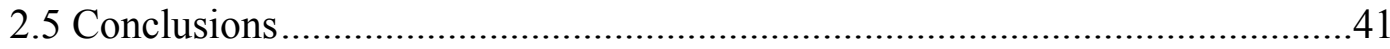

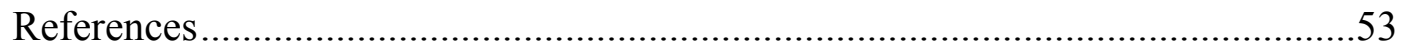

III. CHARACTERIZING SOURCES AND FATE OF DISSOVED ORGANIC MATTER IN THE ALTAMAHA RIVER ESTUARY ................................................60

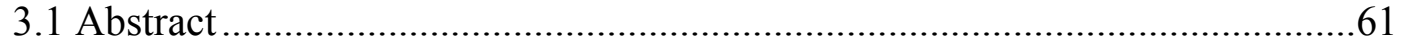

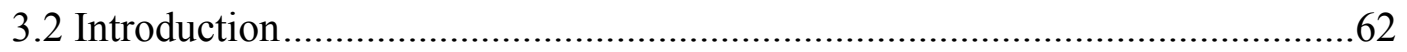

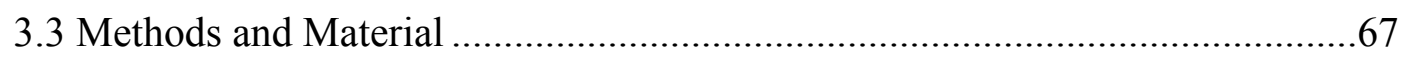

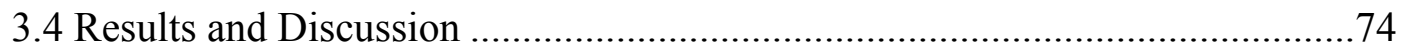

3.4.1 DOC and optical properties ...............................................................74

3.4.2 Characteristics of EEM-PARAFAC components ....................................83

3.4.2.1 EEM-PARAFAC modeling …………………..............................83

3.4.2.2 Distribution of PARAFAC components along the Altamaha

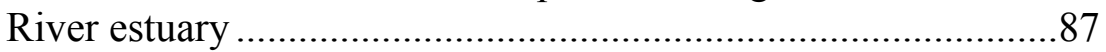

3.4.2.3 Sources and reactivity of the PARAFAC components ................91 
3.4.2.4 Principal component analysis .............................................97

3.4.3 Source characterization by stable $C$ isotope ....................................... 102

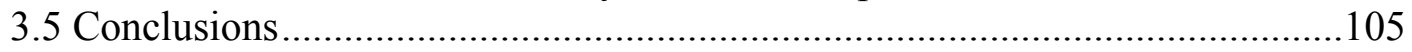

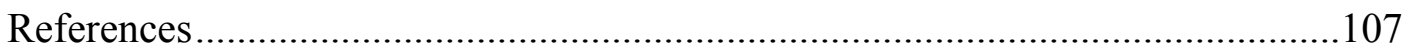

IV. ORGANIC MATTER DYNAMICS IN A MANGROVE DOMINATED ESTUARY: COMPARISONS BETWEEN DISSOLVED AND PARTICULATE

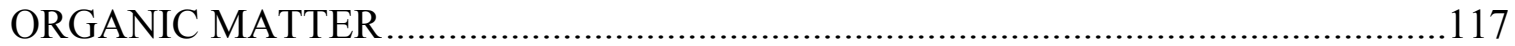

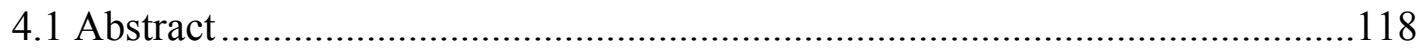

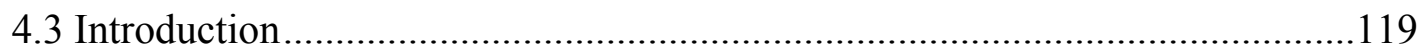

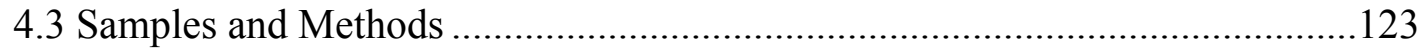

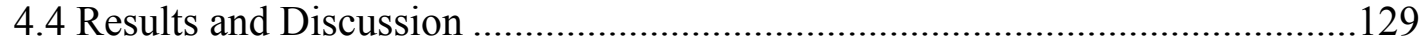

4.4.1 Measurements of bulk parameters ......................................................129

4.4.2 EEM-PARAFAC characterization for POM base extract ......................136

4.4.3 Isotopic source characterization...........................................................147

4.4.4 Mangrove-derived DOM and POM export estimates ...........................150

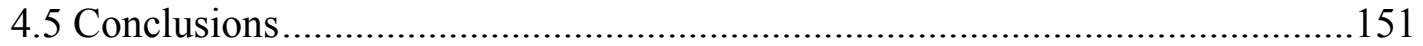

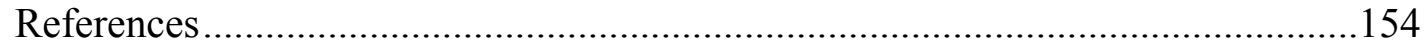

V. CHEMICAL CHARACTERIZATON OF PROTEIN-LIKE FLUOROPHORES IN

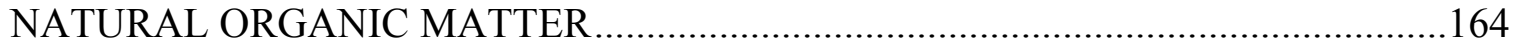

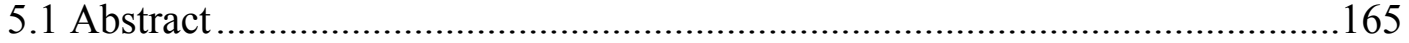

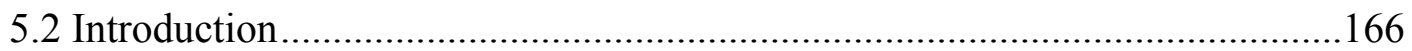

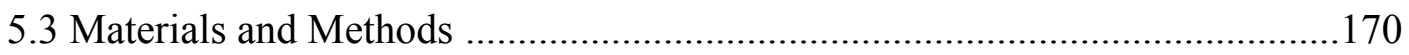

5.3.1 High Performance Liquid Chromatography with Size Exclusion (SECHPLC) analysis on the base extract of floc samples ...........................171

5.3.2 Gallic acid analysis from hydrolysable tannins .................................172

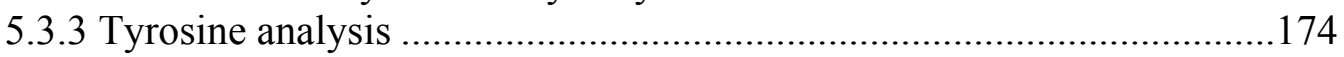

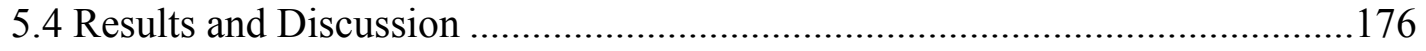

5.4.1 Preliminary finding on free form gallic acid in flocculent samples........176

5.4.2 Comparison of the fluorescence quantum yield of gallic acid and

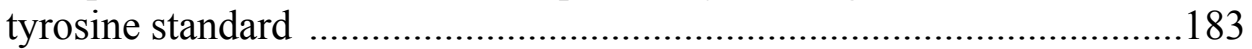

5.4.3 GC-MS analysis on gallic acid and hydrolyzed tannins ......................187

5.4.4 GC-MS analysis on tyrosine and hydrolyzed protein ..........................192

5.4.5 Comparing the strengths of gallic acid vs tyrosine in protein-like

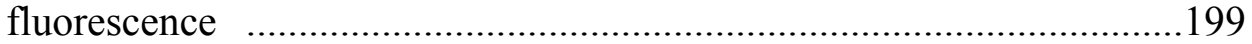

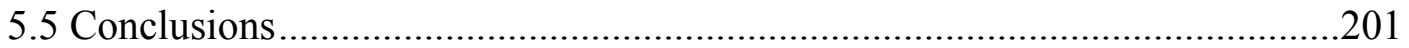

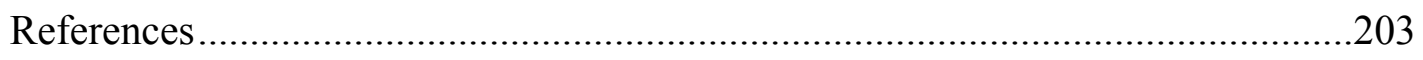

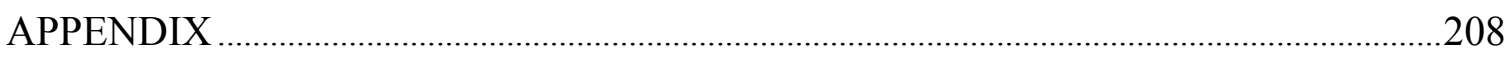

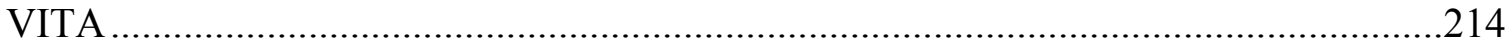




\section{LIST OF TABLES}

TABLE

PAGE

2.1 Description of sample sites. Site information was obtained from long-term water quality monitoring program

2.2 Description of the eight PARAFAC components in the Everglades' model and regression between individual PARAFAC components with $\delta^{13} \mathrm{C}$.

2.3 Comparative table of DOM characteristics (relative abundance of humic-like components, protein-like components and $\delta^{13} \mathrm{C}$ ) in different locations 32

2.4 Summary of regional and seasonal DOC, humic-like and protein-like PARAFAC components' relative abundance and DOC $\delta^{13} \mathrm{C}$ values. Two end-member mixing model estimated seagrass contributions (\%) to DOC pool are indicated. .50

3.1a DOC concentration and Optical properties of surface water/groundwater. .77

3.1b Contributions (as a percentage) from the salt marsh to DOC and PARAFAC components compared to a conservative mixing scenario.

3.2 Characteristics of the four PARAFAC components in the Altamaha estuary .86

3.3 DOC concentration and optical properties of plant/soil leachate.

$3.4 \delta^{13} \mathrm{C}$ analysis of surface water DOM in salinity zones along the Altamaha River transect.

4.1 Comparative table of POM and DOM characteristics in Shark and Harney river estuary

4.2 Sampling information: salinity, hydrological data; OM concentration, distribution pattern, flux calculation and optical properties

5.1 Organic C content, PARAFAC composition of OM samples collected at different sites of Everglades.

5.2 Quantum yield calculated for gallic acid and tyrosine standard at different concentration.

5.3 Compare the gallic acid concentration measured by GC-MS in non-hydrolyzed samples and hydrolyzed samples

5.4 GC-MS detection results of tyrosine standard, acidified tyrosine standard and fortified DOM samples 
5.5 Concentration of gallic acid, tyrosine and their contribution to protein-like

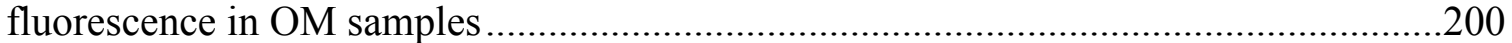




\section{LIST OF FIGURES}

FIGURE

PAGE

1.1 Example of combining the EEMs into a three-dimensional data array (Stedmon and Bro, 2008)

1.2 Structure of the monomer of hydrolysable tannins (gallic acid) and amino acid (tyrosine)

2.1 Sample sites of study region in Florida Bay indicating regions with statistically similar DOM composition. FBW=Florida Bay West; FBC $=$ Florida Bay Center; FBE= Florida Bay East......

2.2 Representative EEMs of FB surface water DOM and seagrass leachate

2.3 Spatial distribution of $\delta^{13} \mathrm{C}$-DOM during early wet season (June), late wet season (November) and dry season (April)....

2.4 Principal component analysis (PCA) for plant leachate, FB and terrestrial DOM with loading plots based on the relative abundance of the eight PARAFAC components.

2.5 Boxplot of (a) relative abundance of humic-like substances and (b) relative abundance of protein-like (c) DOC $\delta^{13} \mathrm{C}$ values in FBE, FBC and FBW during the three sampling seasons.

2.6 Correlation between DOC stable carbon isotope values $\delta^{13} \mathrm{C}$ and the relative abundance of EEM-PARAFAC components: Humic-like components $\%=$ $(\mathrm{C} 1+\mathrm{C} 2+\mathrm{C} 3+\mathrm{C} 5) \%$; Protein-like components $\%=(\mathrm{C} 7+\mathrm{C} 8) \%$ for samples collected during early wet season (June 2011), late wet season (November 2011) and dry season (April 2012) combined

3.1a Vegetation classification of the Altamaha River estuary (Higinbotham et al., 2004)

3.1b A) Map of Georgia coastal ecosystem-the study domain of Long Term Ecological Research (https://gce-lter.marsci.uga.edu/); B) Sampling transects along the Altamaha River estuary

3.2 DOC concentration along the Altamaha salinity transects in wet season and dry season (black dots: dry season; white circles: wet season). Color coded data points indicate samples from salt marsh creeks (yellow = Aug. 2010; green = Sep. 2012) .

3.3 Variation of precipitation, total fluorescence (Fmax, QSU) and DOC concentration (ppm) during the four sampling event... 
3.4 Weight of biomass collected during year 2011-2012; data from the database of ongoing Georgia coastal ecosystem long term ecological research program (http://gcelter.marsci.uga.edu). GCE-LTER stations are indicated as GCE with increasing from upper to lower estuary. Significant difference is indicated using asterisk mark.

3.5 PARAFAC components in Altamaha River ecosystem. Component1 is humic-like component, component 2 is microbial humic-like component, component 3 is protein-like component and component 4 is a fulvic acid-like component

3.6 Spatial and seasonal variation of PARAFAC components based on the fluorescence intensity of PARAFAC components (QSU) based on samples collected in Aug. 2010 (dry season) and Mar. 2011 (Wet season).

Colored dots indicated samples from salt marsh creeks.

3.7 PARAFAC composition of surface water DOM, plant and soil leachates.

3.8 Variation of PARAFAC components during the dark incubation

3.9 Principal component analysis based on the relative abundance of EEM-PARAFAC components.

3.10 Graphical representations of PC1 and PC2 values vs. salinity gradient during wet and dry seasons.

3.11 Variation of DOC- $\delta^{13} \mathrm{C}$ along the Altamaha estuary during wet season (Mar. 2012) and storm season (Sep. 2012)..

4.1 Map of Shark and Harney River transects in the Everglades, South Florida.

The dotted line in the bottom panel represents the approximate track taken for the salinity transects (from Cawley et al., 2014).

4.2 Turbidity, POM, DOC and Chl- $\alpha$ concentration along Harney River estuary during two dry seasons (Mar. 2013 and 2014) and two wet seasons ( Nov. 2012 and 2013).....133

4.3 $\mathrm{HIX}_{\mathrm{POM}}$ and $\mathrm{HIX}_{\mathrm{DOM}}$ variation along the Harney river salinity transect during four sampling seasons

4.4a EEMs of DOM and POM in fresh water and seawater: (a) fresh water POM; (b) fresh water DOM; (c) sea water POM; (d) sea water DOM..

4.4b Residual components for the EEMs of POM base extract

4.5 Relative abundance of EEM-PARAFAC components of POM and DOM in wet and dry seasons.

4.6 PCA analysis of POM and DOM along Harney River based on relative 
abundance of PARAFAC components.

4.7 Spatial distribution of POC- $\delta{ }^{13} \mathrm{C}$ isotope along Harney and Shark salinity transects

5.1 Structure of typical condensed and hydrolysable tannins (Hernes and Hedges

2000)

5.2 Analytical flow chart of gallic acid and tyrosine released from the gallotannin and proteins, respectively

5.3 EEMs of gallic acid and tannic acid standards (Ex 280nm Em 325nm)

5.4 SEC-based T-fluorophor distribution for a mangrove floc sample, gallic acid and tyrosine standards

5.5 Representative mass spectrum of gallic acid's TMS derivative 458, and the major characteristic fragmentation ions.

5.6 UV-Vis absorbance and Fluorescence $(\Lambda \mathrm{ex}=280 \mathrm{~nm})$ spectrum of tyrosine $(10 \mathrm{ppm})$ and gallic acid $(10 \mathrm{ppm})$ standard

5.7 Fluorescence intensity of gallic acid and tyrosine standard at different concentrations

5.8 GC-MS trace for hydrolyzed mangrove tannins

5.9 Gallic acid concentration detected in floc samples (freshwater and mangrove floc) after acid hydrolysis.

5.10 A. TIC of tyrosine standard derivatized by BSTFA; B. Fortified UDOM sample matrix using tyrosine standard at concentration level of 2000ng (injected amount)....

5.11 Comparison of GC-MS detection on tyrosine standard using BSTFA and IP+TFAA as derivatizing agent

5.12a TIC of IP-TFAA derivatives of amino acid in hydrolyzed BSA protein standard.

5.12b TIC of BSTFA derivatives of amino acid in hydrolyzed BSA protein standard ...199

5.13 Representative EEMs of floc base-extract .200 
CHAPTER I

INTRODUCTION 


\subsection{Significance of this study}

The exchange and reuses of materials and energy at the Earth's surface, known as biogeochemical cycles, play an important role in maintaining environmental conditions (Watson and Lovelock, 1983; Berner, 1989). Carbon, as a ubiquitous biogenic element, is one of the key elements of stiochiometric chemical reaction in biogeochemical processes (Redfield, 1958). The major forms of carbon can be classified as organic and inorganic and present as particulate $(>0.45 \mu \mathrm{m})$ or dissolved carbon $(<0.45$ $\mu \mathrm{m})$. The main reservoirs of carbon in Earth's crust hold approximately $60000 \times 10^{18} \mathrm{~g}$ of inorganic carbon and $15000 \times 10^{18} \mathrm{~g}$ of organic carbon (Olsen et al., 1985). Non-living natural organic matter is the largest active organic carbon pool on Earth (Hansell and Carlson, 2002). Among which, dissolved organic matter (DOM) is an important intermediate in the global carbon cycle (Battin et al., 2008). The significance of DOM in aquatic ecosystems has been reflected by its influences on a variety of physical, geochemical and biological processes (Scully and Lean, 1994; Cai et al., 1999; Alberts and Takacs, 1999; Del Castillo et al., 2000). The bioavailable DOM can fuel the microbial communities by serving as an important energy source, and thus affect food web dynamics (Hulatt et al., 2014). Humic substances, as a major fraction of DOM, can influence characteristics of natural aquatic systems by increasing light attenuation, acting as $\mathrm{pH}$ buffer and affecting the speciation of trace metals (Cai et al., 1999; Lu and Jaffé, 2001; Hansell and Carlson 2002; Findlay and Sinsabaugh 2003; Aitkenhead-Peterson et al., 2003). Other environmental functions of DOM include influencing fish migration habits, drinking water trihalomethane formation, hydrophobic contaminates transport and toxicity (McKnight et al., 2001; Findlay and Sinsabaugh 2003; Stabenau and Zika 2004; 
Osborne et al., 2007). Therefore, DOM has been widely studied in the past 30 years to understand the structure of DOM and the role it plays in the aquatic ecosystems.

Particulate organic matter (POM) is another important form of carbon component in the organic matter pool. It plays a vital role in carbon cycling and controls a variety of biogeochemical processes. Both POM and DOM can support autotrophic and heterotrophic production in aquatic ecosystem. The conversion of POM is critical in microbial loop dynamics and is linked to many biogeochemical processes such as decomposition, aggregation and flocculation (Wakehan and Lee, 1993). There are interactions between DOM and POM as well, mostly through sorption-desorption, photoinduced processes and leaching (Tremblay and Gagné 2009; Mayer et al., 2006; Shank et al., 2010). The size range of POM composition is diverse: sizes of constituents vary from monomers, polymers, colloids and particles. Living plankton and dead microorganisms are considered to be embedded in the structure of POM, which is dynamic on both temporal and spatial scales (Azam and Malfatti 2007). The chemical composition, sources and dynamics of POM can be very different compared with DOM, and is not well studied in complex ecosystems, such as estuaries (Osburn et al., 2010; Brym et al., 2014). In the global carbon cycle, $\mathrm{CO}_{2}$ is fixed into plant biomass and becomes the primary source of organic matter. A significant portion of C is lost in forms of DOM and POM. The export of DOM and POM from plants and salt marshes were proven quite significant (Alongi et al., 2001; Dittmar et al., 2001; Childers et al., 2006; He et al., 2014; Cawley et al., 2014). In order to balance the carbon budget, detailed understanding of DOM and POM sources, transformation and dynamics is needed. 
Globally, an estimate of $0.25 \mathrm{Pg}$ C DOM are conveyed to coastal regions annually (Hedges et al., 1997); and $700 \mathrm{Pg} \mathrm{C}$ of DOM are retained in oceanic pools (Hedges et al., 1997). In both freshwater and marine ecosystems, DOM represents the largest reactive carbon pool with an estimate of $c a .33 \%$ terrestrial organic carbon transported to the ocean through wetlands and estuaries (Stutter et al., 2008). The function of estuaries in retaining and transforming $\mathrm{OM}$ is critical for constraining global C budgets (Stallard, 1998; Hedges et al., 1997). Coastal wetlands and estuaries are vital hydrologic and biogeochemical links between land and oceans. Estuaries can serve as carbon sinks where bulk OM is modified through many biological processes such as heterotrophic degradation (McCallister et al., 2004); physical processes (e.g., flocculation, sorption and sedimentation) (Sholkovitz et al.,1978; Aufdenkampe et al.,2001, Hedges, 1992; Prahl et al.,1994) and chemical process (e.g., photolytic reactions) (Amon and Benner, 1996; Miller and Moran, 1997). Estuaries can serve as sources of OM as well. The origin of organic matter in estuaries is complex, and sources include: (1) in situ primary production (e.g., phytoplankton, zooplankton), (2) riverine sources (e.g., terrestrial plants detritus, soils and freshwater plankton), (3) material from the coastal ocean transported via tidal exchange, (4) exchange with adjacent freshwater/salt marshes (Bianchi, 2007). Quantifying the biogeochemical cycling of OM is challenging because of the multiple non-point sources. Estuarine topology (geomorphology, geophysics and hydrologic features) is also an important determinant for $\mathrm{POM} / \mathrm{DOM}$ production and transformation (Bianchi, 2007). Apart from the above factors, the heterogeneous nature of $\mathrm{OM}$ also adds to the challenges in characterizing $\mathrm{OM}$ composition and can be an obstacle for further understanding its transformation and fate 
in the natural environment. Therefore, estuaries are among the most challenging aquatic systems in which to assess the sources, fate and dynamics of OM (Hedges and Keil, 1999).

\subsection{Research Objectives}

Although the importance of wetlands and estuaries in OM cycling has been recognized, its sources, transport and fate in the estuarine mixing zone are not well constrained. Estuarine OM is derived from of a diverse array of allochotonous and autochtonous sources. Apart from riverine and marine inputs, salt marsh communities and fringe mangrove swamps in the estuary can make potential contributions to the $\mathrm{OM}$ pool. Since Teal's (1962) studies on energy flow through a salt-marsh ecosystem, there has been great interest in the contribution of coastal marshes to the carbon budget of estuaries. Salt marshes and mangrove swamps are considered to be highly productive environments within estuarine settings (Kirby and Gosselink, 1976 ;Pomeroy and Wiegert, 1981; Feliciano et al., 2014), which sequestrated in excess of 4.8-87.2 Tg C

year $^{-1}$ globally according to different estimations (Chmura et al. 2003; Duarte et al. 2005; McLeod et al. 2011). However, questions like quantitatively how much DOM is produced by salt marsh, and how DOM dynamics vary across a landscape of changing salinity and vegetation cover in the estuary need to be answered.

In addition, the dynamics of DOM in estuaries is complex. It has been well established that in estuaries (e.g. Florida Bay, South Florida, Maie et al., 2012), allochthnous DOM variations are primarily driven by hydrology, while authochonous DOM is mostly controlled by primary productivity of local biomass. However, source- 
specific confirmation can be challenging as local biomass can consist of diverse benthic organisms and from planktonic sources in the water column. Thus, source quantification of DOM in estuary is difficult, and DOM inputs from different sources need to be elucidated to better constrain carbon budgets. With regards to POM, its sources and the environmental drivers that control its abundance and composition may be quite different from the DOM in the same estuary. POM is generally considered to contain more labile components and to be less degraded compared with DOM. For example, in mangrovedominated estuaries (e.g., Everglades' coastal estuaries), the sources, composition and dynamics of POM can be quite different from the DOM. Bulk chemical characterizations are needed for a better understanding of the potential linkage between POM and DOM. Therefore, a combination of comparative analytical characterizations and statistical modeling are required to answer the above questions.

To address the questions above, the following hypotheses were examined:

Hypothesis I: While DOM in estuaries is derived from multiple non-point sources, source strengths and its dynamics on spatial and temporal scales can be accessed through a combination of analytical approaches such as optical properties and stable isotopes (Chapter 2).

Hypothesis II: Dissolved organic matter dynamics in river-dominated estuaries are usually controlled by a two end-member mixing and associated degradation processes. In sub-tropical estuaries another sources such as salt marshes or fringe mangroves add autochthonous estuarine sources of carbon. I hypothesize that these coastal communities add a significant load of DOC to the total C exported to the marine environment (Chapter 3 and 4$)$. 
Hypothesis III: POM and DOM in mangrove-dominated estuaries have very different chemical characteristics, distributional behavior and dynamics, as a result of differences in their source (Chapter 4).

Hypothesis IV: Protein-like fluorescence as determined by EEM-PARAFAC represents a combination of amino acid and polyphenol derived signals, the relative contributions of which vary depending on OM source (Chapter 5).

On the basis of the above, specific objectives of the present study are:

Objective 1: To cross-validate quantitative stable carbon isotope $\left({ }^{13} \mathrm{C}\right)$ mixing models with semi-quantitative EEM-PARAFAC indicators of source to reduce the degree of uncertainty in constraining carbon budgets in Florida Bay. With this objective in mind, I will determine the DOC concentration and optical properties of DOM across a spatial grid throughout Florida Bay during the early wet (June), late wet (November) and dry (April) season to assess DOM dynamics on spatial and temporal scales. I will then determine the $\delta^{13} \mathrm{C}$ composition of DOC and use a mass balance approach to quantify the contribution of seagrass to the DOM pool.

Objective 2: Assess the contribution of two estuarine marsh/swamp systems, the mangrove-dominated swamps of South Florida and the Spartina salt marshes of Georgia, to the estuarine DOC pool, using the combined isotope analysis and optical properties approach.

Objective 3: Compare the chemical characteristics, sources and dynamics of POM with DOM along a mangrove-dominated estuary and estimate the OM flux based on the dominant sources.

Objective 4: Develop an analytical approach to specifically characterize the chemical 
composition of the DOM components leading to the 'protein-like' fluorescence in DOM and POM.

\subsection{Research Approach}

\subsubsection{Excitation Emission Matrix fluorescence and Parallel Factor Analysis (EEM-} PARAFAC)

Many analytical approaches have been used to tackle the DOM structural puzzle. Among them, Excitation Emission Matrix (EEM) fluorescence coupled with parallel factor analysis (PARAFAC) have yielded significant advances in bulk DOM analysis (Coble 1996; Baker 2001; Stedmon and Bro 2003; Cory and McKnight 2005; Jaffé et al., 2014). Because of its high sensitivity, simplicity and high sample throughput, EEM-PARAFAC is particularly suitable in characterizing DOM over large spatial and temporal scales in environmental studies. The EEM-PARAFAC approach provides a wealth of both quantitative and qualitative information. EEMs represent different fluorescence emission characteristics measured from a series of excitation wavelengths, where compositional features of DOM can be revealed based on the location of excitation and emission peaks. The PARAFAC modeling is a multi-way (three-way) statistical method to treat fluorescence data with more than two dimensions (Fig.1.1), and fits the EEMs data array into Eq.1 by minimizing the residuals $\left(\mathrm{r}_{\mathrm{ijk}}\right)$. The $\mathrm{X}_{\mathrm{ijk}}$ is the fluorescence intensity of sample i measured at emission wavelength $\mathrm{j}$ and excitation wavelength $\mathrm{k}$. If there are $\mathrm{F}$ fluorophores, the measured fluorescence signal $\left(\mathrm{X}_{\mathrm{ijk}}\right)$ is the sum of contribution from each. The term $\mathrm{r}_{\mathrm{ijk}}$ represent the un-modeled variation. The fluorophores with identical excitation and emission signals will be modeled as organic component with information of fluorescence intensity. This is a useful way to statistically 
decompose the complex mixture of 3D fluorescence into components with defined compositional features.

$\mathrm{X}_{\mathrm{ijk}}=\sum_{f=1}^{F} \mathrm{a}_{\mathrm{if}} \mathrm{b}_{\mathrm{if}} \mathrm{c}_{\mathrm{kf}}+\mathrm{r}_{\mathrm{ijk}}, \mathrm{i}=1,2, . . \mathrm{I} ; \mathrm{j}=1,2, \ldots \mathrm{J} ; \mathrm{k}=1,2 \ldots \mathrm{K}$;

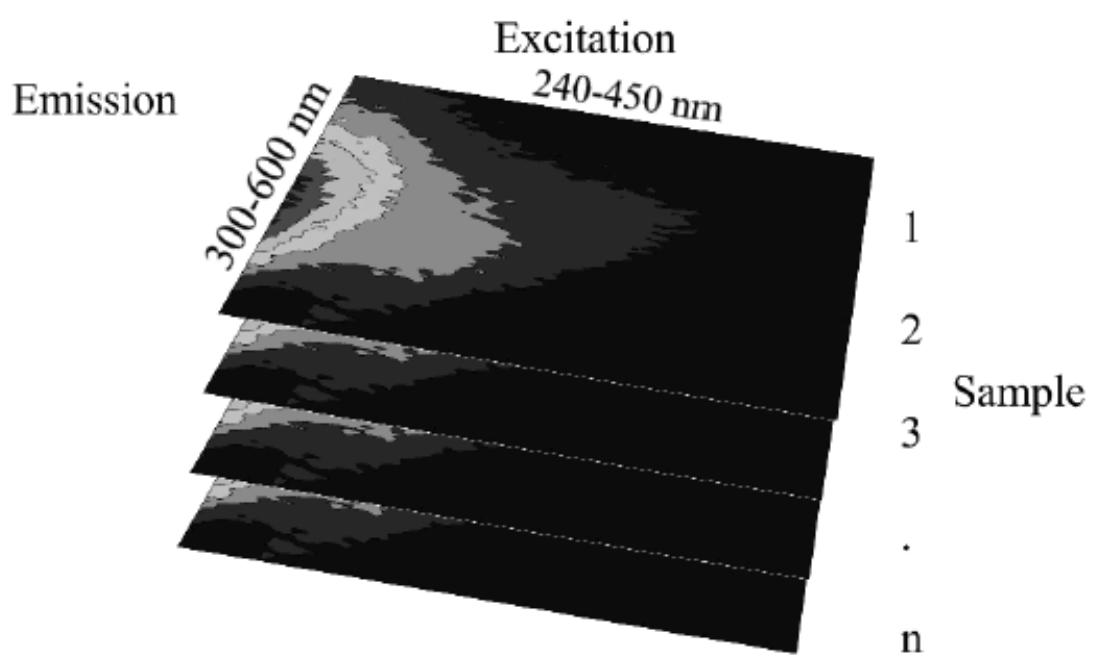

Figure 1.1 Example of combining the EEMs into a three-dimensional box of data (Stedmon and Bro, 2008)

\subsubsection{Stable C isotope analysis $\left(\delta^{13} \mathrm{C}\right)$}

Analysis of the natural abundance of stable carbon isotopes can be applied as indicator of the origin of organic matter and of trophic interactions (Fry and Sherr, 1984; Goñi et al., 1998) and as such could be an additional approach to assess DOM sources. Values of $\delta^{13} \mathrm{C}$ are reported as deviations from the standard as:

$$
\delta^{13} \mathrm{C}(\%)=\frac{{ }^{13} \mathrm{C} /{ }^{12} \mathrm{C}_{\text {sample }}-{ }^{13} \mathrm{C} /{ }^{12} \mathrm{C}_{\text {standard(PDB) }}}{{ }^{13} \mathrm{C} /{ }^{12} \mathrm{C}_{\text {standard (PDB) }}} \times 1000
$$


PDB is belemnite carbonate from the Cretaceous PeeDee formation of South Carolina, which is a commonly used standard. Most biological materials tend to be depleted in heavy isotope with $\delta^{13} \mathrm{C}$ values ranging from -5\% to -35\%o (Boutton, 1991).

Stable isotopes have proven useful tool for differentiating sources and tracking pathways of OM cycling in aquatic systems (Canuel et al., 1997; Currin et al., 1995). The $\delta^{13} \mathrm{C}$ values can be used to distinguish $\mathrm{C} 3$ and $\mathrm{C} 4$ plants showing non-overlapping $\delta^{13} \mathrm{C}$ distribution (Bouillon et al., 2008). Although DOC- ${ }^{13} \mathrm{C}$ measurements may overlap for different DOC precursor, the difference in this value between DOM derived from salt marsh plants and terrestrial sources can be very significant if these represent $\mathrm{C} 3$ and $\mathrm{C} 4$ or C4-like biomass (e.g. Spartina and seagrass are C4 and C4 type respectively). As such, mass balance quantification have been used to evaluate source strengths of DOC (Raymond and Bauer, 2001; Gordon and Goni, 2003; McCallister et al., 2004). For undetermined equations (i.e. multiple sources), statistical simulations can be applied (e.g. IsoSource modeling, Phillips and Gregg 2003).

\subsubsection{Characterization of 'protein-like' fluorescence}

Protein-like fluorescence has been suggested as derived from the amino acids tryptophan and tyrosine contained in free amino acids, peptides and proteins associated with DOM (Yamashita and Tanoue 2003). However, interferences in this fluorescence from polyphenols have been suggested (Maie et al., 2007; Hernes et al., 2009). Polyphenols, such as hydrolysable tannins are synthesized by a variety of plants (Okuda et al., 1990; Kumar and Vaithiyanathan, 1990), which are major contributors to terrigenous organic matter. Gallic acid is the basic structural unit of hydrolysable tannin, and is structurally similar to tyrosine (Fig.1.2), thus capable of emitting protein-like 
fluorescence. Therefore, applying the protein-like fluorescence as a proxy from tryptophan and tyrosine might overestimate the actual protein content in DOM. In order to better understand the composition of such protein-like fluorophores, an analytical approach to separately quantify the fluorescence derived from gallic acid and from tyrosine needs to be developed. Several different types of chromatographic techniques are applicable to tannin analysis and significant progress was achieved in this field (Mueller-Harvey, 2001). Gas chromatography and mass spectrometry (GC-MS) determination on the silylated phenolic compound was proved to be selective and sensitive for detection of gallic acid (Tor et al., 1996). In addition, GC-MS analysis of derivatized amino acid has been proven feasible in biological samples (Macko et al., 1997; Kaspar et al., 2008). However, while amino acid analyses in DOM samples have been commonly performed (e.g. Yamashita and Tanoue, 2003), no such data is available for gallic acid. My preliminary data on the methodology to determine the comparative contributions from such analytes to the overall protein-like fluorescence in DOM is presented as chapter 5 in this thesis.

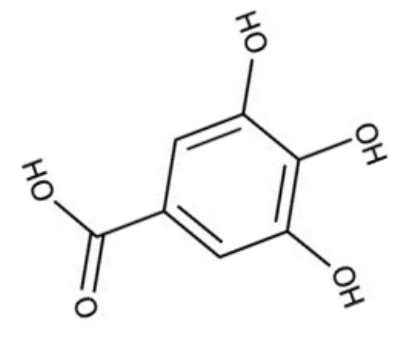

Gallic acid<smiles>NC(Cc1ccc(O)cc1)C(=O)O</smiles>

Tyrosine

Figure 1.2 Structure of the monomer of hydrolysable tannins (gallic acid) and amino acid (tyrosine) 


\subsection{Scope and framework of this dissertation}

In addition to this introductory chapter, this dissertation contains an additional four chapters, which were organized in the following way:

Chapter 1: Assessing dissolved organic matter dynamics and source strengths in a subtropical estuary: application of stable carbon isotopes and optical properties.

Chapter 2: Characterizing sources, fate and dynamics of dissolved organic matter in the Altamaha River estuary.

Chapter 3: Organic matter dynamics in a mangrove-dominated estuary: linking POM with DOM

Chapter 4: Chemical characterization of protein-like fluorophores in natural organic matter.

\subsection{General Remarks and Contributions}

- The combined techniques of EEM-PARAFAC and stable carbon isotope were proven feasible in assessing DOM sources in Florida Bay. The DOM characteristics in this seagrass dominated subtropical lagoon were well studied on both temporal and spatial scales. Source-specific quantification was achieved through mass balance quantification. It was determined that seagrass communities make a significant contribution to the DOM pool in this subtropical estuary.

- Contributions from salt marshes to the DOM pool in the Altamaha estuary and from the fringe mangrove swamps of the Shark and Harney rivers were determined. The flux of mangrove input was estimated as significant for both the DOM and POM pools. Similar contributions from the Spartin/Juncus dominated salt marshes in the Altamaha 
estuary were determined although found not to be as significant in this strongly headwater-dominated system.

- Using multiple techniques, detailed characterization of POM sources, composition and dynamics in a mangrove-dominated estuary was accomplished. A clear decoupling between POM and DOM sources in this estuary was successfully determined, which contributes to our understanding of the linkage between important carbon components in the carbon cycling.

- A GC-MS analytical approach was successfully developed in an attempt to reevaluate the origin of the traditionally defined protein-like component in EEMs. This raises the attention on the limitation of this fluorescence technique in assessing amino acid contributions to DOM. 


\section{REFERENCES}

Alberts, J.J., Takacs, M., 1999. Importance of humic substances for carbon and nitrogen transport into southeastern United States estuaries. Organic Geochemistry 30, 385- 395.

Azam, F., Malfatti, F., 2007. Microbial structuring of marine ecosystems. Nature Reviews Microbiology 5, 782-791.

Alongi,D.M., Wattayakorn,G., Pfitzner,J., Tirendi,F., Zagorskis,I., Brunskill,G.J., Davidson,A., Clough,B.F., 2001. Organic carbon accumulation and metabolic pathways in sediments of mangrove forests in souther Thailand. Marine Geology 179, 85-103.

Aufdenkampe, A. K., Hedges, J. I., Richey, J. E., Krusche, A. V., Llerena, C. A., 2001. Sorptive fractionation of dissolved organic nitrogen and amino acids onto fine sediments within the Amazon Basin. Limnology and Oceanography 46, 1921-1935.

Amon, R. M., \& Benner, R., 2003. Combined neutral sugars as indicators of the diagenetic state of dissolved organic matter in the Arctic Ocean. Deep Sea Research Part I: Oceanographic Research Papers 50, 151-169.

Aitkenhead-Peterson, J. A., McDowell, W. H., Neff, J. C., Stuart, E. G. F., \& Robert, L. S., 2003. Sources, production, and regulation of allochthonous dissolved organic matter inputs to surface waters. San Diego: Academic Press.

Baker, A., 2001. Fluorescence Excitation-Emission Matrix Characterization of Some Sewage-Impacted Rivers. Environmental Science and Technology 35, 948-953.

Boutton, T. W., 1991. Stable carbon isotope ratios of natural materials: II. Atmospheric, terrestrial, marine, and freshwater environments. Carbon Isotope Techniques 1, 173.

Bianchi, T. S., Pennock, J. R., Twilley, R. R. (Eds.). 1999. Biogeochemistry of Gulf of Mexico estuaries. John Wiley \& Sons.

Berner, R.A.,1989.Biogeochemical cycles of carbon and sulphur and their effect of atmospheric oxygen over Phanerozoit time. Palaeogeography, Palaeoclimatology, Palaeoecology 75, 97-122.

Battin, T. J., Kaplan, L. A., Findlay, S., Hopkinson, C. S., Marti, E., Packman, A. I., Sabater, F., 2008. Biophysical controls on organic carbon fluxes in fluvial networks. Nature Geoscience 1, 95-100.

Brym, A., Paerl, H. W., Montgomery, M. T., Handsel, L. T., Ziervogel, K., \& Osburn, C. L., 2014. Optical and chemical characterization of base-extracted particulate organic matter in coastal marine environments. Marine Chemistry 162, 96-113. 
Bouillon, S., Connolly, R. M., Lee, S. Y., 2008. Organic matter exchange and cycling in mangrove ecosystems: recent insights from stable isotope studies. Journal of Sea Research 59, 44-58.

Cai, Y., Jaffé, R., Jones, R.D., 1999. Interaction between dissolved organic carbon and mercury species in surface waters of the Florida Everglades. Applied Geochemistry 14, $395-407$.

Cawley, K. M., Yamashita, Y., Maie, N., Jaffé, R., 2014. Using optical properties to quantify fringe mangrove inputs to the dissolved organic matter (DOM) pool in a subtropical estuary. Estuaries and Coasts 37, 399-410.

Coble, P.G. 1996. Characterization of marine and terrestrial DOM in seawater using excitation-emission matrix spectroscopy. Marine Chemistry 51, 325-346.

Cory, R. M., McKnight, D. M. 2005. Fluorescence spectroscopy reveals ubiquitous presence of oxidized and reduced quinones in dissolved organic matter. Environmental Science and Technology 39, 8142-8149.

Canuel, E. A., Freeman, K. H., Wakeham, S. G., 1997. Isotopic compositions of lipid biomarker compounds in estuarine plants and surface sediments. Limnology and Oceanography 42, 1570-1583.

Currin, C. A., Newell, S. Y., Paerl, H. W., 1995. The role of standing dead Spartina alterniflora and benthic microalgae in salt marsh food webs: considerations based on multiple stable isotope analysis. Oceanographic Literature Review 42. 99-116.

Chmura, G.L., Anisfeld,S.C., Cahoon, D.R., Lynch, J.C., 2003. Global carbon sequestration in tidal, saline wetland soils. Global Biogeochemical Cycles 17, 1111-1123.

Childers, D.L., Boyer, J.N., Davis, S.E., Madden, C.J., Rudnick, D.T. and Sklar, F.H. ,2006 Relating precipitation and water management to nutrient concentrations in the oligotrophic "upside-down" estuaries of the Florida Everglades. Limnology and Oceanography 51, 602-616.

Del Castillo, C.E., Gilbes, F., Coble, P.G., Muller-Karger, F.E., 2000. On the dispersal of colored dissolved organic matter over the West Florida Shelf. Limnology and Oceanography 45, 1425-1432.

Duarte, C.M., Middelburg, J.J., Caraco, N., 2005. Major role of marine vegetation on the oceanic carbon cycle. Biogeosciences 2, 1-8.

Dittmar, T., Lara, R.J. and Kattner, G.,2001. River or mangrove? Tracing major organic matter sources in tropical Brazilian coastal waters. Marine Chemistry 73, 253-271. 
Findlay, S. E., Sinsabaugh, R. L., Sobczak, W. V., Hoostal, M., 2003. Metabolic and structural response of hyporheic microbial communities to variations in supply of dissolved organic matter. Limnology and Oceanography 48, 1608-1617.

Findlay, S. E. G., Sinsabaugh, R. L., Aquatic Ecosystems: Interactivity of Dissolved Organic Matter. Academic Press, 2003. San Diego. USA

Fellman, J. B., Hood, E., Spencer, R. G., 2010. Fluorescence spectroscopy opens new windows into dissolved organic matter dynamics in freshwater ecosystems: A review. Limnology and Oceanography 55, 2452-2462.

Feliciano, E. A., Wdowinski, S., Potts, M. D., 2014. Assessing Mangrove Above-Ground Biomass and Structure using Terrestrial Laser Scanning: A Case Study in the Everglades National Park. Wetlands 34, 955-968.

Fry, B., Sherr, E. B., 1989. $\delta^{13} \mathrm{C}$ measurements as indicators of carbon flow in marine and freshwater ecosystems. In Stable isotopes in ecological research. Springer New York.

Gordon, E. S., Goñi, M. A., 2003. Sources and distribution of terrigenous organic matter delivered by the Atchafalaya River to sediments in the northern Gulf of Mexico. Geochimica et Cosmochimica Acta 67, 2359-2375.

Goñi, M. A., Ruttenberg, K. C., Eglinton, T. I., 1998. A reassessment of the sources and importance of land-derived organic matter in surface sediments from the Gulf of Mexico. Geochimica et Cosmochimica Acta 62, 3055-3075.

Hansell, D.A. and Carlson, C.A. Biogeochemistry of Marine Dissolved Organic Matter. Chapter 10: Chromophoric DOM in the Coastal Environment, Academic Press.2002. London. UK

Hulatt, C. J., Kaartokallio, H., Asmala, E., Autio, R., Stedmon, C. A., Sonninen, E., Thomas, D. N., 2014. Bioavailability and radiocarbon age of fluvial dissolved organic matter (DOM) from a northern peatland-dominated catchment: effect of land-use change. Aquatic Sciences 76, 393-404.

Hernes, P.J., Benner, R., Cowie, G.L., Goni, M.A., Bergamaschi, B.A. and Hedges, J.I., 2001. Tannin diagenesis in mangrove leaves from a tropical estuary: A novel molecular approach. Geochimica et Cosmochimica Acta 65, 3109-3122.

Hernes, P. J., Bergamaschi, B. A., Eckard, R. S., Spencer, R. G., 2009.

Fluorescence-based proxies for lignin in freshwater dissolved organic matter. Journal of Geophysical Research: Biogeosciences 114, 1-10.

Hedges, J. I., 1992. Global biogeochemical cycles: progress and problems. Marine Chemistry 39, 67-93. 
Hedges, J. I., Keil, R. G., Benner, R., 1997. What happens to terrestrial organic matter in the ocean? Organic Geochemistry 27, 195-212.

Hedges, J. I.,Keil, R. G., 1995. Sedimentary organic matter preservation: an assessment and speculative synthesis. Marine Chemistry 49, 81-115.

Jaffé, R., Boyer, J. N., Lu, X., Maie, N., Yang, C., Scully, N. M., Mock, S., 2004. Source characterization of dissolved organic matter in a subtropical mangrove-dominated estuary by fluorescence analysis. Marine Chemistry 84, 195-210.

He, D., Mead, R. N., Belicka, L., Pisani, O., Jaffé, R.,2014. Assessing source contributions to particulate organic matter in a subtropical estuary: A biomarker approach. Organic Geochemistry 75, 129-139

Hernes, P. J., Bergamaschi, B. A., Eckard, R. S., Spencer, R. G. (2009).

Fluorescence-based proxies for lignin in freshwater dissolved organic matter. Journal of Geophysical Research: Biogeosciences, 114 G00F03

Jaffé R., Cawley K., and Yamashita Y., 2014. Applications of excitation emission matrix fluorescence with parallel factor analysis (EEM-PARAFAC) in assessing environmental dynamics of natural dissolved organic matter (DOM) in aquatic environments: A review. Advances in the Physicochemical Characterization of Organic Matter, ACS Series.27-73

Jaffé, R., Yamashita, Y., Maie, N., Cooper, W. T., Dittmar, T., Dodds, W. K.,Watanabe, A. 2012. Dissolved organic matter in headwater streams: compositional variability across climatic regions of North America. Geochimica et Cosmochimica Acta 94, 95-108.

Kaspar, H., Dettmer, K., Gronwald, W., Oefner, P. J., 2008. Automated GC-MS analysis of free amino acids in biological fluids. Journal of Chromatography B 870, 222-232.

Koch, B. P., Ludwichowski, K. U., Kattner, G., Dittmar, T.,Witt, M., 2008. Advanced characterization of marine dissolved organic matter by combining reversed-phase liquid chromatography and FT-ICR-MS. Marine Chemistry 111, 233-241.

Kumar, R., Vaithiyanathan, S., 1990. Occurrence, nutritional significance and effect on animal productivity of tannins in tree leaves. Animal feed science and technology 30, 21 38.

Kirby, C.J., Gosselink, J.G., 1976. Primary production in a Louisiana Gulf Coast Spartina alterniflora marsh. Ecology 57, 1052-1059.

Lu, X., Jaffe, R., 2001. Interaction between Hg (II) and natural dissolved organic matter: a fluorescence spectroscopy based study. Water Research 35, 1793-1803. 
Maie, N., Yamashita, Y., Cory, R., Boyer, J.N., Jaffé, R., 2012. Application of excitation emission matrix fluorescence monitoring in the assessment of spatial and seasonal drivers of dissolved organic matter composition: sources and physical disturbance controls. Applied Geochemistry 27, 917-929.

Maie, N., Scully, N.M., Pisani, O. and Jaffe, R., 2007 Composition of a protein-like fluorophore of dissolved organic matter in coastal wetland and estuarine ecosystems. Water Research 41, 563-570

Macko, S. A., Uhle, M. E., Engel, M. H., \& Andrusevich, V.,1997. Stable nitrogen isotope analysis of amino acid enantiomers by gas chromatography/combustion/isotope ratio mass spectrometry. Analytical Chemistry 69, 926-929.

McKnight, D.M., Boyer, E.W., Westerhoff, P.K., Doran, P.T., Kulbe, T., Anderson, D.T., 2001. Spectrofluorometric characterization of dissolved organic matter for the identification of precursor organic material and aromaticity. Limnology and Oceanography 46, 38- 48 .

Mayer, L. M., Schick, L. L., Skorko, K., Boss, E., 2006. Photodissolution of particulate organic matter from sediments. Limnology and Oceanography 51, 1064-1071.

Mueller-Harvey, I., 2001. Analysis of hydrolysable tannins. Animal Feed Science and Technology 91, 3-20.

McCallister, S. L., Bauer, J. E., Cherrier, J. E., Ducklow, H. W., 2004. Assessing sources and ages of organic matter supporting river and estuarine bacterial production: A multiple-isotope $\left(\delta^{14} \mathrm{C}, \delta{ }^{13} \mathrm{C}\right.$, and $\left.\delta{ }^{15} \mathrm{~N}\right)$ approach. Limnology and Oceanography 49 , 1687-1704.

Miller, W. L., Moran, M. A., 1997. Interaction of photochemical and microbial processes in the degradation of refractory dissolved organic matter from a coastal marine environment. Limnology and Oceanography 42, 1317-1324.

McLeod, E., Chmura, G.L., Bouillon,S., Salm,R., Björk,M., Duarte,C.M., Lovelock,C.E., Schlesinger, W.H., Silliman,B.R., 2011. A blueprint for blue carbon: toward an improved understanding of the role of vegetated coastal habitats in sequestering $\mathrm{CO}_{2}$. Fronties in Ecology and the Environment 9, 552-560.

Olsen, C. R., Larsen, I. L., Lowry, P. D., Cutshall, N. H., Todd, J. F., Wong, G. T. F., Casey, W. H. , 1985. Atmospheric fluxes and marsh-soil inventories of 7Be and 210Pb. Journal of Geophysical Research: Atmospheres 90, 10487-10495.

Osburn, C.L., Handsel, L.T., Mikan, M.P., Paerl, H.W., Montgomery, M.T., 2012. Fluorescence tracking of dissolved and particulate organic matter quality in a riverdominated estuary. Environmental Science and Technology 46, 8628-8636. 
Yoshida, T., Hatano, T., Okuda, T.,1989. Chromatography of tannins: IV. Separation of labile oligomeric hydrolysable tannins and related polyphenols by centrifugal partition chromatography. Journal of chromatography A 467, 139-147.

Pomeroy,L.R., and R.G.Wiegert.1981.The Ecology of a Salt Marsh. Springer Verlag, New York.

Phillips, D. L., Gregg, J. W., 2003. Source partitioning using stable isotopes: coping with too many sources. Oecologia 136, 261-269.

Raymond, P. A.,Bauer, J. E., 2001. Use of $\delta^{14} \mathrm{C}$ and $\delta^{13} \mathrm{C}$ natural abundances for evaluating riverine, estuarine, and coastal DOC and POC sources and cycling: a review and synthesis. Organic Geochemistry 32, 469-485.

Scully, N.M., Lean, D.R.S., 1994. The attenuation of ultraviolet light in temperature lakes. Archiv für Hydrobiologie 43, 135-144.

Stabenau, E. R., Zika, R. G., 2004. Correlation of the absorption coefficient with a reduction in mean mass for dissolved organic matter in southwest Florida river plumes. Marine Chemistry 89, 55-67.

Shank, G. C., Zepp, R. G., Vähätalo, A., Lee, R., Bartels, E., 2010. Photobleaching kinetics of chromophoric dissolved organic matter derived from mangrove leaf litter and floating Sargassum colonies. Marine Chemistry 119, 162-171.

Stutter, M. I., Langan, S. J., Cooper, R. J., 2008. Spatial and temporal dynamics of stream water particulate and dissolved $\mathrm{N}, \mathrm{P}$ and $\mathrm{C}$ forms along a catchment transect, $\mathrm{NE}$ Scotland. Journal of Hydrology 350, 187-202.

Stallard, R. F., 1998. Terrestrial sedimentation and the carbon cycle: coupling weathering and erosion to carbon burial. Global Biogeochemical Cycles 12, 231-257.

Sholkovitz, E. R., 1983. The geochemistry of plutonium in fresh and marine water environments. Earth-Science Reviews 19, 95-161.

Stedmon, C.A. and Bro, Rasmus., 2008. Characterizing dissolved organic matter fluorescence with parallel factor analysis: a tutorial. Limnology and Oceanography: Methods 6, 572-579.

Tor, E. R., Francis, T. M., Holstege, D. M., Galey, F. D.,1996. GC/MS determination of pyrogallol and gallic acid in biological matrices as diagnostic indicators of oak exposure. Journal of Agricultural and Food Chemistry 44, 1275-1279. 
Tzortziou, M., Neale, P.J., Osburn, C.L., Megonigal, J.P., Maie, N., Jaffé, R., 2008. Tidal marshes as a source of optically and chemically distinctive colored dissolved organic matter in the Chesapeake Bay. Limnology and Oceanography 53, 148-159.

Watson, A. J.,Lovelock, J. E., 1983. Biological homeostasis of the global environment: the parable of Daisyworld. Tellus B 35, 284-289.

Wakeham, S. G., Lee, C., 1989. Organic geochemistry of particulate matter in the ocean: The role of particles in oceanic sedimentary cycles. Organic Geochemistry 14, 83-96.

Yamashita, Y., Tanoue, E., 2003. Chemical characterization of protein-like fluorophores in DOM in relation to aromatic amino acids. Marine Chemistry 82, 255-271. 
CHAPTER II

ASSESSING DISSOLVED ORGANIC MATTER DYNAMICS AND SOURCE STRENGTHS IN A SUBTROPICAL ESTUARY: APPLICATION OF STABLE CARBON ISOTOPES AND OPTICAL PROPERTIES.

(This chapter is submitted to Continental shelf research and under moderate revision) 


\subsection{Abstract}

The dynamics of dissolved organic matter (DOM) in subtropical coastal bays are complex. For example, variations in DOM characteristics and sources in Florida Bay are believed to be mainly driven by both hydrology and associated runoff of terrestrial DOM, and by primary productivity mostly from seagrass sources. However, confirmation and quantification of different DOM sources are still incomplete and needed for carbon budget assessments. Optical parameters based on excitation emission matrix fluorescence coupled with parallel factor analysis (EEM-PARAFAC) that had previously been tentatively assigned to both terrestrial and seasgrass sources. These correlated linearly with determined $\delta^{13} \mathrm{C}$ values, confirming an allochthonous, hydrologically-driven terrestrial source for the humic-like fluorescent components, while authochthonous DOM reflected by the protein-like fluorescence is mainly derived through primary productivity of seagrass communities. This study demonstrated the feasibility of combining optical signatures and stable isotopes in advancing the understanding of DOM dynamics in estuarine systems. Using stable carbon isotopic signatures of DOM, and applying a simple two end-member mixing model, the relative contributions of these two sources to the DOM pool in the bay were estimated. Results indicate that the highest proportion of DOM (ca. $72 \%)$ during the dry season was seagrass-derived, but clear variations were observed on both spatial and temporal scales. Limitations to the application of optical properties for the quantitative estimation of DOM sources in such coastal systems are discussed. 


\subsection{Introduction}

Dissolved organic matter (DOM) is the largest reservoir of organic matter in the ocean, and one of the largest reactive pools of carbon on earth (Hansell and Carlson, 2002). Estuaries play a vital role in the global carbon cycle either as sources of organic matter to the open ocean or as carbon sinks due to accumulation of OM in sediments (Prahl et al., 1994). Globally, an estimated 0.25 Pg C DOM are conveyed to coastal regions annually through estuaries (Hedges et al., 1997). The functions of estuaries in retaining and transforming $\mathrm{OM}$ is critical for constraining global $\mathrm{C}$ budgets (Hedges et al.,1997; Stallard, 1998). Therefore, accurately assessing the contribution of different sources to the estuarine DOM pool is needed to gain a better understanding of carbon cycling in coastal environments.

Mangrove forests and seagrass beds are both highly productive ecosystems, and are known to represent major sources of sedimentary, particulate (POM) and dissolved (DOM) organic matter in estuaries (Holmer et al., 2001; Bouillon et al., 2007; Maher and Eyre, 2011). As such, both play important roles in the carbon budget of estuaries (Kirkman and Reid, 1979; Rivera-Monroy et al., 2011). Estimates of the global estuarine DOM flux indicate that macrophytes (seagrass and macroalgae), mangroves and salt

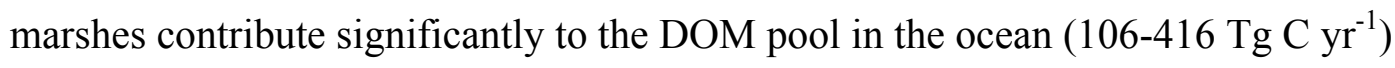
(Maher and Eyre, 2010) and up to $5 \mathrm{mmol} \mathrm{C} \mathrm{m}^{-2} \mathrm{~d}^{-1}$ net DOC flux has been estimated from the seagrass Thalassia in three temperate Australian estuaries (Maher and Eyre 2010). A similar estuarine ecosystem is Florida Bay (FB), located in the southern most section of the Florida peninsula. FB is a shallow, seagrass-dominated, subtropical, estuarine lagoon, featuring fringe mangrove systems and mangrove islands scattered 
throughout the bay. Indeed, the productivity of the extensive seagrass meadows of south Florida has been reported as averaging $0.70 \mathrm{~g} \mathrm{~m}^{-2} \mathrm{day}^{-1}$ (Fourqurean et al., 2001). Stabenau et al. (2004) reported on the dynamics and production of chromophoric DOM (CDOM) from seagrass detritus in coastal south Florida and Xu et al (2007) showed the paleo-oceanographic significance in seagrass $\mathrm{OM}$ accumulation in sediments of FB and the importance of seagrass communities as a source of POM (Xu and Jaffé, 2007). With regards to DOM, Maie et al. (2005) reported that based on NMR studies as much as $80 \%$ of the DOM in FB was present as carbohydrates and suggested it to be mainly derived from seasgrass. In addition, using optical properties, Maie et al. (2012) suggested that seasonal patterns in DOM characteristics in FB were driven through a combination of seagrass primary productivity and hydrological runoff from the Everglades.

While the importance of seagrass as a carbon source in estuaries has been clearly identified (Bouillon et al., 2007; Zielger and Benner, 2000), the assessment of their contribution compared to other estuarine carbon sources has been limited. Indeed, while seagrass beds co-occurring with fringe mangroves were reported as major source of carbon in coastal lagoons (Kieckbusch et al., 2004; Bouillon et al., 2007), fringe mangroves (Jaffé et al., 2004; Maie et al., 2012) and freshwater marshes (Lu et al., 2003) have clearly been identified as adding to the seagrass-derived carbon pool. However, the source specific quantification (e.g. seagrass vs. mangrove vs. freshwater marsh) of DOM remains largely undetermined.

As mentioned above, assessing allochthonous vs. autochthonous contributions to the DOM pool in estuaries and coastal bays a complex task. EEM-PARAFAC has been proven to be very successful in characterizing DOM sources and dynamics in diverse 
aquatic ecosystems (Jaffé et al., 2014), and was applied to characterize DOM dynamics qualitatively in FB (Maie et al., 2012). Additionally, analysis of the natural abundance of stable carbon isotopes can be applied as an indicator of the origin of organic matter (Lambert et al., 2013), and as such could be combined with EEM-PARAFAC to assess the strengths of DOM sources (Osburn and Steadmon, 2011). $\delta^{13} \mathrm{C}$ values can be used to distinguish OM derived from $\mathrm{C}-3$ and $\mathrm{C}-4$ plants showing non-overlapping $\delta^{13} \mathrm{C}$ distributions (Bouillon et al., 2007). Although DOM- $\delta{ }^{13} \mathrm{C}$ values for C-3 plants may overlap with those of plankton-derived DOM sources (higher plants vs. algae), the difference in this value between mangroves and seagrasses is very distinct as these represent C-3 and C-4-like biomass respectively (Loneragan et al., 1997; Zieman et al., 1984). Seagrasses have been reported as typically featuring enriched $\delta^{13} \mathrm{C}$ values relative to other primary producers in estuaries (Hemminga and Mateo, 1996), with values usually ranging between -16 and $-12 \%$. Anderson and Fourqurean (2003) and Fourqurean et al. (2005) have reported $\delta{ }^{13} \mathrm{C}$ values ranging between -13.5 and $-5.2 \%$ for the seagrass Thalassia testudinum in south Florida. Shifts in isotopic signature occur for organic matter in seagrass-dominated areas that are located adjacent to mangrove forests, with relatively more depleted values close to the mangrove fringe and relatively more enriched values with distance towards the bay/sea (Marguillier et al., 1997). In addition to source variations, changes in stable isotope composition of OM can also be caused by senescence, degradation and assimilation (Bouillon et al., 2007). Isotopic fractionation of $\delta{ }^{13} \mathrm{C}-\mathrm{DOM}$ as a result of photodegradation (Spencer et al., 2009) was also reported at a rate of $0.107 \mathrm{~d}^{-1}$ in $\delta{ }^{13} \mathrm{C}$ enrichment, with an observed change in $\delta{ }^{13} \mathrm{C}$-DOM from -29.2 to $-26.1 \%$ after a two months exposure period. Approximately $14-43 \%$ of DOM could be 
mineralized by photobleaching resulting in the enrichment of in $\delta^{13} \mathrm{C}$ values (Lalonde et al., 2014). While such isotopic fractionations during early diagenesis need to be considered, these changes are less significant when compared with the distinct differences between seagrass and freshwater marsh/mangrove OM sources (-10.4 to $-7.2 \%$ vs. -29 to $-25 \%$ respectively). Therefore, in this study, we assume that DOM source is the predominant control on the stable isotope signature. Thus, while stable carbon isotopes and optical properties may be very useful to elucidate spatial and temporal variations in DOM source, specific contributions to the DOM pool can be estimated through simple stable carbon isotope-based mass balance calculations. In addition, the combined use of EEM-PARAFAC and $\delta^{13} \mathrm{C}$ for DOM dynamics studies is highly promising, and has successfully been applied only recently (Osburn and Stedmon, 2011; Cawley et al., 2012).

Seagrass communities are considered a significant source of DOM to the global continental margin benthic DOC flux (Maher and Eyre, 2010; 2011). Therefore, assessing the strengths of these DOM sources is essential in constraining the global estuarine $\mathrm{C}$ budget. In addition, seagrass is a critical ecological component and drives not only water quality but also fisheries and associated tourism. Massive seagrass die-offs over the past decades have been an indication of the environmental stress that urban development and associated water use has had on such ecosystems (e.g. Robblee et al., 1991). In this respect, the Comprehensive Everglades Restoration Plan (CERP) intends to enhance freshwater delivery to re-establish water quality, and in particular salinity gradients in FB. The potential consequences of this enhanced water delivery and associate DOM export to the FB ecosystem is not well understood, and studies aimed at constraining 
carbon budgets under pre-restoration conditions are needed to better predict ecological and biogeochemical consequences of CERP. This work aims to contribute to this information need and to constrain carbon budgets in seagrass-dominated coastal bays. An additional objective of this study is to cross-validate quantitative ${ }^{13} \mathrm{C}$ mixing models with semi-quantitative EEM-PARAFAC indicators of source to reduce the degree of uncertainty in constraining carbon budgets in estuaries.

\subsection{Experimental}

\subsubsection{Sample collection and study area}

Surface water samples were collected from 15 stations (Fig.2.1) in June 2011 (early wet season), November 2011 (late wet season) and April 2012 (dry season). These sites represent a subset of the 28 sites spatially covering different regions (FB East - FBE, FB West - FBW and FB Central - FBC) previously determined to be statistically different in terms of DOM characteristics (Maie et al., 2012). Site descriptions given in Table 2.1 are based on long-term water quality monitoring conducted by the South Environmental Research Center (SERC) as previously reported by Boyer et al., (1997). A volume of 60 $\mathrm{ml}$ surface water samples were collected in pre-cleaned, brown polyethylene bottles (Nalgene) and filtered in the field using pre-combusted $25 \mathrm{~mm}$ glass fiber filters $(0.7$ $\mu \mathrm{m}$, Whatman GF/F) and placed on ice for transport to the laboratory. Filtered samples were stored in a refrigerator at $4^{\circ} \mathrm{C}$ until analysis. The resulting wet filters were stored in $1.5 \mathrm{~mL}$ of $90 \%$ acetone/water in $1.8 \mathrm{~mL}$ plastic centrifuge tubes for chlorophyll $\alpha(\mathrm{Chl} \alpha)$ analysis (Boyer et al.,1997). Field measurements of salinity and temperature were collected with a YSI meter just below the water surface (approximately $0.2 \mathrm{~m}$ depth). 


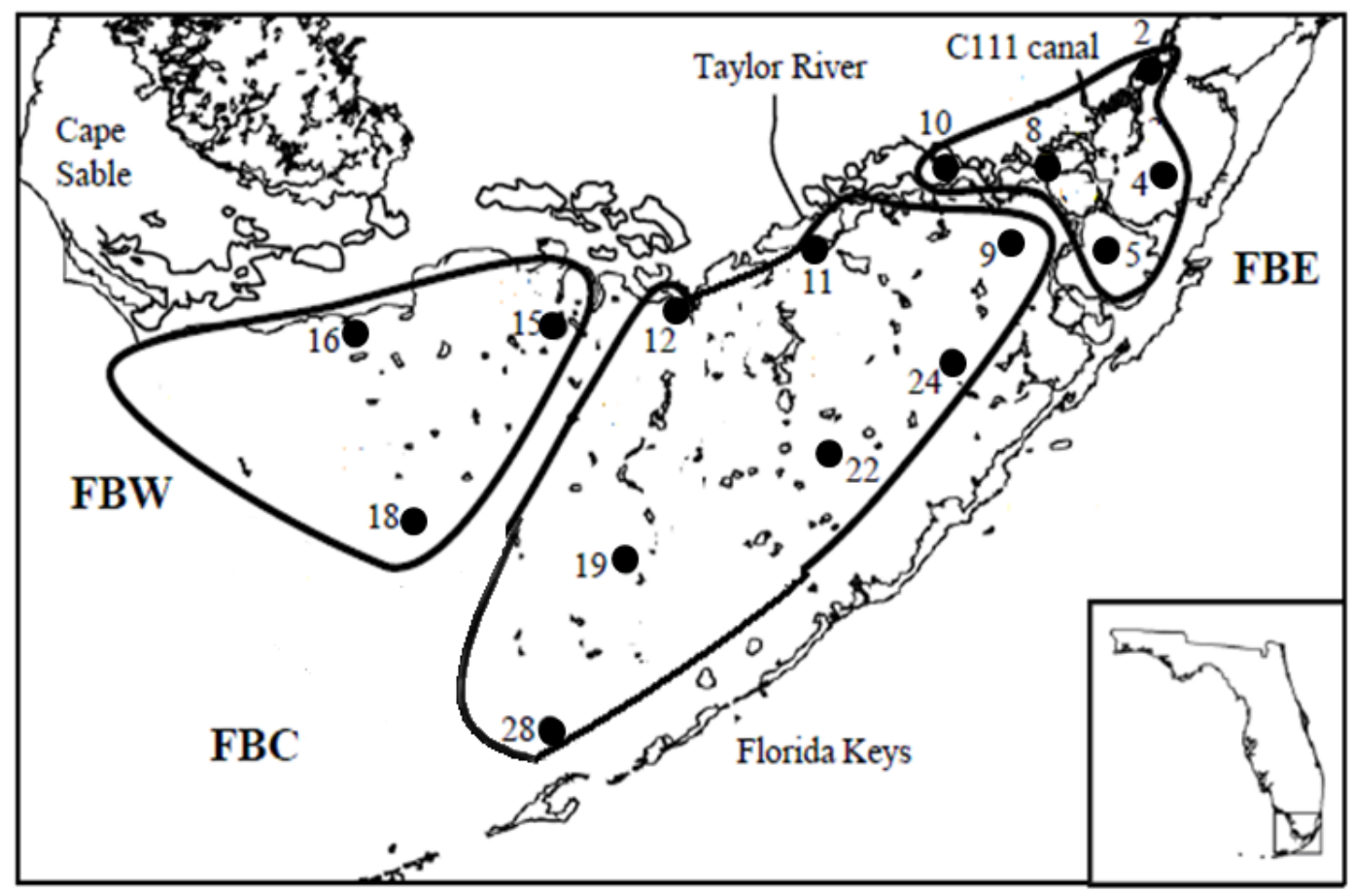

Figure 2.1 Sample sites of study region in Florida Bay indicating regions with statistically similar DOM composition. FBW=Florida Bay West; FBC= Florida Bay Center; FBE= Florida Bay East

\subsubsection{DOC concentration determinations}

DOC concentration was measured by high-temperature catalytic combustion using a Shimadzu TOC-5000A analyzer. Samples were acidified with $3 \mathrm{M} \mathrm{HCl}$ and purged with $\mathrm{CO}_{2}$-free air to remove inorganic $\mathrm{C}$ prior to analysis. Standards used for preparing calibration curves were potassium hydrogen phthalate (KHP) diluted to a concentration series of 2ppm, 5ppm, 20ppm and 50ppm. Reagent water was injected as a blank. The analytical precision was calculated based on replicates of KHP standards and estimated as $\pm 0.3 \mathrm{ppm}$. 
Table 2.1 Description of sample sites. Site information was obtained from long-term water quality monitoring program.

\begin{tabular}{|c|c|c|c|}
\hline Region & Sample site & Geographical range & Station description \\
\hline FBE & $2,4,5,8,10$ & $\begin{array}{l}\mathrm{N} 25^{\circ} 13.472 \text { to } \\
\mathrm{N} 25^{\circ} 17.017 \\
\mathrm{~W} 80^{\circ} 23.294 \text { to } \\
\mathrm{W} 80^{\circ} 32.206\end{array}$ & $\begin{array}{l}\text { wide salinity range }(0.2- \\
53.0 \%) \text {; low TP; freshwater } \\
\text { input from the } \\
\text { Everglades,C } 111 \text {; } \\
\text { low water exchange; long } \\
\text { residence time }\end{array}$ \\
\hline FBC & $9,11,12,19,22,24,28$ & $\begin{array}{l}\mathrm{N} 25^{\circ} 10.504 \text { to } \\
\mathrm{N} 25^{\circ} 52.105 \\
\mathrm{~W} 80^{\circ} 29.494 \text { to } \\
\mathrm{W} 80^{\circ} 48.352\end{array}$ & $\begin{array}{l}\text { seasonally hypersaline; long } \\
\text { residence time; } \\
\text { limited water circulation; } \\
\text { freshwater from Taylor river; }\end{array}$ \\
\hline FBW & $15,16,18$ & $\begin{array}{l}\mathrm{N} 25^{\circ} 07.070 \text { to } \\
\mathrm{N} 25^{\circ} 07.3 \\
\mathrm{~W} 80^{\circ} 56.37 \mathrm{~W} 80^{\circ} 54.028\end{array}$ & $\begin{array}{l}\text { median salinity range; SW } \\
\text { Everglades an important } \\
\text { freshwater source; high TP; } \\
\text { tidal influence; Water } \\
\text { exchange with Gulf of } \\
\text { Mexico }\end{array}$ \\
\hline
\end{tabular}

* All site information is from Boyer et al., 1997 and Maie.et al., 2010

\subsubsection{EEM-PARAFAC}

EEMs were measured using a Horiba Jovin Yvon SPEX Fluoromax-3

spectrofluorometer. The EEM method for the FCE samples was based on forty-four emissions scans, acquired at excitation wavelength $\left(\lambda_{\text {ex }}\right)$ between 240 and $455 \mathrm{~nm}$ at an increment of $5 \mathrm{~nm}$ (Coble, 1996). The emission wavelengths were scanned from 250 to $705 \mathrm{~nm}$ at increments of $2 \mathrm{~nm}$. The fluorescence signal was acquired in the ratio mode $(\mathrm{S} / \mathrm{R})$ to eliminate potential fluctuations of the Xe lamp with an integration time of $0.25 \mathrm{~s}$ and reported in quinine sulfate units (QSU). The absorbance at $254 \mathrm{~nm}\left(\mathrm{a}_{254}\right)$ was determined using a Varian Cary 50 Bio spectrophotometer with a $1 \mathrm{~cm}$ quartz cuvette 
scanning from $200 \mathrm{~nm}$ to $800 \mathrm{~nm}$. Inner filter correction was performed by using the UVVis data (McKnight et al., 2001). The Raman peak area of Mili-Q water was used for the correction of daily fluorescence intensity variations. The built-in Ex and Em correction factors were used for instrument bias correction. Mili-Q water was measured in a 1-cm quartz cuvette and used for blank correction.

Parallel factor analysis (PARAFAC) was conducted by MATLAB 7.0.4 using the DOMFluor toolbox (Stedmon and Bro, 2008) based on an alternating least square (ALS) algorithm (Bro, 1997). This study was conducted by fitting the corrected EEMs of FB stations to the established Florida Coastal Everglades PARAFAC model (Yamashita et al., 2010). Briefly, this PARAFAC model was based on a large number of samples ( $\mathrm{n}=1394$ ) within the Florida Coastal Everglades including a large number of samples from FB. Eight EEM-PARAFAC components were obtained after PARAFAC modeling (six humic-like components and two protein-like components) and validated by split-half validation (Stedmon and Bro, 2008). Detailed descriptions of these PARAFAC components have been provided elsewhere (Yamashita et al., 2010; Chen et al., 2013). The basic characteristics of each individual PARAFAC component are listed in Table 2.2 . 
Table 2.2 Description of the eight PARAFAC components in the Everglades' model and regression between individual PARAFAC components with $\delta^{13} \mathrm{C}$

\begin{tabular}{lccc}
\hline & Ex $(\mathrm{nm})$ & $\begin{array}{c}\text { Em } \\
(\mathrm{nm})\end{array}$ & Description \\
\hline $\mathrm{C} 1$ & $<260(345)$ & 462 & Ubiquitous humic-like \\
$\mathrm{C} 2$ & $<260$ & 454 & Terrestrial humic-like (agricultural land derived) \\
$\mathrm{C} 3$ & $<260(305)$ & 416 & Fulvic acid-type \\
$\mathrm{C} 4$ & $<260(305)$ & 376 & Microbial humic-like \\
$\mathrm{C} 5$ & $275(405)$ & $>500$ & Humic acid-type \\
$\mathrm{C} 6$ & 325 & 406 & Photo-labile humic-like \\
$\mathrm{C} 7$ & 275 & 326 & Tyrosine-like \\
$\mathrm{C} 8$ & 300 & 342 & Tryptophan-like \\
Established PARAFAC model for great Everglades, published by Yamashita et \\
al.,(2010); \\
Chen et al.,2013 & \\
\hline
\end{tabular}

\subsection{4 $\delta^{13}$ C analysis}

Measurements of $\delta^{13} \mathrm{C}$ were performed on an Aurora1030 wet oxidation TOC analyzer (OI Analytical) coupled with a G1111-i $\mathrm{CO}_{2}$ isotope cavity ring-down spectrometer (CRDS, Picarro Instruments). CRDS-based methods have been recently applied for the measurement of $\delta^{2} \mathrm{H}$ and $\delta^{18} \mathrm{O}$ in waters (Munksgaard et al., 2011), $\delta^{13} \mathrm{C}$ in gas-phase $\mathrm{CO}_{2}$ (Berryman et al., 2011), and in direct measurements of DOC $\delta^{13} \mathrm{C}$ (Hartland et al. 2012). Here DOM samples $(1 \mathrm{ml})$ were chemically oxidized to $\mathrm{CO}_{2}$ at a temperature of $98^{\circ} \mathrm{C}$ in the presence of $15 \%$ sodium persulfate $\left(\mathrm{Na}_{2} \mathrm{~S}_{2} \mathrm{O}_{8}\right)$. Dissolved inorganic carbon (DIC) was removed with $10 \%$ phosphoric acid $\left(\mathrm{H}_{3} \mathrm{PO}_{4}\right)$ and sparged using $\mathrm{N}_{2}$ gas. $\mathrm{CO}_{2}$ was generated and detected by non-dispersive infrared absorption (NDIR) for the measurement of TOC. $\mathrm{CO}_{2}$ was collected and accumulated in a gas-tight bag and then pulsed into the CRDS for the isotopic measurement. For different isotopic ranges, calibration was based on two external standards of potassium hydrogen phthalate (KHP -29.8\%, OI-Analytical) and glutamine (-11.45\%, Fisher) at a concentration range 
of 0-25 ppm. The standards were prepared in synthetic sea water to match the sample matrix. The isotope values of the standards were determined using elemental analyzer isotope ratio mass spectrometer (EA-IRMS). Analytical precision based on replicated standards is $\pm 0.41 \%$.

The detection limit for the CRDS system was determined to be 4ppm under the conditions of these analyses. Since DOC concentration for some sampling sites in FB were below the detection limit for the CRDS system, these samples were preconcentrated prior to $\delta^{13} \mathrm{C}$ analysis using ultrafiltration (Benner et al., 1992). Briefly, 2L surface water was ultrafiltered through 1000-dalton Millipore tangential flow membrane filters using a Pellicon-2 mini filter as ultrafiltration device, and the filtrates were used for $\delta^{13} \mathrm{C}$ analysis. The recovery was calculated to be $\sim 53 \%$ of the total DOM.

Ultrafiltration was applied only to increase DOC by $\sim 2$ times the initial concentration. In order to determine whether ultrafiltration caused any difference on $\delta^{13} \mathrm{C}$ values, $\delta^{13} \mathrm{C}$ was measured for both DOM (DOC $>4 \mathrm{ppm}, \mathrm{n}=12)$ and UDOM $(\mathrm{n}=12)$ samples of the same sampling sites in FB. Significant difference was found in the $\delta^{13} \mathrm{C}$ values between UDOM (Average $\delta^{13} \mathrm{C}=-19.7 \%$ ) and DOM (Average $\delta^{13} \mathrm{C}=-21.3 \%$ ) (paired t-test, $\mathrm{t}_{11}=$ $0.001, \mathrm{p}<0.05)$. The isotope differences $(-1.6 \%)$ is likely due to the OM mass difference since UDOM represents about 50\% of the bulk DOM. However, UDOM still capture the bulk features of DOM and thus the $\delta^{13} \mathrm{C}$ value reported for UDOM can be expected to be representative of the DOM isotopic signature.

\subsubsection{Statistical analysis}

PARAFAC was conducted by MATLAB 7.0.4. Spatial mapping of $\delta^{13} \mathrm{C}$ was carried out using Surfer (10.0). Boxplot (25th percentile, median and 75th percentile) 
and linear correlations $\left(\mathrm{r}^{2}\right)$ were generated using SigmaPlot 7.101 at a confidence limit of $95 \%$ using the relative abundance (\% of total fluorescence intensity) of the PARAFAC components $(\mathrm{n}=8)$ and $\delta^{13} \mathrm{C}$ values. The statistical significance of the difference observed between geographical regions and among the three sampling seasons was tested by SPSS 17.0 using ANOVA.

\subsection{Results and Discussion}

\subsubsection{Spatial and temporal variations of stable carbon isotope and optical properties of} DOM in Florida Bay

Representative EEMs for both FB DOM and a seagrass leachate are shown in Figure 2.2. Peak location and classification is based on Coble (1996). The seagrass leachate showed the presence of a significant B peak (tyrosine-like: Ex/Em 275/310 nm) and T peak (tryptophan-like: Ex/Em 275/340 nm). DOM collected in FB exhibited an abundant A peak (humic-like: Ex/Em 260/380-460 nm) elongated with an evident T peak likely related to the presence of seagrass-derived DOM, particularly in the FBC and FBW regions, which are characterized by vast seagrass meadows (Fourqurean et al., 1992). FBE as a more terrestrially influenced region did not exhibit a significant $T$ peak compared with FBE and FBW. As shown in Table 2.3 both the optical properties and stable carbon isotope values for the freshwater marsh and mangrove derived DOM were significantly different to those of the seagrass-derived DOM, with an enriched humic-like fluorescence and depleted $\delta^{13} \mathrm{C}$ values from the former. When comparing PARAFAC and isotopic composition of DOM leached from the dominant biomass species in the freshwater marsh (Sawgrass; Cladium jamaicense), mangrove fringe (red mangrove; Risophra mangle) and coastal bay (Seagrass;Thalassia testudinum), the seagrass-derived 
DOM best resembled the features of DOM in FB with the highest abundance in proteinlike fluorescence and the most enriched $\delta^{13} \mathrm{C}$ values (Table 2.3). The PARAFAC distribution of DOM in FB showed a remarkable enrichment in protein-like components (Table 2.3) compared with SW. Everglades estuaries (Shark River and Harney River) and the Gulf of Mexico, coupled with the least relative abundance of humic-like components. This is in agreement with previous findings (Maie et al., 2005; 2006 a,b) reporting that DOM in FB featured different characteristics compared to the Everglades. FB showed the widest range (Table 2.3), and on average the most enriched isotopic values ($16.9 \pm 0.56 \%$ ) when compared with other regions in the Everglades, suggesting a dynamic mixing of DOM sources from the freshwater Everglades and fringe mangroves with DOM derived from the seagrass community in the bay.

The variability of $\delta^{13} \mathrm{C}$-DOM on both temporal and spatial scales was assessed using three sampling sets from samples collected during the early wet season (June 2011), late wet season (November 2011) and the dry season (April 2012). Sampling was designed spatially and seasonally based on previous reports (Maie et al., 2012) where spatial and seasonal DOM dynamics in FB were suggested to be driven by a combination of hydrology, or freshwater runoff from the Everglades, and primary productivity, particularly of the seagrass communities. As such sampling stations previously categorized as having statistically different DOM characteristics were selected from areas defined as FB East (FBE), FB West (FBW) and FB Central (FBC). The spatial distribution of the $\delta^{13} \mathrm{C}$ values throughout $\mathrm{FB}$ showed very similar general distribution patterns during the three sampling periods, with the most enriched values observed in the southern section of FBC (Figure 2.3). 

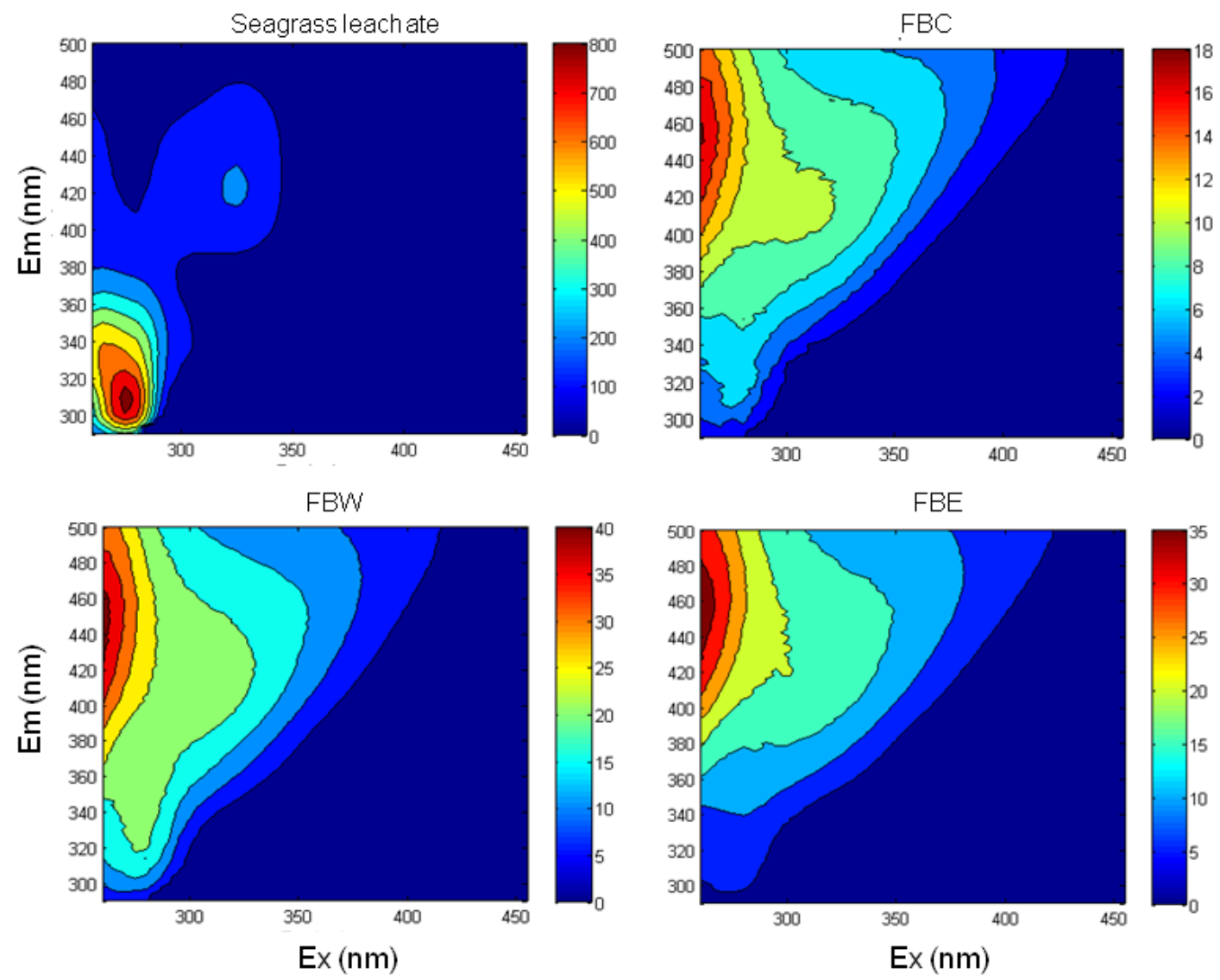

Figure 2.2 Representative EEMs of FB surface water DOM and seagrass leachate 
Table 2.3 Comparative table of DOM characteristics (relative abundance of humic-like components, protein-like components and $\delta^{13} \mathrm{C}$ ) in different locations

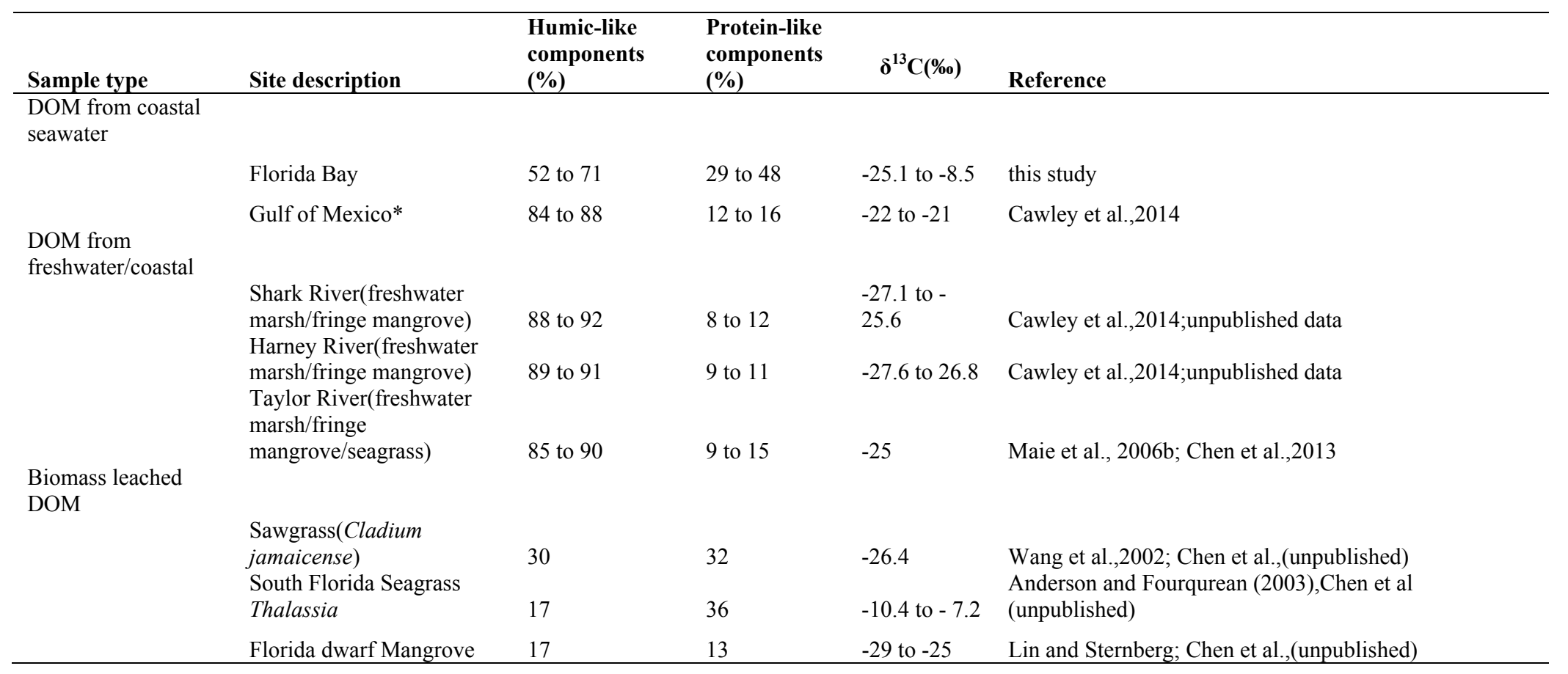

Note: * Ponce de Leon Bay 

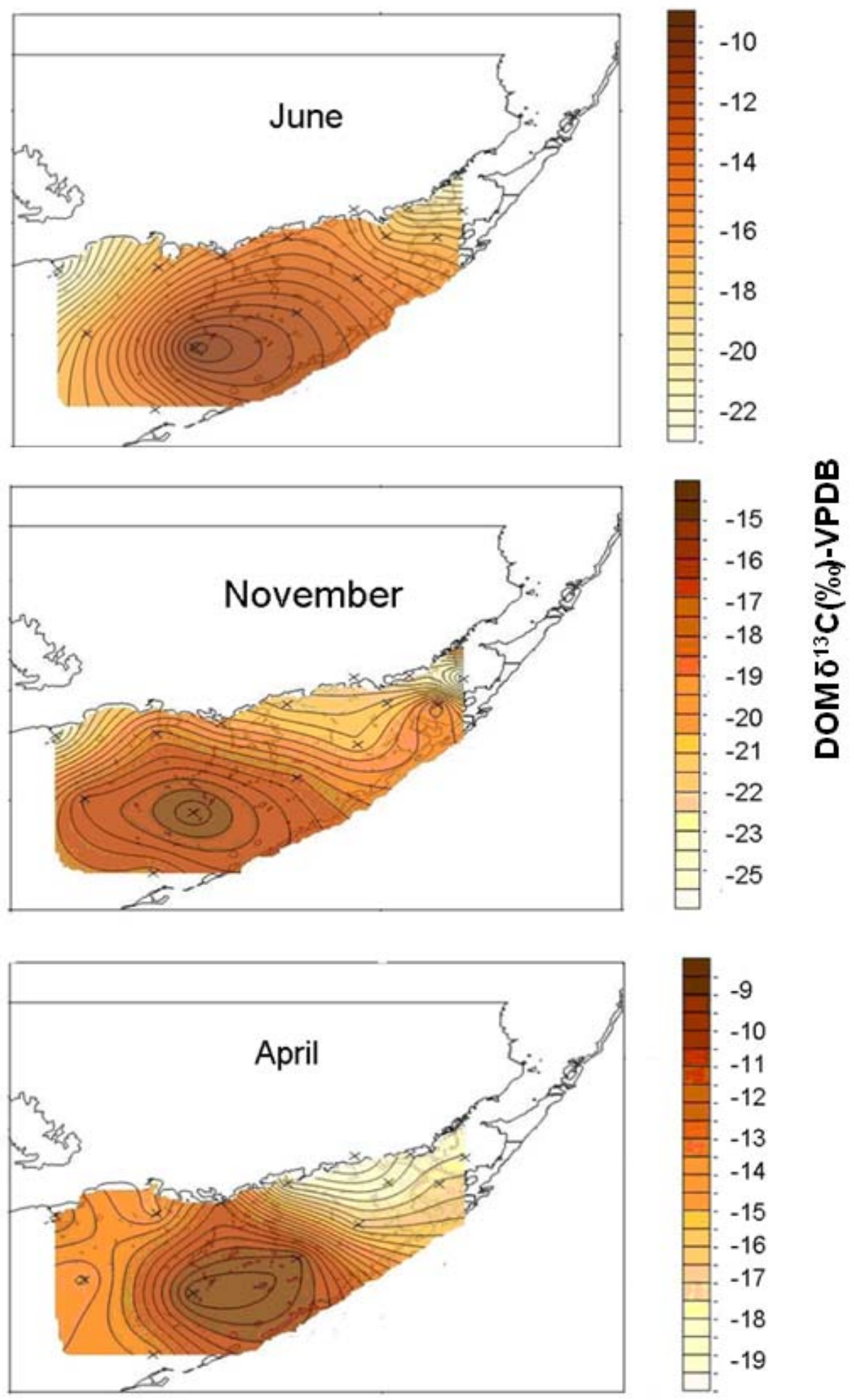

Figure 2.3 Spatial distribution of $\delta^{13} \mathrm{C}$-DOM during early wet season (June), late wet season (November) and dry season (April) 
The enriched $\delta^{13} \mathrm{C}$ values $(-15.4 \% \mathrm{~m} \pm 1.6 \%$ ) for $\mathrm{FBC}$ suggest less direct freshwater and mangrove-derived DOM sources (depleted $\delta^{13} \mathrm{C}$ ), and instead featuring isotopically enriched values likely derived from autochthonous seagrass community sources. This is in agreement with similar distribution plots reported for protein-like fluorescence, showing highest abundance in the FBC region (Maie et al., 2012). Considering that $\delta^{13} \mathrm{C}$ values determined for the seagrass Thalassia testudinum in FB showed a range from 13.5 and $-5.2 \% 0$ (Anderson and Fourqurean, 2003; Fourqurean et al., 2005), the isotopically enriched signal of the DOM in FB suggests that the benthic communities indeed play an important role in the local C-budget. $\mathrm{FBC}$ and in particular the $\mathrm{FBC}$-west region is characterized by vast seagrass meadows (Fourqurean et al., 1992), has longer residence times compared with FBE and FBW (Boyer et al.,1997), and is further distanced from the mangrove ecotone. Consequently this area is prone to the accumulation of seagrass-derived DOM (e.g. station $28 ;-15.3 \pm 1.4 \%$ ), which is produced year-round, but has been suggested as being particularly important during the early wet season (Fourqurean et al., 1992; Anderson and Fourqurean, 2003; Maie et al., 2012).

In contrast to $\mathrm{FBC}$, the $\mathrm{FBE}$ region showed the most depleted $\delta^{13} \mathrm{C}$ values $(-20.8 \%$ to $-18.4 \%$ ) likely as a result of the influence of significant DOM-derived from the Everglades exported through the $\mathrm{C} 111$ canal, draining the agricultural areas (Wang et al., 2002) and the upper watershed of the greater Everglades. FBW showed a year-round average of $-16.8 \% \pm \pm-1.7 \%$ with the most enriched values during the dry season (13.4\%o). This observation is in agreement with the reported increasing gradient of seagrass density towards the western FB (Fourqurean et al., 1992). Overall, allochtonous DOM from freshwater marsh, agricultural canal runoff (Stern et al., 2007; Wang et al., 
2002), and export from fringe mangrove swamps (Jaffé et al., 2004; Cawley et al., 2014) mixes in the FB estuary with seagrass-derived DOM, particularly in the FBE and FBW regions. In contrast, DOM sources in FBC seem mainly seagrass dominated.

The isotopic signature of DOM in Florida Bay also showed seasonal variations where $\mathrm{C}$ isotope values ranged from $-22.8 \%$ to $-9.7 \%$ in July (early wet season), $-25.2 \%$ o to $-14.5 \%$ in November (late wet season), and were most enriched with a range from $19.9 \%$ to $-8.5 \%$ during April (dry season). During the dry season, the effect of freshwater inputs from the Everglades is minor due to low hydrological head, lighter wind-driven mixing and higher evaporation (Boyer et al., 1997). Thus, the major impact on DOM composition is from the local seagrass-community, and is a function of the combined effects of primary productivity and senescence of seagrass detritus. Both processes have been suggested important in seagrass-dominated estuarine DOM production (Stabenau et al., 2004; Cawley et al., 2012). In contrast, during the late wet season (November) $\delta^{13} \mathrm{C}$ values were significantly more depleted, as this time period coincides with the most significant freshwater discharge from the Everglades, and associated terrestrial higher plant (C-3) derived DOM (Maie et al., 2012). As to the early wet season (July), the $\delta^{13} \mathrm{C}$ values were also relatively more depleted compared to the dry season, but more enriched compared to the late wet season. This observation is in agreement with previous studies suggesting that seagrass primary productivity peaks during June-July (Maie et al., 2012; Fourqurean et al., 2012), a process known to contribute significantly to the DOM pool (Ziegler and Benner, 2000; Apostolaki et al., 2010). The $\delta^{13} \mathrm{C}$ enrichment during the dry season compared to the early wet season may 
be the result of higher seagrass litter degradation while hypersaline conditions in the bay prevail.

In addition to DOM- $\delta^{13} \mathrm{C}$, the fluorescence carried source signatures as well. To better evaluate the EEM-PARAFAC data variations, principal component analysis (PCA) was conducted based on the relative abundance of PARAFAC components (Figure 2.4). PC1 accounts for $58 \%$ and PC2 for $16 \%$ of variability in the data. Loadings of the 8 PARAFAC components were distinctly separated along PC1 with the protein-like components (C7 and $\mathrm{C} 8)$ and the microbial humic-like components ( $\mathrm{C} 4$ and $\mathrm{C} 6)$ located on the positive $\mathrm{PC} 1$ scale. In contrast, the terrestrial humic-like components $(\mathrm{C} 1, \mathrm{C} 3$ and C5) were located on the negative PC1 scale, suggesting that PC1 is representative of DOM source, with microbial/seagrass sources featuring more positive PC1 values compared to more terrestrially influences sites featuring more negative PC1 values. It is unclear why $\mathrm{C} 2$ is located on a positive PC1 scale, as this terrestrial humic-like component is mainly derived from agricultural soils (Yamashita et al., 2010) and as such observed to act conservatively in the estuarine zone (Cawley et al., 2014). The general observed trend along PC1 from terrestrial (Taylor Slough) to FBW and FBE, and lastly to FBC seems to agree with the previously discussed source strengths for these areas, showing an increasing contribution of seagrass-derived DOM along this gradient.

While PC2 only explains $16 \%$ of the variability in the dataset, similar to previous reports in the Everglades ecosystem (Maie et al., 2012; Chen et al., 2013; Cawley et al., 2014), PC2 seems to be indicative of DOM reactivity, with negative PC2 values suggesting inputs of 'fresh', microbial/seagrass-derived materials (enriched in C6, C7 and C8), while positive PC2 values suggest more photodegraded DOM and degraded canal- 
derived materials (i.e. enriched in C2; Chen et al., 2010; Yamashita et al., 2010).

However, the bulk of the samples fell within a quite narrow range of PC2. As such, the PCA data suggests that the variability in the data is mainly driven by source differences
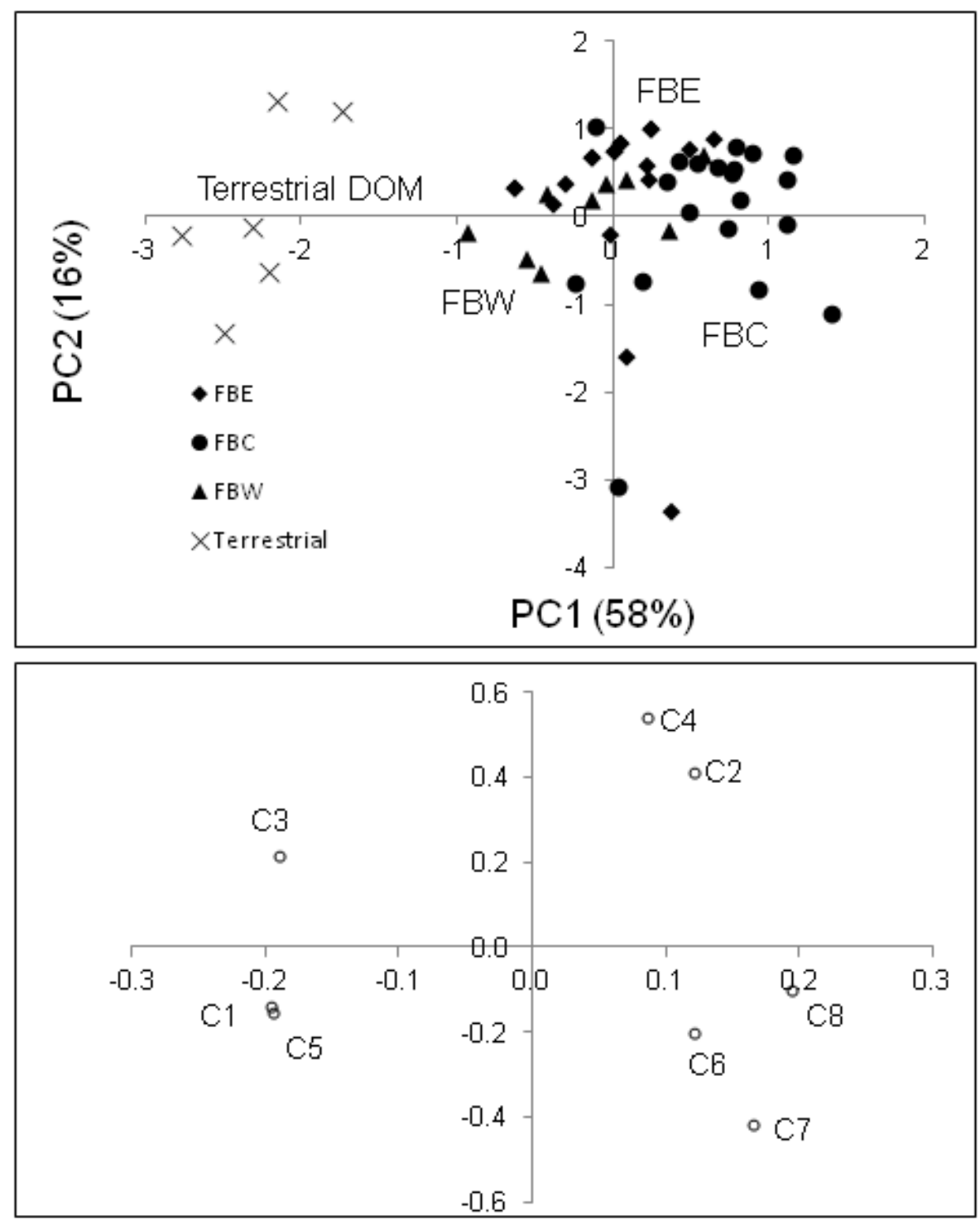

Figure.2.4 Principal component analysis (PCA) for plant leachate, FB and terrestrial DOM with loading plots based on the relative abundance of the eight PARAFAC components 
In an attempt to validate the previously applied optical proxies for DOM source assessments in $\mathrm{FB}$, the distribution of PARAFAC components was compared with the corresponding stable isotope values. $\mathrm{FBC}$ showed significantly lower $(\mathrm{p}<0.05)$ abundance of humic-like fluorescence than FBE and FBW (Fig.2.5a), in agreement with the fact that this region was dominated by isotopically enriched, seagrass-derived DOM. With regards to the protein-like fluorescence patterns, these coincide well with the $\delta^{13} \mathrm{C}$ distribution, suggesting that significantly higher relative abundance of protein-like DOM in FBC is indeed derived from seagrass inputs. In most instances, the quantitative values for the Fmax-normalized protein-like fluorescence values were not statistically different seasonally ( $p>0.05$ ), except for a broad range in values observed during the late wet season for FBE and FBW and during the early wet season for FBW (Fig. 2.5b). However, while the overall abundance of the protein-like fluorescence did not exhibit significant differences between FBE and FBW ( $p>0.05$ ), it was higher in FBC. Since protein-like components are nearly ubiquitous in samples from both seawater and freshwater $\mathrm{Wu}$ and Tanoue, 2001), the lack of variability in the Fmax normalized protein-like fluorescence in different regions particularly for FBE and FBW suggests that the abundance of proteinlike components in FB is not controlled by hydrological change and Everglades DOM input, but mostly by autochthonous, seagrass sources.

To cross-validate quantitative $\delta{ }^{13} \mathrm{C}$ values with semi-quantitative EEMPARAFAC indicators of source, linear correlations between individual PARAFAC components and $\delta^{13} \mathrm{C}$ were tested. While none of the individual PARAFAC components provided a significant linear correlation with the $\delta^{13} \mathrm{C}$ values $\left(\mathrm{r}^{2}<0.3, \mathrm{p}>0.05\right)$, significant overall correlations between the $\delta^{13} \mathrm{C}$ and the combined humic-like (C1, C2, C3 and C5) 
and the combined protein-like components (C7 and C8) were observed $\left(r^{2}=0.40\right.$ and $0.33, \mathrm{p}<0.01)$. The combined humic-like components, which excluded the microbial components C4 and C6 (reported as photosensitive; Chen and Jaffé, 2014), correlated negatively with $\delta^{13} \mathrm{C}$. In contrast, the combined protein-like components showed the opposite trend (Fig. 2.6). Although statistically significant $(\mathrm{p}<0.01)$, the correlation coefficients were reasonably low as a result of scatter in the dataset. This scatter could be the result of contributions of CDOM from seagrass litter decomposition to the humic-like DOM (Stabenau et al., 2004; Cawley et al., 2012). Variations in photo-degradation of aromatic DOM components (Ziegler and Benner, 1999; Chin et al., 1994) could also contribute to this scatter. In addition, the contribution of polyphenols to the protein-like fluorescence (Maie et al., 2006b; 2007) could affect the correlation between this fluorescence and the $\delta{ }^{13} \mathrm{C}$. While the effect of photodegradation on the DOM $\delta{ }^{13} \mathrm{C}$ values has been discussed above, contributions to the humic-like fluorescence by seagrass detritus and/or the contributions of seagrass-derived polyphenols to the protein-like fluorescence, can affect the fluorescence signature, but should not significantly impact source assignments based on the $\delta{ }^{13} \mathrm{C}$ values. As such, while the optical proxies are applicable to determine the influence of hydrology and primary productivity on DOM dynamics in the bay (Maie et al., 2012) they are not suggested to be used as means to quantify end-member contributions through simple mixing models in this environment. 

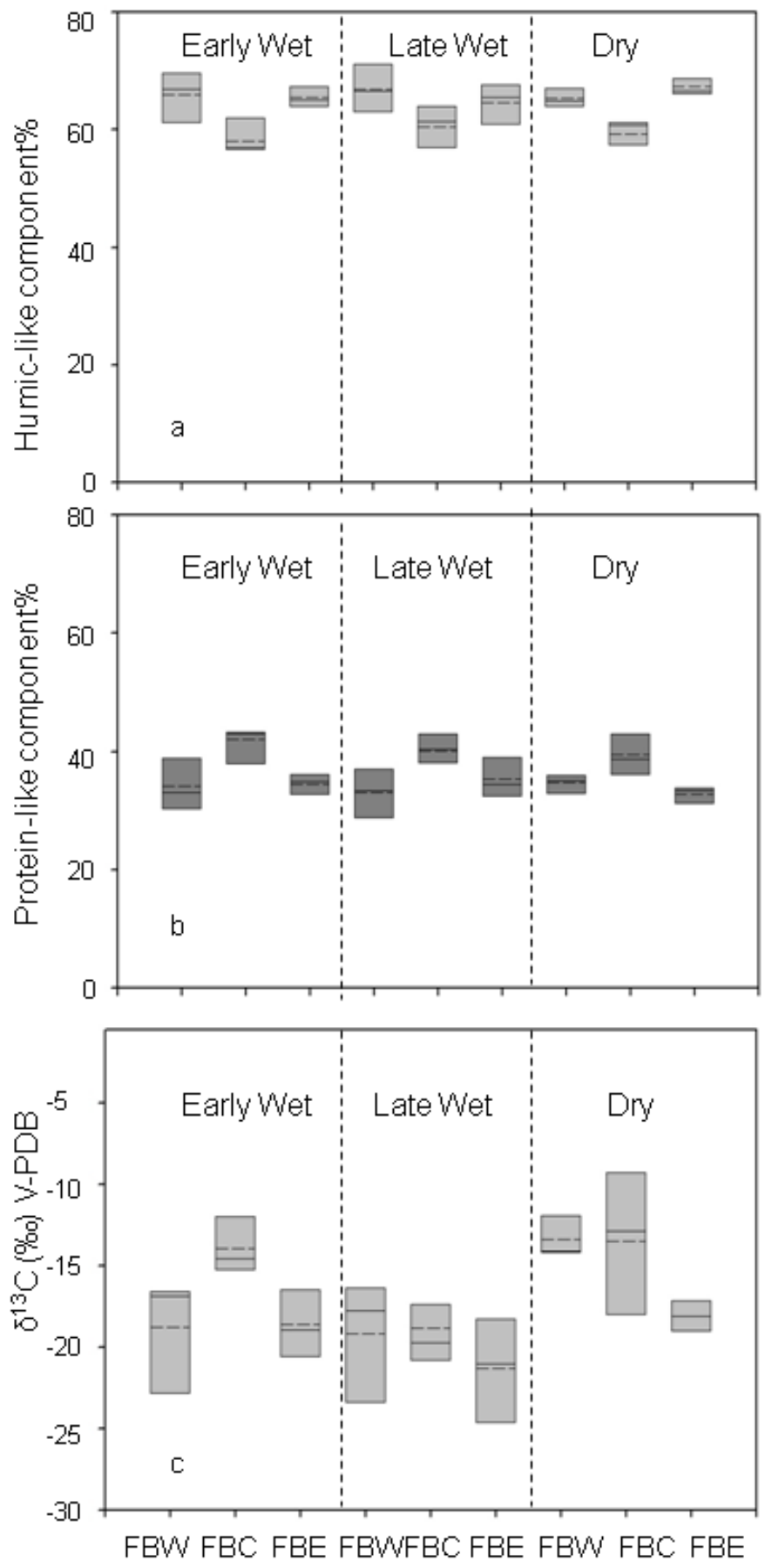

Figure 2.5 Boxplot of (a) relative abundance of humic-like substances and (b) relative abundance of protein-like (c) DOC $\delta^{13} \mathrm{C}$ values in FBE, FBC and FBW during the three sampling seasons 

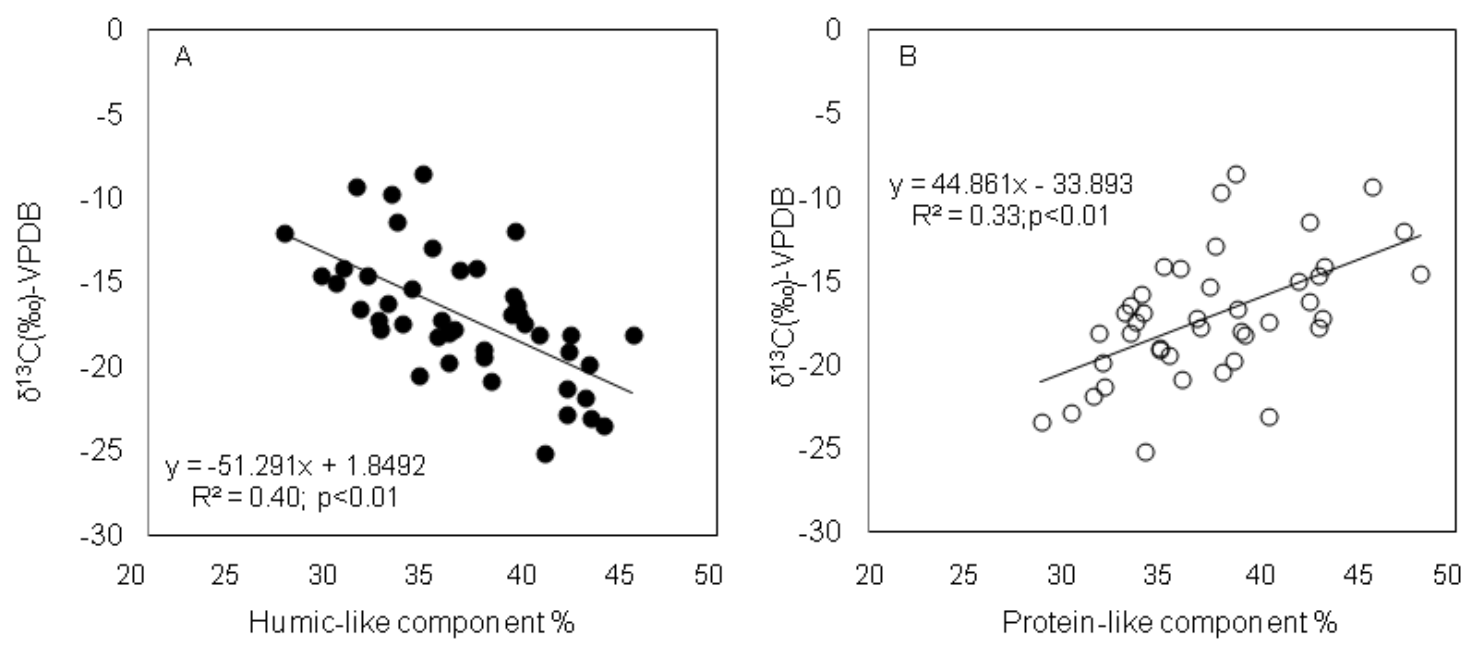

Figure 2.6 Correlation between DOC stable carbon isotope values $\delta^{13} \mathrm{C}$ and the relative abundance of EEM-PARAFAC components: Humic-like components $\%=$ $(\mathrm{C} 1+\mathrm{C} 2+\mathrm{C} 3+\mathrm{C} 5) \%$; Protein-like components $\%=(\mathrm{C} 7+\mathrm{C} 8) \%$ for samples collected during early wet season (June 2011), late wet season (November 2011) and dry season (April 2012) combined

\subsubsection{Quantification of seagrass-derived DOM in Florida Bay}

The positive correlation between protein-like fluorescence and $\delta^{13} \mathrm{C}$ values suggest that indeed this fluorescence may primarily be derived from seagrasses, but protein-like fluorescence has also been assigned to planktonic sources (Romera-Castillo et al., 2010). While chlorophyll concentration is often used as the indicator of phytoplankton biomass (Bianchi, 2007) and phytoplankton has been suggested to generate FDOM (Rochelle-Newall and Fisher, 2002; Romera-Castillo et al., 2010), the lack of correlation between chlorophyll concentration and protein-like fluorescence $\left(\mathrm{R}^{2}=\right.$ $0.16, \mathrm{p}<0.05)$ suggests that free-floating phytoplankton does not contribute significantly to the FDOM pool in FB. Although, seagrass communities are known to feature extensive epiphytic growth (Moncreiff et al., 1992; 2001), and these could potentially contribute to the production of protein-like DOM, seagrass epiphytes have been shown to have $\delta^{13} \mathrm{C}$ 
values similar to seagrass (Williams et al., 2009). As such, the calculations shown below are based on the assumption that free-floating phytoplankton-derived DOM (not epiphytic plankton) does not make a significant contribution to the DOM pool in Florida Bay, simplifying the multi non-point sources mixing model to a simple, two end-member (Everglades marsh/mangrove vs. seagrass) approach.

The mass balance equation for the two end-member mixing model is shown below:

$\delta_{\mathrm{m}}=\mathrm{f}_{\mathrm{a}}\left(\delta_{\text {mangrove }}+\delta_{\text {terrestrial }}\right)+\mathrm{f}_{\mathrm{b}} \delta_{\text {seagrass }}$

$1=f_{a}+f_{b}$

where $\mathrm{f}$ is the fraction of end-member contributions, $\delta_{\text {mangrove }}, \delta_{\text {terrestrial }}$ and $\delta_{\text {seagrass }}$ are the $\delta^{13} \mathrm{C}$ value of each individual source, and $\delta \mathrm{m}$ is the $\delta^{13} \mathrm{C}$ value of the actual DOM composite in each sample. While free-floating phytoplankton is assumed to be a negligible contributor to the DOM pool (see above), and terrestrial (Everglades freshwater marsh) and mangrove sources were combined into one allochthonous contributor (since the $\delta^{13} \mathrm{C}$ value of these two sources have very similar values), the mixing model applied was a simple two end member mixing model. End-member $\delta^{13} \mathrm{C}$ values for the OM sources from Everglades' terrestrial area was obtained by averaging the $\delta^{13} \mathrm{C}$ value of soils, surface sediments and major plants reported in the literature (ca. $27.8 \pm 1.5 \%$; Wang et al., 2002). The $\delta^{13} \mathrm{C}$ value for mangrove $\mathrm{OM}(-26.7 \%$ $\pm 0.3 \%$ ) was obtained from previous reports on the Florida fringe coastal mangrove community (Fleming et al., 1990). The estimated average of the combined $\delta^{13} \mathrm{C}$ value of terrestrial and mangrove sources, without considering the weighting of species coverage, resulted in 
an isotopic value of $-26.8 \pm 0.4 \%$. Seagrass isotope values reported for South Florida coastal zones (Anderson and Fourqurean 2003; Fourqurean et al., 1995,2005) were averaged of seagrass Thalassia testudium samples collected at the permanent monitoring stations across the subtropical coastal marine areas in Florida Keys (see detail in Anderson and Fourqurean 2003) resulting in a value of $c a .-8.4 \% \pm 0.7 \%$. Average variation in seagrass- $\delta^{13} \mathrm{C}$ across Florid Keys has been reported as $1.90 \pm 0.11 \%$. This spatial variation is based on a large scale survey of over $10,0000 \mathrm{~km}^{2}$ area (Fourqurean et al.,2005). Our study region in FB is relatively small compared with the above described study area and thus the spatial variation of seagrass end-member was not considered for mixing model calculation.

Based on this simplified two end-member mixing model, and in agreement with previous reports (Stabenau et al., 2004; Maie et al., 2005), seagrass acts as the dominant source of DOM in FB during the three sampling seasons, with a maximum contribution of about $72 \%$ during the dry season for FBC and FBW, and the lowest contribution of about 33\% during the late wet season for FBE (Table 2.4). On spatial scales, the contribution of the seagrass community to the DOM pool was estimated as $\mathrm{FBC}>\mathrm{FBE}>$ FBW during the early wet season, $\mathrm{FBW}>\mathrm{FBC}>\mathrm{FBE}$ during the late wet season, and $\mathrm{FBC}=\mathrm{FBW}>\mathrm{FBE}$ during dry season. Similar regional variation were found for the PARAFAC components (Table 2.4) with FBC in general showed the highest relative abundance of protein-like components followed by FBW and FBE while humic-like components showed the opposite trend. This again suggests the coupling between seagrass contribution with the protein-like DOM in FB. On average, FBE had the lowest 
seagrass contribution. This region is strongly impacted by freshwater derived DOM through the $\mathrm{C} 111$ canal and the proximity to the mangrove fringe. In addition, $\mathrm{P}$ limitations in the NE section of the bay may reduce seagrass primary productivity in this region (Fourqurean et al., 1992). Compared with FBE, FBW has higher primary productivity during the late wet season most likely as a result of higher TP availability (Boyer et al., 1997) and is in agreement with previous studies reporting a positive correlation between seagrass-derived CDOM with areal productivity (Ziegler and Benner 1999). In fact, FBC and FBW had similar and highest seagrass contributions during the dry season when the influence of Everglades freshwater derived DOM on FBW is minimal (Maie et al., 2012). While FBC had the highest seagrass-derived DOM during the early wet season, it was again similar to FBW during the late wet season when waters draining the Everglades and fringe mangrove swamps from SW Everglades National Park have the highest impact on FBW. DOM humic-like fluorescence derived from the SW estuaries of Everglades National Park, has been suggested not only to reach FBW (Maie et al., 2012) but to reach further SW to the mid-section of the Florida Keys bay side (Yamashita et al., 2013), and as such could have an influence also in the most southern section of FBC.

On temporal scales the seagrass contributions for FBC were dry $>$ early wet $>$ late wet, FBW dry $>$ late wet $=$ early wet, and FBE dry $>$ early wet $>$ late wet. In general, the highest contribution was, as expected, during the dry season followed by the early wet season and late wet season. In agreement with this trend, the late wet season showed the lowest relative abundance of protein-like components for FBC and FBW, suggesting that the protein-like DOM is mostly controlled by seagrass primary productivity. 
Additionally, the dry season maxima may also result from longer residence times (FBC) and reduced terrestrial runoff (FBW) and enhanced degradation of seagrass litter. The lowest input from seagrass was consistently observed during the late wet season. 
Table 2.4 Summary of regional and seasonal DOC, humic-like and protein-like PARAFAC components' relative abundance and DOC $\delta^{13} \mathrm{C}$ values. Two end-member mixing model estimated seagrass contributions (\%) to DOC pool are indicated.

\begin{tabular}{lllcccc}
\hline Region & Season & DOC(ppm) & $\begin{array}{c}\text { Humic-like } \\
\text { component (\%) }\end{array}$ & $\begin{array}{c}\text { Protein-like } \\
\text { component (\%) }\end{array}$ & $\boldsymbol{\delta}^{\mathbf{1 3}} \mathbf{C}(\%)$ & proportion (\%) \\
\hline FBE & early wet & $7.16 \pm 1.25$ & $39 \pm 1$ & $35 \pm 1$ & $-18.4 \pm 1.3$ & $46(37-57)$ \\
& late wet & $5.80 \pm 0.62$ & $42 \pm 1$ & $34 \pm 1$ & $-20.8 \pm 2.2$ & $33(24-44)$ \\
& dry & $4.83 \pm 2.00$ & $42 \pm 1$ & $33 \pm 1$ & $-17.3 \pm 1.1$ & $52(43-63)$ \\
FBC & early wet & $6.14 \pm 0.58$ & $31 \pm 1$ & $43 \pm 2$ & $-13.9 \pm 1.1$ & $70(62-81)$ \\
& late wet & $6.01 \pm 0.59$ & $35 \pm 1$ & $39 \pm 2$ & $-18.9 \pm 1.1$ & $43(34-54)$ \\
FBW & dry & $7.00 \pm 2.32$ & $33 \pm 0$ & $41 \pm 1$ & $-13.6 \pm 0.5$ & $72(64-83)$ \\
& early wet & $7.81 \pm 0.85$ & $37 \pm 3$ & $34 \pm 2$ & $-18.8 \pm 2.0$ & $43(35-55)$ \\
& late wet & $5.63 \pm 0.46$ & $40 \pm 2$ & $33 \pm 1$ & $-17.8 \pm 1.0$ & $49(40-60)$ \\
& dry & $6.27 \pm 0.86$ & $38 \pm 1$ & $35 \pm 1$ & $-13.4 \pm 0.7$ & $72(65-84)$ \\
\hline
\end{tabular}

*: Seagrass proportion is reported as average $\%$ and $\%$ range is shown in parenthesis 


\subsection{Conclusions}

DOM dynamics in tropical and subtropical estuaries and coastal bays can be complex on spatial and temporal scales due to the combination of contributions from fringe mangrove, coastal wetlands, plankton and seagrass meadows. An accurate quantification of DOM pools, fluxes and their controls is essential in understanding estuarine biogeochemical cycling, providing critical information needed in the assessment of carbon budgets (Houghton, 2007), and in estimating relationships between carbon reservoirs and climate change (Hopkinson and Vallino, 2005). In this study the combination of $\delta^{13} \mathrm{C}$ determinations with EEM-PARAFAC data was used to confirm DOM sources and environmental drivers controlling spatial and temporal variations affecting the quantitative estimates of the contribution of DOM from seagrass communities in FB. The abovementioned approach confirmed previous suggestions that DOM dynamics in seagrass-dominated coastal bays can be driven by competing hydrology and primary productivity drivers. In addition, seasonal variations in these data suggest that dry season and early wet season DOM production from seagrasses may not exclusively be driven by primary productivity, but that senescence of seagrass and the resulting detritus may also make an important contribution to the DOM pool. Spatial and seasonal variations in seagrass-derived DOM may also be influenced by nutrient availability (and associated primary productivity). Seagrass communities were determined to be the main source of DOM in the bay, with estimates ranging from $c a$. $72 \%$ to $33 \%$ between the dry and wet season and regionally. While this study makes an important contribution in the efforts to constrain carbon budgets in subtropical estuaries 
of South Florida, seagrass habitats (incl. FB) have been reported as critical ecosystems in global blue carbon sequestration (Fourqurean et al., 2012).

However, these highly productive benthic communities are also suggested to significantly contribute to the DOM budget in such coastal environments. As such, FB serves as a representative example for seagrass-dominated estuaries and coastal bays, where the contribution of seagrass-derived DOC should be an important consideration for regional $\mathrm{C}$ cycling models. Constraining such models is critical in the sustainable management of the ecosystem services of sensitive marine environments. 


\section{REFERENCES}

Andersen, C.M., Bro, R., 2003. Practical aspects of PARAFAC modeling of fluorescence excitation-emission data. Journal of Chemometrics 17, 200-215.

Anderson, W.T., Fourqurean, J.W., 2003. Intra-and interannual variability in seagrass carbon and nitrogen stable isotopes from south Florida, a preliminary study. Organic Geochemistry 34, 185-194.

Apostolaki, E.T., Holmer, M., Marbà, N., Karakassis, I., 2010. Degrading seagrass (Posidonia oceanica) ecosystems: A source of dissolved matter in the Mediterranean. Hydrobiologia 649, 13-23.

Benner, R., Pakulski, J.D., McCarthy, M., Hedges, J.I., Hatcher, P.G., 1992. Bulk chemical characteristics of dissolved organic matter in the ocean. Science 255, 15611564.

Berryman, E., Marshall, J., Rahn, T., Cook, S., Litvak, M., 2011. Adaptation of continuous-flow cavity ring-down spectroscopy for batch analysis of $\delta^{13} \mathrm{C}$ of $\mathrm{CO} 2$ and comparison with isotope ratio mass spectrometry. Rapid Communications in Mass Spectrometry 25, 2355-2360.

Bianchi, T.S., 2007. Biogeochemistry of estuaries. Oxford University Press New York.

Bouillon, S., Dehairs, F., Schiettecatte, L.S., Borges, A.V., 2007. Biogeochemistry of the Tana estuary and delta (northern Kenya). Limnology and Oceanography 52, 46-59.

Boyer, J.N., Fourqurean, J.W., Jones, R.D., 1997. Spatial characterization of water quality in Florida Bay and Whitewater Bay by multivariate analyses: zones of similar influence. Estuaries 20, 743-758.

Bro, R., 1997. PARAFAC. Tutorial and applications. Chemometrics and Intelligent Laboratory Systems 38, 149-171.

Cawley K.M, Ding Y., Fourqurean J., Jaffé R., 2012. Characterizing the sources and fate of dissolved organic matter in Shark Bay, Australia: A preliminary study using optical properties and stable carbon isotopes. Marine and Freshwater Research 63, 1098-1107.

Cawley, K. M., Yamashita, Y., Maie, N., Jaffé, R., 2014. Using optical properties to quantify fringe mangrove inputs to the dissolved organic matter (DOM) pool in a subtropical estuary. Estuaries and Coasts 37, 399-410. 
Chen, M., Maie, N., Parish, K., Jaffé, R., 2013. Spatial and temporal variability of dissolved organic matter quantity and composition in an oligotrophic subtropical coastal wetland. Biogeochemistry 115, 1-17.

Chen, M., Jaffé, R., 2014. Photo-and bio-reactivity patterns of dissolved organic matter from biomass and soil leachates and surface waters in a subtropical wetland. Water Research 61, 181-190.

Chin, Y.P., Aiken, G., O'Loughlin, E., 1994. Molecular weight, polydispersity, and spectroscopic properties of aquatic humic substances. Environmental Science and Technology 28, 1853-1858.

Coble, P.G., 1996. Characterization of marine and terrestrial DOM in seawater using excitation-emission matrix spectroscopy. Marine Chemistry 51, 325-346.

Cory, R.M., McKnight, D.M., 2005. Fluorescence spectroscopy reveals ubiquitous presence of oxidized and reduced quinones in dissolved organic matter. Environmental Science and Technology 39, 8142-8149.

Fellman, J.B., Hood, E., Spencer, R.G., 2010. Fluorescence spectroscopy opens new windows into dissolved organic matter dynamics in freshwater ecosystems: A review. Limnology and Oceanography 55, 2452-2462.

Fleming, M., Lin, G., Sternberg, L.d.S.L., 1990. Influence of mangrove detritus in an estuarine ecosystem. Bulletin of Marine Science 47, 663-669.

Fourqurean, J., Willsie, A., Rose, C., Rutten, L., 2001. Spatial and temporal pattern in seagrass community composition and productivity in south Florida. Marine Biology 138, 341-354.

Fourqurean, J.W., Duarte, C.M., Kennedy, H., Marbà, N., Holmer, M., Mateo, M.A., Apostolaki, E.T., Kendrick, G.A., Krause-Jensen, D., McGlathery, K.J., 2012. Seagrass ecosystems as a globally significant carbon stock. Nature Geoscience 5, 505-509.

Fourqurean, J.W., Powell, G.V., Kenworthy, W.J., Zieman, J.C., 1995. The effects of long-term manipulation of nutrient supply on competition between the seagrasses Thalassia testudinum and Halodule wrightii in Florida Bay. Oikos 72, 349-358.

Fourqurean, J. W., Escorcia, S. P., Anderson, W. T., Zieman, J. C., 2005. Spatial and seasonal variability in elemental content, $\delta^{13} \mathrm{C}$, and $\delta^{15} \mathrm{~N}$ of Thalassia testudinum from South Florida and its implications for ecosystem studies. Estuaries 28, 447-461.

Fourqurean, J.W., Zieman, J.C., Powell, G.V., 1992. Phosphorus limitation of primary production in Florida Bay: Evidence from $\mathrm{C}$ : N: P ratios of the dominant seagrass Thalassia testudinum. Limnology and Oceanography 37, 162-171. 
Hedges, J. I., Keil, R. G., Benner, R., 1997. What happens to terrestrial organic matter in the ocean? Organic Geochemistry 27, 195-212.

Hansell, D.A., Carlson, C.A., 2002. Biogeochemistry of Marine Dissolved Organic Matter.Elsevier Science (USA). Preface, 21-22.

Hartland, A., Baker, A., Timms, W., Shutova, Y., Yu, D., 2012. Measuring dissolved organic carbon $\delta^{13} \mathrm{C}$ in freshwaters using total organic carbon cavity ring-down spectroscopy (TOC-CRDS). Environmental Chemistry Letters 10, 309-315.

Hemminga, M., Mateo, M., 1996. Stable carbon isotopes in seagrasses: variability in ratios and use in ecological studies. Marine Ecology Progress Series 140, 285-298.

Hendriks, I.E., Sintes, T., Bouma, T.J., Duarte, C.M., 2008. Experimental assessment and modeling evaluation of the effects of seagrass Posidonia oceanica on flow and particle trapping. Marine Ecology Progress Series 356, 163-173.

Holmer, M., Andersen, F., Holmboe, N., Kristensen, E., Thongtham, N., 2001. Spatial and temporal variability in benthic processes along a mangrove-seagrass transect near the Bangrong Mangrove, Thailand. Wetlands Ecology and Management 9, 141-158.

Hopkinson, C.S., Vallino, J.J., 2005. Efficient export of carbon to the deep ocean through dissolved organic matter. Nature 433, 142-145.

Houghton, R., 2007. Balancing the global carbon budget. Annual Review Earth Planet Science $35,313-347$.

Jaffé, R., Boyer, J., Lu, X., Maie, N., Yang, C., Scully, N., Mock, S., 2004. Source characterization of dissolved organic matter in a subtropical mangrove-dominated estuary by fluorescence analysis. Marine Chemistry 84, 195-210.

Kennedy, H., Beggins, J., Duarte, C.M., Fourqurean, J.W., Holmer, M., Marbà, N., Middelburg, J.J., 2010. Seagrass sediments as a global carbon sink: Isotopic constraints. Global Biogeochemical Cycles 24, 1-8.

Kieckbusch, D.K., Koch, M.S., Serafy, J.E., Anderson, W., 2004. Trophic linkages among primary producers and consumers in fringing mangroves of subtropical lagoons. Bulletin of Marine Science 74, 271-285.

Kirkman, H., Reid, D., 1979. A study of the role of the seagrass Posidonia australis in the carbon budget of an estuary. Aquatic Botany 7, 173-183.

Lambert, T., Pierson-Wickmann, A. C., Gruau, G., Jaffrezic, A., Petitjean, P., Thibault, J. N., Jeanneau, L., 2013. New insights from the use of carbon isotopes as tracers of DOC 
sources and DOC transport processes in headwater catchments. Biogeosciences Discussions 10, 17965-18007.

Loneragan, N., Bunn, S., Kellaway, D., 1997. Are mangroves and seagrasses sources of organic carbon for penaeid prawns in a tropical Australian estuary? A multiple stableisotope study. Marine Biology 130, 289-300.

Lu, X., Maie, N., Hanna, J., Childers, D., Jaffé, R., 2003. Molecular characterization of dissolved organic matter in freshwater wetlands of the Florida Everglades. Water Research 37, 2599-2606.

Lalonde, K., Vähätalo, A. V., Gélinas, Y.,2014. Revisiting the disappearance of terrestrial dissolved organic matter in the ocean: a $\delta^{13} \mathrm{C}$ study. Biogeosciences 11, 3707-3719.

Maher, D. T., Eyre, B. D.,2010.Benthic fluxes of dissolved organic carbon in three temperate Australian estuaries: Implications for global estimates of benthic DOC fluxes. Journal of Geophysical Research: Biogeosciences 115, G04039.

Maie, N., Boyer, J.N., Yang, C., Jaffé, R., 2006a. Spatial, geomorphological, and seasonal variability of CDOM in estuaries of the Florida Coastal Everglades.

Hydrobiologia 569, 135-150.

Maie,N., Jaffé, R.,Miyoshi,T.,Childers,D.L.,2006b.Quantitative and qualitative aspects of dissolved organic carbon leached from plants in an oligotrophic wetland. Biogechemistry $78,285-314$.

Maie, N., Yamashita, Y., Cory, R., Boyer, J.N., Jaffé, R., 2012. Application of excitation emission matrix fluorescence monitoring in the assessment of spatial and seasonal drivers of dissolved organic matter composition: sources and physical disturbance controls. Applied Geochemistry 27, 917-929.

Maie, N., Yang, C., Miyoshi, T., Parish, K., Jaffé, R., 2005. Chemical characteristics of dissolved organic matter in an oligotrophic subtropical wetland/estuarine ecosystem. Limnology and Oceanography 50, 23-35.

Marguillier, S., Van der Velde, G., Dehairs, F., Hemminga, M., Rajagopal, S., 1997. Trophic relationships in an interlinked mangrove-seagrass ecosystem as traced by $\delta^{13} \mathrm{C}$ and $\delta^{15}$ N. Marine Ecology Progress Series 151, 115-121.

McKnight, D.M., Boyer, E.W., Westerhoff, P.K., Doran, P.T., Kulbe, T., Andersen, D.T., 2001. Spectrofluorometric characterization of dissolved organic matter for indication of precursor organic material and aromaticity. Limnology and Oceanography 46, 38-48. 
Moncreiff, C.A., Sullivan, M.J., 2001. Trophic importance of epiphytic algae in subtropical seagrass beds: evidence from multiple stable isotope analyses. Marine Ecology Progress Series 215, 93-106.

Moncreiff, C.A., Sullivan, M.J., Daehnick, A.E., 1992. Primary production dynamics in seagrass beds of Mississippi Sound: the contributions of seagrass, epiphytic algae, sand microflora, and phytoplankton. Marine Ecology Progress Series 87, 161-161.

Munksgaard, N.C., Wurster, C.M., Bird, M.I., 2011. Continuous analysis of $\delta^{18} \mathrm{O}$ and $\delta \mathrm{D}$ values of water by diffusion sampling cavity ring-down spectrometry: a novel sampling device for unattended field monitoring of precipitation, ground and surface waters. Rapid Communications in Mass Spectrometry 25, 3706-3712.

Osburn, C.L., Stedmon, C.A., 2011. Linking the chemical and optical properties of dissolved organic matter in the Baltic-North Sea transition zone to differentiate three allochthonous inputs. Marine Chemistry 126, 281-294.

Phillips, D.L., Gregg, J.W., 2003. Source partitioning using stable isotopes: coping with too many sources. Oecologia 136, 261-269.

Prahl, F., Ertel, J., Goni, M., Sparrow, M., Eversmeyer, B., 1994. Terrestrial organic carbon contributions to sediments on the Washington margin. Geochimica et Cosmochimica Acta 58, 3035-3048.

Rivera-Monroy, V.H., Twilley, R.R., Davis III, S.E., Childers, D.L., Simard, M., Chambers, R., Jaffé, R., Boyer, J.N., Rudnick, D.T., Zhang, K., 2011. The role of the Everglades Mangrove Ecotone Region (EMER) in regulating nutrient cycling and wetland productivity in south Florida. Critical Reviews in Environmental Science and Technology 41, 633-669.

Robblee, M., Barber, T., Carlson Jr, P., Durako, M., Fourqurean, J., Muehlstein, L., Porter, D., Yarbro, L., Zieman, R., Zieman, J., 1991. Mass mortality of the tropical seagrass Thalassia testudinum in Florida Bay(USA). Marine ecology progress series. Marine Ecology Progress Series 71, 297-299.

Rochelle-Newall, E., Fisher, T., 2002. Production of chromophoric dissolved organic matter fluorescence in marine and estuarine environments: an investigation into the role of phytoplankton. Marine Chemistry 77, 7-21.

Romera-Castillo, C., Sarmento, H., Alvarez-Salgado, X.A., Gasol, J.M., Marrasé, C., 2010. Production of chromophoric dissolved organic matter by marine phytoplankton. Limnology and Oceanography 55, 446-454. 
Stutter, M. I., Langan, S. J.,Cooper, R. J., 2008. Spatial and temporal dynamics of stream water particulate and dissolved $\mathrm{N}, \mathrm{P}$ and $\mathrm{C}$ forms along a catchment transect, NE Scotland. Journal of Hydrology 350, 187-202.

Singh, S., D'Sa, E.J., Swenson, E.M., 2010. Chromophoric dissolved organic matter (CDOM) variability in Barataria Basin using excitation-emission matrix (EEM) fluorescence and parallel factor analysis (PARAFAC). Science of the Total Environment 408, 3211-3222.

Spencer, R. G., Stubbins, A., Hernes, P. J., Baker, A., Mopper, K., Aufdenkampe, A. K., Dyda,R.Y., Mwamba,V.L., Mangangu,A.M., Wabakanghanzi,J.N.,Six, J., 2009.

Photochemical degradation of dissolved organic matter and dissolved lignin phenols from the Congo River. Journal of Geophysical Research: Biogeosciences 114, G03010. Stabenau, E.R., Zepp, R.G., Bartels, E., Zika, R.G., 2004. Role of the seagrass Thalassia testudinum as a source of chromophoric dissolvedorganic matter in coastal south Florida. Marine Ecology Progress Series 282, 59-72.

Stedmon, C.A., Bro, R., 2008. Characterizing dissolved organic matter fluorescence with parallel factor analysis: a tutorial. Limnology and Oceanography. Methods 6, 572-579.

Stedmon, C.A., Markager, S., Bro, R., 2003. Tracing dissolved organic matter in aquatic environments using a new approach to fluorescence spectroscopy. Marine Chemistry 82, 239-254.

Stern, J., Wang, Y., Gu, B., Newman, J., 2007. Distribution and turnover of carbon in natural and constructed wetlands in the Florida Everglades. Applied Geochemistry 22, 1936-1948.

Scully, N. M., Maie, N., Dailey, S. K., Boyer, J. N., Jones, R. D., Jaffé, R., 2004. Early diagenesis of plant-derived dissolved organic matter along a wetland, mangrove, estuary ecotone. Limnology and Oceanography 49, 1667-1678.

Wang, Y., Hsieh, Y., Landing, W., Choi, Y., Salters, V., Campbell, D., 2002. Chemical and carbon isotopic evidence for the source and fate of dissolved organic matter in the northern Everglades. Biogeochemistry 61, 269-289.

Williams, C.J., Jaffé, R., Anderson, W.T., Jochem, F.J., 2009. Importance of seagrass as a carbon source for heterotrophic bacteria in a subtropical estuary (Florida Bay).

Estuarine, Coastal and Shelf Science 85, 507-514.

Wu, F., Tanue, E., 2001. Sensitive determination of dissolved tryptophan in freshwater by alkaline hydrolysis and HPLC. Analytical sciences 17, 1063-1066. 
Xu, Y., Holmes, C.W., Jaffé, R., 2007. Paleoenvironmental assessment of recent environmental changes in Florida Bay, USA: A biomarker based study. Estuarine, Coastal and Shelf Science 73, 201-210.

Xu, Y.,Jaffé, R. 2007. Lipid biomarkers in suspended particles from a subtropical estuary: assessment of seasonal changes in sources and transport of organic matter. Marine Environmental Research 64, 666-678.

Yamashita, Y., Scinto, L.J., Maie, N., Jaffé, R., 2010. Dissolved organic matter characteristics across a subtropical wetland's landscape: application of optical properties in the assessment of environmental dynamics. Ecosystems 13, 1006-1019.

Yamashita Y., Boyer J.N., Jaffé R., 2013. Evaluating the distribution of terrestrial dissolved organic matter in a complex coastal ecosystem using fluorescence spectroscopy. Continental Shelf Research 66,136-144.

Ziegler, S., Benner, R., 1999. Dissolved organic carbon cycling in a subtropical seagrassdominated lagoon. Marine Ecology Progress Series 180, 149-160.

Ziegler, S., Benner, R., 2000. Effects of solar radiation on dissolved organic matter cycling in a subtropical seagrass meadow. Limnology and Oceanography 45, 257-266.

Zieman, J., Macko, S., Mills, A., 1984. Role of seagrasses and mangroves in estuarine food webs: temporal and spatial changes in stable isotope composition and amino acid content during decomposition. Bulletin of Marine Science 35, 380-392.

Zieman, J.C., Fourqurean, J.W., Frankovich, T.A., 1999. Seagrass die-off in Florida Bay: Long-term trends in abundance and growth of turtle grass, Thalassia testudinum.

Estuaries 22, 460-470. 
CHAPTER III

CHARACTERIZING SOURCES AND FATE OF DISSOLVED ORGANIC MATTER IN THE ALTAMAHA RIVER ESTUARY 


\subsection{Abstract}

Spatial and temporal variations of dissolved organic matter (DOM) concentration (DOC) and composition were characterized along the salinity gradient of the Altamaha River estuary, Georgia, USA, to better understand carbon dynamics in this riverinfluenced, coastal marsh ecosystem. Fluorescence excitation emission matrix coupled with parallel factor analysis (EEM-PARAFAC) was used to analyze DOM composition. EEM-PARAFAC modeling resulted in a four-component model with two humic-like components, one protein-like component and one microbial humic-like component. During the dry season, both DOC concentration and PARAFAC components abundance showed a non-conservative mixing pattern along the Altamaha River estuary, indicative of DOM inputs potentially from the tidal marsh system in the mid-estuary. However, the relative contribution of DOM from salt marshes is highly variable between seasons and sampling events and likely driven by hydrologic conditions. During the wet season, the estuary was freshwater end-member dominated and salt marsh-derived DOM was diluted by the high volume of freshwater input resulting in a conservative mixing patter along the salinity gradient. In addition, both quality and quantity of DOM changed markedly after storm events due to the runoff contribution from the riparian zone. Through isotopic analysis, depletion in $\delta^{13} \mathrm{C}$ values was observed in the mid-estuary region (-28\%o - $27 \%$ o) possibly due to the input of DOM from brackish tidal marshes dominated by Juncus ( $27 \%$ ), followed by a seaward enrichment in $\delta^{13} \mathrm{C}$ likely from the pelagic organic matter sources. Plant and soil leaching experiments showed prevalence in protein-like fluorescence in plant leachates and an enriched fulvic acid-like fluorescence in the soil leachates. Therefore, while the increased protein-like content observed during the wet 
season is likely attributed to the leaching of freshwater/salt marsh plants, the increased fulvic acid-like abundance observed during the storm season is likely originated from storm-induced soil erosion. Nevertheless, the general composition of surface water DOM was significantly different from the plant leachates due to microbial reworking, resulting in more humic-like enriched, potentially more refractory DOM in surface water. Overall, the Altamaha estuary is a freshwater dominated ecosystem with higher richness of biomass at freshwater sites that serve as the primary source of DOM while salt marsh vegetation affect the distribution pattern of DOM quality and quantity.

\subsection{Introduction}

Dissolved organic matter (DOM) plays an important role in the global carbon cycle. For the last decades, DOM dynamics and function in aquatic ecosystem have been an important aspect of ecological research (Aitkenhead-Peterson et al., 2003; Wetzel 1984; Thomas 1997; Stedmon et al., 2003; Battin et al., 2009). Among these, DOM in estuaries has been widely studied because of its importance in a variety of physical, geochemical, and biological processes (Dankers et al., 1984; Peterson and Howarth, 1987; Jaffé et al., 2004; Weston et al., 2011). Estuaries are an important interface between land and ocean where terrigenous DOM is modified by microbial degradation (Stedmon and Markager, 2005), source change (Cawley et al., 2014) and physical/chemical removal from the water column (Eckert and Sholkovitz, 1976). Inputs of DOM to estuaries can come from the coastal ocean, riverine end-member and adjacent salt marshes (Bianchi, 2007). Riverine DOM is primarily derived from terrestrial plant/soils (Malcolm, 1990; Opsahl and Benner, 1997). It is generally considered to be 
enriched in humic-like, potentially more refractory substances, which are the major sources of reduced carbon to coastal environments (Moore et al., 1979; Mantoura and Woodward, 1983). Compared with labile algal components, terrestrial DOM is less likely to be consumed by microbial activity and thus often showed a conservative mixing throughout the estuary (Stedman and Markager 2003; Yamashita et al., 2011). The other major source of estuarine DOM is autochthonous production from planktonic primary production and/or from vascular plants of adjacent salt marshes. Salt marshes are considered to be highly productive environments within estuarine settings (Kirby and Gosselink, 1976; Pomeroy and Wiegert, 1981), exporting biologically available organic matter into near-shore waters (Odum, 1988; Tzortziou et al., 2008). Salt marsh-derived colored DOM (CDOM) has been reported as the main source at ebbing tide but found not to dominate the bulk pool at flooding tide (Tzortziou et al., 2008), and leaching of salt marsh plants could be the main sources of DOM in estuaries (Peterson et al., 1994). However, from a quantitative perspective, the significance of leachate export relative to in situ DOM production may vary in different ecosystems (Turner, 1993) and thus the accumulation, dynamics and fate of salt marsh exported DOM remains difficult to constrain.

The coastline of the state of Georgia, USA features a variety of estuarine ecosystems where the connection between rivers and coastal ocean is fringed with extensive salt marshes (Nixon, 1980). The Savannah, Altamaha, Ogeechee, Satilla and St. Johns rivers are the five major sources of freshwater discharge in the coastlines of Georgia and South Carolina (Dame et al., 2000). Among these, the Altamaha Estuary is a freshwater-dominated system as a result of high rate of freshwater inflow. It is an 
important drainage basin on the Georgia coast with remarkable hydrological change on a seasonal basis (Sheldon and Burd, 2014). Previous GIS classification on Georgia estuarine vegetation patterns suggested that Juncus roemeianus is the dominant species in both the Altamaha and Satilla estuaries followed by Spartina alterniflora (Higinbotham et al., 2004). The Spartina salt marshes respire over $70 \%$ of their primary produced carbon (Teal, 1962), but despite this high respiration rate, these salt marshes are known to export OM into the estuary (Teal, 1962), and salt marshes in Georgia estuaries have been reported to export DOM rich in lignin, and humic substances derived from vascular marsh plants (Moran and Hodson, 1989). Salt marsh exported OM inputs to coastal rivers are highly variable and controlled by river discharge (Dai and Sun, 2007). Shi et al. (2001) reported that C3 terrestrial plant OM was deposited in the Altamaha estuary during the high discharge season, while during low discharge periods, C4 marsh plant derived OM (likely from the Spartina) also contributed a significant fraction (Dai and Sun, 2007). The OM distribution varied with ecological communities as well. Plant productivity and richness decreased from fresh to saline sites at the Altamaha estuary (Więski et al., 2010). Therefore, OM input of these plant-derived materials differed along the salinity gradient. Odum (1988) argued that salinity stress will reduce plant diversity in salt marshes, while lower salinity in tidal freshwater system should increase decomposition rate, net primary production and ultimately organic matter accumulation (Craft, 2007). Using salinity as a geological proxy, soil samples from different marshes arrayed along upstream, intermediate, and downstream landscape locations (freshwater, brackish and saltwater marsh) were studied. It was noted that organic matter accretion in soil differed along the estuary in Georgia coastline (e.g., the Altamaha river 
estuary)(Craft, 2007). However, not many studies have focused on characterizing the dynamics of OM in the dissolved phase (DOM) on temporal scales in such estuaries (Moran et al., 1991; Dai and Sun 2007).

DOM from different sources in estuaries may feature distinct chemical and isotopic signatures. Generally, most terrestrial DOM is derived from C3 plants, and consequently is characterized by depleted $\delta^{13} \mathrm{C}(-31 \%$ to $-26 \%$ ) values (Peterson and Fry 1989). In contrast, organic matter from Spartina dominated salt marshes (C4) is more enriched in ${ }^{13} \mathrm{C}\left(-16 \%\right.$ to $-12 \%$ ) (Haines 1977; Stribling and Cornwell 1997). The $\delta{ }^{13} \mathrm{C}$ values of autochtonous, estuarine or marine planktonic sources usually show intermediate values (Peterson et al., 1994). According to France (1995), water inundation will have an impact on ${ }^{13} \mathrm{C}$ depletion, thus $\delta^{13} \mathrm{C}$ for coastal phytoplankton was -22\%o compared to $17 \%$ for marine benthic algae. Multiple geochemical proxies have been applied to study the organic matter dynamics (both particulate and dissolved organic matter) in Georgia salt marsh estuaries. On the basis of the distinct isotopic signatures between $\mathrm{C} 3$ and $\mathrm{C} 4$ plants, stable carbon isotopes were used to trace organic matter flow from the salt marsh to the estuary (Peterson and Howarth 1987). Detrital OM derived from salt marshes plants (e.g., Spartina) were shown to be a much more important energy source for macroconsumers than terrestrial inputs and thus was largely consumed before reaching the surface water POM pool (Peterson et al.,1986). That explained why seston OM in tidal creeks and rivers at Sapelo Island, Georgia did not show similar $\delta^{13} \mathrm{C}$ values to those of Spartina due to the biological consumption (Haines, 1977). As for DOM specifically, lignin oxidation products were used to trace terrestrial/marsh inputs to the coastal shelf of Georgia (Gardner and Menzel, 1974; Moran et al., 1991; Hodson, 1991), and estimate the 
salt-marsh contribution to humic substances in the DOM pool. According to Moran (1999), lignin phenols only accounted for $0.14-1.0 \%$ of the bulk DOC in the Altamaha River. However, the bulk features of the DOM pool in this salt marsh dominated estuary are not well studied. The bio-available DOM components produced from the salt marsh vegetation are actively consumed by native salt marsh bacteria (Bushaw-Newton et al., 2008; Wang et al., 2007) and thus do not accumulate efficiently in the water column. DOM produced from decomposition of marsh plants can be exported to the main river channel through tidal pumping, but can also become trapped in the marsh (Teal.1962). Based on the biogeochemical processes mentioned above, the Spartina marshes might be relatively unimportant organic matter source to the Altamaha river estuary (Haines and Montague, 1979; Sherr, 1982). Similar to other estuarine systems previously studied (Tzortziou et al., 2008), there seems to be little consensus on the magnitude and direction of marsh-derived OM fluxes for the Altamaha estuary, and a comprehensive study on the sources and fate of bulk DOM is needed for the Altamaha River estuarine ecosystem.

Fluorescence excitation-emission matrix (EEM) combined with parallel factor analysis (PARAFAC) has been successfully used in discriminating allochothonous and autochthonous sources of DOM in estuaries (Spencer et al., 2007; Yamashita et al., 2008; Jaffé et al., 2014), and is an important analytical tool to resolve complex DOM dataset in coastal regimes (Singh et al., 2010; Yamashita et al., 2013). Two primary fluorescing groups in DOM were identified as humic-like and protein-like substances. Humic-like components are terrestrially derived substances with a mixed of aromatic and aliphatic structures. Protein-like substances generally imply more "freshly" produced organic components associated with microbial activity (Balcarczyk et al., 2009). While EEM- 
PARAFAC has widely been applied to the source characterization of DOM in a great variety of environmental settings (Jaffé et al., 2014), one limitation of this technique is that it can provide biomass-specific source information semi-quantitatively at best. In an estuarine setting, featuring different higher plant sources, such as freshwater, brackish and salt marshes, complementary techniques such as DOC stable isotope analysis may provide an useful approach to differentiate DOM from distinct origins (see above). The

combination of the two techniques (e.g., Osburn and Stedmon 2011) can be used to trace DOM source, correlation with ecological factors and characterize temporal and spatial variations (see chapter 2).

This study has three specific goals: 1) to characterize DOM composition, dynamics and fate along the Altamaha River estuary; 2) to identify potential sources of DOM in the estuary; 3) to assess the ecological drivers that control DOM variations (e.g. hydrology/precipitation, biomass etc.) in an attempt to explain the differences in the DOM characteristics over time and space in the Altamaha river estuary.

\subsection{Methods and Material}

\section{Sampling:}

The Altamaha River is one of the largest drainage basins $\left(33,000 \mathrm{~km}^{2}\right)$ on the East Coast of the United States. Vegetation type, biomass and nutrient retention were distinctly distributed along the salinity gradient as salinity records showed three salinity zones in the Altamaha River : freshwater marsh (upstream; ca. 1 psu), brackish marsh (1 to $15 \mathrm{psu}$ ), and salt marsh (lower estuary; 15psu and higher)(Higinbotham et al., 2004). In this system, dominant marsh vegetation such as Juncus and Spartina range from 
salinity of 21 to 1 where Juncus was the dominate species in the brackish marsh (Higinbotham et al., 2004). The mapping of vegetation distribution is shown in Fig. 3.1a. Climate, precipitation and river discharge are usually aggregated into seasonal grouping and used to define wet-dry hydrologic cycles (Katz et al., 2003). Four sampling trips for two wet (March 2011 and March 2012) and two dry seasons (August 2010 and September 2012) along the salinity gradient of the Altamaha River, were included in this study. The overall seasonality of precipitation on the Georgia coast is different between the upper and lower parts of the watershed. There are usually two-peak precipitation periods annually, with a stronger summer peak at the lower watershed (Sheldon and Burd, 2014), where our DOM sampling sites were located. Great variability of precipitation is observed from May to September, which is connected to tropical storms (Sheldon and Burd, 2014). The last sampling event during this study (September 2012) was conducted right after such a peak of elevated coastal precipitation period and was characterized as 'storm' season. A total of 87 surface water samples were collected along the Altamaha salinity transect for the two wet (March) and dry seasons (August) using pre-cleaned, acid/base-washed, brown, high-density polyethylene bottles $(60 \mathrm{ml}$, Nalgene). Surface water was filtered through pre-combusted $0.7 \mu \mathrm{m} \mathrm{GF} / \mathrm{F}$ glass fiber filters in the laboratory immediately after collection. Two groundwater samples were collected at Sapelo Island, Georgia by University of Georgia staff, filtered and stored in the same way as surface water samples, shipped to FIU for optical measurements. Fresh plant materials were collected from Cypress Taxodiumv, Spartina alterniflora and Juncus roemerianus and kept in pre-cleaned zip lock bags (Lab Safety Supply). Four soil samples from the freshwater marsh, brackish marsh, tidal creek and lower estuary were 
collected and stored in pre-combusted glass jars (I-Chem). All samples were stored on ice immediately after sampling and transported to laboratory, stored in a refrigerator $\left(4^{\circ} \mathrm{C}\right)$ until further processing. Water quality data was measured on site using a YSI 600XL probe.

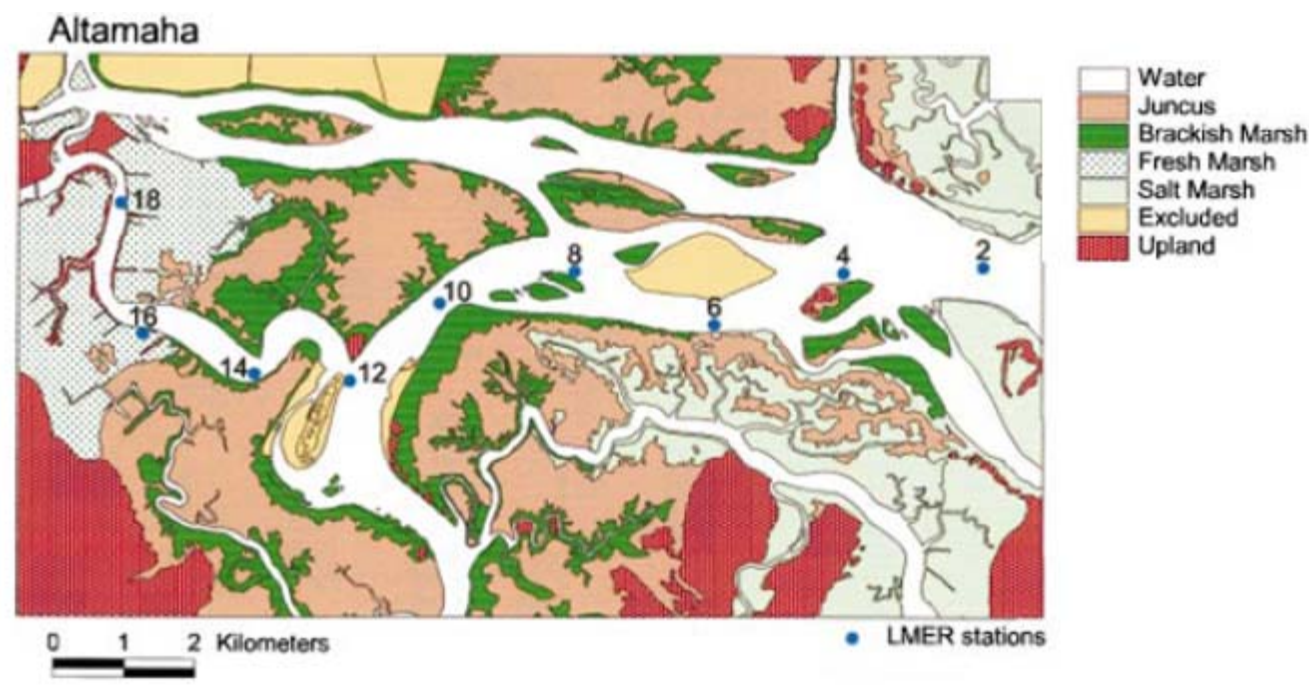

Figure 3.1a Vegetation classification of the Altamaha River estuary (Higinbotham et al., 2004).

\section{Analyses:}

Dissolved organic carbon (DOC) concentrations were measured using high temperature combustion on a Shimadzu TOC-5000 (Shimadzu Scientific Instruments, Columbia, MD, USA) equipped with a platinum catalyst and an infrared detector. The UV-visible absorbance was measured on a Varian spectrophotometer at a wavelength range of $200-800 \mathrm{~nm}$. The ratio slope of the $275-295 \mathrm{~nm}$ region and the $350-400 \mathrm{~nm}$ region was used to evaluate DOM molecular weight (Helms et al., 2008). Fluorescence excitation emission matrices (EEMs) were measured on a Horiba Jobin Yvon SPEX Fluoromax-3 spectrofluorometer (Horiba Scientific, Edison, NJ, USA). The EEMs were 
collected over an excitation range of 240-450 $\mathrm{nm}$ with an increment of $5 \mathrm{~nm}$ and an emission range of 300-550 nm with an increment of $2 \mathrm{~nm}$ in a $1 \mathrm{~cm}$ quartz cuvette. EEMs were corrected using Matlab 7.0.4. Instrument shifts were corrected using excitation and emission factor. Corrections also include inner-filter effect, Raman area normalization and blank subtraction. A parallel factor analysis (PARAFAC) model was built using 87 corrected EEMs with an N-way Matlab toolbox (Stedmon and Bro, 2008) and validated through split-half analysis. Optical property, fluorescence index (FI) was calculated as the ratio of the emission intensities at $470 \mathrm{~nm}$ and $520 \mathrm{~nm}$ at an excitation wavelength of $370 \mathrm{~nm}$.

Samples for stable isotope analysis were extracted through a solid phase extraction (SPE) using Variant Bond Elut PPL (1g) cartridges. This technique is one of the most efficient methods for DOM extraction (Dittmar et al., 2008). About $2 \mathrm{~L}$ filtered sample was acidified to $\mathrm{pH}=2$ using concentrated $\mathrm{HCl}$. The PPL cartridges were conditioned using methanol (20 ml, HPLC grade) before applying samples. Samples were fed onto the PPL cartridge under gravity. Salts were eliminated by rinsing with $0.01 \mathrm{~N}$ $\mathrm{HCl}$ immediately after adsorption. Cartridges were then dried under $\mathrm{N}_{2}$ gas stream and eluted with $20 \mathrm{~mL} \mathrm{MeOH}$. The eluates were stored in $\mathrm{MeOH}$ at $-18^{\circ} \mathrm{C}$. The extraction efficiency for DOC by this SPE technique was reported to be $61 \%$ (Dittmar, 2008; Green et al., 2014). The extract ( $\sim 100$ ug DOC) was pipetted into a tin capsule and dried at 40 ${ }^{\circ} \mathrm{C}$. Stable ${ }^{13} \mathrm{C}$ isotope analysis was performed at the FIU SERC Stable Isotope Laboratory using standard elemental analyzer isotope ratio mass spectrometer (EAIRMS) procedures (Anderson and Fourqurean, 2003). Samples were combusted in EA, forming $\mathrm{CO}_{2}$ and then measured on a Finnigan MAT Dalta C IRMS in a continuous flow 
mode. Isotope results were reported as isotope ratio in the standard delta notation (\%o): $(\%)=\left[\left(\mathrm{R}_{\text {sample }} / \mathrm{R}_{\text {standard }}-1\right] \times\right.$ 1000.International standard for carbon is Vienna PeeDee belemnite (V-PDB). Analytical reproducibility of this method based on internal standards is $\pm 0.05 \%$.

\section{Leaching experiments:}

Biomass and soil samples (about $15 \mathrm{~g} / \mathrm{L}$ wet weight for cypress, Spartina and Juncus, $50 \mathrm{~g} / \mathrm{L}$ for soil) were submerged into pre-combusted Erlenmeyer flasks containing $1 \mathrm{~L}$ of water. In the leaching experiment, salinity was mimicked according to the corresponding sampling site. For salt marsh plants (Spartina and Juncus), artificial sea salt (instant ocean aquarium, Petco Inc.) was added to the DI water to mimic the salinity in the corresponding sampling site (salinity 15). For freshwater plants (cypress), tap water was used to mimic the natural composition of water. Plant leaves were cut into small pieces ( $\sim 3$ inches) to facilitate leaching. Flasks were covered and wrapped with aluminum foil to avoid photo-degradation during the leaching process. The flasks were placed onto a shaker to enhance desorption and diffusion while they were static for the biomass and soils. Room temperature during the 1-day leaching experiments was about $20^{\circ} \mathrm{C}$. The leachates were filtered through $0.7 \mu \mathrm{m} \mathrm{GF} / \mathrm{F}$ filters and further diluted to the average UV-Vis absorbance of $\sim 0.2(254 \mathrm{~nm})$. Blank (tap water) was subtracted for DOC and spectroscopic measurements. For better comparison of their leaching capability, leached mass of DOM was normalized to the dry weight of the biomass and soils used.4 


\section{Statistical analyses:}

Statistical analysis, including principal component analysis (PCA), t-test and linear correlation were conducted using SPSS 17.0 (IBM, Armonk, NY, USA). Graphing, including stacked bar, scatter point was conducted using Sigmaplot. In order to assess marsh vs. upper watershed contributions, DOC and PARAFAC component values were plotted against salinity, and the areas under and above the upper and lower boundaries of the $95 \%$ confidence interval fit to the theoretical conservative mixing line were determined. The conservative mixing line was determined by fitting a line between freshwater end-member ( $n=12$ Aug-2010; $n=13$ Mar-2011; n=8 Mar-2012 and n- 4 Sep2012) and the marine end-member ( $n=1$ Aug-2010; $n=1$ Mar-11; $n=1$ Mar-12 and $n=2$ Sep-12). The marsh contributions were determined by the difference between the total area and the area underneath the conservative mixing line. Data points collected were interpolated to 0.1 salinity increments and integrated by a left sum method using Matlab 7.8.0. The percentage value was the difference between the area under the conservative mixing line and the area under the measured data divided by the area of the measured data and multiplied by 100 (presented in Table 3.1b). The difference between the best fit and the $95 \%$ confidence line are presented in parenthesis in Table 3.1b. A two-tailed F test $(90 \%$ confidence level) was used to determine whether measurements were statistically similar to the conservative mixing line. 


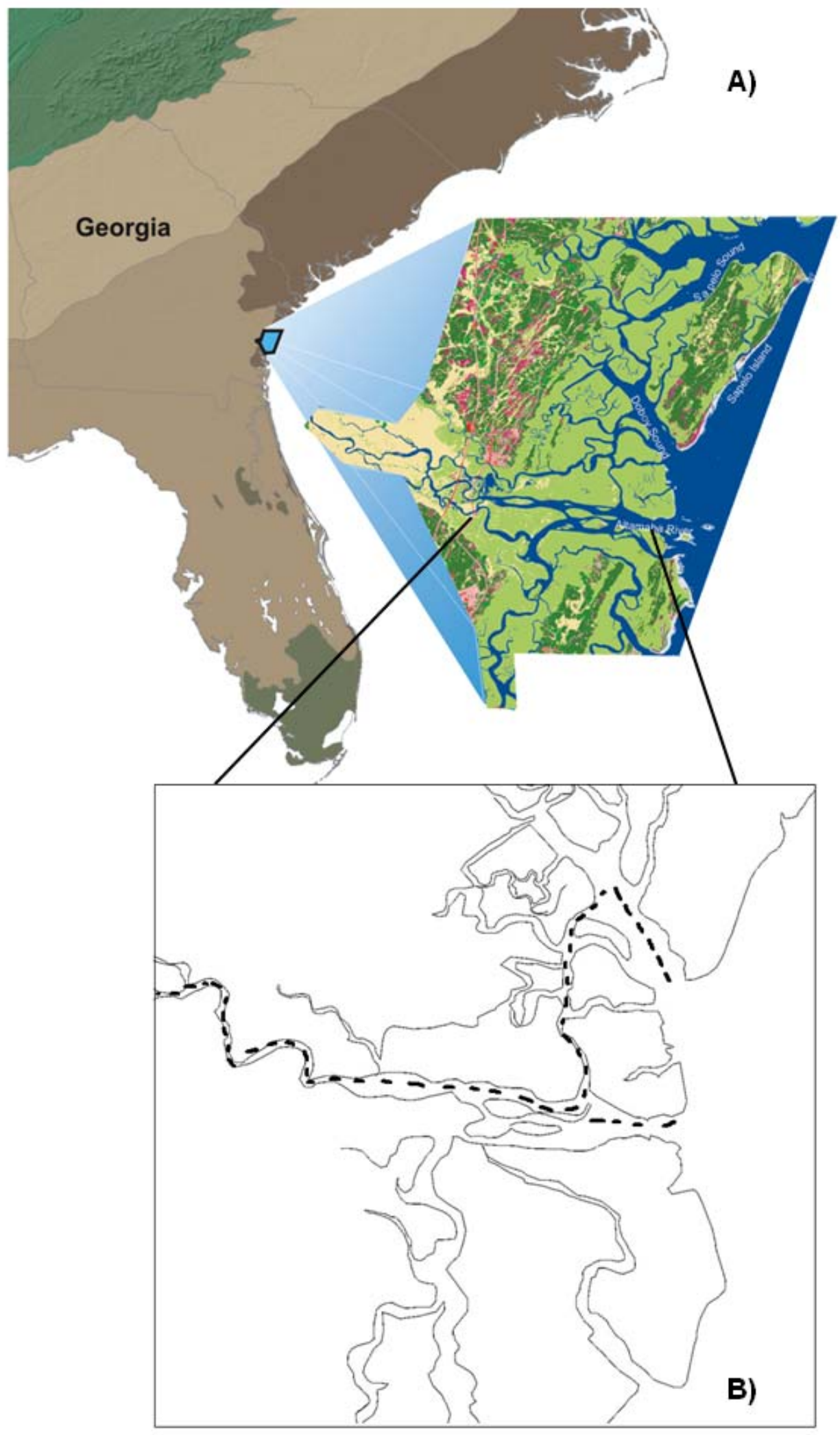




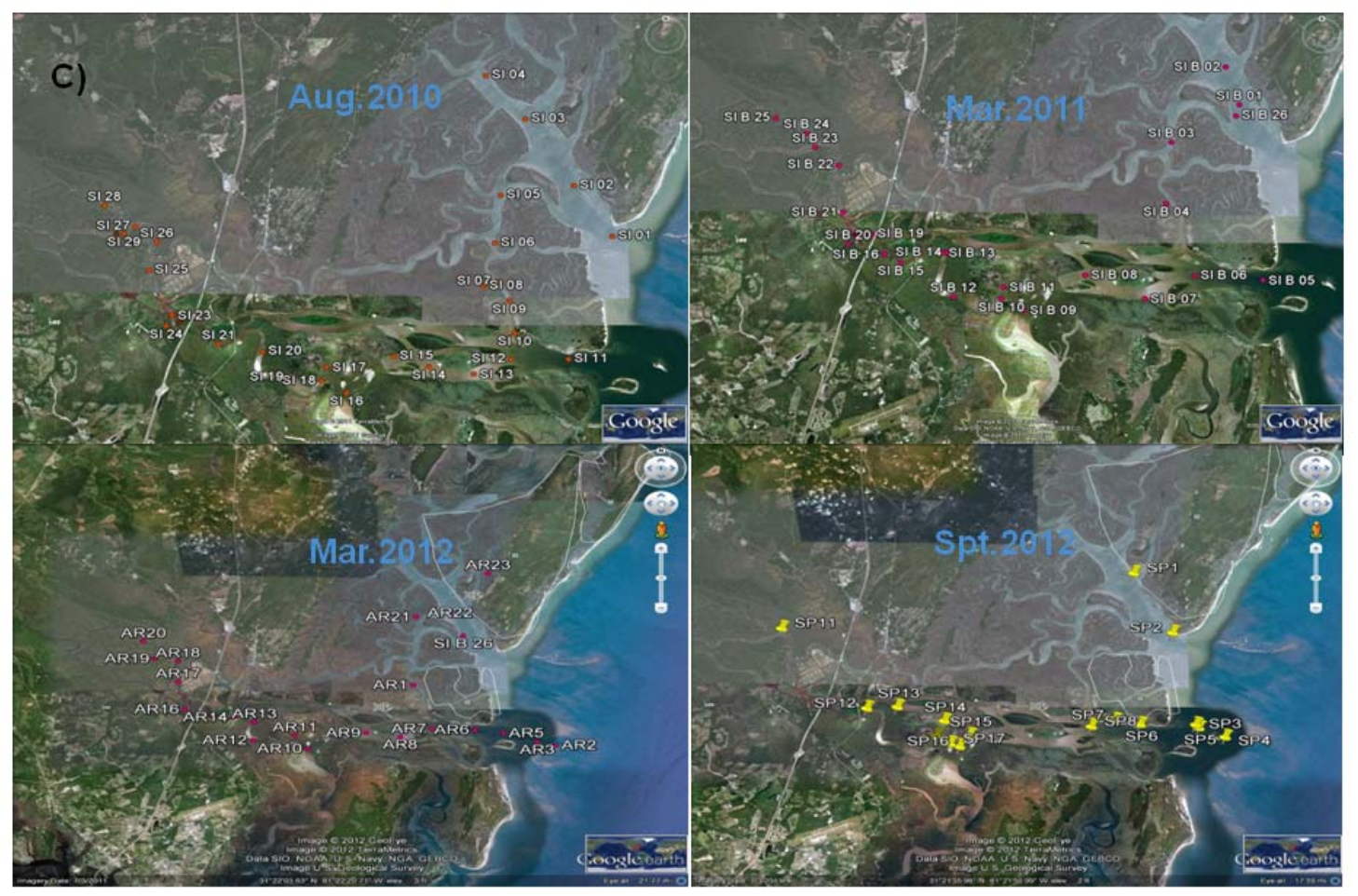

Figure 3.1b A) Map of Georgia coastal ecosystem-the study domain of Long Term Ecological Research (https://gce-lter.marsci.uga.edu/); B) Conceptual study transect along the Altamaha River estuary C) Four sampling transects in two wet seasons (Mar. 2011 and 2012), one dry season (Aug. 2010) and one storm season (Spt. 2012)

\subsection{Results and Discussion}

\subsubsection{DOC and optical properties}

Dissolved organic carbon concentrations varied on both temporal and spatial scales along the Altamaha River estuary (see Table 3.1a; Fig. 3.2). Seasonally, DOC ranged from 2.00 to $4.50 \mathrm{mg} / \mathrm{L}$ in March 2011 (wet season), 2.91 to $7.12 \mathrm{mg} / \mathrm{L}$ in August 2010 (dry season), 2.42 to $9.41 \mathrm{mg} / \mathrm{L}$ in March 2012 (wet season) and 0.70 to $21.10 \mathrm{mg} / \mathrm{L}$ in September 2012 (Storm season). Average DOC values during 2011 were significantly lower compared to $2012(\mathrm{p}<0.05)$ (Table 3.1). The storm season in 2012 (September) . 
showed the highest average DOC concentration compared with the dry season and two wet seasons (Table 3.1). Year 2012 showed precipitation 20\% higher than 2011 (Fig. 3.3). Consequently, there is a clear increase in DOC concentration during the high precipitation year (Fig. 3.3). The two sampling trips in 2012 were conducted after the peak precipitation (Fig. 3.3) and thus greater amounts of dissolved organic carbon are possibly introduced by runoff from the riparian zone during the course of rainfall events. Several studies have reported the importance of precipitation to DOC export (Brown et al., 1999; Hinton et al., 1998). Dissolved organic C export has been shown to respond sensitively to storm events, when an estimated $86 \%$ of DOC is exported (Raymond and Saiers, 2010). As the intensity of DOM fluorescence is often correlated with DOC concentration (Jaffé et al., 2004), the total fluorescence showed similar response to precipitation (Fig.3.3), with a significantly higher amount of fluorescent organic components exported during the storm season of 2012. The storm not only brings large volume of land run-off into the Altamaha River, but it might also change the DOM quality by supplying more terrestrial OM due to soil-water flushing (see further discussion on DOM optical properties below). 

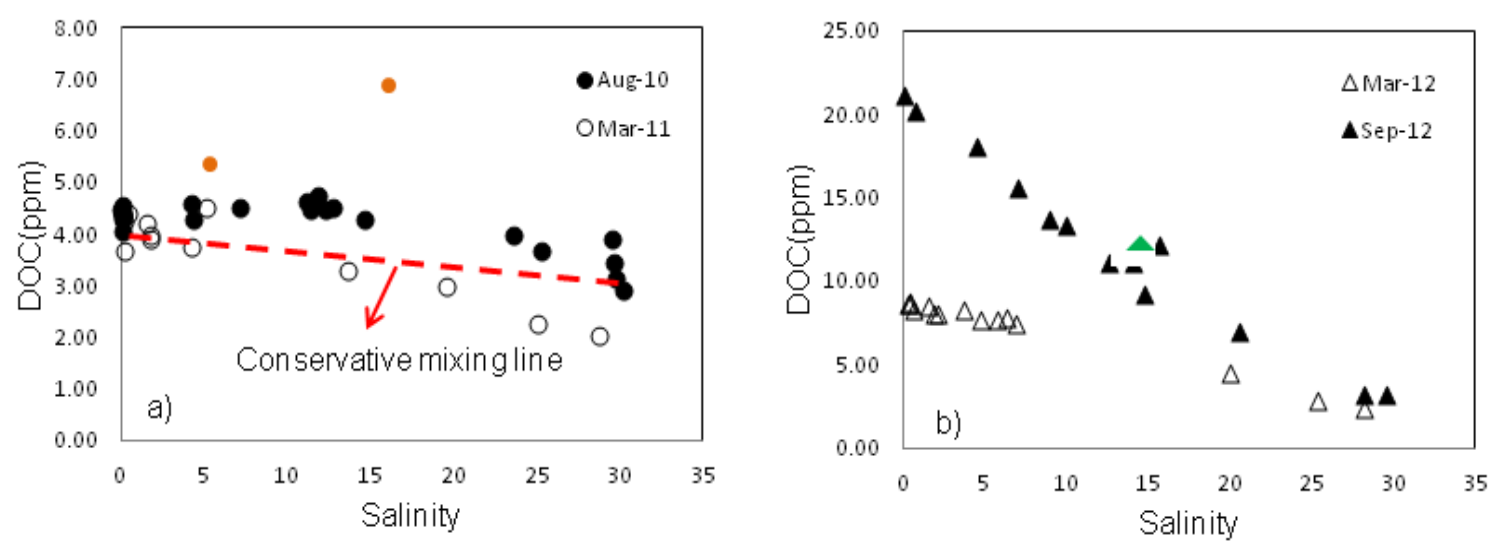

Figure 3.2 DOC concentration along the Altamaha salinity transects in wet season and dry season (black dots: dry season; white circles: wet season). Color coded data points indicate samples from salt marsh creeks (yellow= Aug-10; green= Sep-12)

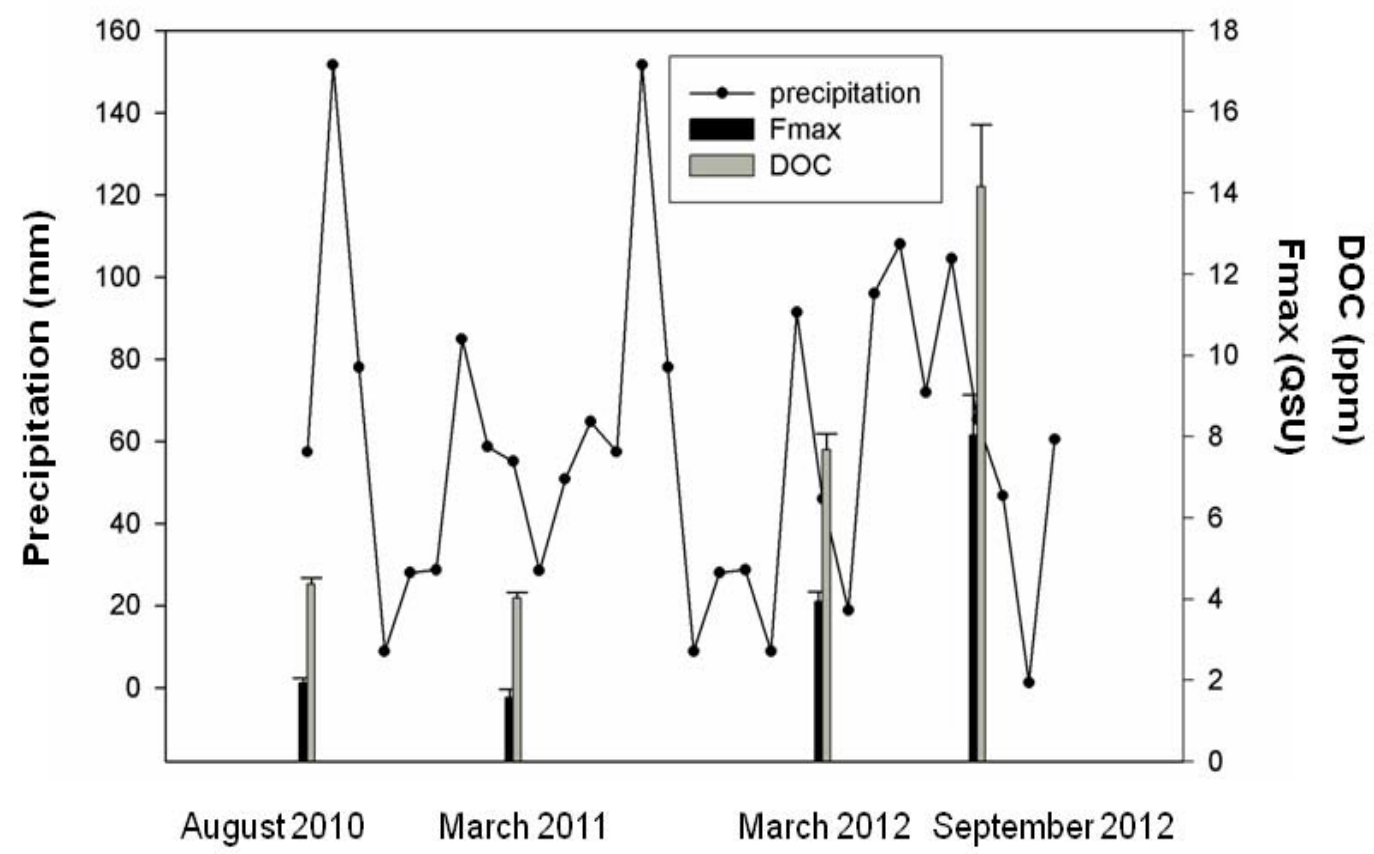

Figure 3.3 Variation of precipitation, total fluorescence (Fmax, QSU) and DOC concentration (ppm) during the four sampling event 
Table 3.1a DOC concentration and Optical properties of surface water/groundwater

\begin{tabular}{|c|c|c|c|c|c|c|c|}
\hline Sample date & $\mathbf{n}$ & Salinity range & River discharge $\left(\mathrm{ft}^{3} \mathrm{~s}^{-1}\right)$ & $\begin{array}{c}\text { Precipitation(total, } \\
\text { inch) }\end{array}$ & DOC (ppm) & FI & $\mathbf{S}_{\mathbf{R}}$ \\
\hline $8 / 4 / 2010$ & 24 & $0-30.2$ & 1850 & 0.25 & 4.36 & $1.31-1.42$ & $\begin{array}{l}0.91 \\
1.06\end{array}$ \\
\hline $3 / 14 / 2011$ & 23 & $0.1-28.7$ & 11800 & 0.96 & 4.00 & $1.27-1.38$ & $\begin{array}{l}0.83 \\
0.98\end{array}$ \\
\hline $3 / 14 / 2012$ & 23 & $0.3-28.2$ & 9040 & 3.62 & 7.69 & $1.30-1.39$ & $\begin{array}{l}0.69 \\
0.89\end{array}$ \\
\hline $9 / 8 / 2012$ & 17 & $0.1-29.6$ & 2460 & 2.80 & 13.31 & $1.23-1.38$ & $\begin{array}{l}0.61 \\
0.79\end{array}$ \\
\hline Dec.2012 & 1 & $\begin{array}{c}\text { Groundwater High } \\
\text { Tide }\end{array}$ & & & 8.01 & & 0.92 \\
\hline Dec. 2012 & 1 & $\begin{array}{c}\text { Groundwater Low } \\
\text { Tide }\end{array}$ & & & 7.94 & & 0.88 \\
\hline
\end{tabular}

Note**: cumulative precipitation is calculated for a two-week period before the sampling date; river discharge is calculated during the sampling period 
To assess the spatial variation of DOM, DOC concentration along the Altamaha River salinity transects is compared between dry and wet seasons. DOC vs. salinity distributions are shown in Figs. $3.2 \mathrm{a}$ and $\mathrm{b}$ and presented in Table 3.1a. Different mixing patters were observed for different seasons. Dry season (2010) showed a nonconservative mixing behavior along salinity transect (Fig. 3.2a), suggesting that DOC in the dry season is not only controlled by dilution but also by receiving external inputs from the mid-salinity estuarine zone where Spartina/Juncus marshes are abundant. Many studies have reported on the non-conservative mixing of DOC in estuaries as a result of external input from adjacent salt marshes or mangrove swamps (Peterson et al. 1994, Jaffé et al. 2004; Cawley et al., 2014). Based on this approach, in the Altamaha River estuary about $21 \%$ of DOC was contributed from the salt marsh environment in the salinity range of 5-25 during low river discharge (Dry season 2010), in agreement with a significant non-conservative mixing behavior along the salinity gradient (Table $3.2 b$ ). Similar observations were reported for another Spartina marsh estuarine system (Neponset River estuary, Boston Harbor, MA) where marsh-derived DOC export in the mid-salinity estuary generally peaked during late summer and contribute $10-50 \%$ of the CDOM to the system (Gardner et al., 2005). Consistently higher DOC loadings from the salt marsh creeks (Fig.3.2 colored data points) were also observed during both dry and wet seasons, suggesting active tidal pumping in this system. Although Spartina alterniflora and Juncus roemeianus biomass represent $70 \%-100 \%$ land cover in the Altamaha estuary (Higinbotham et al., 2004), biomass productivity on the Georgia coast has been reported as highest for freshwater marshes compared with salt marshes, and thus 
are likely the primary sources of DOM during wet season (Więski et al., 2010). There is a decline in the biomass along the salinity gradient of the Altamaha estuary (Fig. 3.4). Richness and diversity of biomass in salt marshes is significantly lower than freshwater marsh possibly due to the salinity stress (Odum, 1988), which ultimately reduced the organic matter accumulation in the salt marsh sites (Craft, 2007). These overall trends agree with our results showing a general decline of DOC from freshwater marsh towards the lower estuary in correspondence to the trend of plant biomass (Fig. 3.2 and Fig.3.4). The elevated biomass productivity at the freshwater marsh end-member likely results in a high DOC source which is diluted through conservative mixing when freshwater flow is high (wet season), with some minor contributions from the less productive brackish and salt marshes during the dry season (e.g., 2011 and 2012). Year 2012 showed significantly higher weight of biomass in freshwater marshes (Fig.3.4 site GCE7) compared with 2011, which might contribute to the high DOC concentration observed in freshwaterbrackish marshes during 2012 (Fig 3.2b and Table 3.1a). Therefore, salt marshes seem to be less significant contributors compared with freshwater marshes in the DOM pool of the Altamaha estuary. Despite of the relatively lower productivity of salt marshes, significant marsh-derived DOM was still observed during dry season (August 2010) in our study. Previous reports on the DOM and POM flux also showed evidence of measurable export from marsh tidal creeks in the Duplin River estuary, Georgia (Chalmers et al., 1985). However, DOM concentration has been noted to sensitively respond to river flow fluctuation and rainfall wash-out (Vogel et al., 2003; Wheatcroft et al., 2010). Both, an increase in river flow (see wet season data) as well as increments in local rainfall (September 2012), would result in the dilution of salt-marsh derived DOM 
by greater terrestrial inputs. Terrestrial input during the wet seasons (2011 and 2012) and during the storm season (2012) seem to be the predominant OM supply during high river discharge and/or high runoff conditions in the Altamaha River estuary. These results confirm the suggestions from previous reports that marsh derived OM is an important, although not dominant source in Georgia estuaries (Teal, 1962; Haines, 1977; Peterson and Howarth, 1987). Although the 2011 wet season pattern seems slightly nonconservative, the measured data points are not significantly different from the conservative mixing line (Fig. 3.2 and Table 3.1b) and was thus characterized as conservatively mixed. Similar conservative mixing patterns were found for both wet seasons (March 2011 and 2012), with $\mathrm{R}^{2}=0.90(\mathrm{p}<0.05)$ and $0.98(\mathrm{p}<0.05)$, respectively. During the wet season, the DOC concentration is diluted linearly with the increase in salinity from the fresh water to the marine end member (Fig. 3.2b). During this time period, the estuary is strongly river-dominated as a result of significant freshwater discharge (Table 3.1a). Although considered as dry season, the river discharge during the sampling event in September 2012 is twice as high as during the dry season in 2010 (Table 3.1a) and local rain (in the estuary itself) was higher by about a factor of ten. Thus, the study area received more freshwater input and land run-off, which resulted in a similar conservative mixing pattern as the two wet seasons (higher precipitation in the upper watershed). The Altamaha River originates in the foothills of the Appalachian Mountains with a high freshwater discharge of $250 \mathrm{~m}^{3} \mathrm{~s}^{-1}$ (Alber and Sheldon, 1999). Therefore, the quality and quantity of organic material is largely influenced by the freshwater transport. A dynamic transportation/interaction of organic compounds exists in the natural river with continuously diluting by bulk water movement (Kilic and Aral, 
2009). As a result, large amounts of freshwater-derived DOM are transported through salt marsh sites down to the estuary, showing a change in concentration by bulk water dilution.

Table 3.1b Contributions (as a percentage) from the salt marsh to DOC and PARAFAC components compared to a conservative mixing scenario

\begin{tabular}{ccccc}
\hline & Aug-10 & Mar-11 & Mar-12 & Sep-12 \\
\hline DOC & $21( \pm 10)$ & $0( \pm 8)^{*}$ & $4( \pm 7)^{*}$ & $8\left( \pm 43^{*}\right)$ \\
C1 & $34( \pm 32)$ & $8( \pm 7)$ & $8( \pm 9)^{*}$ & $-7( \pm 27)^{*}$ \\
C2 & $18( \pm 29)$ & $7( \pm 7)^{*}$ & $-2( \pm 7)^{*}$ & $-10( \pm 30)^{*}$ \\
C3 & $26( \pm 35)^{*}$ & $15( \pm 14)$ & $16( \pm 17)^{*}$ & $-8( \pm 27)^{*}$ \\
C4 & $-55( \pm 50)$ & $-55(35)$ & $-37( \pm 33)$ & $-0.3( \pm 33)^{*}$
\end{tabular}

*A positive value indicates inputs from the salt marshes to the river and a negative value indicates uptake

*not significantly different than the conservative mixing line $(\mathrm{p}>0.05)$ and thus characterized as conservatively mixed

The slope ratio $\left(S_{R}\right)$ of the UV absorption spectra can be used as an indicator of DOM molecular weight (MW) and source (Helms et al., 2008). In this study, the highest $S_{R}$ range (0.91-1.06) was observed during the dry season (August 2010), indicative of DOM of relatively smaller molecular weight compared with the two wet seasons (Table 3.1). During the low river discharge period, DOM is expected to be somewhat less influenced by terrestrial sources, suggesting that the larger $S_{R}$ values could be the result of enhanced contributions of lower MW, marsh-derived DOM combined with a potentially higher degree of microbial- and photo-degradation (Helms et al., 2013). 
However, photo-degradation of this DOM is unlikely significant because of the high level of turbidity in the Altamaha River, limiting light penetration. In contrast, during the wet

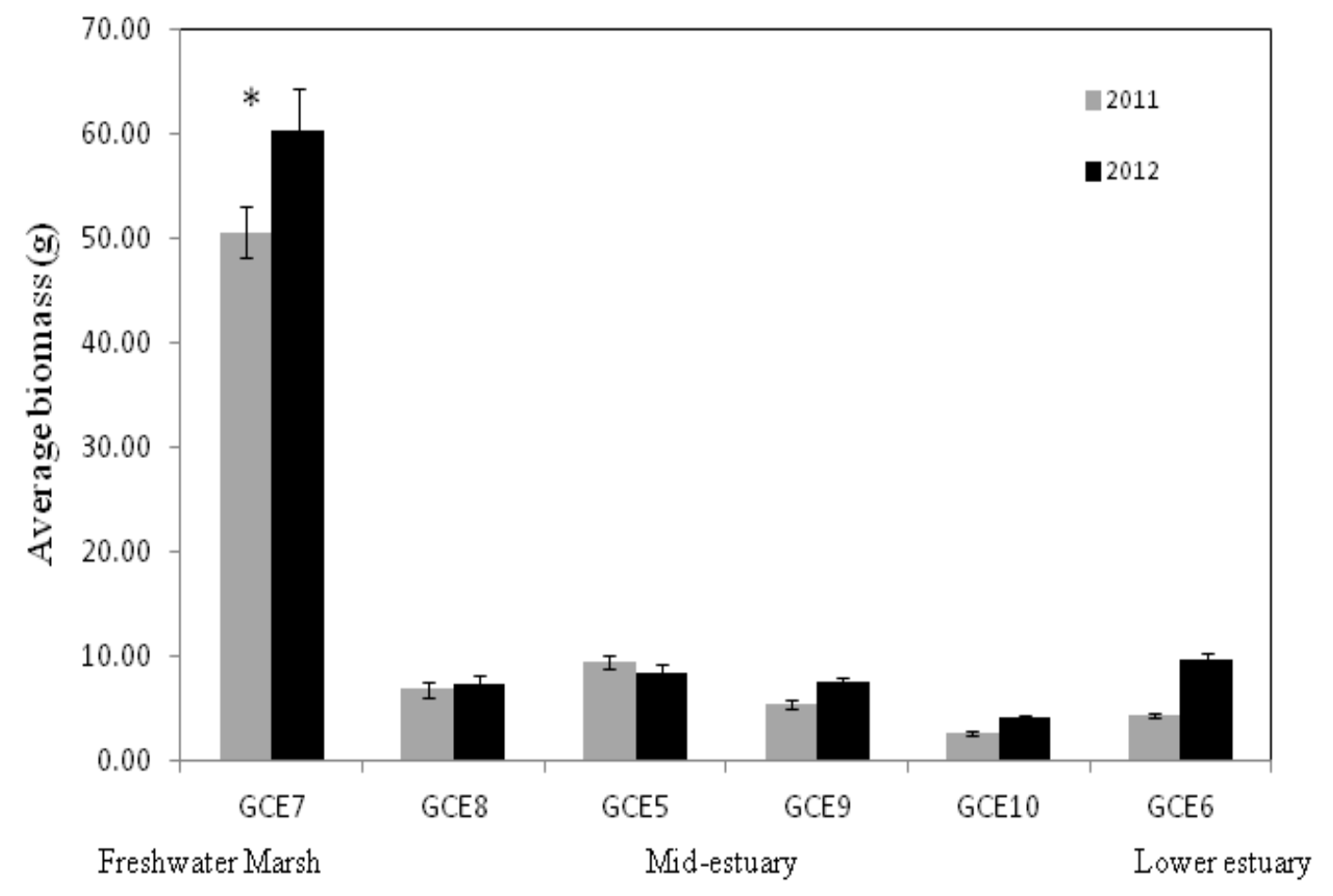

Figure 3.4 Weight of biomass collected during year 2011-2012, data was obtained from the database of on-going Georgia coastal ecosystem long term ecological research program (http://gce-lter.marsci.uga.edu). GCE-LTER stations are indicated as GCE with increasing from upper to lower estuary. Significant difference is indicated using asterisk mark.

season, DOM is as suggested above, primarily originated from freshwater marshes and mainly controlled by hydrological transport, and thus features more humic-like characteristics and likely composed of larger molecules. In agreement, the storm season for 2012 showed the lowest $S_{R}$ range (Table 3.1), which again reflects the temporary enrichment of terrestrial loadings introduced by the large volume of rainfall wash-out, particularly soil-derived $\mathrm{OM}$ and possibly from vegetation via throughfall. In agreement 
with Belzile et al. (2002), who suggested that soil-derived fulvic acid typically featured high molecular weight and aromatic carbon content, our observations on the high molecular weight distribution of DOM during high seasonal rainfall could be a direct impact from storm-induced soil erosion.

The FI, a DOM source index (McKnight et al., 2001), was evaluated for the four sampling events (Table 3.1a), showing the most elevated values for the dry season in 2011 (up to 1.42). This suggests an enrichment of microbial-derived DOM components possibly derived from the marshes. In contrast, the wet seasons and storm season showed relatively lower FI values indicative of DOM enriched in plant/soil-derived components, which is again attributed to the rising river discharge and storm induced land run-off, respectively. Similar finding was reported by Vidon et al. (2008) who showed an inverse correlation between FI and discharge during storms. Therefore, both $\mathrm{S}_{\mathrm{R}}$ and FI values indicate an increase in DOM molecular weight and terrestrial content during rising hydrologic conditions (e.g., wet season and storms). The above-described seasonal and spatial patterns suggest both quality and quantity of DOM in the Altamaha estuary are hydrology-driven with local rainfall causing erosion as another significant driver of DOC export.

\subsubsection{Characteristics of EEM-PARAFAC components}

\subsubsection{EEM-PARAFAC modeling}

On the basis of 87 surface water samples, a four-component PARAFAC model was validated for DOM along the Altamaha River Estuary, covering the fresh water end member, brackish marshes, salt marshes and tidal creeks and the lower estuary. The split 
half validation showed similarity in both excitation and emission loadings, suggesting that the selection of the four-component model in this study was able to capture the bulk features in the measured EEMs (Stedmon and Bro 2003). The four PARAFAC components (Table 3.2; Fig.3.5) were identified as two humic-like components (C1 and $\mathrm{C} 4)$, one protein-like component (C3) and one microbial humic- like component (C2). Component 1 has multiple excitation maximum at 260 and $445 \mathrm{~nm}$ with single emission peak at $460 \mathrm{~nm}$, spectrally corresponding to the humic-like component previously reported as a reduced quinone-like component (Cory and McKnight, 2005). The component $\mathrm{C} 1$ represented 31 to $48 \%$ of the total fluorescence of the four components, and very similar components have been recognized as most abundant components in other ecosystems (Yamashita et al., 2010; Stedmon and Markager 2005). Components C2 and $\mathrm{C} 3$ have more blue-shifted emission peaks compared to $\mathrm{C} 1$. The component $\mathrm{C} 2$ has an emission maximum at $384 \mathrm{~nm}$ and another emission peak around $380 \mathrm{~nm}$, and was similar to the EEM peak assigned as microbial-derived humic-like component by Cobel (peak M; Coble, 1996). The component C3 has an emission maximum around $325 \mathrm{~nm}$, corresponding to the protein-like component (tyrosine; Cobel et al., 1996). The proteinlike component $\mathrm{C} 3$ showed the lowest abundance compared with other three components in surface water. Protein-like component such as C3 in this study were identified in many ecosystem (Yamashita and Tanoue 2003; Cawley et al., 2012), and are commonly reported as derived from microbial activity or planktonic primary productivity. There are three aromatic amino acids (i.e., tyrosine, tryptophan, and phenylalanine) that emit ultraviolet fluorescence (Lakowicz, 2009). The spectral features of C3 were most similar to the reported tyrosine-like fluorescence (T peak; Coble, 1996). Protein-like components 
are generally considered to be freshly produced, and are potentially labile DOM components when subject to biodegradation (Fellman et al., 2008). The component C4 has two excitation maximua in 275 and $405 \mathrm{~nm}$, and an emission maximum greater than $500 \mathrm{~nm}$. The emission peak ( $\sim 500 \mathrm{~nm})$ of $\mathrm{C} 4$ overlapped with components previously identified as soil fulvic acid (Coble et al., 1990). The EEMs spectra of C4 is similar to other terrestrial PARAFAC components previously reported (C3 in Stedmon and Markager 2005; C10 in Cory and McKnight, 2005) which are presumably related to soil or terrestrial particulate derived organic matter (Stedmon et al., 2003; Singh et al., 2010; Yamashita et al., 2008).
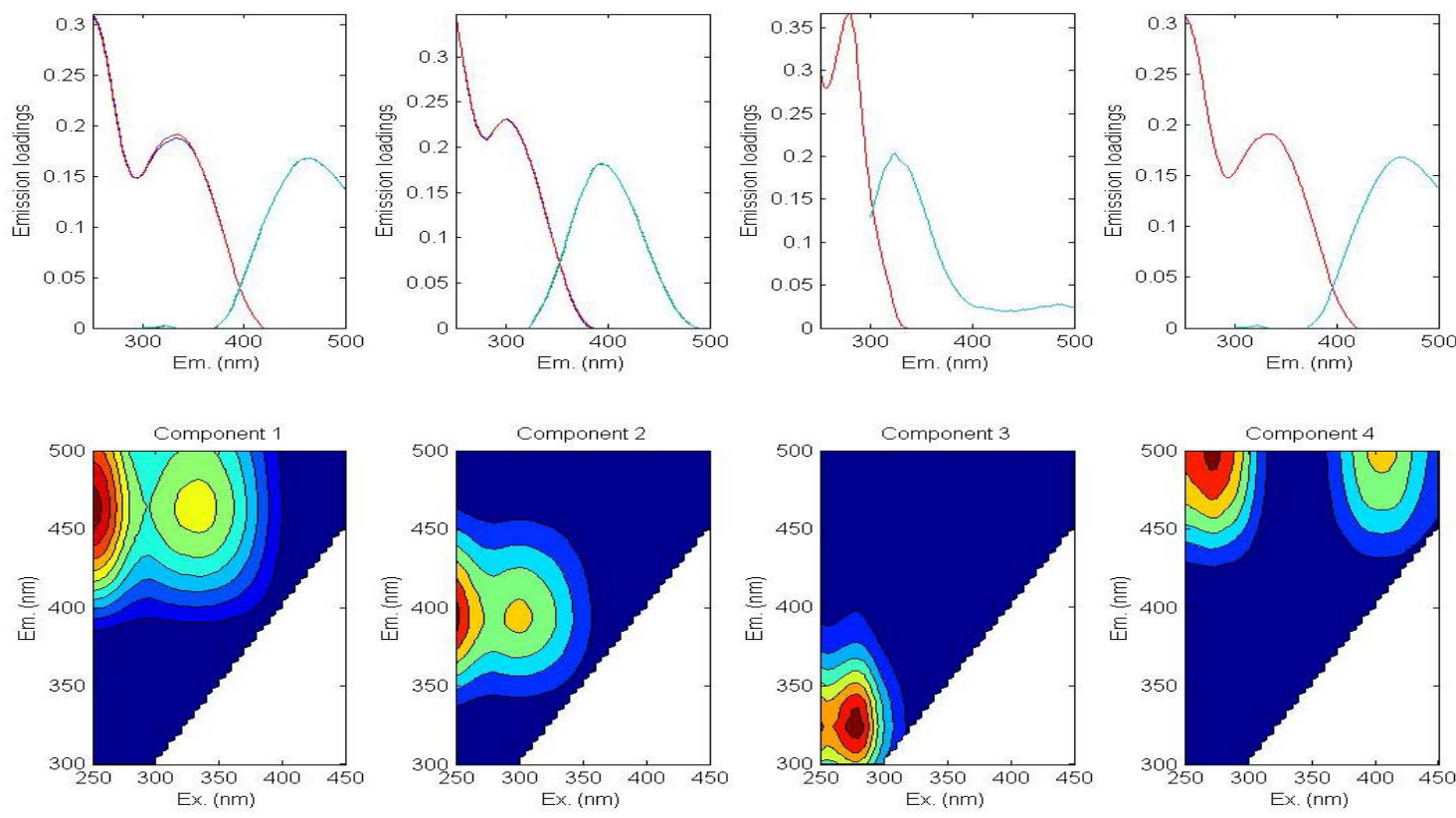

Figure 3.5 PARAFAC components in Altamaha River ecosystem. Component 1 is humiclike component, component 2 is microbial humic-like component, component 3 is protein-like component and component 4 is a fulvic acid-like component. 
Table 3.2 Characteristics of the four PARAFAC components in the Altamaha estuary

\begin{tabular}{|c|c|c|c|c|}
\hline Component & Ex (nm) & $\operatorname{Em}(\mathrm{nm})$ & Sources from references & This study \\
\hline $\mathrm{C} 1$ & $260(335)$ & 464 & $\begin{array}{l}\text { C1(Yamashita et al. 2010; Stedmon and Markager } \\
\text { 2005) } \\
\text { Ubiquitous humic-like; terrestrial }\end{array}$ & $\begin{array}{l}\text { Ubiquitously abundant in } \\
\text { terrestrial soil and plants }\end{array}$ \\
\hline $\mathrm{C} 2$ & $250(300)$ & 384 & $\begin{array}{l}\text { Microbial humic like component, M peak } \\
\text { (Coble,2007) } \\
\text { C peak (Coble2007);C3( Stedmon and Markager } \\
\text { 2005). } \\
\text { UVA marine humic like }\end{array}$ & $\begin{array}{l}\text { Abundant in spartina leachat } \\
\text { Intermediate product during } \\
\text { bioproduction }\end{array}$ \\
\hline $\mathrm{C} 3$ & 275 & 324 & Protein-like(Tyrosine); T,N peak(Coble et al.,1996) & $\begin{array}{l}\text { Abundant in plant leachate } \\
\text { bioactive; prone to biodegradation }\end{array}$ \\
\hline $\mathrm{C} 4$ & $275(405)$ & 500 & $\begin{array}{l}\text { C5(Yamashita et al 2010), } \\
\text { Soil-derived fulvic acid-type } \\
\text { biogeochemical processing of terrestrial POM }\end{array}$ & $\begin{array}{l}\text { Abundant in soil leachate } \\
\text { prone to bioproduction }\end{array}$ \\
\hline
\end{tabular}




\subsubsection{Distribution of PARAFAC components along the Altamaha River estuary}

The abundance of EEM-PARAFAC components showed similar spatial variations as observed for the DOC along the Altamaha River estuary. Similar to the variation trend of DOC concentration, all four components showed a general pattern of decreasing abundance with increasing salinity. For the dry season (2010) sampling, the PARAFAC components showed a non-conservative pattern, similar to that of the DOC. However, in contrast to the bulk DOC, some non-conservative mixing behavior was observed during both the storm season (2012) and the two wet seasons (Table 3.1b). For the dry season in 2010 the non-conservative mixing was indicative of significant DOM inputs, with the abundance of PARAFAC components above the conservative mixing line between the salinity range of 5 25, attributed to marsh inputs. In contrast, the non-conservative mixing for the storm season 2012 and the two wet seasons were quite different: For these, although the EEM-PARAFAC components were found decreasing nearly linearly along the salinity gradient $\left(\mathrm{R}^{2}\right.$ of each correlation line is above $\left.0.9, \mathrm{p}<0.01\right)$, some deviations from this conservative mixing were also observed. During the two wet seasons, while most PARAFAC components behaved linearly with increasing salinity, the humic-like C4 component showed non-conservative mixing patterns (Table $3.1 \mathrm{~b}$ ), potentially suggesting some removal process during transport.

Since the C4 component was previously reported as a soil derived, fulvic acidtype component, which is presumably resistant to microbial degradation (Olefeldt et al., 2013), this loss seems unlikely as a result of biodegradation, and thus could be related to DOM flocculation as salinity increases. Even during the dry season (2010), C4 did not 
show significant inputs from the marsh environment and its distribution along the salinity gradient suggests removal from the DOM pool (Table 3.1b). During the storm season of 2012 the distributions were a bit different again. All PARAFAC components presented a non-conservative mixing at very low salinity $(0-2)$ where they were above the theoretical, conservative mixing line, suggesting an important FDOM source in the freshwater marsh environment. Although seemingly subject to DOM removal (slightly below conservative mixing line) the distributions were mainly linear with no significant difference between measured data points and conservative mixing line (Table 3.1b).

The oligo/meso-haline zone of river-dominated estuaries has recently been shown to be very dynamic (Maie et al., 2014), where hydrological conditions were found to strongly affect DOM sources and fate. Interestingly, C4 generally showed the least abundance among the four PARAFAC components except for storm season. During the storm season, the fluorescence intensity of $\mathrm{C} 4$ was significantly higher than $\mathrm{C} 3(\mathrm{p}<0.05)$. The presence of $\mathrm{C} 4$ as a likely soil-derived fulvic-acid like component implied significant export from land run-off into the DOM pool. Similar to the PARAFAC results, in situ optical measurements of DOM during the summer storm period also revealed significant changes of DOM optical properties with optical properties (e.g. SUVA,FI and slope ratio) shifting toward aromatic, high molecular weight DOM derived from terrestrial sources (Saraceno et al., 2009). The mechanism of the change in DOM compositional profile induced by storms was described by Vidon et al. (2008). Briefly, during storm events there is a shift in the source of DOM from mineral soil layers to surficial soil layers enriched in aromatic substances. In terms of PARAFAC composition, such a shift in DOM sources during storms is reflected by the enrichment in the soil-derived C4 
component. Combined with previously described optical properties and DOC concentration (3.3.1), our EEM-PARAFAC results further confirm that after storm events, DOM quantity and quality are drastically changed. Compared with the Satilla River, another major river on the Georgia coast, the freshwater flow rate of the Altamaha River was reported to be an order of magnitude higher (Alber and Sheldon, 1999), and thus freshwater sources of DOM seem to overwhelmingly dominate in the Altamaha River estuary, damping the fluoresce signal from adjacent salt marshes. A previous study by Dai et al., (2007) on OM cycling in the Altamaha estuary sediments suggested that terrestrial sources dominate $(>80 \%)$ at most of their study sites. Our study showed a similar result for the dissolved organic matter pool in surface water. Marsh-derived inputs were however observed to be important during the dry season and within the tidal creeks during all seasons.

The variation of DOM composition in rivers and estuaries can be highly variable as driven by hydrological variations (Vidon et al., 2008; Townsend-Small et al., 2011). In agreement, our results suggested that the distribution of DOM PARAFAC components in the Altamaha estuary varied during different water discharge conditions. Generally, this ecosystem is freshwater-dominated which result in humic-enriched DOM (76\%) input likely derived from the upper watershed, freshwater marshes. Apart from the precipitation driven hydrologic conditions, the DOM distribution is subject to tidal forces as well especially for the streamside marsh. Humic substances (e.g., lignin phenols) are transported into the river system after being trapped on the salt marshes for one or two tidal cycles (Moran et al., 1991). However, the labile fraction of can be consumed by the marsh bacteria during the residence time prior to reaching to the mainstream water body 
of the estuary. For example, polysaccharides are easily utilized by bacteria five times more quickly than humic components (Benner et al., 1987) . Consequently, the biorefractory fraction of DOM (e.g., humic-like component) is able to accumulate and retain in tidal creek water. The compositional profile of salt marsh derived DOM may thus be considerably modified compared with fresh exudates/leachates from salt marsh plants. The next section will compare the DOM composition between fresh plant leachate and surface water DOM (3.3.2.3)
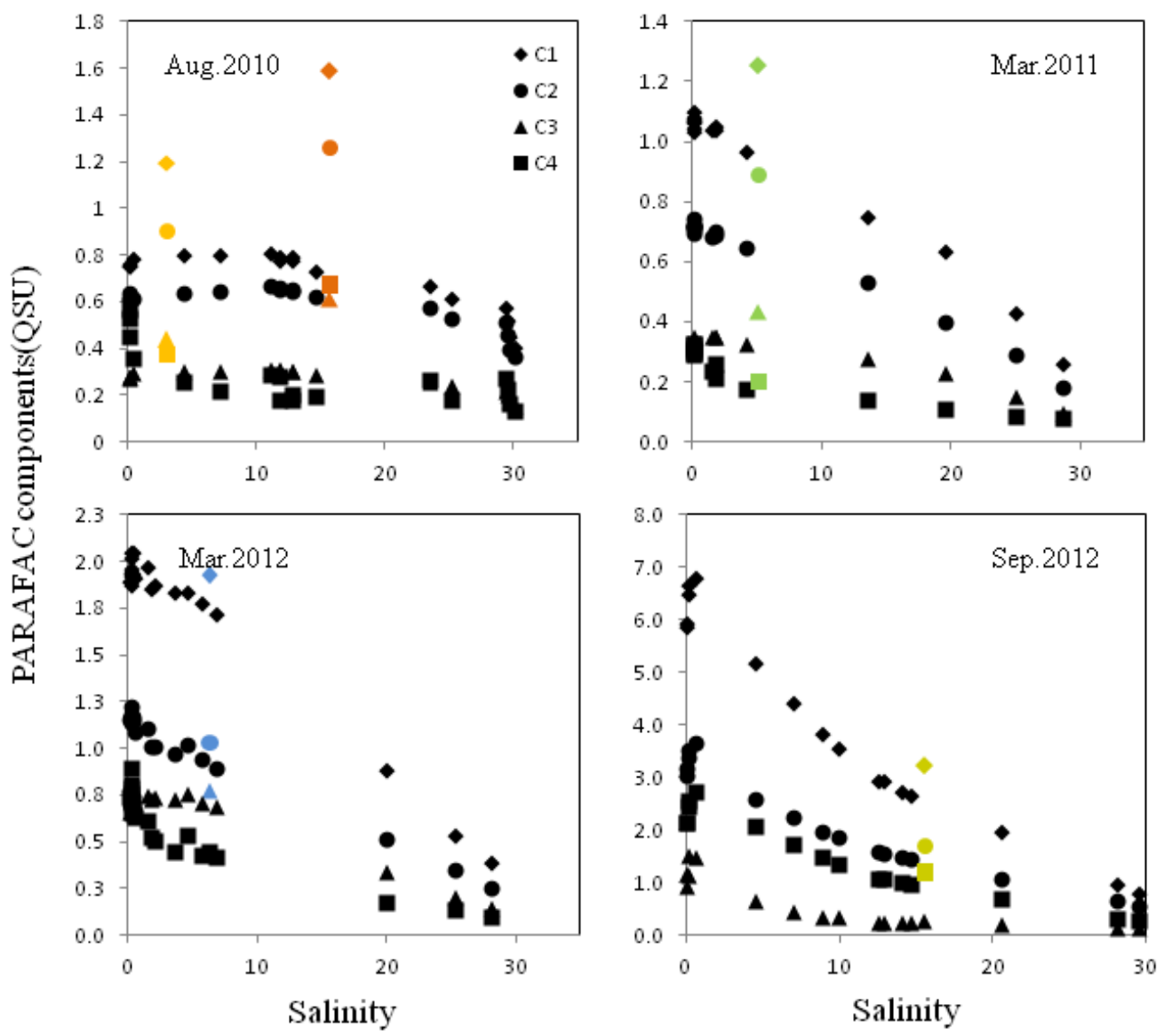

Figure 3.6 Spatial and seasonal variation of PARAFAC components based on the fluorescence intensity of PARAFAC components (QSU) indicating by samples collected in Aug. 2010 (dry season) and Mar. 2011 (Wet season). Colored dots indicated samples from salt marsh creeks 


\subsubsection{Sources and reactivity of the PARAFAC components}

Sources of DOC in the oligohaline area of river-dominated estuaries can be strongly influenced by hydrology and local environmental conditions (Maie et al., 2014). In addition to vegetation leaching, bacterial decomposition of salt marsh detritus has been known as another major pathway of humic substances transfer into the bulk DOC pool (Moran and Hodson, 1994). In estuaries such as the Altamaha, DOM can also be produced through plasmolysis of salt marsh plants (Morris et al., 1978). In an attempt to understand the potential sources and characteristics of the above-described PARAFAC components, we conducted a series of leaching experiments on representative organic source materials including plants (Cypress, Spartina and Juncus) and soils (freshwater, brackish and salt marshes) in the studied region. The EEM data obtained from the biomass and soil leachate were fitted to the 4-component PARAFAC model developed for the Altamaha River estuarine surface water DOM. Residual peaks in biomass and soil leachate were observed in protein-like fluorescence region (Ex/Em: 275/305 nm) and microbial humic-like fluorescence region (Ex/Em: 410/468 nm), which was not observed in surface water DOM. They are suggested to be labile, highly reactive component that do not accumulate in natural environment.

The total amounts of DOC (mg C g ${ }^{-1}$ dry weight) leached from plants and soils were variable among sample types. Cypress leachate contained the highest organic $\mathrm{C}$ content (normalized to dry weight) followed by Spartina and Juncus leachate (Table 3.3). The UV-Vis and fluorescence measurements also showed the highest amount of CDOM $\left(\mathrm{Abs}_{254}\right)$ and FDOM (Fmax/DOC) in cypress leachate compared with other biomass 
(Table 3.3). The DOC leaching efficiency of cypress is significantly higher than Juncus and Spartina, which could semi-quantitatively explain the higher DOC loading at the freshwater sites compared with the salt marsh sites. However, while leaching experiment alone cannot quantitatively assess the DOM produced by biomass/soil without the calculation of biomass coverage, it can provide valuable data on DOM sources based on compositional similarity.

An important pathway for the production of plant-derived DOM is through the leaching of vegetation (submerged and throughfall). The average carbon leaching rate of hard cord marsh grass was reported to be $200 \mathrm{~g}(\mathrm{dry} \mathrm{wt})^{-1} \mathrm{~h}^{-1}$ in Georgia salt marsh (Gallagher et al., 1980). Compared with detritus degradation, plant leaching is a relatively faster pathway contributing to the "fresh" DOM pool than decomposition. In contrast, the decomposition of vascular salt marsh plant tissues tends to contribute more refractory humic-like components which make up of $66 \%$ of the total dissolved humic substance (Moran and Hodson, 1994). In addition, previous studies suggested that carbon leaching rate of Spartina alterniflora salt marshes reached peak during summer (Turner, 1993), which could explain the salt marsh export observed during August 2010 to be more significant than March 2011 and 2012. Our EEM-PARAFAC studies on the leached DOM confirm that plant leachates indeed produced more of the protein-like $\mathrm{C} 3$ relative to humic-like components. Table 3.3 and Figure 3.7 show that plant leachates contained significantly higher abundance $(\mathrm{p}<0.01)$ of the protein-like component compared with soil leachates and surface water DOM. In fact, $\mathrm{C} 3$ accounted for $75 \%$ in cypress leachate, $28 \%$ in Spartina leachate and $47 \%$ in Juncus leachate. Soil and ground water only contained $7 \%$ and $5 \%$ of this component, respectively, while an average of $13 \%$ in 
surface water DOM was observed. The relative abundance of C3 in surface water could be the result of mixing from both biomass and soil sources. Based on previous reports a significant fraction of this locally produced, protein-like component, could likely be utilized by heterotrophic bacteria (Turner, 1978; Fellman et al.,2008; Balcarczyk et al.,2009). Therefore, this potentially labile portion of DOM could be degraded at least partially once released into surface waters as plant leachate.

As C4 has previously been described as a fulvic-acid type component associated with soil-derived and particulate organic matter, not surprisingly our soil leaching experiment showed higher relative abundance of $\mathrm{C} 4$ component compared to the marsh plant leachates (Table 3.3). The C4 content in leachates from cypress was however, quite significant. Both $\mathrm{C} 1$ and $\mathrm{C} 4$ were found to be ubiquitous to all samples but most abundant in soil leachate with $45 \%$ and $15 \%$ of total fluorescence, respectively. Consequently, we observed enhanced C4 fluorescence during storm season as a result of the soil run-off (3.3.2.2) and possibly throughfall in the cypress-dominated areas of the upper watershed. Lastly, C2 as the microbial humic-like component showed the highest relative abundance in Spartina leachate followed by soil leachate (Table 3.3). Therefore, the salt marsh DOM export observed during August 2010 could be partially attributed to the Spartina and would expectedly feature more C2 loading, which was indeed reflected in the distribution of PARAFAC components described in section 3.3.2.2. ). 
Table 3.3 DOC concentration and optical properties of plant/soil leachate

\begin{tabular}{cclll}
\hline Sample type & Spartina & Juncus & Cypress & Soil \\
\hline C content(mg C.g $\left.{ }^{-1}\right)$ & $3.91 \pm 0.13$ & $9.86 \pm 0.43$ & $25.19 \pm 1.14$ & $1.95 \pm 0.05$ \\
Abs(254) & $1.84 \pm 0.06$ & $0.78 \pm 0.18$ & $3.61 \pm 0.81$ & $0.14 \pm 0.04$ \\
Fmax (QSU.mg.L $\left.{ }^{-1}\right)$ & $0.26 \pm 0.01$ & $0.43 \pm 0.12$ & $45.42 \pm 1.74$ & $0.44 \pm 0.08$ \\
C1(\%) & $23.67 \pm 0.32$ & $27.11 \pm 0.78$ & $27.32 \pm 0.71$ & $45.37 \pm 0.32$ \\
C2(\%) & $37.93 \pm 0.57$ & $24.35 \pm 0.06$ & $23.52 \pm 0.23$ & $32.61 \pm 0.20$ \\
C3(\%) & $28.43 \pm 0.33$ & $47.18 \pm 0.77$ & $47.67 \pm 0.12$ & $6.88 \pm 0.03$ \\
C4(\%) & $9.97 \pm 0.55$ & $1.35 \pm 0.30$ & $24.83 \pm 0.11$ & $15.14 \pm 0.13$ \\
$\delta^{13}$ C(\%) & $-19.69 \pm 0.12$ & $-26.61 \pm 0.51$ & $-28.04 \pm 0.59$ & - \\
& & & & \\
\hline
\end{tabular}



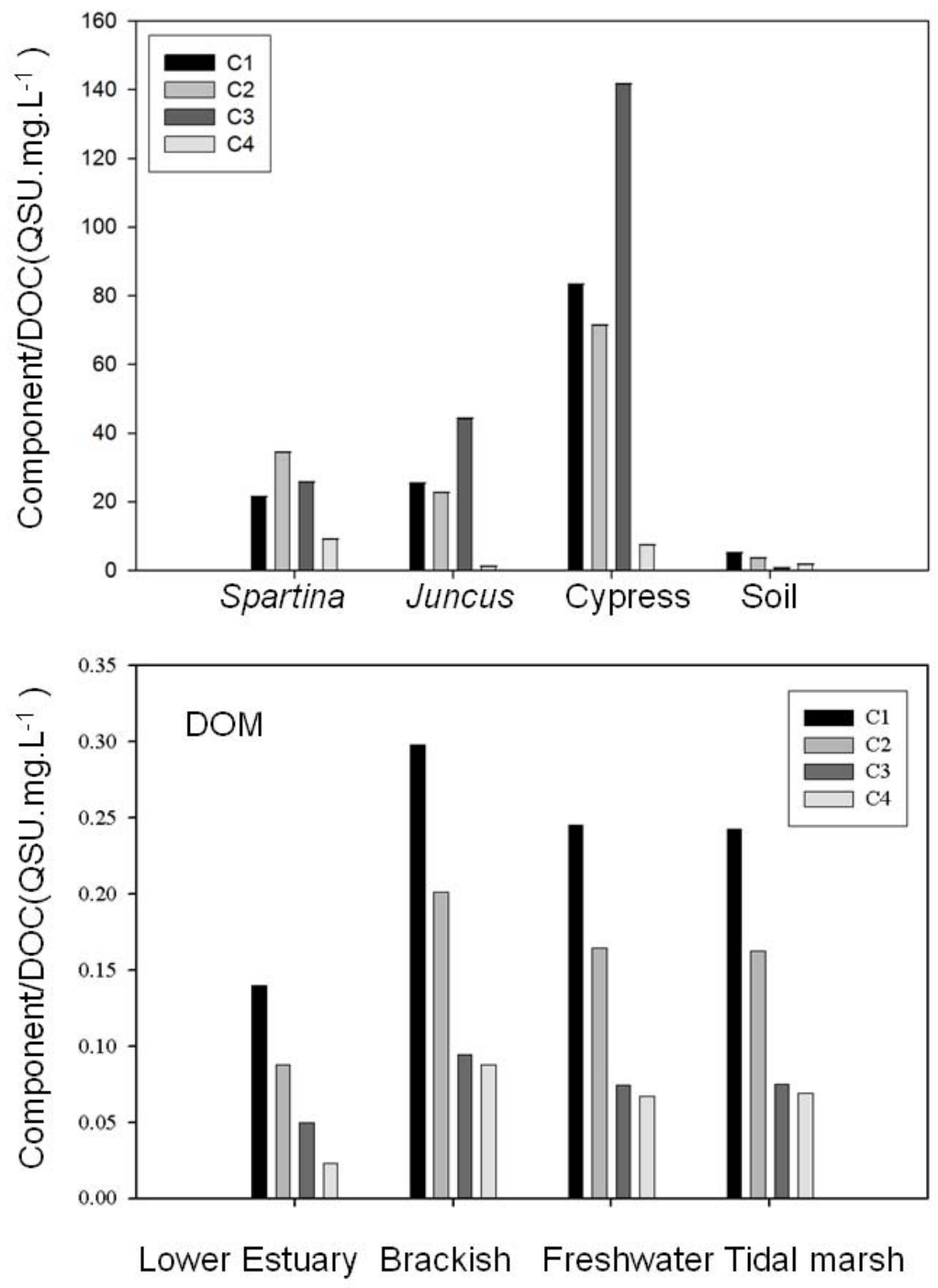

Figure 3.7 PARAFAC compositions of surface water DOM, plant and soil leachates

As it showed in Fig. 3.8, C3 as the potentially labile component showed the most significant change in its relative abundance (by $\sim 20 \%$ ) compared with humic-like components $(<2 \%)$. Our dark incubation showed a general consumption of C3 by microbial activity. The other three components representing the humic substances were 
all generated during the $23 \mathrm{~d}$ dark incubation period. $\mathrm{C} 2$ has been reported as the intermediate product generated within the microbial loop (Coble, 2007), and was found to be constantly generated during the $23 \mathrm{~d}$ incubation. It is possible that $\mathrm{C} 2$ generated through plant leaching, particularly Spartina, can be microbially enhanced and therefore found as the second most abundant component in surface water DOM (Fig. 3.7). The C4 component as the soil fulvic-acid generally showed higher degree of bio-recalcitrance compared with tyrosine and tryptophan-like component (Yamashita et al., 2010). Our incubation results showed a slight increase in C4 (by 1.5\%) during the microbial reworking process. However, the overall increase in humic-like PARAFAC components was only in the range of 1.2 to $1.5 \%$, suggesting that this microbial 'humification' is limited on the time scale of the incubation and likely insignificant compared to the soil and plant litter leaching contributions. As suggested by previous study (Chen and Jaffé 2014), bio-humification transformation was observed for plant leachate, which is suggested to be more evident compared to biodegradation (Chen and Jaffé 2014) thus PARAFAC composition can be significantly altered towards humic-enriched features through microbial rework (Chen and Jaffé 2014; Wilson and Xenopoulos 2009). 


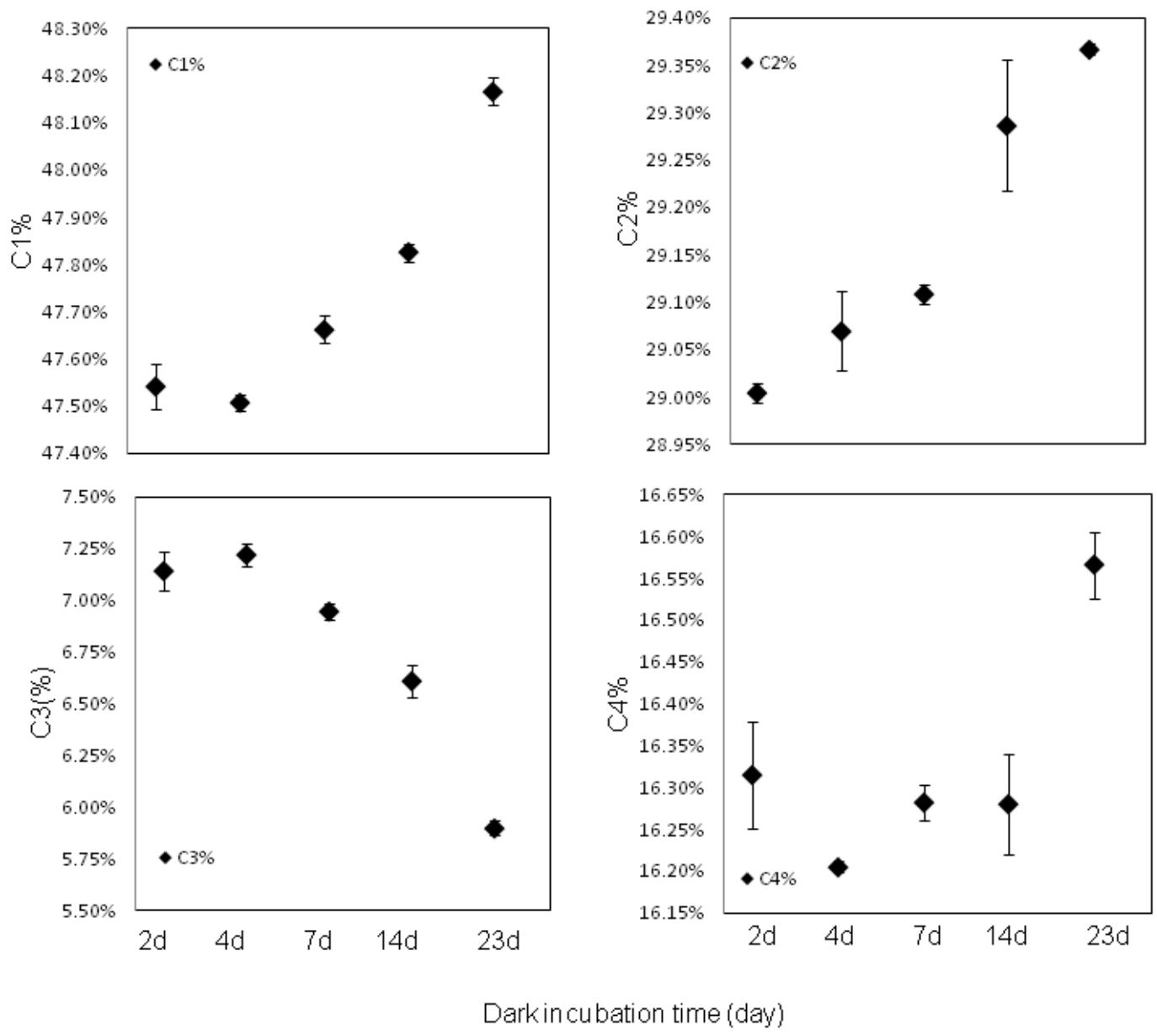

Figure 3.8 Variation of PARAFAC components during the dark incubation

\subsubsection{Principal component analysis}

Principal component analysis (PCA) based on the relative abundance of PARAFAC components was used to statistically evaluate DOM dynamics (Fig. 3.9 PC1 scores changed markedly along the salinity gradient for all seasons, but to different degrees (Fig.3.10a). DOM from the freshwater site showed stronger terrestrial signature with more enriched humic-like substances (C1), and thus showed PC1 scores shifted towards the negative side (Fig.3.9). 


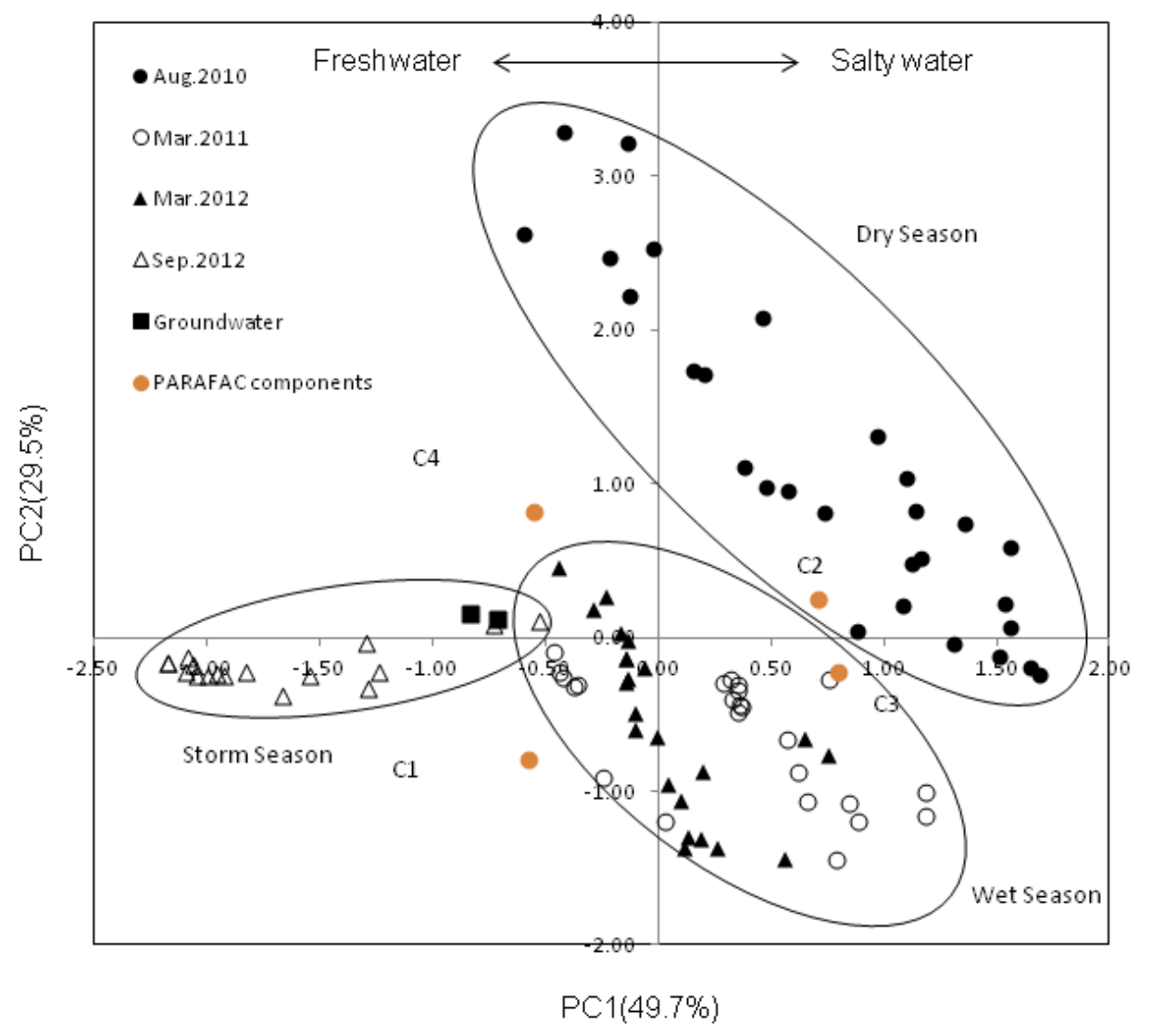

Figure 3.9 Principal component analysis plot based on the relative abundance of EEM-PARAFAC components

Vegetation type is characteristically distributed along the salinity gradient in the Altamaha River estuary with cypress dominating the freshwater site, Spartina alterniflora primarily in salt marsh and Juncus roemerianus in brackish/salt marshes (Higinbotham et al., 2004). Therefore, $\mathrm{PC} 1$ is likely controlled by DOM sources. It is unclear at this time what the relative contribution of biomass sources $v s$. soil organic matter sources is. Based on the leaching experiments, the plant leachates were enriched in $\mathrm{C} 3$ but also generated significant amounts of humic-like components (e.g., F in Spartina leachate). DOM within the brackish marsh region are strongly influenced by the addition of protein-like 
component $\mathrm{C} 3$ and microbial humic-like component $\mathrm{C} 2$ (Fig. 3.9 and Fig. 3.10a), possibly due to the leaching of both freshwater plants (e.g., cypress) and salt/brackish mash plants. Furthermore, plankton-derived inputs towards the lower estuary region can possibly contribute to the protein-like fluorescence (Rochelle-Newall et al., 2002). Spartina lechate contained more microbial humic-like component (C2) relative to protein-like component (C3) (Table 3.3). This to some extend also confirmed our previous suggestion that during the dry season, more salt/brackish marsh-derived DOM is accumulated in surface water with featured PARAFAC component (C2). The soil leachates however, were enriched in the humic-like components at the expense of $\mathrm{C} 3$ (Table 3.3 and Figure 3.7). Thus, the variability of the DOM composition may in part be attributed to the changing of vegetation and/or soil OM patterns along the Altamaha River estuary. In addition to the salinity-dependent source change, PC1 scores of different seasons were clustered distinctly separately (Fig. 3.10a), suggesting hydrologydependent source change as the second regulating factor for DOM variability (Fig. 3.9 and 3.10). PC1 scores for the dry season significantly shifted to more positive values while the storm season featured most negative $\mathrm{PC} 1$ values. The two wet seasons were clustered together and showed intermediate $\mathrm{PC} 1$ values in between the dry and storm season. As river discharge and precipitation both vary on a seasonal basis, more terrestrial sources will be introduced by higher loading of freshwater input (terrestrial humic-like components $\mathrm{C} 1$ and $\mathrm{C} 4$ ), while during the low river discharge, $\mathrm{OM}$ exported from salt marshes is prone to accumulation and thus featured different compositional characteristics (enriched in salt marsh derived components C2 and C3). The storm season showed the most negative PC1 values, with clear shift to the loading of fulvic acid type 
component C4 (Fig.3.8), which is likely originated from soils and terrestrial plants (3.3.2.2). This again suggests a strong storm-induced change in DOM composition. Groundwater DOM collected from the northeastern region of the estuary (Sapelo Sound) clustered with storm season, which are mostly controlled by the loadings of ubiquitous humic-like and fulvic acid-type components. This reflects a terrestrial-derived source in groundwater DOM and active groundwater-soil interaction. Overall, the change of OM source driven by salinity stress and hydrology account for the major variations in the observed DOM characteristics.

Compared with PC1, PC2 accounts for 30\% of the variability and showed less seasonal variations, with the four sampling events more clustered together (wet, dry and storm, Fig. 3.9b). Both PC1 and PC2 appeared to correlate with salinity changes (Fig. 3.10) but are opposite to each other. $\mathrm{C} 1$ and $\mathrm{C} 3$ showed the most negative $\mathrm{PC} 2$ values (Fig.3.9). C3 as a protein-like component represents recently produced fluorophores and is generally considered as bioavailale substance, while $\mathrm{C} 4$ as humic-like component is considered not subject to biodegradation. The results of dark incubation confirmed that C3 was consumed by microbial activities during a 23d incubation period (Fig.3.8). C2 and $\mathrm{C} 4$ on the other hand were produced during the dark incubation (Fig.3.8). With $\mathrm{C} 2$ and $\mathrm{C} 4$ at positive side vs. $\mathrm{C} 1$ and $\mathrm{C} 3$ at negative side, $\mathrm{PC} 2$ might possibly be indicative of the degree of DOM degradation. Dry season (2010) showed the highest PC2 scores compared with the two wet seasons and storm season (Fig.3.8), suggesting more "degraded" humic-like components (C2 and $\mathrm{C} 4)$ were produced and accumulated during the low river discharge. As mentioned above (i.e. non-conservative mixing), the DOM during the dry season likely receives contributions of DOM produced through the 
microbial decomposition of marsh plants with enriched microbial humic-like component (C2). Higher PC2 values during dry season also coincided with higher $\mathrm{S}_{\mathrm{R}}$ (Table 3.1), confirming that DOM in the dry season is more degraded with smaller molecules and/or derived from emergent plants vs. vascular plants from the freshwater swamp. Less freshwater flushing during dry season allowed longer residence time in the water column for sufficient accumulation of degraded DOM. Both $\mathrm{S}_{\mathrm{R}}$ and PC2 values are the reflection of DOM characteristics driven by microbial degradation. Interestingly, there is a drop in PC2 values in the salinity range of 5-20 for both wet seasons (Fig. 3.9b), indicative of DOM with relatively more protein-like content (C3). This enrichment in the freshly produced, protein-like component within the brackish-salty water is possibly results of DOM export from salt marsh plant leachates. Considering that the protein-like $\mathrm{C} 3$ was found to be the most bioavailable component, both $\mathrm{S}_{\mathrm{R}}$ and PC2 might be more likely indicative of marsh derived DOM than actual microbial degradation of exported DOM due to extended residence times. 


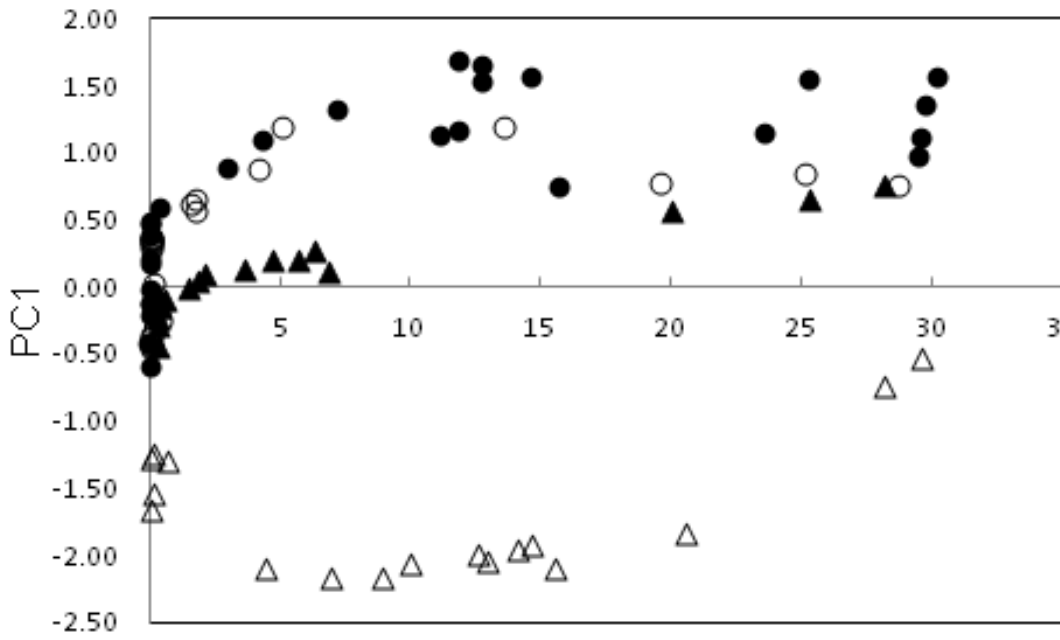

- Dry Season (Aug 2010)

O Wet Season (Mar.2011)

$\Delta$ Storm Season(Sep.2012)

A Wet Season (Mar.2012)

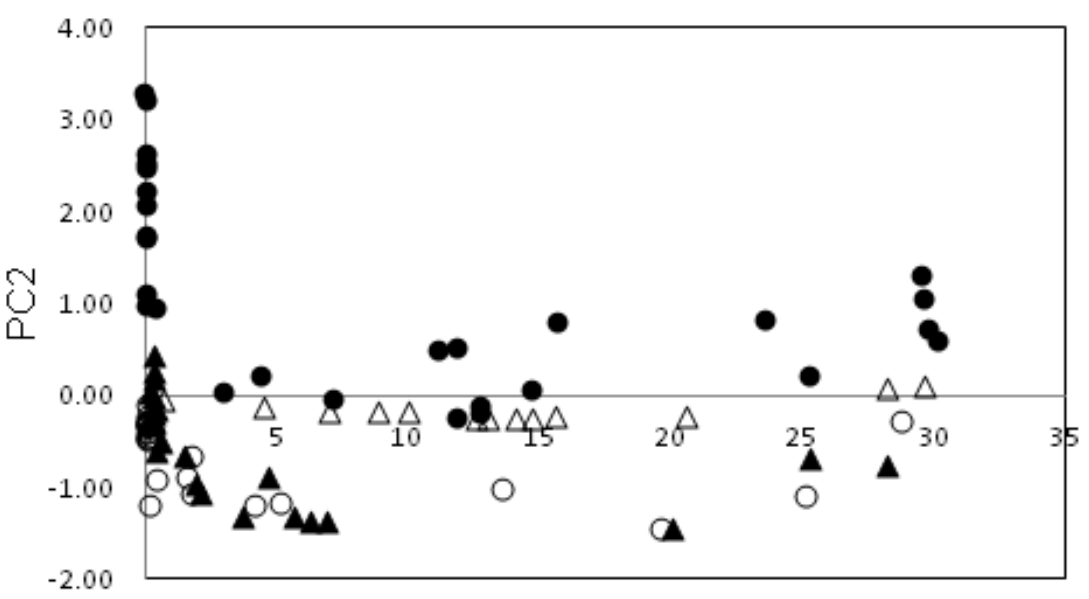

Freshwater

Seawater

Salinity

Figure 3.10 Graphical representations of $\mathrm{PC} 1$ and $\mathrm{PC} 2$ values varied with salinity gradient during wet and dry seasons

\subsubsection{Source characterization by stable C isotope analyses}

The $\delta^{13} \mathrm{C}$ values of DOC did not show any significant seasonal variation ( $\left.\mathrm{p}>0.05\right)$ with an average $\delta^{13} \mathrm{C}$ of $-27.9 \pm 0.3 \%$ during the wet season (March 2012) and $-27.5 \pm$ $0.2 \%$ during the storm season (September 2012). The $\delta^{13} \mathrm{C}$ variations were also observed 
on a spatial scale for both seasons with significantly more enriched values in the salt marsh portion of the estuary compared to the brackish and freshwater marsh sections (Table 3.4). DOM in the freshwater sites exhibited the most depleted value and became more enriched along salinity transect with the most depleted values in the mid-salinity range; and more enriched value towards the marine lower estuary (Fig.3.11). The distribution of $\delta^{13} \mathrm{C}$ along the salinity gradient did not represent a simple two-end member mixing process, but was characteristic of non-conservative mixing. The isotopic values for the Altamaha River biomass feature distinct signatures (Table3.3). Cypress representing the freshwater vegetation showed the most depleted isotopic value ($28.04 \%$ ) followed by the brackish marsh vegetation Juncus (-26.61\%o). Spartina, a C4 plant, showed the most enriched isotopic values (-19.69\%o). It has been reported that riverine DOC- $\delta^{13} \mathrm{C}$ is very different from DOC leached from salt marsh plants (Coffin et al., 1989). The depleted $\delta^{13} \mathrm{C}$ values (below conservative mixing line) around the midsalinity likely reflects the contribution of DOM input from the brackish marsh vegetation (Juncus), while at highest salinities the combination of salt-marsh derived and plankton derived DOC may result in the more enriched isotopic signatures. As the dominant vegetation in the Altamaha brackish marsh, Juncus comprised approximately $45 \%$ of the vegetation species (Higinbotham et al., 2004). Compared with marine planktonic algae $\delta^{13} \mathrm{C}\left(-22 \%\right.$ ) (France 1995) in coastal environments, Juncus showed more depleted $\delta^{13} \mathrm{C}$ value $(\sim-27 \%)$, similar to that of other typical terrestrial C3 plants $(-27.4 \%)$ (Cloern et al., 2002). The $\delta^{13} \mathrm{C}$ variation trend along salinity gradient suggested a three end- member mixing of DOM in the Altamaha estuary where Juncus acted as the external source in the isotopic depletion of DOM in the mid-estuary. Although DOC and EEM-PARAFAC 
components along the salinity gradient suggest that in the Altamaha River estuary, freshwater-derived organic matter sources are dominant, the $\delta^{13} \mathrm{C}$ data suggest that input from adjacent marshes, particularly from Juncus may also be significant.

Table.3.4 $\delta^{13} \mathrm{C}$ analysis of surface water DOM in salinity zones along the Altamaha River transect

\begin{tabular}{lccc}
\hline & \multicolumn{3}{c}{ Mean $\delta^{13} \mathrm{C}(\%)$} \\
\cline { 2 - 4 } & Fresh & Brackish & Estuary \\
\hline Mar.2012 & $-28.5 \pm 0.1$ & $-28.3 \pm 0.3$ & $-25.8 \pm 0.5$ \\
Sep.2012 & $-28.3 \pm 0.0$ & $-27.6 \pm 0.1$ & $-25.7 \pm 0.8$ \\
\hline
\end{tabular}

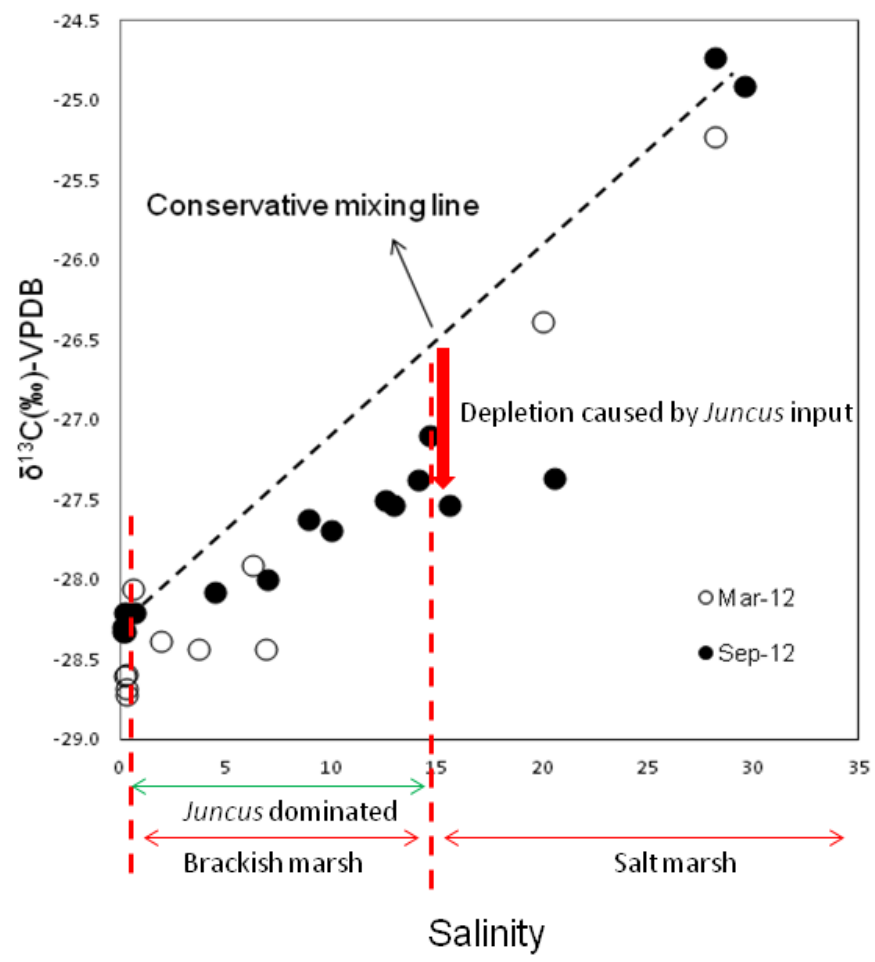

Figure 3.11 variation of DOC- $\delta^{13} \mathrm{C}$ along the Altamaha estuary during wet season (Mar.2012) and storm season (Sep.2012) 


\subsection{Conclusions}

Both optical parameters and isotopic values suggested that salt marshes in the Altamaha River estuary are not the dominant sources of DOC, but affect the distribution pattern of DOM quality and quantity. Changing origins of DOM from river-derived to marsh-derived will have an impact on nearshore microbial community (Hopkinson, 1985). Salt marsh environments, adjacent to river-dominated estuaries are characterized by complex food web where marsh derived OM serves as much important energy source compared to other sources (Peterson et al., 1986). The production of DOM through leaching of plant is a well-defined mechanism (Barlocher, 2005), and considerable amounts of DOM are derived from leaf litter in oligo/meso-haline zone of coastal rivers (Meyer et al., 1998; Abelho, 2001; Maie et al., 2014). In this study, the leaching experiments of marsh vegetation provided some indication of a biomass-based origin for the differences in DOM PARAFAC composition. Although it did not lead to the quantitative conclusion of DOM contribution from potential sources, it provided clues for dynamics of DOM exported from salt marsh to water column. Our experiment showed proteins prevalence in plant leachate, which was also found in other leaching study plant leachate (Cuss and Guéguen, 2012). Such labile components can be removed from the water column through biodegradation more easily than more aromatic, humic-like DOM, which is enriched in soil-derived leachates and through microbial processing of DOM in tidal creeks. While the quantitative estimations of the DOC flux from salt marshes to river-dominated estuaries remains challenging, our study showed the effects on the seasonal and spatial variations of DOM characteristics, resulting from hydrological changes, species diversity and richness along the salinity gradient and modification 
through microbial processing. The seasonal DOC contributions from the salt marshes in the Altamaha River estuary estimated here ranged from $4 \%$ to $21 \%$. 


\section{REFERENCES}

Alber, M., Sheldon, J., 1999. Use of a date-specific method to examine variability in the flushing times of Georgia estuaries. Estuarine, Coastal and Shelf Science 49, 469-482.

Anderson, W.T., Fourqurean, J.W., 2003. Intra-and interannual variability in seagrass carbon and nitrogen stable isotopes from south Florida, a preliminary study. Organic Geochemistry 34, 185-194.

Anderson,D.T., 2001. Spectrofluorometric characterization of dissolved organic matter for indication of precursor organic material and aromaticity. Limnology and Oceanography 46, 38-48.

Abelho, M., 2001. From litterfall to breakdown in streams: a review. The Scientific World Journal 1, 656-680.

Aitkenhead-Peterson, J. A., McDowell, W. H., Neff, J. C., Stuart, E. G. F., \& Robert, L. S., 2003. Sources, production, and regulation of allochthonous dissolved organic matter inputs to surface waters. San Diego: Academic Press.

Battin, T. J., Luyssaert, S., Kaplan, L. A., Aufdenkampe, A. K., Richter, A., Tranvik, L. J. , 2009. The boundless carbon cycle. Nature Geoscience 2, 598-600.

Benner, R., Fogel, M., Sprague, E., Hodson, R., 1987. Depletion of C in lignin and its implications for stable carbon isotope studies. Nature 329, 708-710.

Bianchi, T.S., 2007. Biogeochemistry of estuaries. Oxford University Press New York.

Bushaw-Newton, K.L., Kreeger, D.A., Doaty, S., Velinsky, D.J., 2008. Utilization of Spartina-and Phragmites-derived dissolved organic matter by bacteria and ribbed mussels (Geukensia demissa) from Delaware Bay salt marshes. Estuaries and Coasts 31, 694-703.

Bushaw-Newton, K.L., Moran, M.A., 1999. Photochemical formation of biologically available nitrogen from dissolved humic substances in coastal marine systems. Aquatic Microbial Ecology 18, 285-292.

Barlocher, F.,Gessner,M.O., Methods to study litter decomposition: a practical guide. Springer, Netherlands. 2005. 33-3

Balcarczyk, K., Jones,J.B., Jaffé,R .,Maie,N., 2009. Dissolved organic matter bioavailability and composition in streams draining catchments with discontinuous permafrost.Biogeochemistry 94, 255-270 
Belzile, C., Gibson, J. A., Vincent, W. F., 2002. Colored dissolved organic matter and dissolved organic carbon exclusion from lake ice: Implications for irradiance transmission and carbon cycling. Limnology and Oceanography 47, 1283-1293.

Brown, V. A., McDonnell, J. J., Burns, D. A., Kendall, C., 1999. The role of event water, a rapid shallow flow component, and catchment size in summer stormflow. Journal of Hydrology 217, 171-190.

Cawley, K.M., Ding, Y., Fourqurean, J., Jaffé, R., 2012. Characterising the sources and fate of dissolved organic matter in Shark Bay, Australia: a preliminary study using optical properties and stable carbon isotopes. Marine and Freshwater Research 63, 1098-1107.

Chalmers, A.G., Wiegert, R.G., Wolf, P.L., 1985. Carbon balance in a salt marsh: Interactions of diffusive export, tidal deposition and rainfall-caused erosion. Estuarine, Coastal and Shelf Science 21, 757-771.

Coble, P. G., Green, S. A., Blough, N. V., Gagosian, R. B., 1990. Characterization of dissolved organic matter in the Black Sea by fluorescence spectroscopy. Nature 348, 432435

Coble, P.G., 1996. Characterization of marine and terrestrial DOM in seawater using excitation-emission matrix spectroscopy. Marine Chemistry 51, 325-346.

Coffin, R.B., Fry, B., Peterson, B.J., Wright, R.T., 1989. Carbon isotopic compositions of estuarine bacteria. Limnology and Oceanography 34, 1305-1310.

Cory, R.M., McKnight, D.M., 2005. Fluorescence spectroscopy reveals ubiquitous presence of oxidized and reduced quinones in dissolved organic matter. Environmental Science and Technology 39, 8142-8149.

Craft, C., 2007. Freshwater input structures soil properties, vertical accretion, and nutrient accumulation of Georgia and US tidal marshes. Limnology and Oceanography 52, 1220-1230.

Cuss, C., Guéguen, C., 2012. Determination of relative molecular weights of fluorescent components in dissolved organic matter using asymmetrical flow field-flow fractionation and parallel factor analysis. Analytica Chimica Acta 733, 98-102.

Cammack, W. K., Kalff, L. J., Prairie,Y. T., Smith,E.M.,2004. Fluorescent dissolved organic matter in lakes: Relationships with heterotrophic metabolism. Limnology and. Oceanography 49, 2034-2045.

Chen, M., Jaffé, R. 2014. Photo-and bio-reactivity patterns of dissolved organic matter from biomass and soil leachates and surface waters in a subtropical wetland. Water Research 61, 181-190. 
Cloern, J. E., Canuel, E. A., Harris, D., 2002. Stable carbon and nitrogen isotope composition of aquatic and terrestrial plants of the San Francisco Bay estuarine system. Limnology and Oceanography 47, 713-729.

Dankers, N., Binsbergen, M., Zegers, K., Laane, R.,van der Loeff, M. R., 1984. Transportation of water, particulate and dissolved organic and inorganic matter between a salt marsh and the Ems-Dollard estuary, The Netherlands. Estuarine, Coastal and Shelf Science 19, 143-165.

Dai, J., Sun, M.-Y., 2007. Organic matter sources and their use by bacteria in the sediments of the Altamaha estuary during high and low discharge periods. Organic Geochemistry 38, 1-15.

Dittmar, T., 2008. The molecular level determination of black carbon in marine dissolved organic matter. Organic Geochemistry 39, 396-407.

Determann, S., Lobbes,J.M.,Reuter,R,M., J. Rullkötter.,1998. Ultraviolet fluorescence excitation and emission spectroscopy of marine algae and bacteria. Marine Chemistry 62, 137-156,

Dame, R., Alber, M., Allen, D., Mallin, M., Montague, C., Lewitus, A., ChaLmers,A.,Gardner,R.,Gilman,C., Kjerfve,B., Pickney,J., Smith, N., 2000. Estuaries of the south Atlantic coast of North America: their geographical signatures. Estuaries, 23, 793-819.

Eckert, J., Sholkovitz, E., 1976. The flocculation of iron, aluminium and humates from river water by electrolytes. Geochimica et Cosmochimica Acta 40, 847-848.

Fox, I.E., 1983. The removal of dissolved humic acid during estuarine mixing.Esutaries, Coastal and Shelf Science 16, 431-440.

France, R. L.,1995. Carbon-13 enrichment in benthic compared to planktonic algae: foodweb implications. Marine ecology progress series. Marine Ecology Progress Series 124, 307-312.

Fellman, J. B., D’Amore, D. V., Hood, E., Boone, R. D., 2008. Fluorescence characteristics and biodegradability of dissolved organic matter in forest and wetland soils from coastal temperate watersheds in southeast Alaska. Biogeochemistry 88, 169 184.

Gallagher, J.L., Reimold, R.J., Linthurst, R.A., Pfeiffer, W.J., 1980. Aerial production, mortality, and mineral accumulation-export dynamics in Spartina alterniflora and Juncus roemerianus plant stands in a Georgia salt marsh. Ecology 61, 303-312. 
Gardner, G.B., Chen, R.F., Berry, A., 2005. High-resolution measurements of chromophoric dissolved organic matter (CDOM) in the Neponset River Estuary, Boston Harbor, MA. Marine Chemistry 96, 137-154.

Gardner, W.S., Menzel, D.W., 1974. Phenolic aldehydes as indicators of terrestrially derived organic matter in the sea. Geochimica et Cosmochimica Acta 38, 813-822.

Green, N. W., Perdue, E. M., Aiken, G. R., Butler, K. D., Chen, H., Dittmar, T., Niggemann,J., Stubbins, A., 2014. An intercomparison of three methods for the largescale isolation of oceanic dissolved organic matter. Marine Chemistry 161, 14-19.

Haines, E., 1977. The origins of detritus in Georgia salt marsh estuaries. Oikos 29, 254260.

Haines, E.B., Montague, C.L., 1979. Food Sources of Estuarine Invertebrates Analyzed Using $\delta^{13} \mathrm{C}$. Ecology 60, 48-56.

Hedges, J.I., Ertel, J.R., 1982. Characterization of lignin by gas capillary chromatography of cupric oxide oxidation products. Analytical Chemistry 54, 174-178.

Hedges, J.I., Parker, P.L., 1976. Land-derived organic matter in surface sediments from the Gulf of Mexico. Geochimica et Cosmochimica Acta 40, 1019-1029.

Helms, J.R., Stubbins, A., Ritchie, J.D., Minor, E.C., Kieber, D.J., Mopper, K., 2008. Absorption spectral slopes and slope ratios as indicators of molecular weight, source, and photobleaching of chromophoric dissolved organic matter. Limnology and Oceanography 53,955 .

Helms, J. R., Stubbins, A., Perdue, E. M., Green, N. W., Chen, H., Mopper, K., 2013. Photochemical bleaching of oceanic dissolved organic matter and its effect on absorption spectral slope and fluorescence. Marine Chemistry 155, 81-91.

Higinbotham, C.B., Alber, M., Chalmers, A.G., 2004. Analysis of tidal marsh vegetation patterns in two Georgia estuaries using aerial photography and GIS. Estuaries 27, 670683.

Hopkinson Jr, C., 1985. Shallow-water benthic and pelagic metabolism. Marine Biology 87, 19-32.

Hinton, M. J., Schiff, S. L.,English, M. C., 1998. Sources and flowpaths of dissolved organic carbon during storms in two forested watersheds of the Precambrian Shield. Biogeochemistry 41, 175-197. 
Jaffé, R., Boyer, J., Lu, X., Maie, N., Yang, C., Scully, N., Mock, S., 2004. Source characterization of dissolved organic matter in a subtropical mangrove-dominated estuary by fluorescence analysis. Marine Chemistry 84, 195-210.

Jaffé, R., McKnight, D., Maie, N., Cory, R., McDowell, W., Campbell, J., 2008. Spatial and temporal variations in DOM composition in ecosystems: The importance of longterm monitoring of optical properties. Journal of Geophysical Research 113, G04032.

Jaffé R., Cawley K., and Yamashita Y., 2014. Applications of excitation emission matrix fluorescence with parallel factor analysis (EEM-PARAFAC) in assessing environmental dynamics of natural dissolved organic matter (DOM) in aquatic environments: A review. Advances in the Physicochemical Characterization of Organic Matter, ACS Series. 2773.

Kilic, S.G., Aral, M.M., 2009. A fugacity based continuous and dynamic fate and transport model for river networks and its application to Altamaha River. Science of the Total Environment 407, 3855-3866.

Kirby, C.J., Gosselink, J.G., 1976. Primary production in a Louisiana Gulf Coast Spartina alterniflora marsh. Ecology 57, 1052-1059.

Katz, R. W., Parlange, M. B., Tebaldi, C., 2003. Stochastic modeling of the effects of large-scale circulation on daily weather in the southeastern US. Climatic Change 60, 189216.

Lakowicz, J. R., Fu, Y., 2009. Modification of single molecule fluorescence near metallic nanostructures. Laser and Photonics Reviews 3, 221-232.

Mantoura, R., Woodward, E., 1983. Conservative behaviour of riverine dissolved organic carbon in the Severn Estuary: chemical and geochemical implications. Geochimica et Cosmochimica Acta 47, 1293-1309.

Meyer, J.L., Wallace, J.B., Eggert, S.L., 1998. Leaf litter as a source of dissolved organic carbon in streams. Ecosystems 1, 240-249.

Moore, R., Burton, J., Williams, P., Young, M., 1979. The behaviour of dissolved organic material, iron and manganese in estuarine mixing. Geochimica et Cosmochimica Acta 43, 919-926.

Moran, M.A., Hodson, R.E., 1989. Formation and bacterial utilization of dissolved organic carbon derived from detrital lignocellulose. Limnology and Oceanography 34 , 1034-1047. 
Moran, M.A., Pomeroy, L.R., Sheppard, E.S., Atkinson, L.P., Hodson, R.E., 1991. Distribution of terrestrially derived dissolved organic matter on the southeastern US continental shelf. Limnology and Oceanography 36, 1134-1149.

Malcolm,R.I.1990. The uniqueness of humic substances in each of soil, stream and marine environmentas. Analytica Chimica Acta 232, 19-30.

McKnight, D. M., Boyer, E. W., Westerhoff, P. K., Doran, P. T., Kulbe, T., Andersen, D. T., 2001. Spectrofluorometric characterization of dissolved organic matter for indication of precursor organic material and aromaticity. Limnology and Oceanography 46, 38-48.

Maie, N., Boyer,J.N., Yang,C.,Jaffé,R., 2006. Spatial, geomorphological, seasonal variability of CDOM in estuaries of the Florida Coastal Everglades. Hydrobiologia 569, $135-150$,

Maie, N., Sekiguchi, S., Watanabe, A., Tsutsuki, K., Yamashita, Y., Melling, L., Cawley, K., Shima,E., Jaffé, R., 2014. Dissolved organic matter dynamics in the oligo/mesohaline zone of wetland-influenced coastal rivers. Journal of Sea Research 91, 58-69

Nixon, S. W., 1980. Between coastal marshes and coastal waters-a review of twenty years of speculation and research on the role of salt marshes in estuarine productivity and water chemistry, 437-525. Springer US.

Odum, W.E., 1988. Comparative ecology of tidal freshwater and salt marshes. Annual Review of Ecology and Systematics 19, 147-176.

Opsahl, S., Benner, R., 1997. Distribution and cycling of terrigenous dissolved organic matter in the ocean. Nature 386, $480-48$.

Osburn, C.L., Stedmon, C.A., 2011. Linking the chemical and optical properties of dissolved organic matter in the Baltic-North Sea transition zone to differentiate three allochthonous inputs. Marine chemistry 126, 281-294.

Olefeldt, D., Turetsky, M. R., Blodau, C., 2013. Altered composition and microbial versus UV-mediated degradation of dissolved organic matter in boreal soils following wildfire. Ecosystems 16, 1396-1412.

Peterson, B. J., Howarth, R. W.,Garritt, R. H.,1986. Sulfur and carbon isotopes as tracers of salt-marsh organic matter flow. Ecology, 865-874.

Peterson, B. J., Fry, B., 1987. Stable isotopes in ecosystem studies. Annual review of ecology and systematics 18, 293-320. 
Peterson, B. J., Howarth, R. W., 1987. Sulfur, carbon, and nitrogen isotopes used to trace organic matter flow in the salt-marsh estuaries of Sapelo Island, Georgia. Limnology and Oceanography 32, 1195-1213.

Peterson, B. J., Howarth, R. W., 1987. Sulfur, carbon, and nitrogen isotopes used to trace organic matter flow in the salt-marsh estuaries of Sapelo Island, Georgia. Limnology and oceanography 32, 1195-1213.

Peterson, B., Fry, B., Hullar, M., Saupe, S., Wright, R., 1994. The distribution and stable carbon isotopic composition of dissolved organic carbon in estuaries. Estuaries 17, 111121.

Pomeroy, L.R., and R.G.Wiegert.1981. The Ecology of a Salt Marsh. Springer Verlag, New York.

Rochelle-Newall, E., Fisher, T., 2002. Production of chromophoric dissolved organic matter fluorescence in marine and estuarine environments: an investigation into the role of phytoplankton. Marine Chemistry 77, 7-21.

Saraceno, J.F., Pellerin, B.A., Downing, B.D., Boss, E., Bachand, P.A., Bergamaschi, B.A., 2009. High frequency in situ optical measurements during a storm event: Assessing relationships between dissolved organic matter, sediment concentrations, and hydrologic processes. Journal of Geophysical Research: Biogeosciences 114, G00F09

Scully, N.M., Maie, N., Dailey, S.K., Boyer, J.N., Jones, R.D., Jaffé, R., 2004. Early diagenesis of plant-derived dissolved organic matter along a wetland, mangrove, estuary ecotone. Limnology and Oceanography 49, 1667-1678.

Sherr, E.B., 1982. Carbon isotope composition of organic seston and sediments in a Georgia salt marsh estuary. Geochimica et Cosmochimica Acta 46, 1227-1232.

Shi, W., Sun, M.-Y., Molina, M., Hodson, R.E., 2001. Variability in the distribution of lipid biomarkers and their molecular isotopic composition in Altamaha estuarine sediments: implications for the relative contribution of organic matter from various sources. Organic Geochemistry 32, 453-467.

Sholkovitz, E., 1976. Flocculation of dissolved organic and inorganic matter during the mixing of river water and seawater. Geochimica et Cosmochimica Acta 40, 831-845.

Singh, S., D'Sa, E.J., Swenson, E.M., 2010. Chromophoric dissolved organic matter (CDOM) variability in Barataria Basin using excitation-emission matrix (EEM) fluorescence and parallel factor analysis (PARAFAC). Science of the Total Environment 408, 3211-3222. 
Spencer, R.G., Ahad, J.M., Baker, A., Cowie, G.L., Ganeshram, R., Upstill-Goddard, R.C., Uher, G., 2007. The estuarine mixing behaviour of peatland derived dissolved organic carbon and its relationship to chromophoric dissolved organic matter in two North Sea estuaries (UK). Estuarine, Coastal and Shelf Science 74, 131-144.

Stedmon, C.A., Bro, R., 2008. Characterizing dissolved organic matter fluorescence with parallel factor analysis: a tutorial. Limnology and Oceanography. Methods 6, 572-579.

Stedmon, C.A., Markager, S., 2005. Resolving the variability in dissolved organic matter fluorescence in a temperate estuary and its catchment using PARAFAC analysis. Limnology and Oceanography 50, 686-697.

Stedmon, C.A., Markager, S., Bro, R., 2003. Tracing dissolved organic matter in aquatic environments using a new approach to fluorescence spectroscopy. Marine Chemistry 82, 239-254.

Stedmon, C. A., Markager, S., 2003. Behaviour of the optical properties of coloured dissolved organic matter under conservative mixing. Estuarine, Coastal and Shelf Science 57, 973-979.

Stribling, J. M., Cornwell, J. C., 1997. Identification of important primary producers in a Chesapeake Bay tidal creek system using stable isotopes of carbon and sulfur. Estuaries, 20, 77-85.

Sheldon, J. E., Burd, A. B., 2014. Alternating Effects of Climate Drivers on Altamaha River Discharge to Coastal Georgia, USA. Estuaries and Coasts 37, 772-788.

Thomas, J. D., 1997. The role of dissolved organic matter, particularly free amino acids and humic substances, in freshwater ecosystems. Freshwater Biology 38, 1-36.

Turner, R.E., 1978. Community plankton respiration in a salt marsh estuary and the importance of macrophytic leachates. Limnology and Oceanography 23, 442-451.

Turner, R.E., 1993. Carbon, nitrogen, and phosphorus leaching rates from Spartina alterniflora salt marshes. Marine Ecology Progress Series 92, 135-135.

Tzortziou, M., Neale, P.J., Osburn, C.L., Megonigal, J.P., Maie, N., Jaffé, R., 2008. Tidal marshes as a source of optically and chemically distinctive colored dissolved organic matter in the Chesapeake Bay. Limnology and Oceanography 53, 148.

Teal, J.M., 1962.Energy flow in the salt marsh ecosystem of Georgia. Ecology 43,614624 
Townsend-Small, A., McClelland, J. W., Holmes, R. M., Peterson, B. J., 2011. Seasonal and hydrologic drivers of dissolved organic matter and nutrients in the upper Kuparuk River, Alaskan Arctic. Biogeochemistry 103, 109-124.

Wang, X.-C., Litz, L., Chen, R.F., Huang, W., Feng, P., Altabet, M.A., 2007. Release of dissolved organic matter during oxic and anoxic decomposition of salt marsh cordgrass. Marine Chemistry 105, 309-321.

Vogel, R. M., Stedinger, J. R., Hooper, R. P., 2003. Discharge indices for water quality loads. Water Resources Research 39,1273-1281.

Vidon, P., Wagner, L. E.,Soyeux, E., 2008. Changes in the character of DOC in streams during storms in two Midwestern watersheds with contrasting land uses. Biogeochemistry 88, 257-270.

Wetzel, R. G., 1984. Detrital dissolved and particulate organic carbon functions in aquatic ecosystems. Bulletin of Marine Science 35, 503-509.

Więski, K., Guo, H., Craft, C.B., Pennings, S.C., 2010. Ecosystem functions of tidal fresh, brackish, and salt marshes on the Georgia Coast. Estuaries and Coasts 33, 161-169.

Weston, N. B., Vile, M. A., Neubauer, S. C., Velinsky, D. J., 2011. Accelerated microbial organic matter mineralization following salt-water intrusion into tidal freshwater marsh soils. Biogeochemistry 102, 135-151.

Wilson,H. F., Xenopoulos, M. A., 2008. Ecosystem and seasonal control of stream dissolved organic carbon along a gradient of land use. Ecosystems 11, 555-568.

Williams, C. J., Yamashita, Y., Wilson, H. F., Jaffé, R., Xenopoulos, M. A., 2010. Unraveling the role of land use and microbial activity in shaping dissolved organic matter characteristics in stream ecosystems. Limnology and Oceanography 55, 1159-1171.

Wheatcroft, R. A., Goni, M. A., Hatten, J. A., Pasternack, G. B., Warrick, J. A.,2010. The role of effective discharge in the ocean delivery of particulate organic carbon by small, mountainous river systems. Limnology and Oceanography 55, 161-171

Witte, W. G., Whitlock, C. H., Harriss, R. C., Usry, J. W., Poole, L. R., Houghton, W. M., Morris,W.D., Gurganus, E. A.,1982. Influence of dissolved organic materials on turbid water optical properties and remote-sensing reflectance. Journal of Geophysical Research: Oceans 87, 441-446.

Wang, X., Chen, R. F., Cable, J. E., Cherrier, J. 2014. Leaching and microbial degradation of dissolved organic matter from salt marsh plants and seagrasses. Aquatic Sciences 76, 595-609. 
Yamashita, Y., Tanoue, E., 2003. Chemical characterization of protein-like fluorophores in DOM in relation to aromatic amino acids. Marine Chemistry 82, 255-271.

Yamashita, Y., Jaffé, R., Male, N., Tanoue, E., 2008. Assessing the dynamics of dissolved organic matter (DOM) in coastal environments by excitation emission matrix fluorescence and parallel factor analysis (EEM-PARAFAC). Limnology and Oceanography 53, 1900-1908.

Yamashita, Y., Scinto, L.J., Maie, N., Jaffé, R., 2010. Dissolved organic matter characteristics across a subtropical wetland's landscape: application of optical properties in the assessment of environmental dynamics. Ecosystems 13, 1006-1019.

Yamashita, Y., Panton, A., Mahaffey, C., Jaffé, R., 2011. Assessing the spatial and temporal variability of dissolved organic matter in Liverpool Bay using excitationemission matrix fluorescence and parallel factor analysis. Ocean Dynamics 61, 569-579.

Yamashita, Y., Boyer, J. N., Jaffe, R., 2013. Evaluating the distribution of terrestrial dissolved organic matter in a complex coastal ecosystem using fluorescence spectroscopy. Continental Shelf Research 66, 136-144. 


\section{CHAPTER IV}

ORGANIC MATTER DYNAMICS IN A MANGROVE DOMINATED ESTUARY: COMPARISONS BETWEEN DISSOLVED AND PARTICULATE ORGANIC MATTER 


\subsection{Abstract}

Excitation emission matrix fluorescence with parallel factor analysis (EEMPARAFAC) and stable carbon isotopes were applied to comparatively study the composition and assess sources of particulate organic matter (POM) and dissolved organic matter (DOM) in a mangrove influenced subtropical estuarine ecosystem. Fluorescence measurements showed distinctly different optical properties between POM base extracts and DOM in the same water samples. While both compositional similarities and dissimilarities between POM and DOM pools were observed, POM base extract EEM-PARAFAC distributions showed that the POM fluorescence signal is less terrestrially influenced (lower abundance of terrestrial humic-like components) and enriched in protein-like components (35\% and 31\% during dry and wet seasons respectively). While DOM showed a non-conservative mixing, the POM increased linearly along the salinity gradient $\left(r^{2}=0.94\right.$ and 0.91 , wet and dry season, respectively), confirming that the DOM is primarily derived from the freshwater end-member with some mangrove contributions, while the POM sources are primarily mangrove-derived in the upper estuary with increasing marine, most likely seagrass detritus-derived sources seawards. In agreement, POC showed more depleted $\delta^{13} \mathrm{C}$ values in the mangrove influenced zone during the wet and dry seasons (-27.6\%o and $-31.4 \%$ respectively) but more enriched values in the lower estuary $(-19.7 \%$ and $-23.2 \%)$ during the wet and dry season respectively. Estimated POM flux values (ranging from $8.0 \times 10^{10}$ to $1.8 \times 10^{12} \mathrm{mg}$ $\left.\mathrm{d}^{-1}\right)$ were close to those of DOC $\left(9.5 \times 10^{9}\right.$ to $\left.2.5 \times 10^{10} \mathrm{mg} \mathrm{C} \mathrm{d}^{-1}\right)$. The decoupling of DOM and POM composition clearly suggests different sources for these OM pools in South 
Florida estuaries. Based on this study the fringe mangrove swamps in the Everglades may be a more significant source of POC than of DOC to the coastal zone, while exchange with seagrass-derived POM in the lower estuary may be a critical source of less refractory POM to food webs.

\subsection{Introduction}

Particulate organic matter (POM) is an important component in carbon cycling and controls a variety of biogeochemical processes. It is a complex assemblage of detritus, extracellular polymers and cellular debris (Droppo, 2001). Estuaries can serve as both sources and sinks of organic material (Bianchi and Bauer, 2011), and multiple nonpoint sources can contribute to the POM pool in estuaries, including river discharges, export from adjacent wetlands and autochthonous primary productivity (Maksymowska et al., 2000; Goni et al., 2005; Bristow et al., 2013). Marine-derived POM can be transported into estuaries through tidal exchange, and while it is commonly dominated by planktonic sources (Brym et al., 2014), sediment resuspension during tidal exchange can also be important (Shimeta et al., 2003). Fringe mangrove forests compose about $60-75 \%$ of the watersheds of tropical estuaries (Clough, 1998) and export large amounts of organic substances (Alongi, 1990, Alongi et al., 1989; Bouillon et al., 2008) to the coastal ocean. Tropical and subtropical fringe mangrove ecosystems are considered a significant source of dissolved organic matter (DOM) to the coastal ocean (Dittmar et al., 2001; Jaffé et al., 2004; Cawley et al., 2014). However, there is no general consensus on the magnitude of mangrove-derived vs. freshwater or marine end-member contributions to the POM pool in such environments (Dittmar et al., 2001). Apart of the mixing of OM 
sources (mangrove, terrestrial and marine; Dittmar et al., 2001), living vs. nonliving sources of POM may vary with vegetation type, estuarine geomorphology, and hydrology, among others. In addition, POC dynamics can be influenced by diverse factors such as water discharge (Chao, 1988; Czitrom, 1986), turbulence (West and Sangodoyin, 1991) and tidal mixing (Hill et al., 1993). OM from different sources is not only transported by coastal rivers through estuaries but it also undergoes transformations before reaching the ocean (Markager et al., 2011; Bristow et al., 2013).

Therefore, it can be a complex task to assess sources and composition of POM in estuaries. Such is the case of the fringe mangrove estuary in Everglades National Park, Florida. The Harney and Shark Rivers are major components of the Shark River Slough watershed, the main drainage system for the SW Everglades ecosystem. Freshwater marsh vegetation (Cladium, Eleocharis, and periphyton) dominate the upstream region while mangroves (mainly the red mangrove, Rhizophora mangle) line the channel and tidal creeks of the estuarine zone. Waters draining the freshwater marsh flows through fringe mangrove swamps into the coastal zone where seagrass communities are common (Figure 4.1). Along with the DOM enriched, freshwater marsh, waters, the estuarine mangrove fringe contributes up to an additional 20\% to the DOM pool (Cawley et al., 2014).

In contrast, the freshwater marshes of the Everglades are depleted in suspended POM as this matter is mainly in the form of flocculent materials (floc; Neto et al., 2006), which although mobile (Larsen et al., 2009) is believed to only minimally contribute to the POM pool in the estuarine zone (He et al., 2014). With respect to the diversity of 
mangrove functions in OM cycling, mangrove-derived contributions to POM can be geomorphologically variable. For example, mangrove-derived DOM and POM were reported to be in similar proportions to the coastal zone in Brazilian coastal waters (Dittmar et al., 2001). However, for two different mangrove-fringed subtropical estuaries in Florida, Rookery Bay and the Shark River, different quantification was observed on the mangrove exported POM vs. DOM. While He et al., (2014) and Cawley et al. (2014) reported similar fluxes of mangrove-derived POM and DOM (same order of magnitude) in the Shark River estuary, for Rookery Bay, Twilley (1985) suggested a continuous mangrove-derived export of OM dominated by the POM pool, while high DOM export was only observed during high tide when mangrove outwelling peaked. Clearly, OM dynamics in mangrove ecosystems are dependent on a variety of ecological and hydrological drivers, and as such can be quite variable, where DOM and POM can be either coupled or decoupled. Considering the importance of estuarine carbon export in the assessment of carbon cycling in the ocean, a better understanding of the relationship between POM and DOM justifies further comparative studies on their sources and transport in mangrove ecosystem.

Generally, POM tends to be enriched in labile components such as amino acids and lipids (Wakeham et al., 1984). Compared with POM, DOM showed less reactivity and seems more diagenetically altered, being nitrogen-poor, more oxidized, and depleted in aliphatic structures (Raymond and Bauer, 2001; Tremblay and Gagne, 2009). However, in mangrove-influenced estuaries POM has been suggested to be more reworked and recalcitrant (Dittmar et al., 2001). While POM can absorb light at 
wavelengths similar to DOM (Kirk, 1980), the photo-dissolution of POM to DOM (Mayer et al., 2006; Shank et al., 2010), including mangrove derived soil organic matter (Pisani et al., 2011), has been suggested to be a potentially significant source of DOM in estuaries (Dittmar et al., 2006; Cawley et al., 2014). Thus, photo-dissolution may represent a direct link between estuarine POM and DOM. Considering that POM might share similar fluorescence characteristics with DOM, for ease of comparison between these two organic matter pools, excitation emission matrix fluorescence with parallel factor analysis (EEM-PARAFAC) has been used to characterize base extracts of soil OM (Santin et al., 2009) and comparatively between POM and DOM in an estuarine setting (Osburn et al., 2012; Brym et al., 2014).

In addition to optical measurements, stable carbon isotopes $\left(\delta^{13} \mathrm{C}\right)$ have commonly been used to distinguish allochthonous versus autochthonous OC inputs to estuaries (Peterson and Fry, 1987; Goñi et al., 1998; Bianchi et al., 2002). While the isotopic composition of POM tends to resemble that of the riparian vegetation (Hedges et al., 1994), limitations in using $\delta^{13} \mathrm{C}$ to distinguish between mangrove and other terrestrialderived POM have been pointed out (Dittmar et al., 2001). However, $\delta^{13} \mathrm{C}$ can clearly differentiate between seagrass-derived and mangrove-and/or terrestrially-derived organic matter (Fourqurean et al., 2005; Fry and Smith, 2002) due to the C4-like composition of the former. Thus, we hypothesize that applying both, optical properties and stable carbon isotope measurements to assess sources of DOM and POM in estuaries may be an ideal combination for subtropical ecosystems where both mangroves and seagrasses are 
significant sources of detrital carbon such as the estuaries of Everglades National Park, Florida.

\subsection{Samples and Methods}

Surface water samples $(120 \mathrm{ml})$ along both Harney River and Shark River salinity transects were collected during the wet seasons (November 2012 and 2013) and dry seasons (March 2013 and 2014) and stored on ice until transferred to the laboratory (see Table 4.1). The POM was obtained by filtration $(120 \mathrm{ml})$ through $0.7 \mu \mathrm{m}$ pre-combusted glass fiber filters (25 mm, Whatman GF/F). POM samples were collected on separated filters for optical properties and stable carbon isotopic analysis. Additional triplicate POM samples were collected in 2 L polycarbonate bottles and later filtered through precombusted $142 \mathrm{~mm}$ GF/F filters $(0.7 \mu \mathrm{m}$ nominal pore size $)$ for determination of POM concentration through the weight of difference before and after combustion (Rumpel et al., 2001). The filtrate was kept in dark at $4{ }^{\circ} \mathrm{C}$ for the DOM isotope analysis. Separately, $60 \mathrm{ml}$ surface water samples were collected at the same sites in pre-cleaned, brown polyethylene bottles (Nalgene), syringe-filtered in the field through GF/F filters, and stored on ice until transferred to the laboratory. Filtered samples were stored in a refrigerator at $4{ }^{\circ} \mathrm{C}$ until DOM measurement and optical properties determinations. The resulting filters were stored in $1.5 \mathrm{~mL}$ of $90 \%$ acetone/water in $1.8 \mathrm{~mL}$ plastic centrifuge tubes for chlorophyll a (Chl-a) analysis (Boyer et al., 1997). Salinity, temperature,

turbidity (NTU), dissolved oxygen $\left(\mathrm{mg} \mathrm{L}^{-1}\right)$ and $\mathrm{pH}$ were also recorded in the field using YSI 600XL sonde probe. Real-time river discharge data were obtained from the USGS (http://waterdata.usgs.gov/fl. Harney River \#25255108105900). 
For optical properties determinations, the POM collected on the filters was extracted using $10 \mathrm{ml}$ of $0.1 \mathrm{~N} \mathrm{NaOH}$ for $24 \mathrm{~h}$ in the dark at $4{ }^{\circ} \mathrm{C}$ and then neutralized with $\mathrm{HCl}$ to a pH between 6 and 8 (Osburn et al., 2012). The neutralized POM base-extract was filtered through $0.45 \mu \mathrm{m} \mathrm{GF} / \mathrm{F}$ filter prior to analysis. EEM spectra for both POM and DOM were measured using a Horiba Jovin Yvon SPEX Fluoromax-3 fluorometer. EEMs were collected over an excitation wavelength range of $240-455 \mathrm{~nm}$ with an increment of $5 \mathrm{~nm}$ and an emission wavelength range of 250-705 nm with an increment of $2 \mathrm{~nm}$. The fluorescence signal was acquired in signal over reference mode (S/R). The absorbance at $254 \mathrm{~nm}$ was determined using a Varian Cary 50 bio spectrophotometer with a $1 \mathrm{~cm}$ quartz cuvette scanning from $200 \mathrm{~nm}$ to $800 \mathrm{~nm}$. EEMs were corrected for instrument bias, inner-filter effects (Ohno, 2002), blank subtracted and normalized to Raman units and reported in quinine sulfate units (QSU) using MATLAB 7.0. EEMs of the DOM and the POM base extract were fit to the existing eight-component PARAFAC model for Everglades DOM described in Chen et al. (2010) and Yamashita et al. (2010). Residuals (residual signal $\%>3 \times$ noise $\%$ ) after model fitting was calculated using the average EEM-PARAFAC residue values for the POM base extract samples which represents the average normal noise)

For POC stable carbon isotopic analysis $\left(\delta^{13} \mathrm{C}\right)$, dried filter samples were treated with $1 \mathrm{~N} \mathrm{HCl}$ to remove carbonates, washed with deionized water, and oven dried $\left(70^{\circ} \mathrm{C}\right)$. The $\delta^{13} \mathrm{C}$ analysis was conducted using the standard elemental analyzer-isotope ratio mass spectrometry (EA-IRMS) method on a Finnigan MAT Delta C IRMS. Sample reproducibility for bulk carbon analysis based on glycine standard was $\pm 0.05 \%$. 
DOC for stable isotope analysis was collected using solid phase extraction (SPE). Variant Bond Elut PPL (1g) cartridges were conditioned using methanol (20 ml, HPLC grade) before applying samples. Approximately $2 \mathrm{~L}$ samples were extracted by gravity after being acidified to $\mathrm{pH}=2$ using concentrated $\mathrm{HCl}$. Salts were eliminated by rinsing with $0.01 \mathrm{~N} \mathrm{HCl}$ immediately after adsorption. Cartridges were then dried under putrefied $\mathrm{N}_{2}$ gas stream and eluted with $20 \mathrm{~mL} \mathrm{MeOH}$. The eluates were stored in $\mathrm{MeOH}$ at $-18^{\circ} \mathrm{C}$. The extraction efficiency for DOC by this SPE technique was reported to be $62 \%$ (Dittmar, 2008). The extract was pipetted into a tin capsule and dried at a temperature less than $40{ }^{\circ} \mathrm{C}$ until reaching constant weight of $\sim 100 \mathrm{ug}$, which met the detection limit for the instrumental isotope analysis.

Stable ${ }^{13} \mathrm{C}$ isotope analysis was performed at the FIU SERC Stable Isotope Laboratory using standard elemental analyzer isotope ratio mass spectrometer (EAIRMS) procedures (Anderson and Fourqurean, 2003). Samples were combusted in EA, forming $\mathrm{CO}_{2}$ and then measured on a Finnigan MAT Dalta C IRMS in a continuous flow mode. Isotope results were reported as isotope ratio in the standard delta notation (\%o): $(\%)=\left[\left(\mathrm{R}_{\text {sample }} / \mathrm{R}_{\text {standard }}-1\right] \times 1000\right.$. International standard for carbon is Vienna PeeDee belemnite (V-PDB). Analytical reproducibility of this study based on internal standard is $\pm 0.05 \%$.

Statistical analysis, including principal component analysis (PCA), Pearson correlation, and independent t-test were conducted using SPSS 17.0. Box-and-Whisker Plots were graphed using SigmaPlot 8.0. Relative abundances of the PARAFAC components for each sample were used as loading variables for PCA. Two-tailed independent t-test was used to determine the significant difference of the relative 
abundance of PARAFAC components between POM and DOM and POM concentration between different sampling seasons.

The OM flux was calculated based on the constituent flux estimation model published by USGS (http://toxics.usgs.gov/pubs/of-2007-1080/methods.html):

$$
\varnothing=\int C(t) Q(t) d t
$$

Mass flux (Ø) of POC and DOC, is defined as the product of the constituent concentration $(C)$ and discharge $(Q)$ integrated over time $(t)$. Considering that we do not have a continuous record of OM concentration, we used the concentration measured during each sampling event, taken closest to the station where water discharge data were available. $\mathrm{Q}$ is the river discharge data calculated by summing up the real-time discharge measurement during the corresponding sampling event of the day.

To calculate the percentage of mangrove-derived DOC, measured data points (DOC concentration vs. salinity) were interpolated to 0.1 salinity increments and integrated by a left sum method using Matlab 7.8.0 (Cawley et al., 2014). The percentage value was the difference between the area under the conservative mixing line and the area under the measured data divided by the area of the measured data and multiplied by 100 (presented in Table 4.1). To calculate the percentage of mangrove-derived POC, $\delta{ }^{13} \mathrm{C}$ was used in a two end-member mass balance equation:

$\delta_{\mathrm{m}}=\mathrm{f}_{\mathrm{a}} \delta_{\mathrm{a}}+\mathrm{f}_{\mathrm{b}} \delta_{\mathrm{b}}$ $1=f_{a}+f_{b}$ where $\mathrm{f}$ is the fraction of end-member contributions, $\delta_{\mathrm{a}}$ and $\delta_{\mathrm{b}}$ are the $\delta^{13} \mathrm{C}$ value of each 
individual source, and $\delta_{\mathrm{m}}$ is the $\delta^{13} \mathrm{C}$ value of the actual POM composite in each sample. The humification index (HIX) has been proposed to determine the extent of humification by quantifying the extent of shifting of the emission spectra toward longer wavelengths with increasing humification (Ohno, 2002). The HIX value was calculated as:

$\mathrm{HIX}=\sum I_{435-480} /\left(\sum_{300-345}+\sum_{435-480}\right)$

Where I is the fluorescence intensity at each emission wavelength at an excitation wavelength of $254 \mathrm{~nm}$. In addition to HIX, spectral slope $\left(\mathrm{S} \mathrm{nm}^{-1}\right)$ has been derived from CDOM UV-vis absorption spectra by fitting the absorption data into the equation:

$\mathrm{a}_{\lambda}=\mathrm{a}_{\lambda \mathrm{ref}} \mathrm{e}^{-\mathrm{S}(\lambda-\lambda \mathrm{ref})}$

where $\mathrm{a}=$ absorption coefficient $\left(\mathrm{m}^{-1}\right), \lambda=$ wavelength $(\mathrm{nm})$ and $\lambda_{\text {ref }}=$ reference wavelength $(\mathrm{nm})$. The slope ratio $\left(\mathrm{S}_{\mathrm{R}}\right)$ is ratio between $\mathrm{S}_{275-295}$ over $\mathrm{S}_{350-400 \text {. The slopes }}$ of these two regions (275-295nm and 350-400) are visibly distinct and a proxy for DOM molecular weight (Helms et al., 2008). 

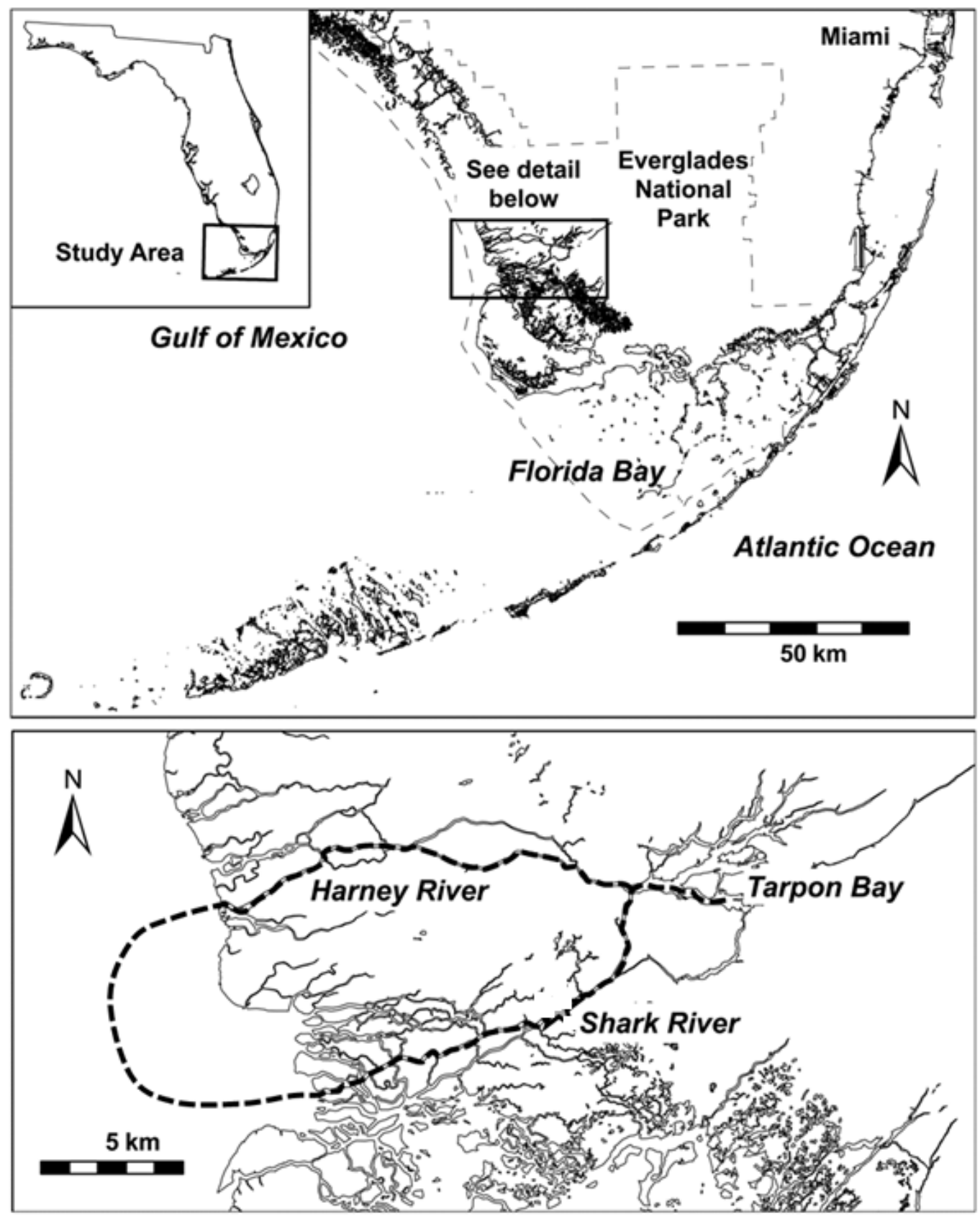

Figure 4.1 Map of Shark and Harney River transects in the Everglades. South Florida. The dotted line in the bottom panel represents the approximate path taken for the salinity transects (from Cawley et al., 2014). 


\subsection{Results and Discussion}

\subsubsection{Measurements of bulk parameters}

The hydrological pulse in the Everglades ecosystem is relatively steady, regulated by annual periodicity of wet-dry cycles. High-flow periods (wet season) in the Everglades commonly span from June to November, while the low-flow period (dry season) occurs from December to May. During our sampling events, turbidity did not show any significant difference across the seasons $(\mathrm{p}>0.05)$. Similar patterns have been reported for many estuaries where the seasonal variation of suspended particles is controlled by river discharge, tidal force, and light availability (Bianchi and Bauer, 2001). POM and suspended particulate matter are often highly correlated in estuaries (Bianchi et al., 1997). Here, average POM concentrations throughout the Harney River estuary did not show significant seasonal differences $(\mathrm{p}>0.05$, independent t-test, twotailed; 44.8 and $49.9 \mathrm{mg} / \mathrm{L}$, Nov. 2012 and Mar. 2013; 36.4 and $24.8 \mathrm{mg} / \mathrm{L}$, Nov. 2013 and Mar. 2014). Similar results have been reported by Canuel (2001), where POM concentrations in San Francisco Bay estuary did not change significantly as a function of seasons. During the dry sampling period (March 2013), the incoming tide had an impact on the POM concentration, resulting in a slightly higher POM values observed in the river mouth $(95.81 \pm 15.2 \mathrm{mg} / \mathrm{L})$ compared to the wet season (November 2012) $(85.67 \pm 2.8$ $\mathrm{mg} / \mathrm{L})$. Similarly, there was no significant difference observed in either POM concentration or turbidity between wet season (Nov. 2013; 36.4 $\pm 4.9 \mathrm{mg} / \mathrm{L}$ ) and dry season (Mar. 2014; 24.8 $\pm 3.0 \mathrm{mg} / \mathrm{L}$ ). Overall, POM concentrations did not show much variance between wet and dry seasons within the study area. 
To compare the distribution of DOC and POC concentration along the salinity gradient, $[\mathrm{POM}]$ was converted to $[\mathrm{POC}]$ by a factor of $58 \%$, which a widely accepted $\%$ OC value in soil OM (Howard, 1965). It is important to note that this conversion factor represents only a rough approximation for POM to POC, and thus POC data represent an estimation only. POC concentration and turbidity increased linearly with salinity along the estuary, showing significant conservative mixing for all seasons (Figure 4.2 and Table 4.1) and suggesting a dominant source from the lower estuary for both parameters. Similar linear distributions for POC concentration were observed along the adjacent Shark River estuary during previous sampling periods in 2010 and 2011 ( $<<0.01$, $\mathrm{R}^{2}=0.83$ for March 2011; $\mathrm{R}^{2}=0.84$ for November 2010; data not shown) and consistently in this study ( $\mathrm{R}^{2}=0.98$ and $\mathrm{R}^{2}=0.89$, November 2013 and March 2014, respectively). The increase in POC along these estuaries resembles the "upside-down" estuarine mixing pattern for phosphorus concentration in Everglades (Childers et al., 2006), indicative of the marine and mangrove derived $\mathrm{OM}$ as the major sources. This distribution pattern is very different from other estuarine ecosystems (e.g. Delaware Bay estuary), where phytoplankton biomass is the major source of POM showing a decreasing pattern along the salinity gradient with a significant increase at the lower estuary (Harvey and Mannino, 2001). Such POM distribution patterns in estuaries are often driven by plankton primary productivity (Saliot et al., 2002; Brym et al., 2014). In order to justify whether phytoplankton biomass is an important contributor to POM in the Harney and Shark river estuary, Chla data was used to assess the source strengths of phytoplankton vs. higher plant-derived detritus (Cifuentes et al., 1996). The ratio POM to Chla $\left(\mathrm{mg} \mathrm{L}^{-1} / \mu \mathrm{g} \mathrm{L}^{-1}\right)$ is an indicator used to distinguish POM origins between detritus and living algae (Parsons et 
al., 1984; Cifuentes et al., 1996). This ratio was found to be generally quite high (775318928) along the Harney and Shark River transects during all sampling seasons (Table 4.1). Parsons et al., (1984) suggest that plant detritus is a major contributor to POM when POM : Chla $>200$.

Compared with POM, and in agreement with prior reports (Cawley et al., 2014), the DOC concentration showed a very different distribution to that of POM along the Harney and Shark salinity transects in that it generally decreased with increasing salinity (Fig.4.2 and Table 4.2). DOC showed highest concentrations at the freshwater sites for both seasons (Dry: 12.4 and $13.7 \mathrm{mg} \mathrm{CL}^{-1}, 2013$ and 2014, respectively; Wet: 13.8 and 12.6 mg C L ${ }^{-1}, 2012$ and 2013, respectively) and non-conservatively decreased along the salinity gradient with lowest concentration at the lower estuary (Dry: 3.54 and $6.3 \mathrm{mg} \mathrm{C}$ $\mathrm{L}^{-1} 2013$ and 2014, respectively; Wet: 5.9 and $4.7 \mathrm{mg} \mathrm{C} \mathrm{L}^{-1} 2012$ and 2013, respectively). According to Cawley et al. (2014), the mangrove ecotone contributed at most $c a .10-20 \%$ of the DOC load to the river. In agreement, with our study period, mangrove inputs were estimated to account for about 4-12\% of DOC (Table 4.1). In contrast, mangrove export is the dominant source to the POM pool, with $c a .>90 \%$ mangrove derived contributions (Table 4.1). Unlike DOC, freshwater marsh biomass does not seem to significantly contribute to the POC pool within the estuarine zone (He et al., 2014). Thus, the difference in the distribution patterns between POC and DOC suggest at least a partial decoupling between the two parameters, where DOC seems mainly derived from the Everglades freshwater marsh end-member, while the POC is primarily derived from a combination between mangrove-derived detritus and marine end-member contributions. 
While the POM : Chla data suggest that planktonic sources may be a minor contribution to the estuarine POM pool, alternative sources such as seagrass-derived marine detritus could explain the observed patterns. Alternatively, the observed mixing pattern could be driven by the re-suspension of accumulated mangrove detritus in the lower estuary and the near shore zone. 

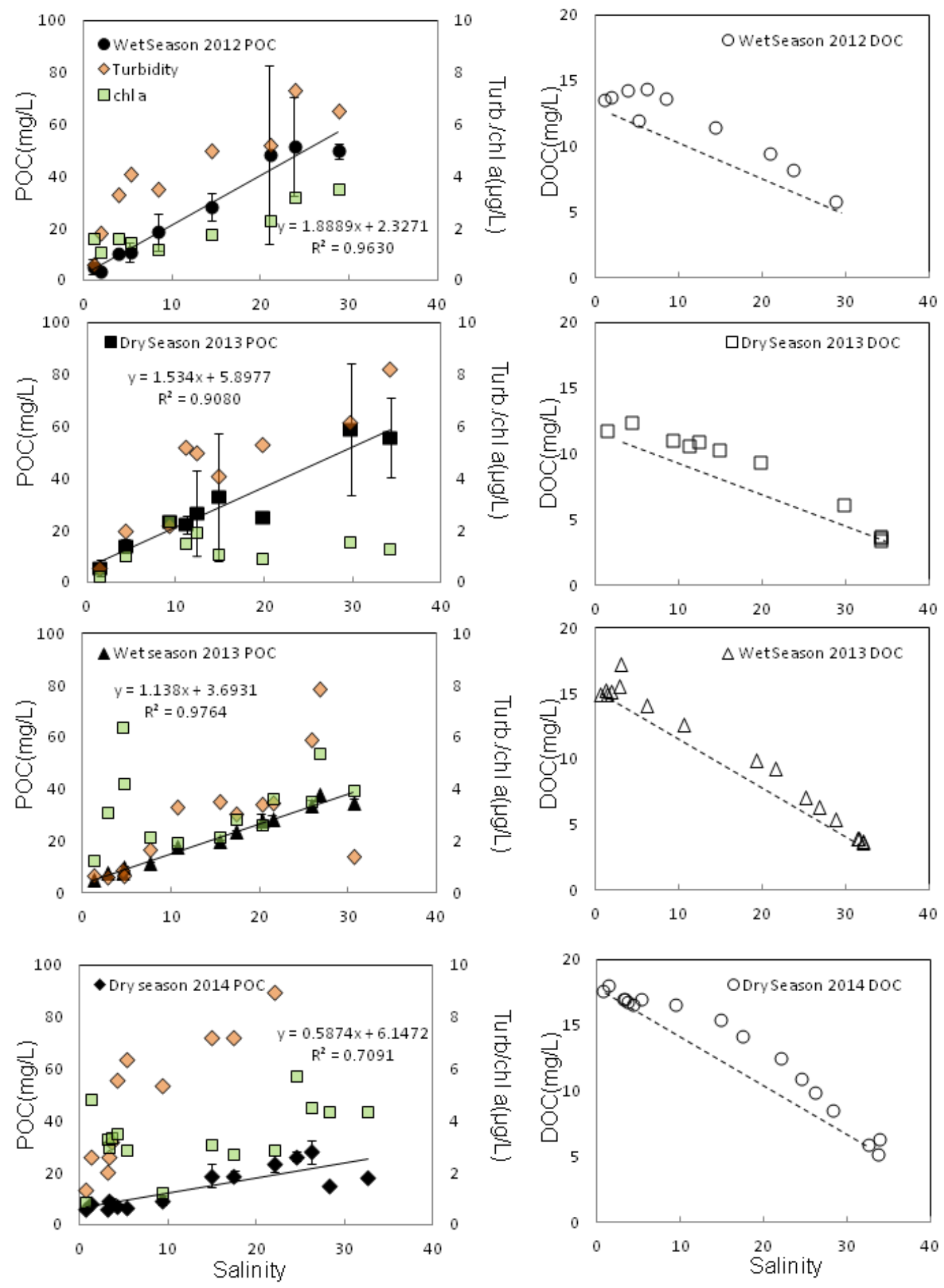

Figure 4.2 Turbidity, POC DOC concentration and Chl- $\alpha$ concentration along Harney River estuary during two dry seasons (Mar. 2013 and 2014) and two wet seasons (Nov.2012 and 2013) 
Table 4.1 Comparative table of POM and DOM characteristics in Shark and Harney river estuary

\begin{tabular}{|c|c|c|c|c|c|}
\hline \multirow{13}{*}{ POM } & & \multicolumn{2}{|c|}{ Shark River } & \multicolumn{2}{|c|}{ Harney River } \\
\hline & & Wet Season & Dry Season & Wet Season & Dry Season \\
\hline & salinity range & 0.53 to 32.07 & 0.93 to 32.38 & 1.16 to 30.65 & 0.79 to 33.66 \\
\hline & Number of samples(n) & 17 & 16 & 28 & 29 \\
\hline & $\begin{array}{l}\text { POC concentration } \\
\text { range }(\mathrm{mg} \mathrm{C} / \mathrm{L})\end{array}$ & 3.6 to 38.4 & 8.41 to 33.7 & 4.8 to 37.9 & 5.7 to 33.9 \\
\hline & distribution along salinity & conservative mixing & conservative mixing & conservative mixing & $\begin{array}{l}\text { Sligntly non-conservative } \\
\text { mixing }\end{array}$ \\
\hline & & $y=1.7701 x+3.1271$ & $\mathrm{y}=1.211 \mathrm{x}+12.148$ & $y=1.7891 x+7.9447$ & \\
\hline & & $\left(\mathrm{R}^{2}=0.9782, \mathrm{p}<0.01\right)$ & $\left(\mathrm{R}^{2}=0.888, \mathrm{p}<0.01\right)$ & $\left(\mathrm{R}^{2}=9502, \mathrm{p}<0.01\right)$ & \\
\hline & $\begin{array}{l}\text { POM: chl } \alpha\left(\mathrm{mg} \cdot \mathrm{L}^{-1} / \mathrm{mg} . \mathrm{L}^{-}\right. \\
\left.{ }^{1}\right)\end{array}$ & $18928 \pm 3911$ & $13136 \pm 2701$ & $12453 \pm 1479$ & $7753 \pm 876$ \\
\hline & $\begin{array}{l}\text { C2\%(terrestrial humic- } \\
\text { like) }\end{array}$ & 0 to $6.1 \%$ & 0 to $6.5 \%$ & 0 to $9.2 \%$ & 0 to $6.3 \%$ \\
\hline & C7\%(protein-like) & $18.8 \%$ to $37.3 \%$ & $16.4 \%$ to $42.3 \%$ & $33.8 \%$ to $53.2 \%$ & $16.1 \%$ to $33.3 \%$ \\
\hline & $\delta^{13} \mathrm{C}(\% \mathrm{o})$ & -29.5 to -15.6 & -35.6 to -29.7 & -27.5 to -20.3 & -34.6 to -30.3 \\
\hline & mangrove export & $c a .95 \%$ & - & $c a .94 \%$ & - \\
\hline & $\begin{array}{l}\text { DOC concentration } \\
\text { range }(\mathrm{mg} \mathrm{C} / \mathrm{L})\end{array}$ & 3.6 to 17.2 & 5.6 to 18.0 & 4.4 to 14.9 & 5.2 to 18.0 \\
\hline & Number of samples (n) & 17 & 16 & 28 & 29 \\
\hline DOM & $\begin{array}{l}\text { distribution along salinity } \\
\mathrm{C} 2 \% \text { (terrestrial humic- }\end{array}$ & $\begin{array}{l}\text { non-conservative } \\
\text { mixing }\end{array}$ & $\begin{array}{l}\text { non-conservative } \\
\text { mixing }\end{array}$ & $\begin{array}{l}\text { non-conservative } \\
\text { mixing }\end{array}$ & non-conservative mixing \\
\hline & like) & $5.1 \%$ to $9.9 \%$ & $6.7 \%$ to $11.8 \%$ & $2.7 \%$ to $9.7 \%$ & $6.0 \%$ to $11.9 \%$ \\
\hline & C7\%(protein-like) & $3.7 \%$ to $8.2 \%$ & $3.3 \%$ to $11.5 \%$ & $3.8 \%$ to $10.7 \%$ & $3.2 \%$ to $9.4 \%$ \\
\hline & $\delta^{13} \mathrm{C}(\% \mathrm{o})$ & -28.4 to -26.6 & -27.2 to -24.0 & -27.5 to -25.3 & -27.7 to -25.0 \\
\hline & mangrove export & ca. $12 \%$ & $c a .4 \%$ & $c a .8 \%$ & ca. $10 \%$ \\
\hline
\end{tabular}


Table 4.2 Sampling information: salinity, hydrological data; OM concentration, distribution pattern, flux calculation and optical properties

* $\mathrm{T}=$ total flux; $\mathrm{M}=$ mangrove export flux

\begin{tabular}{|c|c|c|c|c|c|c|c|c|}
\hline \multicolumn{2}{|c|}{ Sample } & \multirow{2}{*}{$\begin{array}{l}\begin{array}{l}\text { Salinity } \\
\text { Range }\end{array} \\
0.99-28.83\end{array}$} & \multirow{2}{*}{$\begin{array}{c}\begin{array}{c}\text { River Discharge } \\
\left(\mathbf{f t}^{\mathbf{3}} \mathbf{~ s}^{-\mathbf{1}}\right)\end{array} \\
6097\end{array}$} & $\begin{array}{l}\text { Concentration } \\
\text { range }(\mathrm{mg} \mathrm{C} / \mathrm{L})\end{array}$ & \multirow[t]{2}{*}{$\begin{array}{l}\text { Distribution } \\
\text { pattern }\end{array}$} & \multirow{2}{*}{$\begin{array}{c}\text { Flux }\left(\mathbf{m g ~ C . d ^ { - 1 }}\right) \\
2.4 \times 10^{11(\mathrm{~T})}\end{array}$} & \multirow{2}{*}{$\begin{array}{c}\mathbf{S}_{\mathbf{R}} \\
1.05-4.04\end{array}$} & \multirow{2}{*}{$\begin{array}{l}\text { HIX } \\
0.49-0.79\end{array}$} \\
\hline Nov.2012 & POC & & & $5.0-49.7$ & & & & \\
\hline Mar.2013 & POC & $1.41-34.26$ & 1008 & $5.3-47.6$ & conservatively increase & $4.0 \times 10^{10(\mathrm{~T})}$ & $1.63-4.87$ & $0.54-0.81$ \\
\hline Nov.2013 & $\mathrm{POC}$ & $1.16-28.29$ & N.A & $4.7-37.9$ & conservatively increase & N.A & $0.65-4.37$ & $0.30-0.45$ \\
\hline Mar.2014 & $\mathrm{POC}$ & $0.79-33.83$ & -16617 & $5.7-27.0$ & $\begin{array}{c}\text { slightly non-conservative } \\
\text { increase }\end{array}$ & $9.0 \times 10^{11(\mathrm{~T})}$ & $1.51-3.09$ & $0.51-0.67$ \\
\hline Nov.2012 & DOC & $0.99-28.83$ & 6097 & $5.85-13.75$ & $\begin{array}{c}\text { non-conservatively } \\
\text { decrease }\end{array}$ & $1.7 \times 10^{10(\mathrm{~T})} ; 1.7 \times 10^{9(\mathrm{M})}$ & $0.98-1.07$ & $0.89-0.93$ \\
\hline Mar.2013 & DOC & $1.41-34.26$ & 1008 & $3.54-12.38$ & $\begin{array}{c}\text { non-conservatively } \\
\text { decrease }\end{array}$ & $2.5 \times 10^{10(\mathrm{~T})} ; 3.2 \times 10^{9(\mathrm{M})}$ & $0.98-1.14$ & $0.85-0.92$ \\
\hline Nov.2010 & DOC & $1.98-32.35$ & 3696 & $3.92-13.06$ & $\begin{array}{c}\text { non-conservatively } \\
\text { decrease }\end{array}$ & $9.5 \times 10^{9(\mathrm{~T})} ; 1.9 \times 10^{9(\mathrm{M})}$ & $1.01-1.04$ & N.A. \\
\hline Mar.2010 & DOC & $2.67-32.17$ & 4760 & $5.52-17.25$ & $\begin{array}{c}\text { non-conservatively } \\
\text { decrease }\end{array}$ & $1.5 \times 10^{9(\mathrm{~T})} ; 0.2 \times 10^{9(\mathrm{M})}$ & $1.03-1.11$ & N.A. \\
\hline
\end{tabular}




\subsubsection{EEM-PARAFAC characterization for POM base extract}

Table 4.2 summarizes the optical indexes of POM and DOM. The humification index (HIX) can be used to estimate the degree of diagenetic reworking of DOM (Fellman et al., 2010), and ranges from 0 to 1 increasing with increasing degree of humification (Ohno, 2002; Inamdar et al., 2012). DOM showed significantly higher HIX values compared to POM during all sampling seasons (Average $\mathrm{HIX}_{\mathrm{DOM}}=0.89 \pm 0.00$ and HIX $\left._{\mathrm{POM}}=0.58 \pm 0.02 ; \mathrm{p}<0.01\right)$. This suggests that the DOM has a higher degree of humification, higher aromaticity, and is more likely to be degraded and refractory compared to the POM. In contrast, the latter was enriched in OM emitting fluorescence in the lower wavelength region, particularly in tyrosine and tryptophan or other protein-like fluorescence. $\mathrm{HIX}_{\mathrm{DOM}}$ values did not show significant variations between seasons (Table 4.2), suggesting relatively steady source contributions. Compared to DOM, HIX $\mathrm{XOM}_{\mathrm{P}}$ showed a wider range of values along salinity transect (Table 4.1), indicative of source variations or degradation patterns in the POM pool.

The spectral slope ratio $\left(\mathrm{S}_{\mathrm{R}}\right)$ of absorption spectrum can be used as an indicator of DOM molecular weight and source (Helms et al., 2008). POM base-extract showed significantly higher $S_{R}$ values $(p<0.05)$ than for DOM, suggesting that POM constituents are either more degraded and thus featured lower average molecular weights, or that they are more fresh, biomolecules, which showed lower molecular weights compared to the more humified DOM. The latter explanation is in agreement with Tremblay and Gané (2009) who suggested that the freshwater-derived POM pool containing fresher and less recalcitrant material than the corresponding DOM. A general increase in $S_{R}$ value were observed towards the marine end-member suggesting a shift in POM quality to smaller 
compounds likely due to the source change along salinity gradient. Such a pattern could be the result of a shift in POM origin from mangrove to seagrass detritus. Mangrove detritus is known to contained abundant polycondensed tannins (Maie et al., 2008) with larger molecular weight compared to the polyphenols contained in seagrass (Vergeer et al., 1995).

A general decreasing trend along the salinity gradient was observed in both HIX $_{\text {DOM and }} \mathrm{HIX}_{\mathrm{POM}}$, which suggested a shift in OM source material from more humified sources to more "freshly" produced sources towards the ocean. This seems to be in agreement with the $S_{R}$ values discussed above. Source change in POM mixing was found more significant than in DOM (Figure 4.3a) with HIX $\mathrm{POM}_{\mathrm{PO}}$ drastically decreased from $\sim 0.8$ to $\sim 0.5$ towards the lower estuary. Variations in the OM characteristics were also reflected by the change of $S_{R}$ along the salinity gradient (Fig.4.3b). Similar to the HIX, the $S_{R}$ values for the POM showed significant changes from the upper estuary towards the lower estuary (factor of 5) while $S_{R}$ values for the DOM showed less spatial variations. Both $S_{R}$ and HIX patterns suggest a dynamic mixing of POM throughout the estuary likely due to the change in POM sources at the lower estuary (i.e. mangrove vs. seagrass detritus respectively). The increasing contribution of seasgrass detritus at the lower estuary would play a significant role in the change of optical properties of POM pool. In contrast, the patters observed for the DOM agree with the reported dominant freshwater end-member source (Cawley et al., 2014) and only minor contributions from the mangrove fringe. 

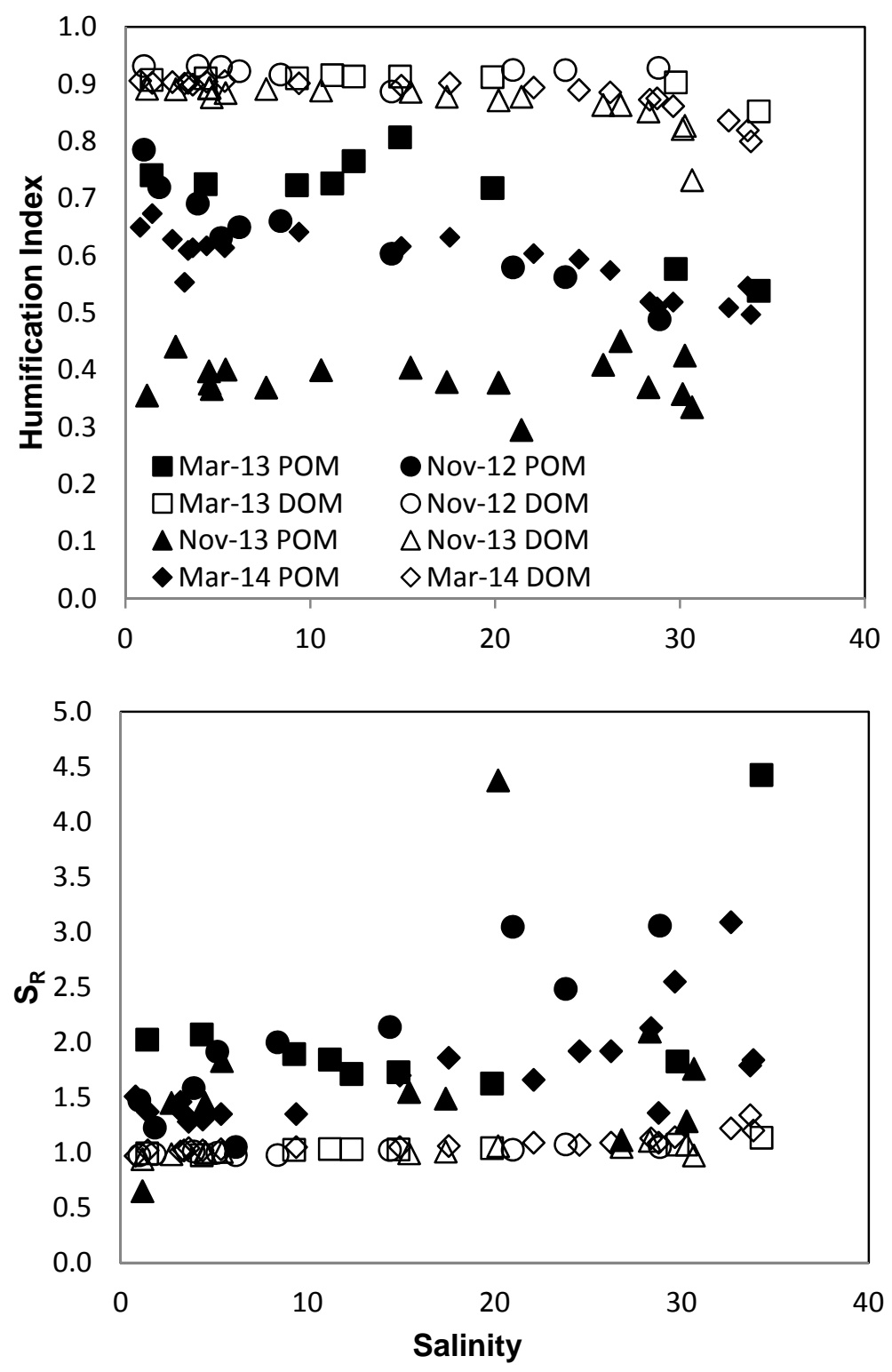

Figure 4.3 $\mathrm{HIX}_{\mathrm{POM}}$ and $\mathrm{HIX}_{\mathrm{DOM}}$ variation along the Harney river salinity transect during four sampling seasons.

Similar to the HIX and $\mathrm{S}_{\mathrm{R}}$, the EEM characteristics of neutralized base-extracts of POM showed distinctly different features from DOM. The fluorescence intensity (normalized to the volume of water filtered) of the POM extract was much lower than the 
corresponding DOM (POM total fluorescence is $\sim 10 \%$ of DOM total fluorescence). EEMs of POM base extracts showed to be more enriched in labile substrates ( $\mathrm{T}$ and $\mathrm{M}$ peak) relative to DOM, a signal which is maintained during mixing in the estuary. DOM showed a common feature in which the major fluorescence region is peak A (Ex $260 \mathrm{~nm}$; Em $460 \mathrm{~nm}$ ) elongated with peak M (Ex 305 nm; Em 402 nm) and C peak (Ex 320-360 nm; Em 420-460 nm). Compared with DOM, POM showed less elongation between the $\mathrm{A}$ and $\mathrm{M}$ peaks, which is also reported in the fluorescence fingerprinting of POM base extract in another river-dominated estuary (Osburn et al., 2010).

At freshwater sites, EEMs of POM exhibited a significant A peak abundance, which is traditionally considered as originating from allochthonous/terrestrial sources, with a distinguishable M peak clearly separated from the A peak (Fig. 4.4a). Compared with freshwater, EEMs of POM at the lower estuary showed a more blue-shifted spectrum, suggesting a distinct change in POM quality from upper estuary towards ocean. EEMs of POM at the lower estuary exhibit an intense T fluorescence (Ex 280; Em 325) (Fig. 4.4c), which generally is assigned to tryptophan and/or tyrosine like fluorescence (Coble 1996), while the DOM EEMs shifted to short-wavelength region but did not show a distinctly separated protein-like region (Fig. 4.4d). The enrichment in the protein-like fluorescence of the base extracts of POM compared to the DOM again suggests a decoupling between the POM and DOM source contributions in the estuary. The proteinlike fluorescence in the POM may be derived from the presence of labile proteins, peptides, or amino acids in plant detritus or polyphenols such as tannins (Maie et al., 2007). While the former may be more bioavailable in the dissolved form, the latter have been found to be highly photo-reactive (Maie et al., 2010), and thus neither accumulate as 
well in DOM. This data suggests that in agreement with the HIX values, the EEMs for the POM are characteristic for more 'fresh' OM compared to the DOM.

EEMs of POM and DOM were fitted to an established EEM-PARAFAC model developed for the Everglades (Yamashita et al., 2010; Chen et al., 2010). This model was based on a large number of samples $(n=1394)$, which has subsequently been used to characterize DOM quality and quantity within the Florida Coastal Everglades (Chen et al., 2013; Cawley et al., 2014). To best compare POM and DOM fluorescence characteristics, the EEMs of the POM base extracts were directly fitted to this established model. The existence of significant residuals was observed, indicating the presence of fluorescent components in the POM which are not well represented in DOM model (Figure 4.4a). As shown in Fig.4.4a, significant peaks (Residue $>10 \%$ of $F_{\max }$ ) were found in the region of the $T^{\prime}$ peak (Ex250-280 nm, Em320-340 nm) and M' peak (Ex280$300 \mathrm{~nm}, \mathrm{Em} 400-420 \mathrm{~nm})$. Since the residuals were not observed in surface water DOM samples, POM is suggested to contain labile components that do not accumulate in DOM or are not readily soluble in natural water. In the POM base extract, PARAFAC identified seven out of eight components which were previously found in surface water DOM, including five humic-like components $(\mathrm{C} 1, \mathrm{C} 3, \mathrm{C} 4, \mathrm{C} 5, \mathrm{C} 6)$ and two protein-like components (C7, C8). Interestingly, component C2 was absent in POM (Fig. 4.5). This component had previously been assigned as a photo-refractory, humic-like substance primarily derived from agricultural lands in the northern Everglades system (Yamashita et al., 2010). C2 has been reported to follow conservative mixing in the Harney River estuary DOM pool (Cawley et al., 2014), suggesting an absence of additional sources in 
the fringe mangrove swamps. Its absence in the POM base extracts is therefore expected since transfer of POM from the freshwater marshes to the estuaries is believed to be minimal (He et al., 2014). The most abundant PARAFAC component in Everglades DOM, the terrestrial humic-like component $\mathrm{C} 1$, also showed significant difference between POM and DOM (Fig.4.5, asterisk mark indicate significant difference between POC and DOC), featuring lower relative abundances of this component in the POM pool compared to DOM. As shown by Fig.4.5, there is significantly higher relative abundance of $\mathrm{C} 7$ and $\mathrm{C} 8$ in POM compared to DOM (Fig. 4.5; $<<0.05$, independent t-test, two tailed). C7 is a protein-like (tyrosine) component with shorter emission wavelength compared with C8 (tryptophan). In previous studies of DOM in Everglades, C7 was suggested to be mostly biomass-derived and showed higher relative abundance values in Florida Bay (Yamashita et al., 2010; Chen et al., 2013). Based on previous DOM fluorescence work along the Harney and Shark transects, protein-like component (C7) showed relative abundances below $6 \%$ and behaved non-conservatively along the salinity gradient possibly due to biodegradation at higher salinities (Cawley et al., 2014). In this study, however, while C7 abundance in DOM was still low, C7 values were generally high in all POM samples (>30\%, Fig.4.5). While the protein-like components have been suggested to be associated with biomass primary productivity and likely derived from marine phytoplankton and seagrass (Maie et al., 2006;Yamashita et al., 2010; Chen et al., 2013), considering the high POM:Chl-a ratio (Table 4.1) observed in this study, plantderived detritus might be more important as a POM source compared to marine phytoplankton for $\mathrm{C} 7$ and $\mathrm{C} 8$. While seagrasses have been reported to leach significant amounts of protein-like DOM (Chen et al., 2014), mangroves seem to be a likely source 
of POM in the upper to middle estuary. While mangrove detritus likely contains proteinlike OM, the protein-like fluorescence might be derived from the presence of polyphenols such as tannins (Maie et al., 2008). The implications for these source differences are discussed in the next chapter.
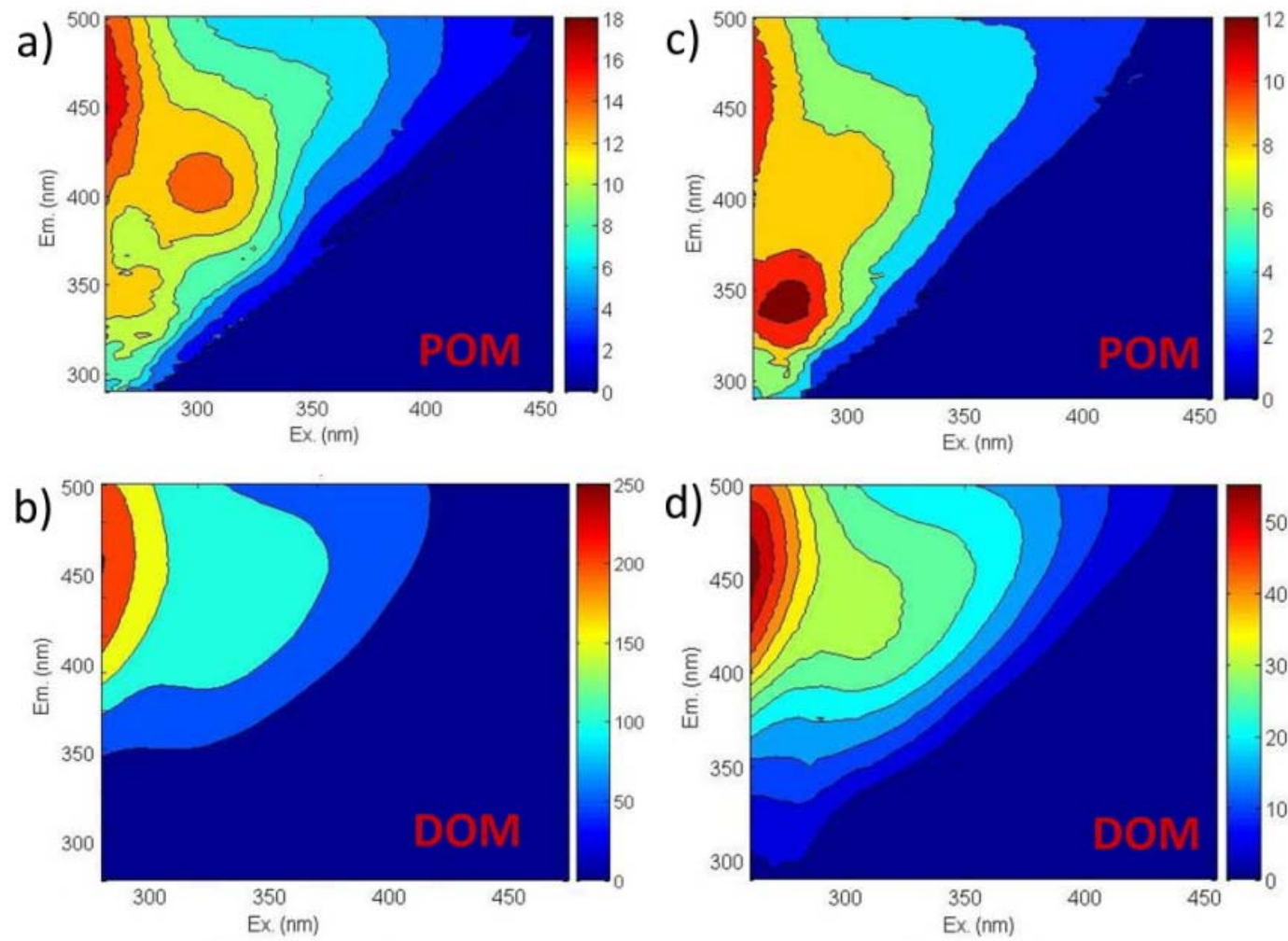

Fresh water

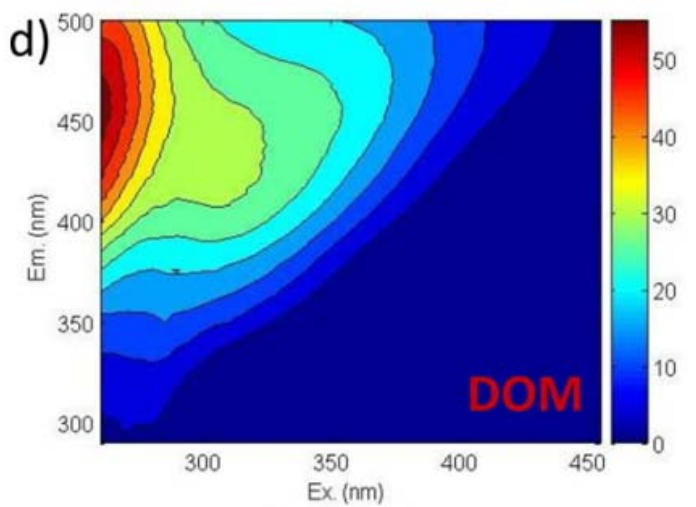

Sea water

Figure 4.4a EEMs of DOM and POM in fresh water and seawater: (a) fresh water POM; (b) fresh water DOM; (c) sea water POM; (d) sea water DOM 

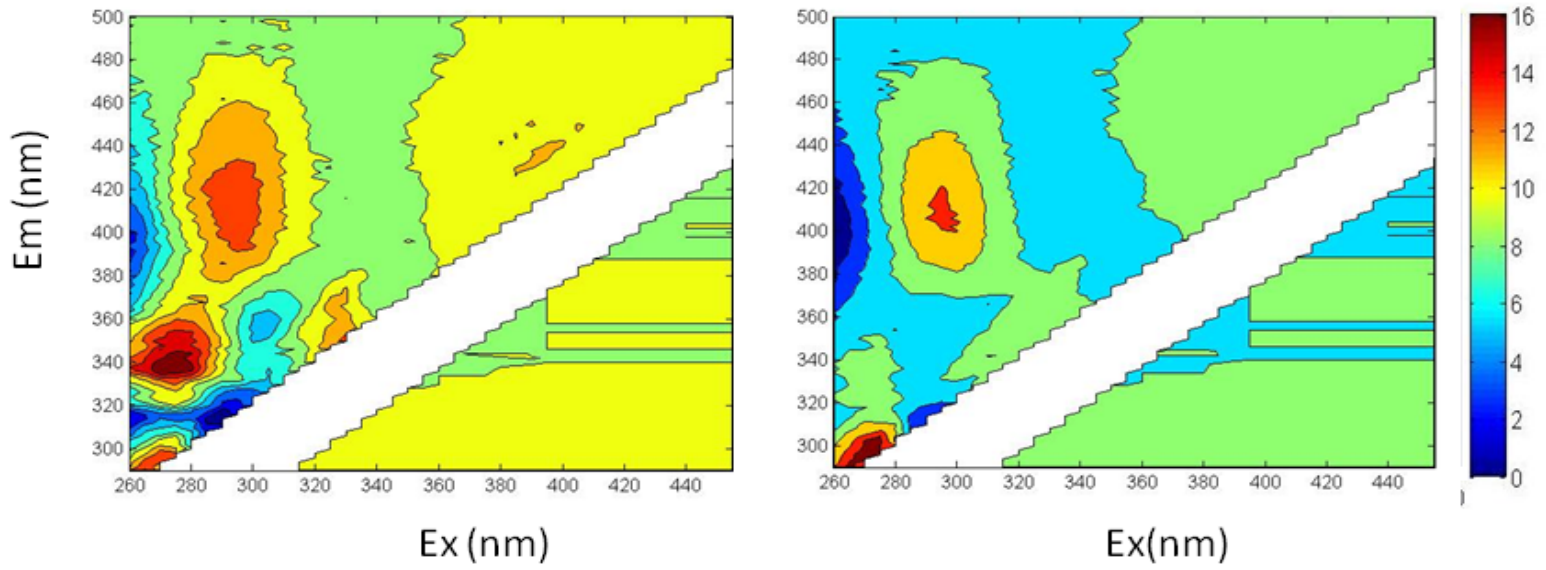

Figure 4.4b Residual components for the EEMs of POM base-extract.
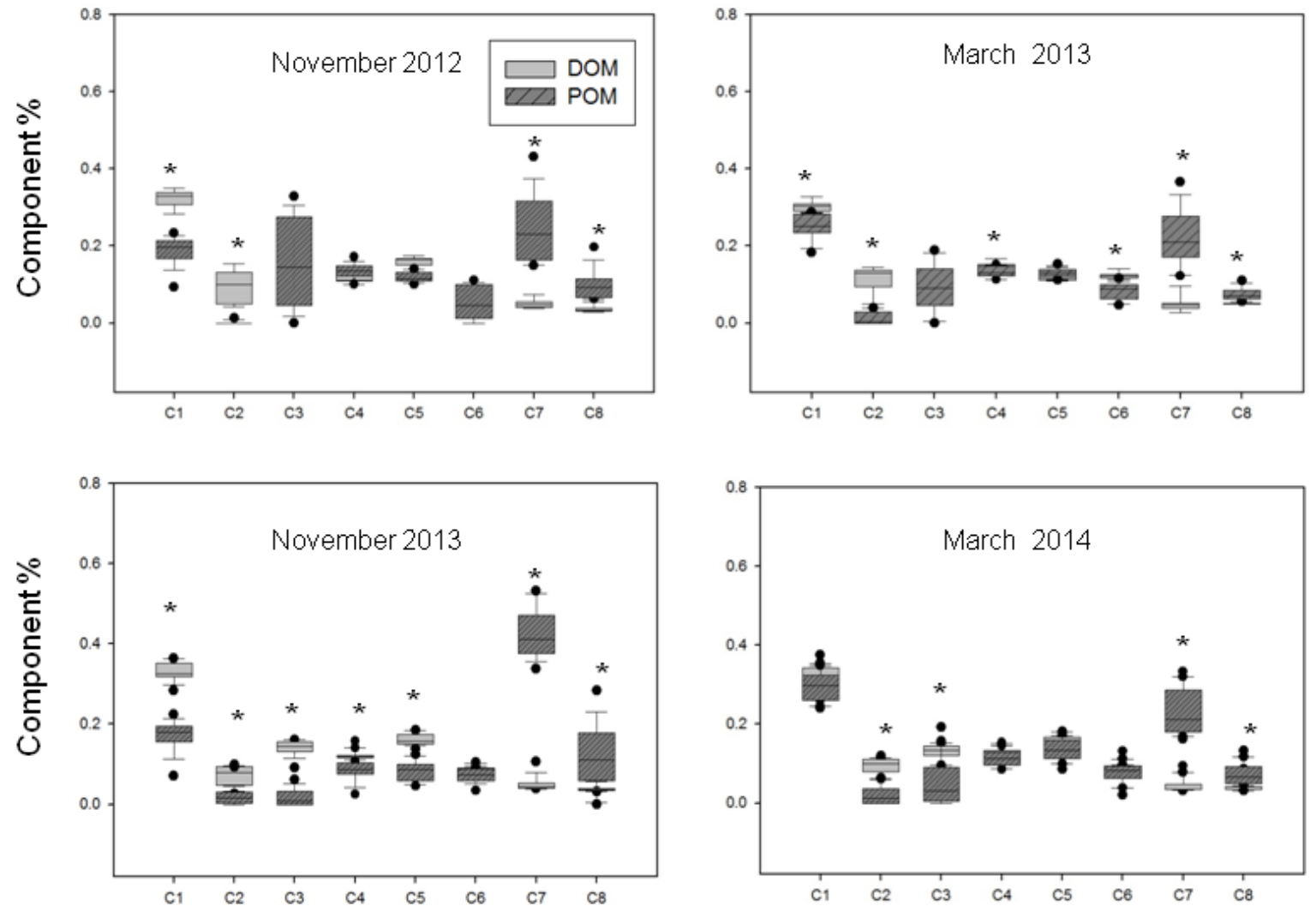

Figure 4.5 Relative abundance of EEM-PARAFAC components of POM and DOM in wet and dry seasons. 
To further analyze the EEM PARAFAC results, the relative abundances of the 8 different components were analyzed using principal components analysis (PCA, Figure 4.6). The first principal component (PC1) accounted for about $54 \%$ of the variability of the data, while PC2 accounted for an additional 20\%. The protein-like components C7 and $\mathrm{C} 8$ were correlated negatively with PC1 (left side), while the humic-like C1, C2, C3, and $\mathrm{C} 5$ components were correlated positively (right side) along PC1, suggesting that PC1 may be a proxy for OM sources. Similar observations had been made using PCA and the Everglades PARAFAC model in other local studies (Chen et al., 2013; Cawley et al., 2014). Along PC2 (19.9\%), the microbial humic-like components C4 and C6, the latter a photo-labile component (Chen et al., 2010; Cawley et al., 2014), showed the most positive values, suggesting that positive PC2 values represent more freshly produced, labile OM. Along the negative side of $\mathrm{PC} 2$, were $\mathrm{C} 3$ and $\mathrm{C} 5$, both soil-derived humic-like components, which are relatively refractory and commonly observed in surface water. Photo-induced transformations of OM from Florida coastal Everglades have been reported as an important degradation pathway and have significant effect on OM processing on a short timescale (Chen and Jaffé, 2014). Thus, PC2 seems related to the diagenetic processing of organic matter. Similar PCA results have been reported in previous study on the long term monitoring of DOM characteristics in Everglades where DOM sources and degradation degree were identified as the major controlling factors of DOM dynamics (Chen et al., 2013; Chen and Jaffé, 2014).

POM and DOM showed distinct differences in their EEM-PARAFAC composition based on the observed PC1 distribution. POM was enriched in protein-like 
components showing negative PC1 values, in contrast to the DOM which clustered at more positive $\mathrm{PC} 1$ values, mainly associated with the terrestrial humic-like components. DOM showed distinct seasonal differences in composition. During the wet season, DOM composition shifted to labile component (positive PC2), possibly due to enhanced groundwater/porewater input which contained more photo-sensitive and less altered compound (i.e. C6) (Chen et al., 2013; Cawley et al., 2014). In contrast, seasonality patterns for POM were different, with about an equal spread of loadings for PC2, but more negative PC1 values during the wet season compared to the dry season. The dynamic mixing of POM of different degree of degradation was also reflected by the HIX values as previously described (Fig.4.3). The data shows no significant changes in the HIX value along the salinity gradient for the DOM, but a significant decrease for the POM. Thus, while DOM seems mainly to be exported from the upper, freshwater marsh end-member (Cawley et al., 2014) with no significant changes in source strength or diagenetic transformations, the 'freshness' of the POM increased significantly along the estuary. Again, this suggests a shift from a dominant terrestrial, higher plant source (most likely mangroves) in the upper estuary to a marine (most likely seasgrass) source in the lower estuary. 


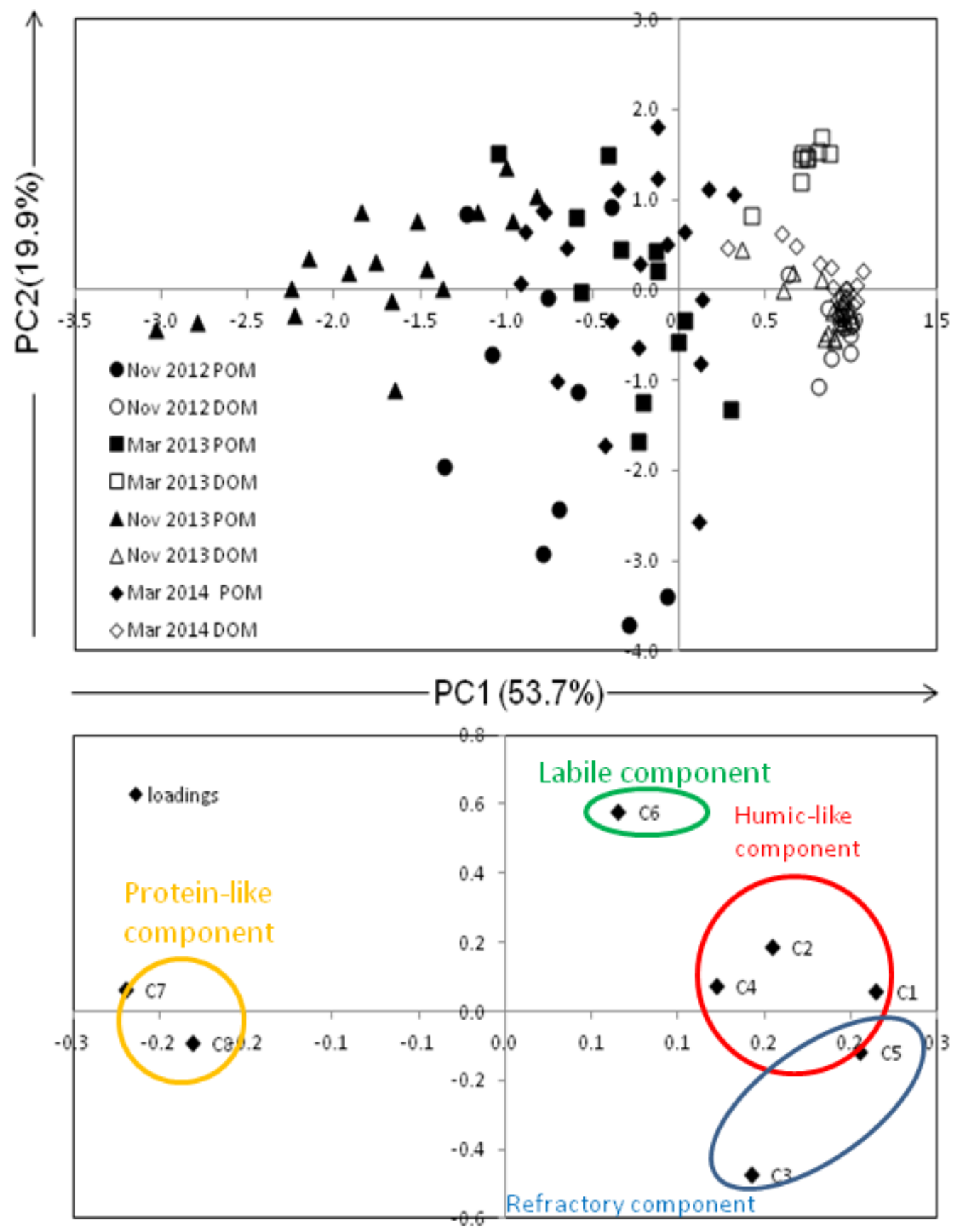

Figure 4.6 PCA analysis of POM and DOM along Harney River based on relative abundance of PARAFAC components. 


\subsubsection{Isotopic source characterization}

Stable isotope ratios $\left(\delta^{13} \mathrm{C}\right)$ of POM showed both temporal and spatial variations along the Harney and Shark salinity gradient (Fig. 4.7). POM tended to be significantly more depleted in $\delta^{13} \mathrm{C}(-30.1 \pm 0.8 \%$ ) (independent t-test, $\mathrm{p}<0.01)$ during the dry season than the wet season $(-25.7 \pm 0.5 \%)$. The depletion in $\delta^{13} \mathrm{C}$ observed during the dry season could be caused by isotopic fractionation during early diagenesis, where significant loss of ${ }^{13} \mathrm{C}$-enriched carbohydrates occurred due to longer water residence time controlling the intermolecular mass balance of ${ }^{13} \mathrm{C}$ in POM. An overall depletion of up to about $4 \%$ in the $\delta^{13} \mathrm{C}$ values of the organic matter has been reported as a result of such early diagenesis (Spiker and Hatcher, 1984). Spatially, there is a seaward enrichment for both Shark and Harney transects (Fig.4.7). The freshwater sites showed relatively depleted $\delta^{13} \mathrm{C}$-POC values with $-25.8 \%$ during wet season and $-31.4 \%$ during dry season, while the $\delta^{13} \mathrm{C}$-POC values at the marine sites showed the most enriched isotopic values, with $22.1 \%$ during wet season and $-29.5 \%$ during dry season. Similar observations were found in a previous study on POM in the Delaware Bay estuary, where the values of $\delta^{13} \mathrm{C}$-POC were more depleted in the riverine end- member than marine end-member due to the inputs of terrestrial OC (Cifuentes et al., 1996; Cifuentes et al., 1988). While an isotopic enrichment could be possibly attributed to enhanced marine phytoplankton contributions, the highly enriched values suggest that inputs due to seagrass detritus are more likely towards the Gulf of Mexico (Fig.4.7). In addition, the high POM/Chl-a ratios also imply that planktonic sources are very small compared to higher plant detritus. $\delta^{13} \mathrm{C}$ values in the range from -16.4 to $-9.6 \%$ have previously been reported for seagrass 
detritus (Williams et al., 2009). Our observed values for $\delta^{13} \mathrm{C}$-POC of $-19.7 \%$ at lower estuarine site (during the wet season 2012) are indicative of seagrass detritus mixed with mangrove detritus. Tidal exchange likely introduces seagrass detritus into the study area, which ultimately influences the POM isotopic signature towards the marine end-member. The presence of seagrass-derived OM in sediments off Ponce de Leon Bay has previously been reported (Hernandez et al., 2001).

Spatially, the $\delta^{13} \mathrm{C}$-POC distribution showed a depletion in the mid-estuary region (Fig.4.7; -27.6\% for Harney River and $-27.1 \%$ for Shark River), indicative of enhanced fringe mangrove contribution to the POC pool. Mangrove biomass values were reported to be highest close to the mouth of Shark and Harney River (Rivera-Monroy et al., 2011). Highest contributions of mangrove-derived OM in this region of the estuary have also been reported by He et al. (2014). Thus, the depleted isotopic values found in the mangrove influenced area was probably the result of mangrove outwelling (Odum, 1968) likely mixed with some undetermined contributions from plankton. Significant amounts of mangrove-derived POM are therefore likely to accumulate in the mid-to-lower estuary. Mangrove litterfall in oligotrophic estuaries represents a relatively large source of organic matter (Benner and Hodson, 1985; Benner et al., 1986). In South Florida, peak litterfall occurs from August to October after increases in soil water salinity during June and July (Twilley et al., 1986). The average $\delta^{13} \mathrm{C}-\mathrm{POC}$ value was similar in both Shark and Harney river transects (Table 4.1) with slightly more enriched values in the freshwater sites (Harney River:-25.9\%; Shark River:-25.8\%o). This enrichment might be caused by the contribution from freshwater marsh derived floc, which contains significant remains of 
periphyton (Pisani et al., 2013; Neto et al., 2006) and has been reported to reach the estuary (Jaffé et al., 2008), although in relatively minor quantities (He et al., 2014).

Compared with $\delta^{13} \mathrm{C}-\mathrm{POC}, \delta^{13} \mathrm{C}-\mathrm{DOC}$ showed a relatively narrow range of variation (Table 4.1 and Fig.4.7) suggesting a less dynamic mixing of isotopically distinct materials. This agrees with our previously described optical measurements (Fig.4.3 and Table 4.2) that both POM-S $\mathrm{S}_{\mathrm{R}}$ and POM-HIX featured more significantly variable compared with DOM optical parameters. More enriched $\delta^{13} \mathrm{C}$-DOCvalues were consistently found at the lower estuary (-24.5\%o in marine end-member), while the seaward enrichment in $\delta^{13} \mathrm{C}-\mathrm{DOC}$ values was not as significant compared with POM (Fig 4.7 and Table 4.1). The Harney River samples showed an average $\delta^{13} \mathrm{C}$-DOC values of $26.7 \pm 0.5 \%$ (Wet 2013) and $-26.7 \pm 0.8 \%$ (Dry 2014), while the Shark River samples showed an average isotopic value of $-26.8 \pm 1.0 \%$ (Wet 2013) and $-26.2 \pm 0.9 \%$ (Dry 2014). Depletion in $\delta^{13} \mathrm{C}$-DOCwas observed in the mid-estuary (Fig.4.7) as a result of increased mangrove-derived inputs. This depletion is particularly evident during wet season due to the enhanced outwelling of mangrove-derived OC (Romigh et al., 2006). Overall, the isotopic source characterization agrees with the PARAFAC results in that DOM is mainly derived from terrestrial sources while POM sources mostly derive from mangrove detritus with additional seagrass input in the lower estuary 

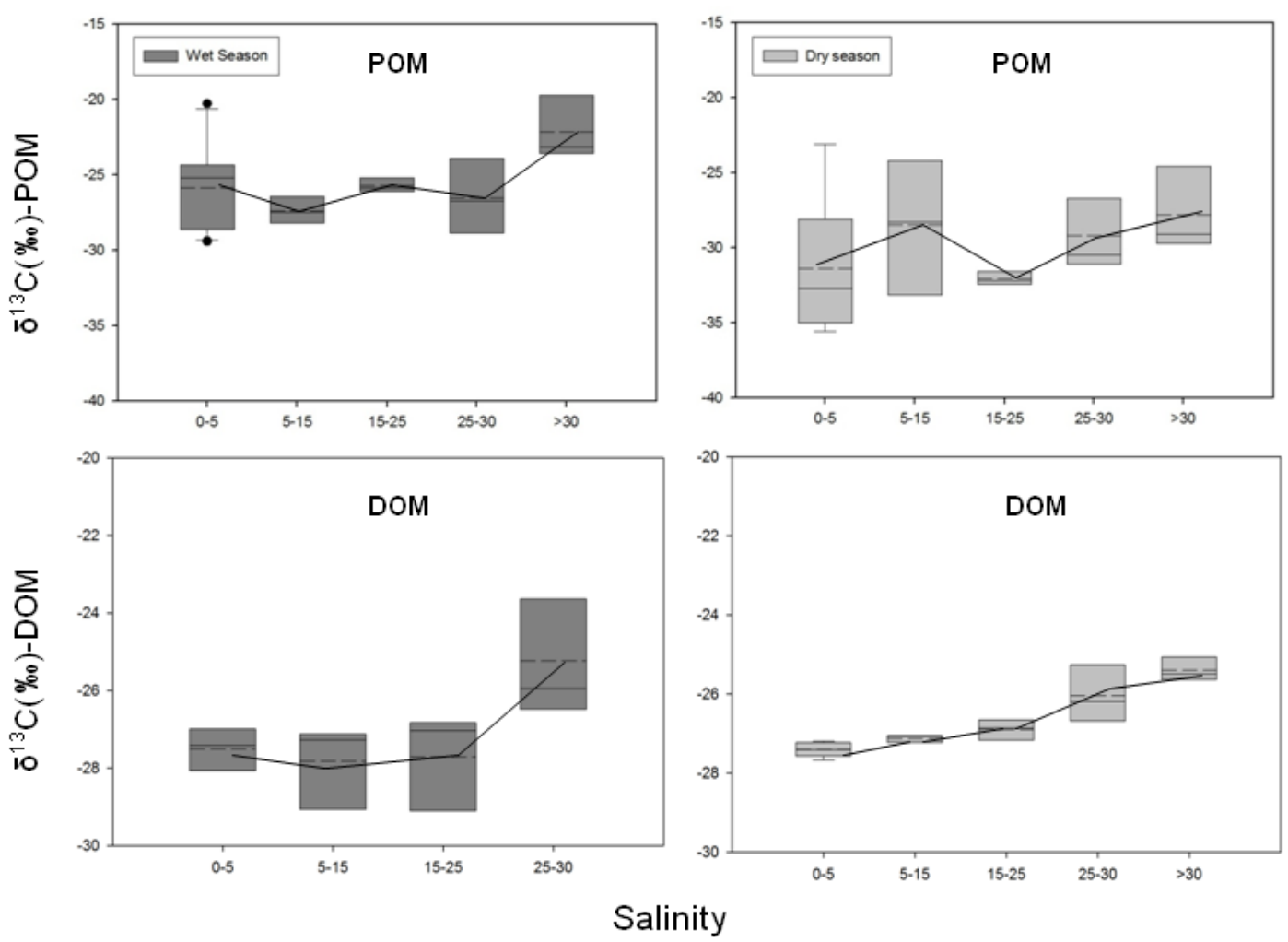

Figure 4.7 Spatial distribution of POC- $\delta{ }^{13} \mathrm{C}$ isotope along Harney and Shark salinity transects

\subsubsection{Mangrove-derived DOM and POM export estimate}

Based on the above-described bulk feature and isotopic mass balance calculation (4.3), we reached the conclusion that the majority of POM is exported from mangrove $(\sim 90 \%)$. This estimate is reasonable since POM values for the freshwater Everglades are reported to be very low (Childers et al., 2006) and previous biomarker study has given a similar estimate as: freshwater-derived POM, 1-8\%; mangrove-derived POM, 70-90\%; marine-derived POM, 6-20\% (He et al., 2014). The total OM flux and mangrove exported POM flux was calculated here as: 
Mangrove-derived POC flux $=\varnothing \times[\mathrm{POM}] \times 0.90 \times 0.58$

$\varnothing$ is the constituent flux (water discharge) calculated for the particular sampling day, $[\mathrm{POM}]$ is the POM concentration collected at the closest station to the river discharge monitoring station. This value is corrected for the relative contribution of mangroves to the POM pool $(90 \%)$ and the $58 \%$ corresponds to the transformation of POM to POC. Daily POC flux value is showed in Table 4.2. On an annual basis, the mangrove-exported POC flux was estimated as $1.7 \times 10^{7}$ to $3.7 \times 10^{8} \mathrm{~kg}$ POC $/ \mathrm{yr}$, which showed larger order of magnitude by a factor of 1-2 compared with previous estimate in Shark River by He et al., $2014\left(9.2 \times 10^{5}\right.$ to $1.8 \times 10^{6} \mathrm{~kg}$ POC $\left./ \mathrm{yr}\right)$. The variation in POC flux could be caused by several environmental factors (i.e. seasonality, tidal stage, wind etc.) or the limited number of samples for determination of POM concentration. Flux estimates for mangrove-derived DOC were at a similar order of magnitude (different in order of magnitude by 1) compared with the total POM flux during the study period (Table 4.2). In agreement, similar observations and estimates on the fluxes of DOC and POC from mangrove export were also reported for the Shark River estuary (Cawley et al., 2014; He et al., 2014). In several other estuaries, mangrove-derived POC and DOC export were reported in similar proportions as well (Tue et al., 2012; Dittmar et al., 2001).

\subsection{Conclusions}

The importance of the contribution of mangrove derived OM to subtropical and tropical coastal estuaries has long be recognized (Dittmar et al., 2006; Bouillon et al., 2008; Bergamaschi et al., 2011). Our study on the mangrove influence on carbon export 
in the estuaries of South Florida, suggest that the mangrove-dominated ecotone likely serves as the main source of POM accounting for $c a . \sim 90 \%$ of POM pool in the studied region. Both fluorescence and stable $\mathrm{C}$ isotope of POM exhibit strong source signature change from mangroves in the upper estuary, to a seagrass detritus influenced signature towards the lower estuary, where POM exported by mangrove and seagrass communities has been reported as coupled tightly (Slim et al., 1994). These dynamics are very different compared with other estuaries and coastal-ocean ecosystems where POM was found primarily originated from planktonic sources and thus showed an increasing trend seaward (Harvey and Mannino, 2001; Osburn et al., 2010; Brym et al., 2014). As reflected by the flux values, DOM and POM were exported from the mangrove to the estuary in similar proportions, although the bulk DOM is freshwater-derived in these estuaries (Cawley et al., 2014). Similar results were reported for the Shark River estuary in a previous study using molecular biomarkers (He et al., 2014), and also observed in mangrove-fringed estuaries elsewhere (Dittmar et al., 2001). Therefore, mangroves play a crucial role in the aquatic carbon budget in subtropical coastal estuaries. The export of these large amounts of mangrove-derived OM can have a detectable effect on the food web dynamics in coastal waters (Alongi et al., 1989; Alongi 1990). The dynamics of bulk POM and DOM are largely uncoupled in this system mainly due to the source difference, where freshwater discharge and to a lower extent tidal pumping, generate most of the DOM. Humic substances of DOM are primarily terrestrial derived with a smaller mangrove-derived portion ( 10-20\%) (Cawley et al., 2014) and $4-12 \%$ in this study, while freshwater marsh/terrestrially derived OM material does not seem to have much of an influence on the POM pool (see also He et al., 2014). Globally, DOC export 
from mangrove swamps accounts for $10 \%$ of the terrestrial flux to coastal oceans (Dittmar et al., 2006; Bouillon et al., 2008). Although similar flux values for mangrovederived POC have been suggested (Dittmar and Lara 2001; Dittmar et al., 2001), including for the estuaries in the Everglades (He at al., 2014), the uncoupling between bulk DOM and POM reported here needs to be taken into consideration when estimates on wider spatial scales are used in carbon flux models and in the assessment of food webs. 


\section{REFERENCES}

Alongi, D.D., 1990. Abundances of benthic microfauna in relation to outwelling of mangrove detritus in a tropical coastal region. Marine Ecology Progress Series-pages 63, 53-63.

Alongi, D.M., Boto, K.G. and Tirendi, F., 1989. Effect of exported mangrove litter on bacterial productivity and dissolved organic carbon fluxes in adjacent tropical nearshore sediments. Marine ecology progress series. Oldendorf 56, 133-144.

Aufdenkampe, A.K., Hedges, J.I., Richey, J.E., Krusche, A.V. and Llerena, C.A., 2001. Sorptive fractionation of dissolved organic nitrogen and amino acids onto fine sediments within the Amazon Basin. Limnology and Oceanography 46, 1921-1935.

Benner, R., Fogel, M., Sprague, E. and Hodson, R., 1987. Depletion of C in lignin and its implications for stable carbon isotope studies. Nature 329, 708-710.

Benner, R., Hatcher, P. G., Hedges, J. I., 1990. Early diagenesis of mangrove leaves in a tropical estuary: Bulk chemical characterization using solid-state ${ }^{13} \mathrm{C}$ NMR and elemental analyses. Geochimica et Cosmochimica Acta, 54,2003-2013.

Bianchi, T. and Bauer, J., 2011. Particulate Organic Carbon Cycling and Transformation 5. $69-117$

Bianchi, T.S., Baskaran, M., DeLord, J. and Ravichandran, M.,1997. Carbon cycling in a shallow turbid estuary of southeast Texas: The use of plant pigment biomarkers and water quality parameters. Estuaries 20, 404-415.

Bianchi, T.S., Mitra, S. and McKee, B.A., 2002. Sources of terrestrially-derived organic carbon in lower Mississippi River and Louisiana shelf sediments: implications for differential sedimentation and transport at the coastal margin. Marine Chemistry 77, 211223.

Bristow, L. A., Jickells, T. D., Weston, K., Marca-Bell, A., Parker, R., Andrews, J. E., 2013. Tracing estuarine organic matter sources into the southern North Sea using $C$ and $\mathrm{N}$ isotopic signatures. Biogeochemistry 113, 9-22.

Brym, A., Paerl, H. W., Montgomery, M. T., Handsel, L. T., Ziervogel, K., Osburn, C. L., 2014. Optical and chemical characterization of base-extracted particulate organic matter in coastal marine environments. Marine Chemistry 162, 96-113.

Bouillon, S., Borges, A. V., Castañeda-Moya, E., Diele, K., Dittmar, T., Duke, N. C., Kristensen, E., Lee, S.Y., Marchand,C., Middelburg, J.J.,Rivera-Monroy, V.H.,Smith III, T.J .,Twilley, R. R., 2008. Mangrove production and carbon sinks: a revision of global budget estimates. Global Biogeochemical Cycles 22. GB2013. 
Boyer, J.N., Fourqurean, J.W., Jones, R.D., 1997. Spatial characterization of water quality in Florida Bay and Whitewater Bay by multivariate analyses: zones of similar influence. Estuaries 20, 743-758.

Benner, R., Peele, E.R., Hodson, R.E., 1986. Microbial utilization of dissolved organic matter from the leaves of the red mangrove,Rhizophora mangle, in the Fresh Creek Estuary, Bahamas. Estuary Coastal and Shelf Science. 23, 607-619.

Canuel, E.A., 2001. Relations between river flow, primary production and fatty acid composition of particulate organic matter in San Francisco and Chesapeake Bays: a multivariate approach. Organic Geochemistry 32, 563-583.

Cawley, K.M., Yamashita, Y., Maie, N. and Jaffé, R., 2014. Using Optical Properties to Quantify Fringe Mangrove Inputs to the Dissolved Organic Matter (DOM) Pool in a Subtropical Estuary. Estuaries and Coasts 37, 399-410.

Chao, B.F., 1988. Excitation of the Earth's polar motion due to mass variations in major hydrological reservoirs. Journal of Geophysical Research: Solid Earth 93, 13811-13819.

Chen, M., Price, R.M., Yamashita, Y. and Jaffé, R., 2010 Comparative study of dissolved organic matter from groundwater and surface water in the Florida coastal Everglades using multi-dimensional spectrofluorometry combined with multivariate statistics. Applied Geochemistry 25, 872-880.

Chen, M., Maie, N., Parish, K. and Jaffé, R., 2013. Spatial and temporal variability of dissolved organic matter quantity and composition in an oligotrophic subtropical coastal wetland. Biogeochemistry 115, 167-183.

Chen, M., Jaffé, R., 2014. Photo-and bio-reactivity patterns of dissolved organic matter from biomass and soil leachates and surface waters in a subtropical wetland. Water Research 61, 181-190

Childers, D.L., Boyer, J.N., Davis, S.E., Madden, C.J., Rudnick, D.T. and Sklar, F.H. ,2006 Relating precipitation and water management to nutrient concentrations in the oligotrophic "upside-down" estuaries of the Florida Everglades. Limnology and Oceanography 51, 602-616.

Cifuentes, L., Coffin, R., Solorzano, L., Cardenas, W., Espinoza, J. and Twilley, R., 1996. Isotopic and elemental variations of carbon and nitrogen in a mangrove estuary. Estuarine, Coastal and Shelf Science 43, 781-800.

Cifuentes, L., Sharp, J. and Fogel, M.L., 1988. Stable carbon and nitrogen isotope biogeochemistry in the Delaware estuary. Limnol. Oceanogr 33, 1102-1115. 
Clough, B., 1998. Mangrove forest productivity and biomass accumulation in Hinchinbrook Channel, Australia. Mangroves and Salt Marshes 2, 191-198.

Coble, P.G., 2007. Marine optical biogeochemistry: The chemistry of ocean color. Chemical Reviews 107, 402-418.

Cory, R.M. and McKnight, D.M., 2005. Fluorescence spectroscopy reveals ubiquitous presence of oxidized and reduced quinones in dissolved organic matter. Environmental Science \& Technology 39, 8142-8149.

Cowie, G. and Hedges, J., 1992. The role of anoxia in organic matter preservation in coastal sediments: relative stabilities of the major biochemicals under oxic and anoxic depositional conditions. Organic Geochemistry 19, 229-234.

Czitrom, S.P. ,1986. The effect of river discharge on the residual circulation in the eastern Irish Sea. Continental Shelf Research 6, 475-485.

Chen, M.,Jaffé, R., 2014. Photo-and bio-reactivity patterns of dissolved organic matter from biomass and soil leachates and surface waters in a subtropical wetland. Water Research 61, 181-190

Dauwe, B. and Middelburg, J.J., 1998.Amino acids and hexosamines as indicators of organic matter degradation state in North Sea sediments. Limnology and Oceanography $43,782-798$.

Dauwe, B., Middelburg, J.J., Van Rijswijk, P., Sinke, J., Herman, P.M.J. and Heip, C.H.R., 1999. Enzymatically hydrolyzable amino acids in North Sea sediments and their possible implication for sediment nutritional values. Journal of Marine Research 57, 109134.

Dittmar, T., Lara, R.J. and Kattner, G., 2001. River or mangrove? Tracing major organic matter sources in tropical Brazilian coastal waters. Marine Chemistry 73, 253-271.

Dittmar, T.,Lara, R. J., 2001. Do mangroves rather than rivers provide nutrients to coastal environments south of the Amazon River? Evidence from long-term flux measurements. Marine Ecology Progress Series 213, 67-77.

Dittmar, T., Hertkorn, N., Kattner, G., Lara, R. J., 2006. Mangroves, a major source of dissolved organic carbon to the oceans. Global Biogeochemical Cycles, 20. GB1012.

Dittmar, T., Koch, B., Hertkorn, N., Kattner, G., 2008. A simple and efficient method for the solid-phase extraction of dissolved organic matter (SPE-DOM) from seawater. Limnology Oceanography Methods 6, 230-235.

Droppo, I. G., 2001. Rethinking what constitutes suspended sediment. Hydrological processes 15, 1551-1564. 
Eisma, D., 1986. Flocculation and de-flocculation of suspended matter in estuaries. Netherlands Journal of Sea Research 20, 183-199.

Fellman, J.B., Hood, E. and Spencer, R.G.M., 2010. Fluorescence spectroscopy opens new windows into dissolved organic matter dynamics in freshwater ecosystems: A review. Limnology and Oceanography 55, 2452-2462.

Flemming, H.-C. and Wingender, J., 2010. The biofilm matrix. Nature Reviews Microbiology 8, 623-633.

Fourqurean, J.W., Escorcia, S.P., Anderson, W.T. and Zieman, J.C., 2005. Spatial and seasonal variability in elemental content, $\delta^{13} \mathrm{C}$, and $\delta^{15} \mathrm{~N}$ of Thalassia testudinum from South Florida and its implications for ecosystem studies. Estuaries 28, 447-461.

Fry, B. and Smith, T.J., 2002. Stable isotope studies of red mangroves and filter feeders from the Shark River estuary, Florida. Bulletin of Marine Science 70, 871-890.

Gonneea, M.E., Paytan, A. and Herrera-Silveira, J.A., 2004. Tracing organic matter sources and carbon burial in mangrove sediments over the past 160 years. Estuarine Coastal and Shelf Science 61, 211-227.

Goñi, M.A., Ruttenberg, K.C. and Eglinton, T.I., 1998.A reassessment of the sources and importance of land-derived organic matter in surface sediments from the Gulf of Mexico. Geochimica et Cosmochimica Acta 62, 3055-3075.

Goñi, M. A., Cathey, M. W., Kim, Y. H., Voulgaris, G., 2005. Fluxes and sources of suspended organic matter in an estuarine turbidity maximum region during low discharge conditions. Estuarine, coastal and shelf science 63, 683-700.

Helms, J. R., Stubbins, A., Ritchie, J. D., Minor, E. C., Kieber, D. J., Mopper, K., 2008. Absorption spectral slopes and slope ratios as indicators of molecular weight, source, and photobleaching of chromophoric dissolved organic matter. Limnology and Oceanography, 53, 955-969.

Harvey, H.R. and Mannino, A., 2001.The chemical composition and cycling of particulate and macromolecular dissolved organic matter in temperate estuaries as revealed by molecular organic tracers. Organic Geochemistry 32, 527-542.

Hayes, J., 1993. Factors controlling ${ }^{13} \mathrm{C}$ contents of sedimentary organic compounds: Principles and evidence. Marine Geology 113, 111-125.

Hedges, J.I., Cowie, G.L., Richey, J.E., Quay, P.D., Benner, R., Strom, M. and Forsberg, B.R., 1994. Origins and processing of organic matter in the Amazon River as indicated by carbohydrates and amino acids. Limnology and oceanography 39, 743-761. 
Hedges, J.I., Ertel, J.R., Quay, P.D., Grootes, P.M., Richey, J.E., Devol, A.H., Farwell, G.W., Schmidt, F.W. and Salati, E., 1986. Organic carbon-14 in the Amazon River system. Science (Washington) 231, 1129-1131.

Hedges, J.I. and Weliky, K.,1989. Diagenesis of conifer needles in a coastal marine environment. Geochimica et Cosmochimica Acta 53, 2659-2673.

Hernes, P.J., Benner, R., Cowie, G.L., Goñi, M.A., Bergamaschi, B.A. and Hedges, J.I., 2001. Tannin diagenesis in mangrove leaves from a tropical estuary: A novel molecular approach. Geochimica et Cosmochimica Acta 65, 3109-3122.

Hernes, P.J. and Hedges, J.I., 2004. Tannin signatures of barks, needles, leaves, cones, and wood at the molecular level. Geochimica et Cosmochimica Acta 68, 1293-1307.

He, D., Mead, R. N., Belicka, L., Pisani, O., Jaffé, R., 2014. Assessing source contributions to particulate organic matter in a subtropical estuary: A biomarker approach. Organic Geochemistry 75, 129-139

Hill, A., James, I., Linden, P., Matthews, J., Prandle, D., Simpson, J., Gmitrowicz, E., Smeed, D., Lwiza, K. and Durazo, R., 1993. Dynamics of tidal mixing fronts in the North Sea [and discussion]. Philosophical Transactions of the Royal Society of London. Series A: Physical and Engineering Sciences 343, 431-446.

Hernandez, M. E., Mead, R., Peralba, M. C., Jaffé, R., 2001. Origin and transport of $<\mathrm{i}>$ $\mathrm{n}</ \mathrm{i}>$-alkane-2-ones in a subtropical estuary: potential biomarkers for seagrass-derived organic matter. Organic Geochemistry 32, 21-32.

Howard, P. J. A., 1965. The carbon-organic matter factor in various soil types. Oikos 15, 229-236.

Jaffé, R., Boyer, J.N., Lu, X., Maie, N., Yang, C., Scully, N.M. and Mock, S., 2004. Source characterization of dissolved organic matter in a subtropical mangrove-dominated estuary by fluorescence analysis. Marine Chemistry 84, 195-210.

Jaffé, R., Mead, R., Hernandez, M.E., Peralba, M.C. and DiGuida, O.A., 2001.Origin and transport of sedimentary organic matter in two subtropical estuaries: a comparative, biomarker-based study. Organic Geochemistry 32, 507-526.

Kirk, J., 1980.Spectral adsorption properties of natural watres: contribtion of the soluble and particulate fractions to light absorption in some inland watres of south-eastern Australia. Marine and Freshwater Research 31, 287-296. 
Li, W.-T., Xu, Z.-X., Li, A.-M., Wu, W., Zhou, Q. and Wang, J.-N., 2013. HPLC/HPSEC-FLD with multi-excitation/emission scan for EEM interpretation and dissolved organic matter analysis. Water Research 47, 1246-1256.

Little, C., 2000. The biology of soft shores and estuaries, Oxford University Press. Larsen, L. G., Harvey, J. W., Noe, G. B., Crimaldi, J. P., 2009. Predicting organic floc transport dynamics in shallow aquatic ecosystems: Insights from the field, the laboratory, and numerical modeling. Water Resources Research, 45.1-13

Markager, S., Stedmon, C. A.,Søndergaard, M. , 2011. Seasonal dynamics and conservative mixing of dissolved organic matter in the temperate eutrophic estuary Horsens Fjord. Estuarine, Coastal and Shelf Science 92, 376-388.

Maie, N., Behrens, A., Knicker, H. and Kögel-Knabner, I., 2003. Changes in the structure and protein binding ability of condensed tannins during decomposition of fresh needles and leaves. Soil Biology and Biochemistry 35, 577-589.

Maie, N., Boyer, J.N., Yang, C. and Jaffé, R., 2006.Spatial, geomorphological, and seasonal variability of CDOM in estuaries of the Florida Coastal Everglades. Hydrobiologia 569, 135-150.

Maie, N., Scully, N.M., Pisani, O. and Jaffé, R., 2007.Composition of a protein-like fluorophore of dissolved organic matter in coastal wetland and estuarine ecosystems. Water Research 41, 563-570.

Maie, N., Pisani, O., Jaffé, R., 2008. Mangrove tannins in aquatic ecosystems: Their fate and possible influence on dissolved organic carbon and nitrogen cycling. Limnology and Oceanography 53, 160-171.

Mayer, L.M., Schick, L.L., Skorko, K. and Boss, E., 2006.Photodissolution of particulate organic matter from sediments. Limnology and Oceanography 51, 1064-1071.

Mueller-Harvey, I.,2001.Analysis of hydrolysable tannins. Animal Feed Science and Technology 91, 3-20.

Maksymowska, D., Richard, P., Piekarek-Jankowska, H., Riera, P., 2000. Chemical and isotopic composition of the organic matter sources in the Gulf of Gdansk (Southern Baltic Sea). Estuarine, Coastal and Shelf Science 51, 585-598.

Neto, R.R., Mead, R.N., Louda, J.W. and Jaffé, R., 2006.Organic biogeochemistry of detrital flocculent material (floc) in a subtropical, coastal wetland. Biogeochemistry 77 , 283-304.

Nguyen, R.T. and Harvey, H.R., 1994.A rapid micro-scale method for the extraction and analysis of protein in marine samples. Marine chemistry 45, 1-14. 
Odum, W.E. and Heald, E.J., Coupling of land and water systems. 1975.129-136, Springer. New York. US

Opsahl, S. and Benner, R., 1999.Characterization of carbohydrates during early diagenesis of five vascular plant tissues. Organic Geochemistry 30, 83-94.

Osburn, C.L., Handsel, L.T., Mikan, M.P., Paerl, H.W. and Montgomery, M.T., 2012. Fluorescence Tracking of Dissolved and Particulate Organic Matter Quality in a RiverDominated Estuary. Environmental Science and Technology 46, 8628-8636.

Ohno, T., 2002. Fluorescence inner-filtering correction for determining the humification index of dissolved organic matter. Environmental Science and Technology 36, 742-746.

Parfitt, R.L. and Newman, R.H., 2000. ${ }^{13}$ C NMR study of pine needle decomposition. Plant and Soil 219, 273-278.

Parsons, T.R. , 1984. Biological oceanographic processes (3rd ed'84).

Peterson, B.J. and Fry, B.,1987.Stable isotopes in ecosystem studies. Annual review of ecology and systematics 18, 293-320.

Pisani, O., Yamashita, Y. and Jaffe, R., 2011. Photo-dissolution of flocculent, detrital material in aquatic environments: Contributions to the dissolved organic matter pool. Water Research 45, 3836-3844.

Pisani, O., Oros, D. R., Oyo-Ita, O. E., Ekpo, B. O., Jaffé, R., Simoneit, B. R. , 2013. Biomarkers in surface sediments from the Cross River and estuary system, SE Nigeria: Assessment of organic matter sources of natural and anthropogenic origins. Applied Geochemistry 31, 239-250.

Porcal, P., Dillon, P.J. and Molot, L.A., 2013.Photochemical production and decomposition of particulate organic carbon in a freshwater stream. Aquatic Sciences 75, 469-482.

Proestos, C., Sereli, D. and Komaitis, M., 2006. Determination of phenolic compounds in aromatic plants by RP-HPLC and GC-MS. Food Chemistry 95, 44-52.

Proffitt, C., Devlin, D. J., 2005. Grazing by the intertidal gastropod Melampus coffeus greatly increases mangrove leaf litter degradation rates. Marine Ecology Progress Series 296, 209-218.

Raymond, P.A. and Bauer, J.E., 2001. Use of (14)C and (13)C natural abundances for evaluating riverine, estuarine, and coastal DOC and POC sources and cycling: a review and synthesis. Organic Geochemistry 32, 469-485. 
Rice, D.L., 1982. The detritus nitrogen problem: new observations and perspectives from organic geochemistry. Mar. Ecology Progress Series 9, 153-162.

Rivera-Monroy, V.H., Twilley, R.R., Davis, S.E., III, Childers, D.L., Simard, M., Chambers, R., Jaffe, R., Boyer, J.N., Rudnick, D.T., Zhang, K., Castaneda-Moya, E., Ewe, S.M.L., Price, R.M., Coronado-Molina, C., Ross, M., Smith, T.J., III, Michot, B., Meselhe, E., Nuttle, W., Troxler, T.G. and Noe, G.B., 2011.The Role of the Everglades Mangrove Ecotone Region (EMER) in Regulating Nutrient Cycling and Wetland Productivity in South Florida. Critical Reviews in Environmental Science and Technology 41, 633-669.

Romigh, M.M., Davis, S.E., III, Rivera-Monroy, V.H. and Twilley, R.R., 2006. Flux of organic carbon in a riverine mangrove wetland in the Florida Coastal Everglades. Hydrobiologia 569, 505-516.

Rumpel, C., Janik, L. J., Skjemstad, J. O., Kögel-Knabner, I.,2001. Quantification of carbon derived from lignite in soils using mid-infrared spectroscopy and partial least squares. Organic Geochemistry 32, 831-839.

Saliot, A., Derieux, S., Sadouni, N., Bouloubassi, I., Fillaux, J., Dagaut, J., Momzikoff, A., Gondry, G., Guillou, C. and Breas, O., 2002.Winter and spring characterization of particulate and dissolved organic matter in the Danube-Black Sea mixing zone. Estuarine, coastal and shelf science 54, 355-367.

Santin, C., Yamashita, Y., Otero, X.L., Alvarez, M.A. and Jaffé, R., 2009.Characterizing humic substances from estuarine soils and sediments by excitation-emission matrix spectroscopy and parallel factor analysis. Biogeochemistry 96, 131-147.

Scully, N.M., Maie, N., Dailey, S.K., Boyer, J.N., Jones, R.D. and Jaffé, R., 2004.Early diagenesis of plant-derived dissolved organic matter along a wetland, mangrove, estuary ecotone. Limnology and Oceanography 49, 1667-1678.

Shank, G.C., Zepp, R.G., Vähätalo, A., Lee, R. and Bartels, E., 2010. Photobleaching kinetics of chromophoric dissolved organic matter derived from mangrove leaf litter and floating Sargassum colonies. Marine Chemistry 119, 162-171.

Slim, F., Heminga, M., Kazungu, J. and Ganssen, G., 1994.Carbon outwelling from a mangrove forest with adjacent seagrass beds and coral reefs (Gazi Bay, Kenya). Marine Ecology Progress Series. 106, 291-301.

Smith III, T., Foster, A., Tiling-Range, G. and Jones, J., 2013.Dynamics of mangrovemarsh ecotones in subtropical coastal wetlands: fire, sea-level rise, and water levels. Fire Ecology 9, 66-77. 
Stedmon, C.A., Markager, S. and Bro, R., 2003.Tracing dissolved organic matter in aquatic environments using a new approach to fluorescence spectroscopy. Marine Chemistry 82, 239-254.

Shimeta, J., Amos, C. L., Beaulieu, S. E., Katz, S. L.,2003. Resuspension of benthic protists at subtidal coastal sites with differing sediment composition. Marine Ecology Progress Series 259, 103-115.

Tenore, K.R., 1977. Growth of Capitella capitata cultured on various levels of detritus derived from different sources. Limnology and Oceanography 22.936-941.

Tremblay, L. and Gagne, J.-P., 2009. Organic matter distribution and reactivity in the waters of a large estuarine system. Marine Chemistry 116, 1-12.

Twilley, R.R., 1985.The exchange of organic carbon in basin mangrove forests in a southwest Florida estuary. Estuarine, Coastal and Shelf Science 20, 543-557.

Tue, N.T., Quy, T.D., Hamaoka, H., Nhuan, M.T., Omori, K., 2012. Sources and exchange of particulate organic matter in an estuarine mangrove ecosystem of Xuan Thuy National Park, Vietnam. Estuaries and Coasts 35, 1060-1068.

Valentine, J.F. and Heck, K.L.,1999.Seagrass herbivory: evidence for the continued grazing of marine grasses. Marine Ecology Progress Series 176, 291-302.

Valiela, I.,1995. Marine ecological processes, Springer.MA, US.

Van Mooy, B.A.S., Keil, R.G. and Devol, A.H., 2002. Impact of suboxia on sinking particulate organic carbon: Enhanced carbon flux and preferential degradation of amino acids via denitrification. Geochimica Et Cosmochimica Acta 66, 457-465.

Volkman, J.K. and Tanoue, E., 2002. Chemical and biological studies of particulate organic matter in the ocean. Journal of Oceanography 58, 265-279.

Vergeer, L.H., Aarts, T.L., De Groot, J.D,. 1995. The "wasting disease" and the effect of abiotic factors (light intensity, temperature, salinity) and infection with Labyrinthula zosterae on the phenolic content of Zostera marina shoots," Aquatic Botany 52,35-44.

Wang, X.C., Druffel, E.R. and Lee, C., 1996.Radiocarbon in organic compound classes in particulate organic matter and sediment in the deep northeast Pacific Ocean.

Geophysical research letters 23, 3583-3586.

West, J. and Sangodoyin, A., 1991.Depth-mean tidal current and sediment concentration relationships in three partially mixed estuaries. Estuarine, Coastal and Shelf Science 32, 141-159. 
Williams, C.J., Jaffé, R., Anderson, W.T. and Jochem, F.J., 2009.Importance of seagrass as a carbon source for heterotrophic bacteria in a subtropical estuary (Florida Bay).

Estuarine Coastal and Shelf Science 85, 507-514.

Yamashita, Y., Scinto, L.J., Maie, N. and Jaffé, R., 2010.Dissolved Organic Matter Characteristics Across a Subtropical Wetland's Landscape: Application of Optical Properties in the Assessment of Environmental Dynamics. Ecosystems 13, 1006-1019.

Yu, Z. and Dahlgren, R.A., 2000. Evaluation of methods for measuring polyphenols in conifer foliage. Journal of Chemical Ecology 26, 2119-2140. 


\section{CHAPTER V}

CHEMICAL CHARACTERIZATION OF PROTEIN-LIKE FLUOROPHORES IN NATURAL ORGANIC MATTER 


\subsection{Abstract}

This study re-evaluates the traditionally defined protein-like fluorophores in natural organic matter by chromatographic measurements. Size exclusion chromatography was used to demonstrate the diversity in molecular weight distribution of the compounds associated with the T-peak (tyrosine-like: Excitation/Emission maximum, 280/325 nm) fluorescence. A chromatographic overlap in the size exclusion trace with tyrosine and gallic acid standards was also observed. The latter is an important constituent of hydrolysable tannins commonly found in senescent plant materials and potentially a significant interference in the actual protein-like fluorescence. Through the use of gas chromatography-mass spectrometry (GC-MS), significant amounts of gallic acid were found in floc samples, particularly at mangrove-dominated sites. An analytical methodology was set up to assess contributions to the protein-like fluorescence from both gallic acid and amino acids in natural samples. The fluorescence quantum yield of both tyrosine and gallic acid were compared and combined with the quantitative measurements of these two components, the strengths of each compound in the emission of protein-like fluorescence was assessed. Results suggest the optically defined proteinlike fluorophores feature heterogeneous composition as composed of both proteinaceous materials and phenolic moieties in humic-like substances. The latter could contribute more significantly to natural OM samples than the actual amino acids 


\subsection{Introduction}

The chemical composition of natural organic matter $(\mathrm{OM})$ is complex. In the last decades, UV absorption and fluorescence emission measurements have been used extensively for natural OM characterization (Fellman et al., 2010; Jaffé et al., 2014). In particular, excitation emission matrix fluorescence combined with parallel factor analysis (EEM-PARAFAC) has been widely used to define fluorescence components in natural OM (Stedmon and Bro, 2008; Fellman et al., 2010; Osburn et al., 2012). However, some concerns on the uncertainty and limitation of EEM-PARAC to characterize OM sources and composition has been voiced (Ishii and Boyer, 2012; Yang and Hur, 2014). EEMs for dissolved organic matter (DOM) characterization are commonly evaluated by visual inspections (Coble, 1996; 2007), which are not chemically defined and also not applicable for quantitative studies. Thus they are often coupled with multivariate data analysis, where PARAFAC is the most commonly used statistical tool. PARAFAC can identify the individual fluorophores present in the simple mixture (Bro 1997), however, it does not resolve compounds that showed similar fluorescent phenomena, particularly in complex mixture like DOM (Del Vecchio and Blough 2004). In many earlier studies, three general types of fluorescence peaks have been identified in the natural water: humic-like, protein-like, and pigment-like fluorescence (Coble et al., 1993; Coble 1996; Mopper and Schultz 1993). Fluorescence characterization of humic-like DOM has been the focus since the pioneering work of Kalle (1949). However, not many studies have characterized the chemical composition of protein-like fluorophores, which are generally considered to be derived from amino acid containing materials (Yamashita and Taonue, 2003). Protein-like fluorescence in DOM is considered ubiquitous in aquatic ecosystems 
(Wu and Tanoue, 2001) and has been suggested to comprise a major portion of the dissolved organic nitrogen (DON) pool (Bushaw et al., 1996). Optically, protein-like components were assigned to fluorophores with emission wavelength of around $300 \mathrm{~nm}$ (tyrosine-like) and $350 \mathrm{~nm}$ (tryptophan-like). Many studies have used fluorescence spectroscopy to detect proteinaceous materials in CDOM, which was successfully applied for oceanic DOM (Coble 1996; McCarthy et al., 1998; Yamashita and Tanoue 2004; Maie et al, 2006). However, in coastal /estuarine ecosystem, the nature of protein-like fluorescence components may be heterogeneous as it can also contain some of the nonprotein substances that feature similar fluorescence, such as polyphenols (Maie et al., 2007). Many other compounds can overlap the protein-like fluorophores (T-peak; Ex/Em at $180 / 325 \mathrm{~nm}$ ), and thus cannot be resolved through fluorescence spectroscopy (Mayer et al., 1999; Reynolds, 2003). However, not much is known about the contribution of non-protein fluorophores to the protein-like fluorescence (Maie et al., 2007).

Polyphenolic compounds are commonly found in natural organic matter. The lignin monomer (propylphenol) and tannin monomer (gallic acid) showed fluorescence in the same region of tyrosine and tryptophan (Hernes et al., 2009). Structurally, phenolic compounds, tyrosine and tryptophan all have an aromatic ring, which absorbs in the UV region greater than aliphatic structures (Weishaar et al., 2003) and exhibit similar fluorescence properties. Tannins can comprises as much as $20 \%$ by weight of leaf (Benner et al.,1990), needle (Hedges and Weliky,1989), and bark tissues (Kelsey and Hannon,1989), and are second in abundance only to carbohydrates in senescent yellow mangrove leaf material entering the estuarine system (Hernes et al., 2001). Compared with lignin phenols, tannins are mostly soluble and commonly found in the DOM pool 
(Maie et al., 2008), water extractable portion of mangrove surface sediment (Zuloaga et al., 2013), and coastal sediments (Bao et al., 2013). However, tannins have the tendency to interact with proteins to form insoluble precipitates (Maie et al., 2008). In some coastal regions, a large portion of POM was found to be extractable tannins, in which phenolic acids were derived almost entirely from mangrove litter (Alongi 1987; Boto et al., 1989). Our previous study on the POM composition in a fringe mangrove estuary observed intense tyrosine-like fluorescence in the base extract of particulate organic matter (POM) (see Chapter 4), for POM likely derived from mangrove detritus. Preliminary analyses detected the free form of gallic acid in such POM extract, which could be derived from tannins and contribute to the intense protein-like fluorescence signal (see details presented in section 5.3.1). There are two types of tannins in vascular plants, condensed tannins and hydrolysable tannins (Fig.5.1; Hernes and Hedges 2000). The phenol monomers that constitute the building blocks of the condensed and hydrolysable tannins are different. Hydrolyzable tannins are primarily made up of gallic acid and are classified into different classes of gallotannin. The various types of gallotannin (or tannin) can yield gallic acid and glucose with different ratios through hydrolysis (Haslam, 1966). In contrast, the condensed tannins exist as oligomers and polymers of three-ring flavenols (Hernes and Hedges, 2000).

Tannins, and consequently gallic acid, are a major potential interference in protein-like fluorophors in OM (Maie et al., 2007). This family of polyphenols may contribute significantly to both particulate and dissolved OM exported from mangrove swamps (Maie et al., 2008). Moreover, mangrove tannins specifically, have been shown to interact with proteins to form POM, and may become re-dissolved through exposure to 
light (Maie et al., 2008). Undoubtedly, it is very important to determine the contribution of these polyphenols to the traditionally defined protein-like fluorescence. Since fluorescence measurements are not compound specific, many studies have linked fluorescence data with chemical composition obtained by other techniques (e.g. Pautler et al., 2012). Therefore, in order to precisely assign protein-like fluorescence to source material and quantify the contribution from protein and phenolic compounds, characterization of the chemical constituents of protein-like fluorescence is needed.

A number of analytical methods have been proposed for the determination of lignin and tannin derived compounds. Multiple techniques have been used such as HPLC, NMR, MALDI-TOF/MS, and GC-MS for the analysis of hydrolysable tannins (Proestos and Komaitis, 2006; Lobbes et al., 1999; Maie et al., 2003; Hernes and Hedges, 2000). GC-MS measurement of gallic acid is highly specific, simple to analyze, and have low interferences from other phenolic compounds (Yoshida et al., 1989). In the present study, I compared the concentration, fluorescence intensity, and fluorescence yield efficiency of phenolic acid vs. amino acid in order to gain a better idea of the strengths of these constituents in the protein-like fluorophores. We developed an analytical method using GC-MS based on tannin hydrolysis (Tor et al., 1996), protein hydrolysis (Keil and Kirchman, 1991;Yamashita and Tanoue, 2003; Jaffé et al., 2012) followed by different derivatization methods for gallic acid analysis (Tor et al.,1996; An et al.,2013) and tyrosine analysis (Macko et al.,1997). This is a preliminary study on the chemical characterization of OM fluorophores, but through which we want to raise attention on the need for a critical evaluation of the traditionally defined EEM-PARAFAC components. 


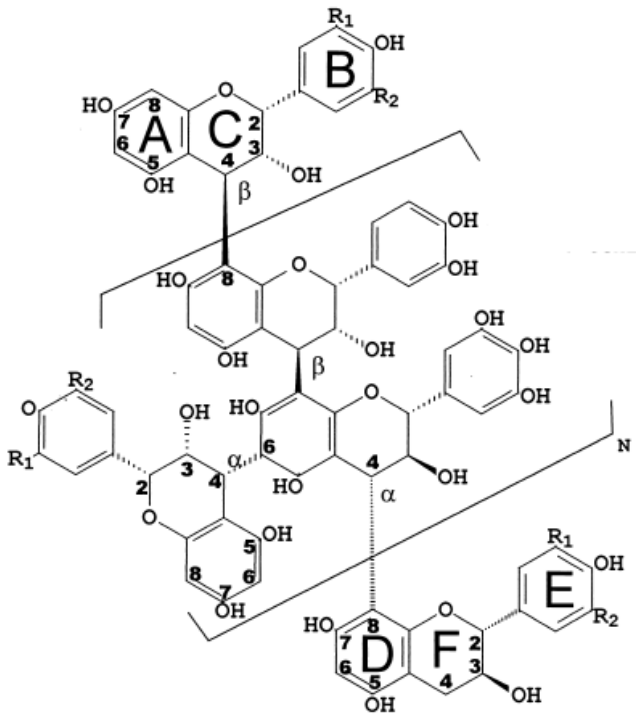

Condensed Tannins

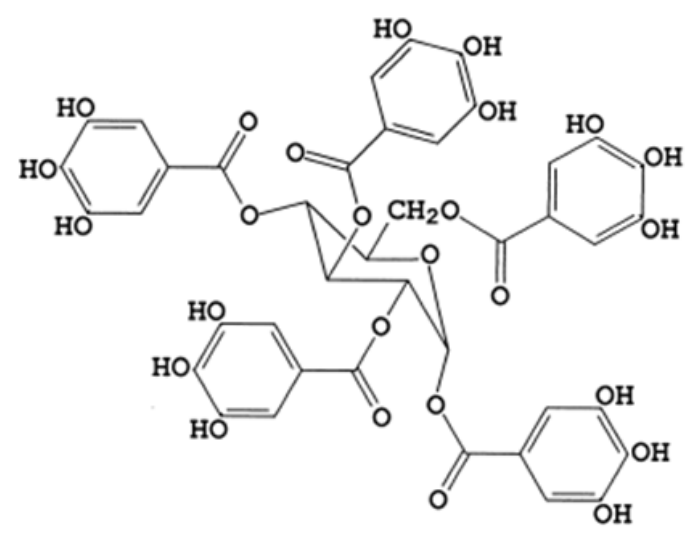

Hydrolyzable Tannins

Figure 5.1 Structure of typical condensed and hydrolysable tannins (Hernes and Hedges 2000).

\subsection{Materials and Methods}

Gallic acid monohydrate standard (ACS reagent, $\geq 98.0 \%$ ) was purchased from Sigma-Aldrich Co. (St. Louis, MO). L-Tyrosine standard was purchased from Pierce Chemical Inc. (Rockford, IL). Working solutions of gallic acid were prepared in methanol. Amino acid standard was prepared by dissolving crystalline amino acid in distilled $0.1 \mathrm{~N} \mathrm{HCl}$ and stored at $4^{0} \mathrm{C}$. The protein standard, bovine serum albumin (BSA) was purchased from Sigma-Aldrich Co. and stored in freezer until analysis. The derivatization agent BSTFA (98 to 100\% N,O-bis[Trimethylsilyl]trifluoroacetamide), was purchased from Fisher Scientific Inc. 2-Propanol (isopropanol; HPLC grade, Fisher Scientific, Fairlawn, NJ) was acidified to $2.8 \mathrm{M}$ by the addition of $250 \mu \mathrm{L}$ (per milliliter 
of IP) of acetyl chloride (99+\%, Aldrich, Milwaukee, WI). Trifluoroacetic anhydride (TFAA, 99+\%, Pierce Chemical Co., Rockford, IL) was used without further purification. In order to analyze the gallic acid in natural organic matter, flocculent materials (floc), as assemblages of POM, were used. Detailed sampling information of these floc samples can be found in Pisani et al. (2011). Briefly, floc samples were collected at a freshwater site (SRS2) and estuarine mangrove site (SRS6) both for the long-term monitoring sites of the on-going Florida Coastal Everglades-Long Term Ecological Research program (FCE-LTER; http://fcelter.fiu.edu/data/). Floc samples were extracted with $\mathrm{NaOH}(0.1 \mathrm{M})$ as solvent for 24 hours (Santin et al., 2009) and neutralized using $\mathrm{HCl}$ $(25 \% \mathrm{v} / \mathrm{v})$ for optical and chromatographic measurements. Floc extracts were freeze dried at $-50^{\circ} \mathrm{C}$ prior to HPLC analysis. Surface sediments were collected at SRS6 and stored in combusted glass jars (Ichem) in the freezer prior to analysis. Mangrove tannins were obtained from Maie as reported in Maie et al. (2008).

\subsubsection{High Performance Liquid Chromatography with Size Exclusion (HPLC-SEC) analysis on the base extract of floc samples}

The molecular weight distribution of floc base extract was determined by SEC (Maie et al., 2003; Scully et al., 2004) on a high performance liquid chromatography system coupled with a diode array detector (UV-Vis: $280 \mathrm{~nm}$ ) and a fluorometric detector (EX/Em:280/325 nm) in tandem (Surveyor, Thermo Scientific). A YMC-Pack Diol-120 column (pore size $12 \mathrm{~nm}$, I.D. $8.0 \mathrm{~mm} \times$ length $500 \mathrm{~mm}$; YMC Inc) was used. The void volume $\left(\mathrm{V}_{0}=12.6 \mathrm{~min}\right)$ and void volume plus inner volume $\left(\mathrm{V}_{0}+\mathrm{V}_{\mathrm{i}} ; 32.3 \mathrm{~min}\right)$ were determined using Blue Dextran 2000 and L-tyrosine (Pharmacia, Uppsala) respectively. 


\subsubsection{Gallic acid analysis from hydrolysable tannins}

A flow diagram of the overall method is presented in Fig.5.2. The details are as follows:
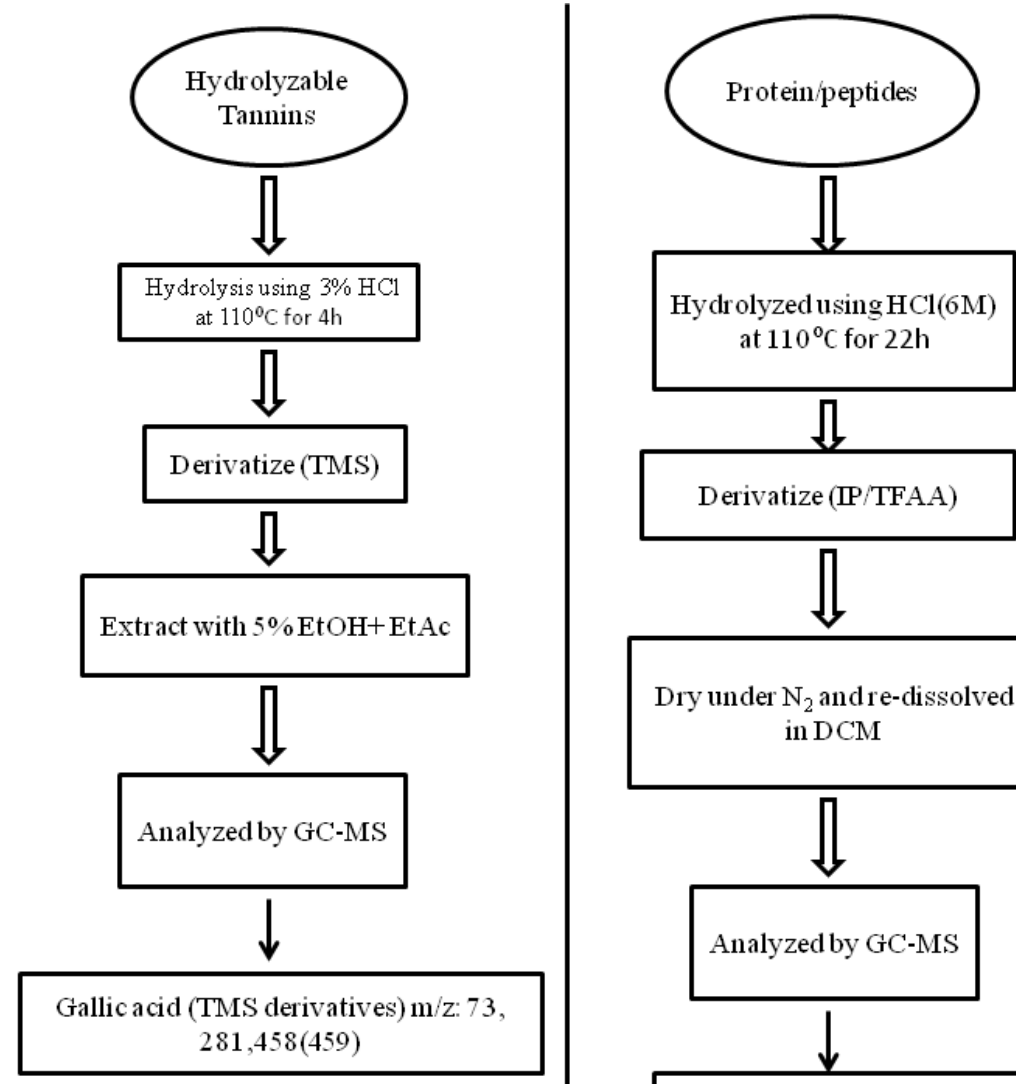

Hydrolyzed using $\mathrm{HCl}(6 \mathrm{M})$ at $110^{\circ} \mathrm{C}$ for $22 \mathrm{~h}$
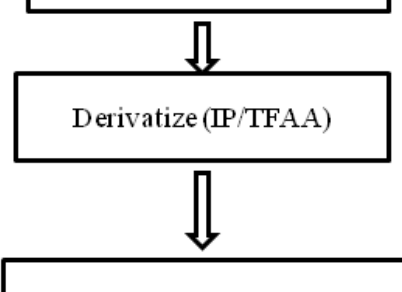

Dry under $\mathrm{N}_{2}$ and re-dissolved in DCM

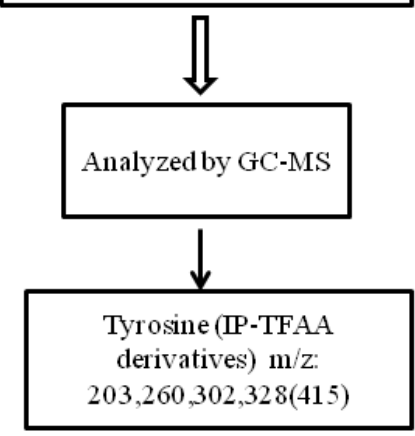

Figure 5.2 Analytical flow chart of gallic acid and tyrosine released from the gallotannin and proteins, respectively.

(a) Hydrolysis

Floc samples $(5-6 \mathrm{mg})$ were mixed with $3 \% \mathrm{HCl}(\mathrm{v} / \mathrm{v})(1 \mathrm{~g}$ per $1 \mathrm{ml} \mathrm{HCl})$ in a $15 \mathrm{~mL}$, screw-cap hydrolysis glass tube (Chemglass Inc.) and vortexed for 10s. Air in the tube was replaced by bubbling nitrogen through the solution for $30 \mathrm{~min}$. The hydrolysis 
tube was capped immediately and placed in a metal test tube cage in an oven. Samples were hydrolyzed at $110^{\circ} \mathrm{C}$ for $4 \mathrm{~h}$. Gallic acid standards were prepared in the same way for recovery assessment.

(b) Extraction

After hydrolysis, the tubes were removed from the oven and cooled for $30 \mathrm{~min}$ then $15 \mathrm{~mL}$ of $5 \% \mathrm{EtOH}+$ EtAc were added to the acid solution three consecutive times ( $5 \mathrm{ml}$ each time) to extract the gallic acid. was Next, $25 \mathrm{~g}$ of sodium sulfate was added to each of the hydrolyzed samples to remove the aqueous remains. The mixed solution was then filtered, quantitatively transferred into $25 \mathrm{ml}$ volumetric flask, and then filled with $5 \%$ EtOH+EtAc to the calibration mark. Finally, $2 \mathrm{~mL}$ of the extract was pipetted into glass vessel for derivatization and dried under $\mathrm{N}_{2}$.

(c) Derivatization

As reported in Benner et al. (1990), gallic acid is best analyzed as a trimethyl silyl(TMS) derivative by GC-MS. After adding $60 \mu \mathrm{L}$ reagent $(1 \mathrm{ml}$ BSTFA with $\sim 333 \mu \mathrm{L}$ pyridine) to the samples and heating at $45^{\circ} \mathrm{C}$ for $30 \mathrm{~min}$, derivatizing agents were dried under $\mathrm{N}_{2}$ and samples were redissolved in $150 \mu \mathrm{L}$ DCM.

(d) GC-MS determination of gallic acid Analytical standards of TMS derivatives of gallic acid at concentrations ranging from 0.2 to $10 \mu \mathrm{g} \mathrm{mL}^{-1}$ were injected into the GC-MS system. The GC/MS analyses were performed on a Hewlett-Packard 6890 GC linked to a HP 5973 MS system, and fitted with Rtx-5MS columns (30 meters long, $0.25 \mathrm{~mm}$ ID, $0.25 \mathrm{um}$ df) from RESTEK, USA. The GC oven temperature was programmed as follows: $60^{\circ} \mathrm{C}$ (held $1 \mathrm{~min}$ ), increase to 
$300{ }^{\circ} \mathrm{C}$ at ramp rate of $6{ }^{\circ} \mathrm{C} / \mathrm{min}$, then held at $300^{\circ} \mathrm{C}$ for $60 \mathrm{~min}$. Identification of gallic acid was performed by comparing with NIST library and also with gallic acid standard.

\subsubsection{Tyrosine analysis}

\section{a. Hydrolysis}

Acid hydrolysis for analysis of amino acid (tyrosine) was performed according to Yamashita and Tanoue (2003) with some modification as reported by Jaffé et al. (2012). Briefly, a protein standard (bovine serum albumin, BSA) $(\sim 5 \mathrm{mg})$ was weighed into the same $15 \mathrm{ml}$ combusted hydrolysis tubes as for the gallic acid analysis and mixed with 5 $\mathrm{mL} 6 \mathrm{M} \mathrm{HCl}$. Then $100 \mu \mathrm{L}$ of ascorbic acid $(6 \mathrm{mM})$ was added as anti-oxidant. The hydrolysis tube were flushed with nitrogen for $30 \mathrm{~min}$ to get rid of the dissolved oxygen, filled to headspace with $\mathrm{N}_{2}$, capped with Teflon-lined cap, and placed in an oven at 110 ${ }^{\circ} \mathrm{C}$. After $22 \mathrm{~h}$, the hydrolysis was terminated on ice. The hydrolysate was evaporated to dryness under a stream of $\mathrm{N}_{2}$.

b. Derivatization

Two types of derivatization method has been tested prior to GC-MS analysis on tyrosine:

\section{i. BSTFA derivatization}

To provide a simple one-step derivatization procedure for tyrosine, N,OBis(trimethylsilyl)trifluoroacetamide (BSTFA) derivatization has been used for both tyrosine standard and hydrolyzed protein standard:

Volumes of $100 \mathrm{~mL}$ of BSTFA and $100 \mathrm{~mL}$ of acetonitrile were added to the amino acid standard and free amino acid obtained from acid hydrolysis, which was then 
heated for $30 \mathrm{~min}$ at $100{ }^{\circ} \mathrm{C}$. A pipette was used to transfer $150 \mathrm{~mL}$ of each sample to a glass vial with plastic insert before placing the sample vials in the autosampler carousel to await injection.

ii. Isopropanol- Trifluoroacetic anhydride (IP-TFAA) derivatization This amino acid derivatization method was originally used for stable nitrogen isotope analysis of amino acid by Macko et al., (1997) and then applied for amino acid analysis in DOM samples (Yamashita and Tanoue 2003; Jaffé et al., 2012). Two-hundred microliter aliquots of a $0.05 \mathrm{M}$ solution of each amino acid $(50 \mu \mathrm{mol})$ were placed in a 3 $\mathrm{ml}$ screw-cap vial and evaporated to dryness at $40{ }^{\circ} \mathrm{C}$ under a stream of $\mathrm{N}_{2}$. Next, $0.5 \mathrm{~mL}$ of acidified isopropanol (IP) was added to each sample vial. The vials were sealed with teflon-lined caps and heated at $100{ }^{\circ} \mathrm{C}$ for $1 \mathrm{~h}$. The reaction was quenched by placing the vials in a freezer at $-5{ }^{\circ} \mathrm{C}$. The residual IP was removed under a gentle stream of $\mathrm{N}_{2}$. To remove excess water and IP, $0.25 \mathrm{~mL}$ of distilled $\mathrm{CH}_{2} \mathrm{Cl}_{2}$ was added to each vial in two successive aliquots, each of which was evaporated under a gentle stream of $\mathrm{N}_{2}$ at room temperature. The resultant amino acid esters were acylated by the addition of $0.5 \mathrm{~mL}$ of TFAA and $0.5 \mathrm{~mL}$ of distilled $\mathrm{CH}_{2} \mathrm{Cl}_{2}$. The vials were sealed and heated at $100^{\circ} \mathrm{C}$ for 10 min. The vials were then placed in an ice bath, where the excess TFAA and $\mathrm{CH}_{2} \mathrm{Cl}_{2}$ were removed under a gentle stream of $\mathrm{N}_{2}$. To remove residual TFAA and $\mathrm{CH}_{2} \mathrm{Cl}_{2}, 0.25 \mathrm{~mL}$ of distilled $\mathrm{CH}_{2} \mathrm{Cl}_{2}$ was added to each vial, and this was again removed at $100^{\circ} \mathrm{C}$ under a gentle nitrogen stream. 
c. GC-MS determination on amino acids

The derivatized amino acid trifluoroacetyl-isopropyl esters were analyzed on the same GC-MS system as described above. The following oven temperature program was used: initial temperature was held isothermally at $40{ }^{\circ} \mathrm{C}(1 \mathrm{~min})$, then increased to $70{ }^{\circ} \mathrm{C}$ at a rate of $10{ }^{\circ} \mathrm{C} \min ^{-1}$, then to $170{ }^{\circ} \mathrm{C}(10 \mathrm{~min})$ at a rate of $2{ }^{\circ} \mathrm{C} \min ^{-1}$, then to $250{ }^{\circ} \mathrm{C}$ $(10 \mathrm{~min})$ at a rate of $15^{\circ} \mathrm{C} \mathrm{min}^{-1}$. Mass spectra were recorded under electron impact ionization conditions $(70 \mathrm{eV})$.

\subsection{Results and Discussion}

\subsubsection{Preliminary finding on free form gallic acid in flocculent samples}

This section (5.3.1) is the extension of chapter 4 , which is based on the preliminary study I performed on the composition of POM and floc samples in Everglades' estuaries. For different forms of OM samples, EEM-PARAFAC results were summarized in Table 5.1. Fluorescence measurements showed enriched protein-like components in POM and DOM samples collected in Florida Bay (seagrass dominated estuary) (Table 5.1). Previous reports have linked the protein-like DOM components with seagrass exudation (Maie et al., 2012; see also Chapter 2). For fringe mangrove estuaries of Shark River Slough, mangrove and seagrass detritus are presumably important sources of POM at the lower estuary (Chapter 4). As such, plant detritus could potentially contribute polyphenols (i.e. tannins) resulting in an overestimation of amino acids based on the protein-like fluorescence signal. The neutralized base extract of POM contained intense T fluorophore (Fig. 4.4c), which could therefore be the result of a mixture of proteinaceous material and phenolic moieties derived from senescent plant materials 
(Maie et al., 2007; Hernes et al., 2004). EEMs of gallic acid and tannic acid standards were shown in Fig. 5.3 (Ex: 275 nm; Em: 335 nm).

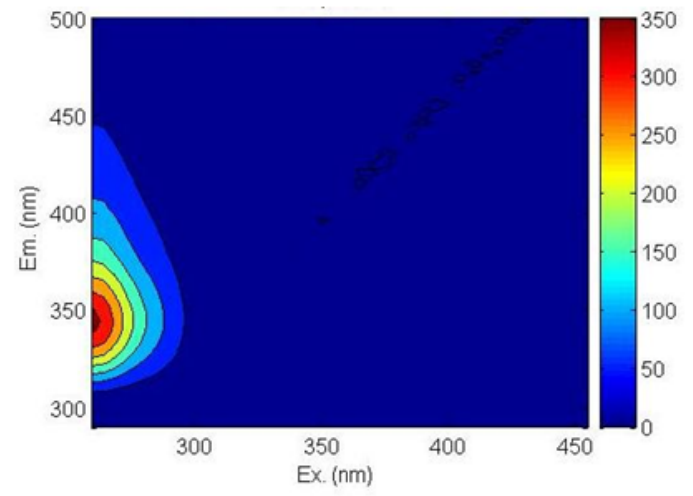

Gallic acid

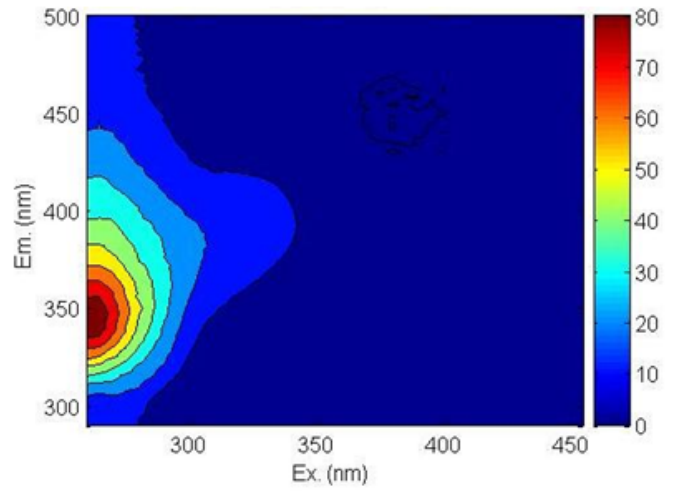

Tannic acid

Figure 5.3 EEMs of gallic acid and tannic acid standard (Ex $280 \mathrm{~nm}$, Em $325 \mathrm{~nm}$ )

Since the MW of proteinaceous materials might be different from other materials such as tannins, producing the protein-like peak (T-peak: Ex $280 \mathrm{~nm}$; Em $325 \mathrm{~nm}$ )(Maie et al., 2003; Hernes and Hedges, 2004; Scully et al., 2004; Jones et al., 2006), I applied SEC to determine the distribution of the protein-like fluorescence along the molecular weight continuum (Fig. 5.4). Here the excitation at $280 \mathrm{~nm}$ and emission at $326 \mathrm{~nm}$ were selected for the detection of protein-like fluorophores. Multiple peaks were resolved on the SEC chromatogram (Fig. 5.4), indicating that compounds with different molecular weight emit protein-like fluorescence. Similar to previous reports (Maie et al., 2007), the SEC chromatogram of mangrove floc extract showed separate peaks (Fig. 5.4, T1 and T2) with retention times corresponding gallic acid and amino acid standards, respectively. While the coincidence of the observed peaks in the floc sample and the standards does not confirm the identity of the peaks under discussion, it suggests that it is quite likely that a significant portion of the protein-like fluorescence might be due to 
gallic acid (and associated tannins) in addition to the amino acids. Tannins are likely to accumulate in floc after decomposition of mangrove leaves (Maie et al., 2008) and contribute to the POM pool. with the similarity of the gallic acid standard (25.32 min) and the T1 peak (25.18 min) elution times on the SEC suggest that a class of components with similar molecular weight to tannin monomers might be produced naturally through the decomposition of hydrolysable tannins (Mueller-Harvey, 2001). 
Table 5.1 Organic C content, PARAFAC composition of OM samples collected at different sites of Everglades

\begin{tabular}{|c|c|c|c|c|c|}
\hline Sample type & Sample sites & Organic $\mathrm{C}$ content & $\begin{array}{c}\text { Terrestrial } \\
\text { humic-like }(\%)\end{array}$ & $\begin{array}{c}\text { Microbial } \\
\text { humic-like (\%) }\end{array}$ & $\begin{array}{c}\text { Protein-like } \\
(\%)\end{array}$ \\
\hline POM & mangrove estuary & $27 \pm 2 \%$ & 40 to 59 & 10 to 17 & 25 to 46 \\
\hline \multirow{2}{*}{ Flocculent } & mangrove site & $13 \%$ & 73 & 11 & 16 \\
\hline & freshwater marsh & $31 \%$ & 71 & 11 & 18 \\
\hline Sediment & mangrove estuary & $15 \%$ & 84 & 9 & 7 \\
\hline UDOM & Florida Bay & 4.01 to $10.69 \mathrm{mg} . \mathrm{L}^{-1}$ & 52 to 71 & 14 to 17 & 29 to 48 \\
\hline
\end{tabular}


Protein distributions from SCE analyses are more variable (Li et al., 2013) and can reflect a broad range of molecular weights with both high MW (macromolecular proteins) and low MW (small peptides and/or amino acids) compounds being represented. Therefore, T2 peak at retention time 29.90 min could possibly represent group of small amino-acid/peptide, which is similar to the tyrosine standard (eluted at $29.50 \mathrm{~min})$. The SEC results revealed that the origin of protein-like fluorescence in POM extracts may be the result of a heterogeneous composition not only based on the presence of amino acids. However, HPLC results did not confirm the identity of these compounds.

Therefore, in order to prove mangrove-derived tannins as a potential component of protein-like fluorescence, GC-MS was used for determining the presence of gallic-acid (free form) in mangrove floc and freshwater marsh floc base-extract. Indeed Gallic acid (TMS derivatized form) was identified in freshwater marsh and mangrove floc samples (Fig.5.5). This could be confirmed by comparison with an autenthic gallic acid standard and reported mass spectral fragmentation patterns (Proestos et al., 2006). 


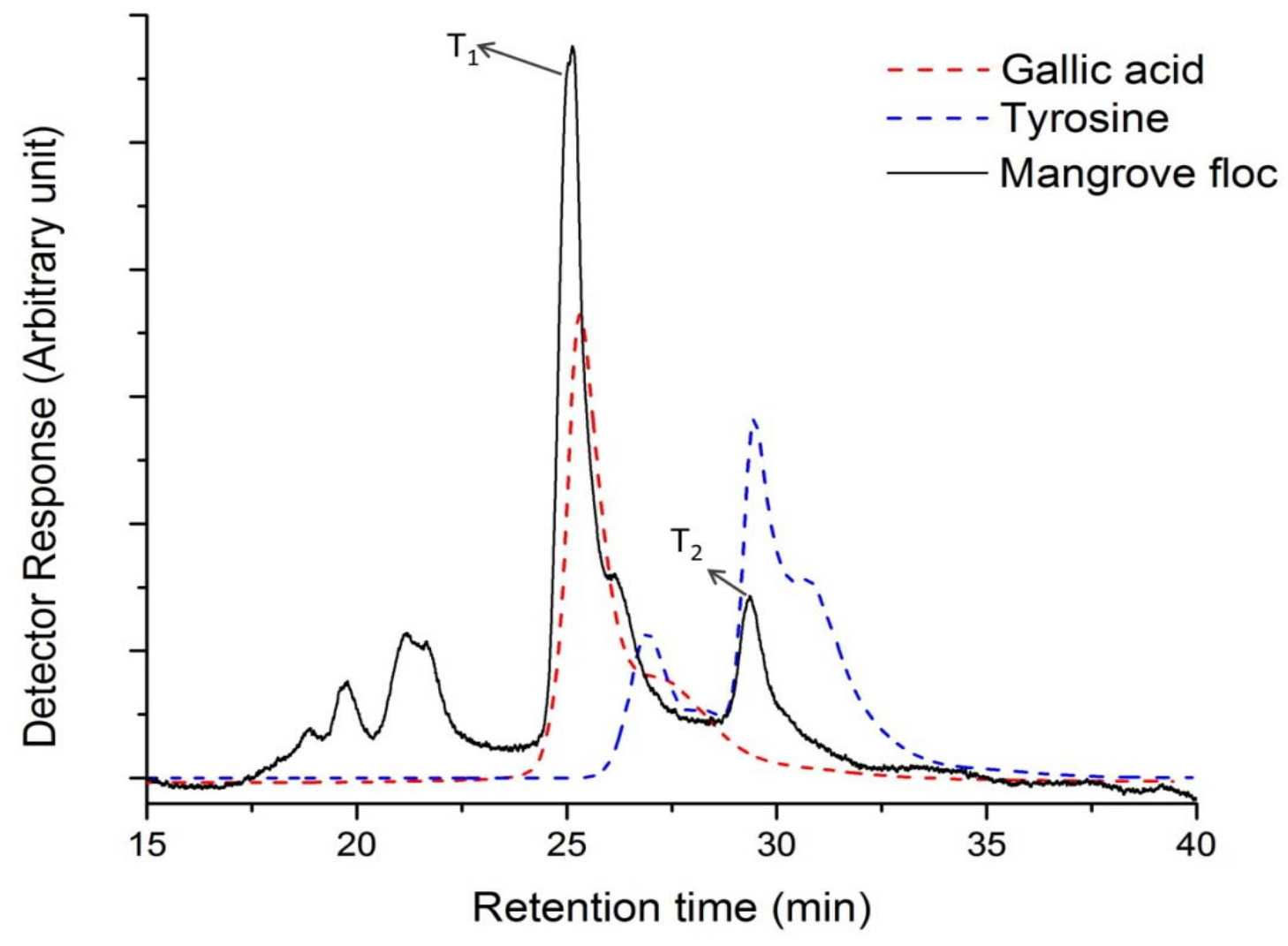

Figure 5.4 SEC-based T-fluorophore distribution for a mangrove floc sample and gallic acid and tyrosine standards. 
a)

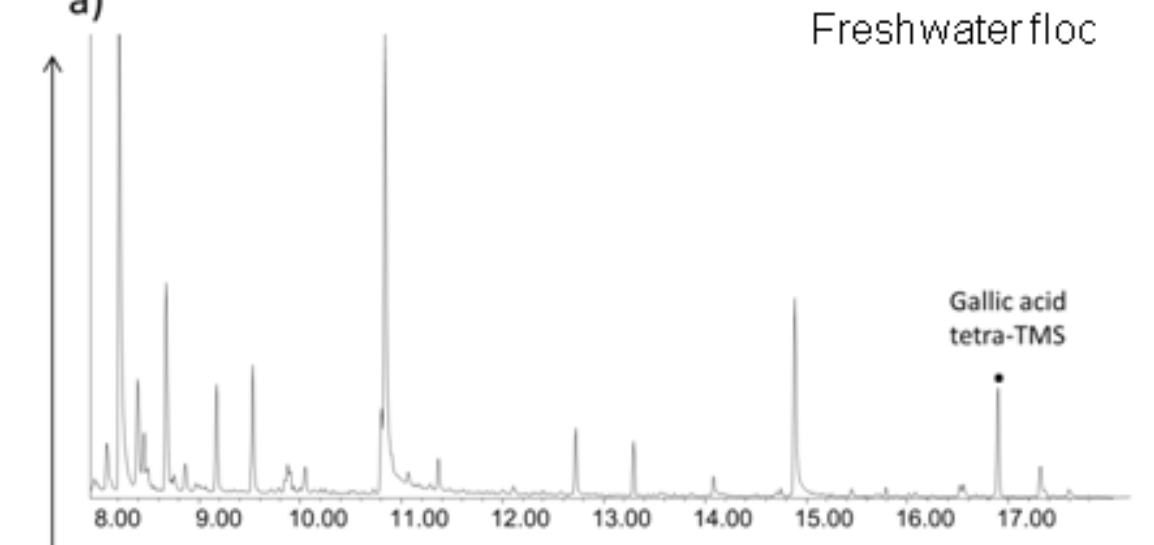

b)

Mangrove floc

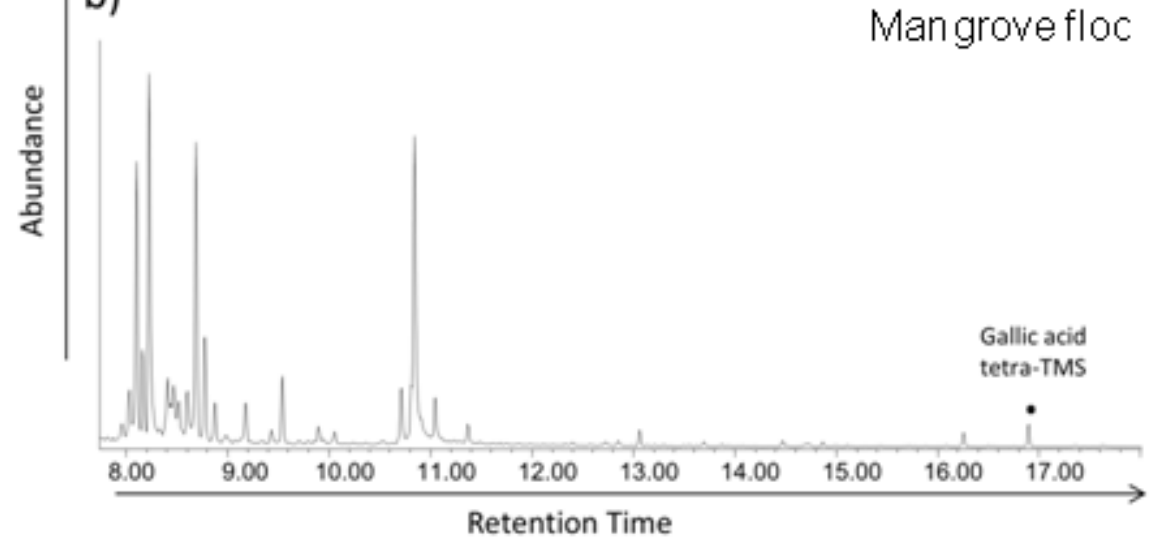

c)

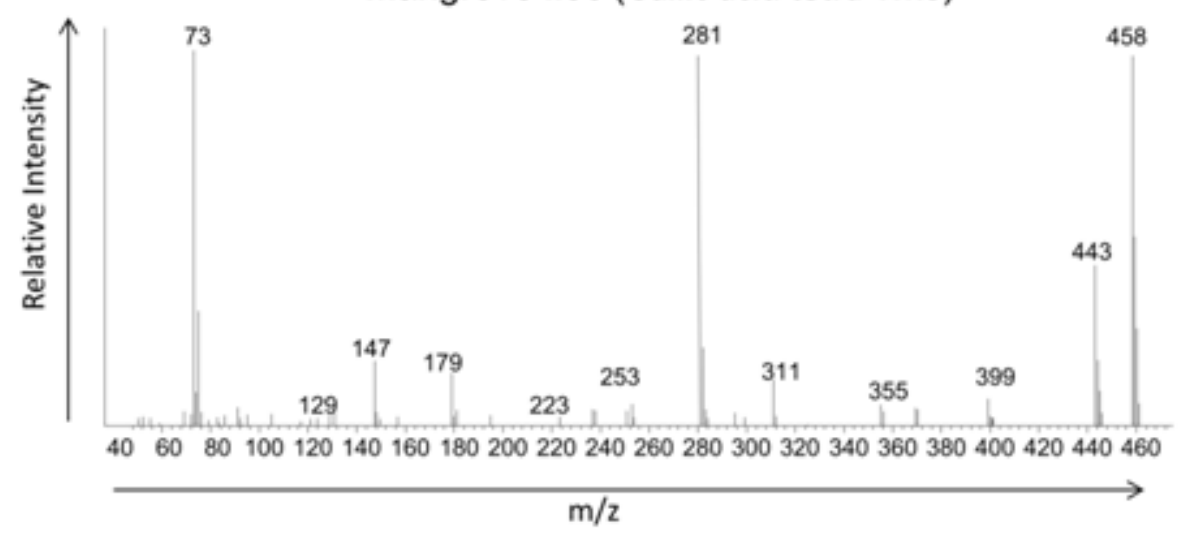

Figure 5.5 The mass spectrum shows the molecular weight of gallic acid's TMS derivative as 458 , and the major characteristic fragmentation ions. 


\subsubsection{Comparison of the fluorescence quantum yield of gallic acid and tyrosine standard}

The wavelength-dependent fluorescence quantum yields were determined for both tyrosine and gallic acid standard. This is needed to calculate the contribution from each compound to the total protein-like fluorescence based on determined concentrations for both analytes. The excitation wavelength was selected as $280 \mathrm{~nm}$ although a previous report has suggested an underestimated quantum yield of quinine sulfate standard for wavelength $<330 \mathrm{~nm}$ (Green and Blough, 1994). However, our UV absorption and fluorescence spectra suggested a higher absorption coefficient at $280 \mathrm{~nm}$ (Fig.5.6) and the comparisons between two standards did not affected the selection of wavelength as long as the quantum yield of both compounds were calculated based on the same excitation wavelength. Thus, the fluorescence intensity was integrated over an emission wavelength range of 212 to $620 \mathrm{~nm}$ at excitation of $280 \mathrm{~nm}$ (Fig.5.6). At the same concentration level, tyrosine exhibited a significantly higher fluorescence intensity and UV absorption at $280 \mathrm{~nm}$ compared with gallic acid. For quantitative analysis, fluorescence per unit absorption (the quantum yield) is needed to assess the contribution of each compound to the bulk protein-like fluorescence. Thus, the quantum yields (Ø) were calculated with a quinine sulfate reference $\left[\mathrm{a}(280)=0.42 \mathrm{~cm}^{-1} ; \varnothing(280)=0.56\right]$. The equation for the quantum yield calculation is shown as below:

$$
\varnothing(280)=\left[\mathrm{F}^{\prime}(280) \cdot \mathrm{a}_{\mathrm{r}} \varnothing_{\mathrm{r}}\right] /\left[\mathrm{a}(280) \cdot \mathrm{F}_{\mathrm{r}} \mathrm{r}\right](\text { Green and Blough, 1994) }
$$

Subscript $r$ refers to the reference, $F^{\prime}$ is the integrated corrected fluorescence emission produced by excitation at $280 \mathrm{~nm}$. 
For both gallic acid and tyrosine standards examined, fluorescence efficiency varies with emission wavelength (Chen 1967; Green and Blough 1994) and concentration (Table.5.2). There are many other factors that could affect the quantum yield, such as $\mathrm{pH}$ (White 1959), photo irradiation (Abdala-Diaz et al., 2006), and substituents on the fluorescence of phenolic compounds (Cowgil, 1963), etc. For the same set of concentration series of both standards, peak fluorescence of gallic acid is around $20 \%$ of tyrosine at the lower concentration range and $10 \%$ at higher concentration (Fig.5.7). For gallic acid, the quantum yield decreased as concentration increased from $1 \mathrm{ppm}$ to 10 ppm. Similarly, tyrosine showed lower quantum yield at high concentration (10 ppm) compared with low concentration (1 ppm) (Table 5.2). The decrease in the fluorescence efficiency (Ø) with the increasing concentration of the solute is due to the quenching of excited molecules by unexcited ones (self-quenching) (Melhuish 1961). Overall, gallic acid showed lower fluorescence efficiency (Ø) compared with tyrosine (Table.5.2) over the concentration range of 1-10 ppm. Based on the quantum yield, we speculated that with same amount of fluorescence intensity emitted by both compounds, quantitatively, gallic acid content should exceed tyrosine when the same amount of bulk fluorescence emission is observed. 

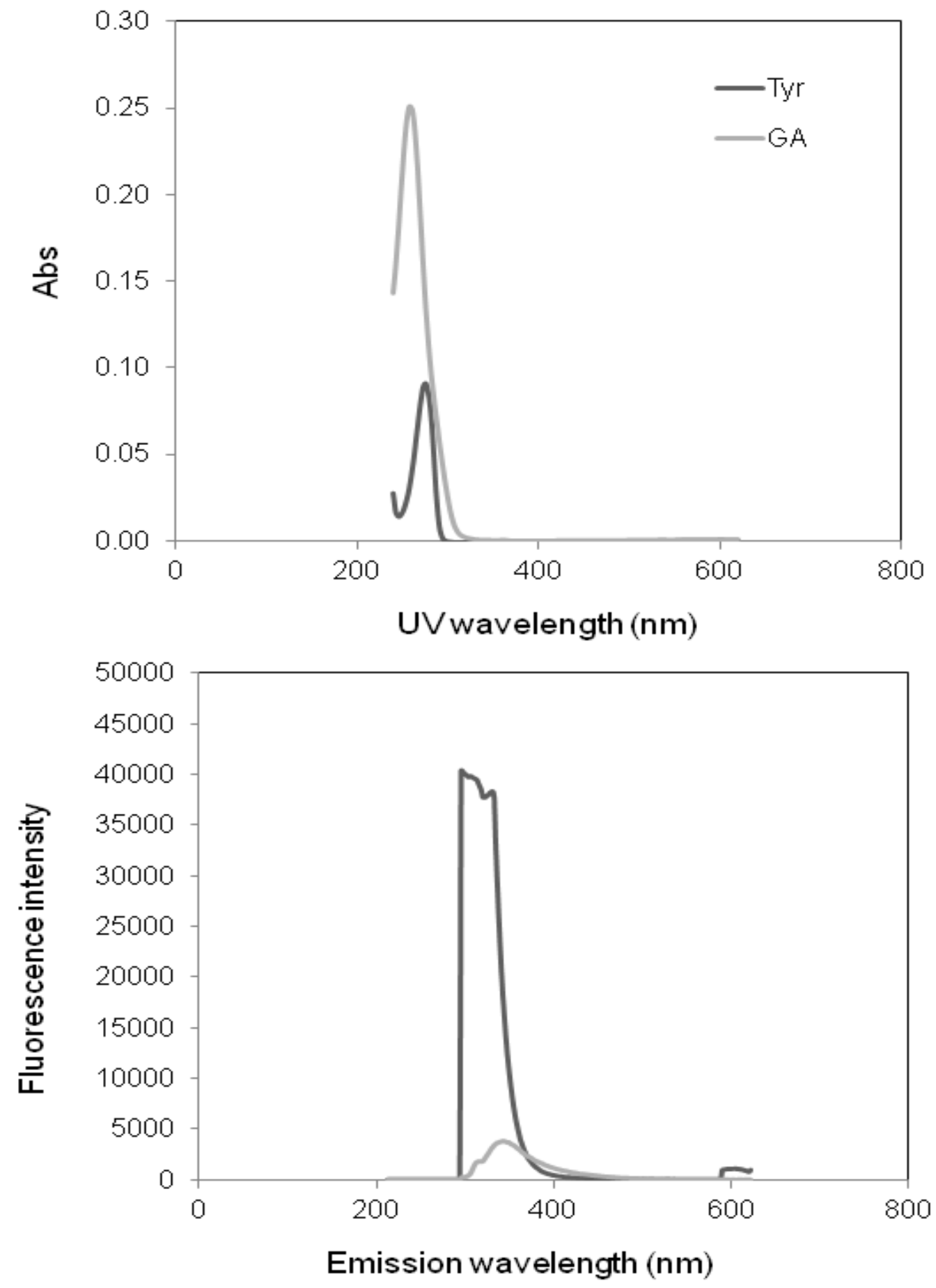

Figure 5.6 UV-Vis absorbance and Fluorescence $(\Lambda \mathrm{ex}=280 \mathrm{~nm})$ spectrum of tyrosine $(10$ ppm) and gallic acid (10 ppm) standard 


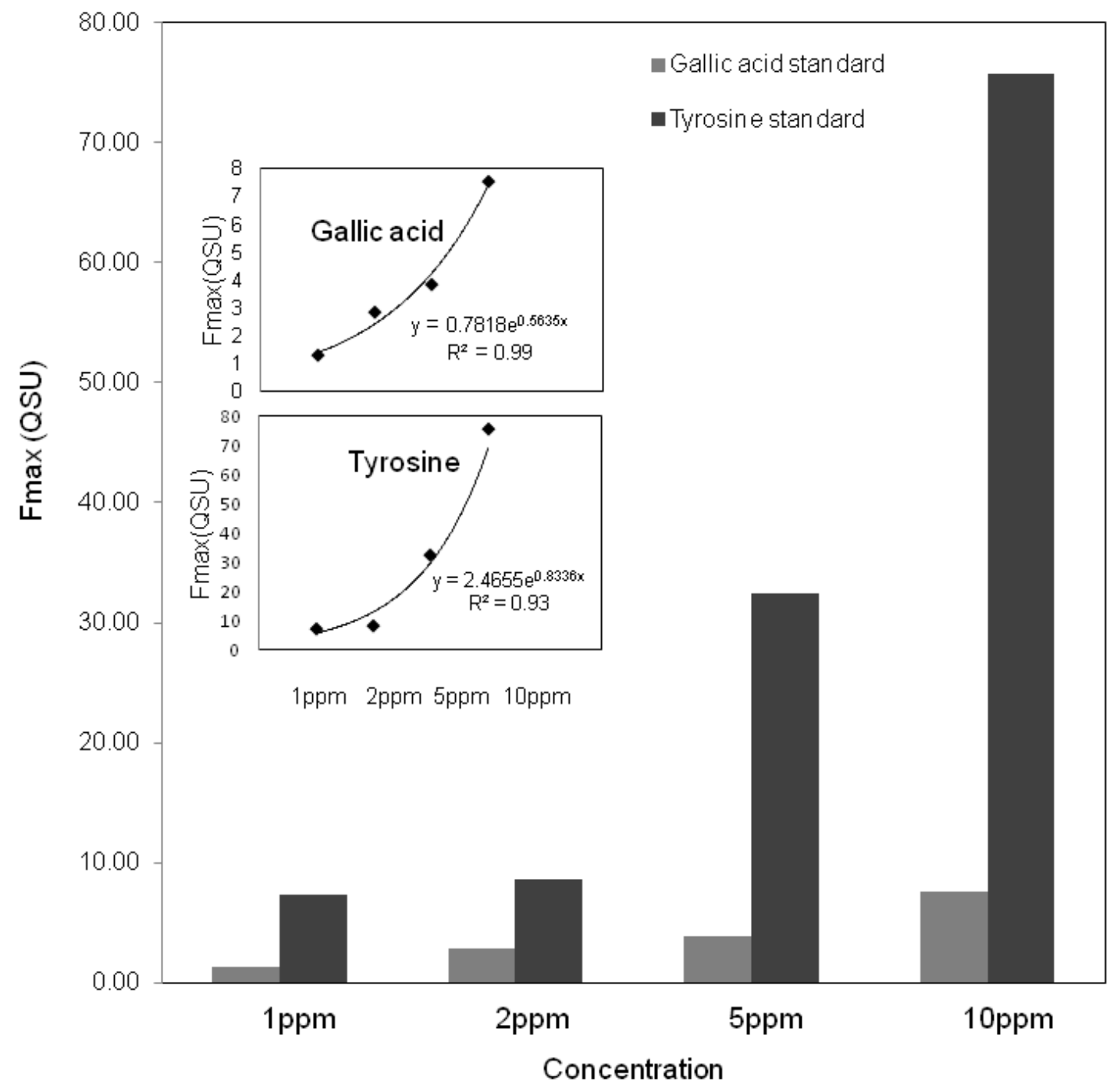

Figure 5.7 Fluorescence intensity of gallic acid and tyrosine standard at different concentration 
Table.5.2 Quantum yield calculated for gallic acid and tyrosine standard at different concentration

\begin{tabular}{cccc}
\hline & & Gallic acid & Tyrosine \\
\hline & $\mathrm{a}_{280}\left(\mathrm{~m}^{-1}\right)$ & 3.69 & 0.76 \\
$1 \mathrm{ppm}$ & quantum yield $(\varnothing)$ & 0.49 & 8.53 \\
\hline \multirow{3}{*}{$2 \mathrm{ppm}$} & $\mathrm{a}_{280}\left(\mathrm{~m}^{-1}\right)$ & 8.57 & 2.70 \\
& quantum yield $(\varnothing)$ & 0.40 & 2.85 \\
5 & $\mathrm{a}_{280}\left(\mathrm{~m}^{-1}\right)$ & 11.23 & 2.90 \\
$5 \mathrm{ppm}$ & quantum yield $(\varnothing)$ & 0.37 & 8.74 \\
\hline & $\mathrm{a}_{280}\left(\mathrm{~m}^{-1}\right)$ & 22.23 & 16.39 \\
$10 \mathrm{ppm}$ & quantum yield $(\varnothing)$ & 0.33 & 3.20 \\
\hline
\end{tabular}

\subsubsection{GC-MS analysis on gallic acid and hydrolyzed tannins}

Quantitative analysis of gallic acid in the hydrolysate extracts was conducted for the determination of total gallotannins. Two different depolymerization methods have been reported as applicable for tannins: direct transformation of gallotannins into gallic acid using enzymes and acid hydrolysis. Treatment of hydrolysable tannins using either method will split them into sugar and gallic acid. However, the hydrolysis effect by enzymatic methods has not been well studied, Therefore, the method used in this study is based on the modified acid hydrolysis method (Inoue and Hagerman 1988). Different hydrolysis conditions have been reported to depolymerize tannins. For hydrolysable tannins, $3 \% \mathrm{HCl}$ has been widely used and proved to be efficient in depolarizing gallotannins in complex matrixes (Fechtal and Riedl 1991). The heating duration was 27 $\mathrm{h}$ in the original method developed by Inoue and Hagerman (1988). However, many studies have reported $4 \mathrm{~h}$ of hydrolysis time as sufficient for the detection of gallic acid. Ossipov et al. (1997) compared different heating duration periods and concluded that reaction time of $4 \mathrm{~h}$ ensured the best hydrolysis efficiency. The above described 
hydrolysis method is optimal for hydrolysable tannins while for acid hydrolysis of condensed tannins, both the acid used and heating duration should be changed (Hernes and Hedges, 2000).

After acidic hydrolysis, we extracted the hydrolysate using three types of organic solvents: dichloromethane (DCM, 99.9\%), ethanol (5\%) + ethyl acetate, and pure ethyl acetate. The highest extraction efficiency $(88.0 \% \pm 6.8 \%)$ was found using $5 \%$ ethanol + ethyl acetate compared with the DCM $(1.24 \% \pm 0.0 \%)$ and ethyl acetate $(76.4 \% \pm 7.1 \%)$. Therefore, the mixture of 5\% ethanol in ethyl acetate was chosen for the final liquidliquid extraction method. This method has been used in the determination of gallic acid in biological matrices such as plants and proved to show the best recoveries of pyrogallol and gallic acid (Tor et al., 1996; Hernes et al., 2001)

External calibration plots for the gallic acid analysis were produced by plotting the ratio of the peak areas against the analyte concentration in the injected solution. Linearity was observed for gallic acid standard in both low concentration range ( 0.1 to 1 ppm, $\left.\mathrm{R}^{2}>0.998\right)$ and high concentration range ( $1 \mathrm{ppm}$ to $10 \mathrm{ppm}$, concentration range $\left.\mathrm{R}^{2}>0.997\right)$. Quantification based on external standard was based on injections of 20-100 ng of standards.

The calculation of MDL was based on the standard protocols published by USEPA (2010). Seven replicates of gallic acid standards were analyzed through the complete analytical processes (hydrolysis, extraction and derivatization). According to Tor et al. (1996), the injection of $0.2 \mathrm{ng}$ gallic acid standards into GC-MS gave an instrumental response of $\mathrm{S} / \mathrm{N} \mathrm{1:100}$ and the estimated detection limit is $0.5 \mathrm{mg} / \mathrm{L}$. The standard deviation from the seven measurements were multiplied by the student $t$ value 
$\left(t_{(7-1,99 \%)}=3.143\right)$. The MDL of this GC-MS method was $0.2 \mathrm{ppm}$. For quantification purpose, external calibration was based on injections of 1.6-80 $\mathrm{ng}$ of standards.

The method was validated by analyzing tannins extracted from senescent mangrove (Rhizophora mangle) leaves. The isolation and purification of mangrove tannins were described in Maie et al. (2008). The presence of gallic acid (Fig.5.8) in the hydrolysates was validated by comparing with the gallic acid standard and also by comparing the fragmentation patterns with those reported by several previous studies (Arpino et al., 1977; Proestos et al., 2006). Figure 5.8 shows the mass spectra of the TMS derivatives of gallic acid released from mangrove tannins. The total content of gallic acid in gallotannin of mangrove extract was $168.3 \pm 1.85 \mathrm{mg} \mathrm{g}^{-1}(\mathrm{n}=5)$ of dry mass. The content of gallotannins reported for young birch tree leaves was $14 \mathrm{mg} \mathrm{g}^{-1}$ of dry mass, and the total content varied from 3 to $30 \mathrm{mg} \mathrm{g}^{-1}$ among different trees (Ossipov et al., 1997). The gallic acid content in decaying mangrove leaves ranged from 0.02 to $0.30 \mathrm{mg} . \mathrm{g}^{-1}$ of ashfree dry weight (Hernes et al., 2001).

The level of gallic acid released through hydrolysis of different samples is listed in Table.5.3. Before hydrolysis, floc samples collected in freshwater marsh and mangrove marsh were analyzed and showed measurable free form gallic acid content of $0.07 \mathrm{mg} \mathrm{g}^{-1}$. Hydrolysis with $3 \% \mathrm{HCl}$ during $4 \mathrm{~h}\left(110^{\circ} \mathrm{C}\right)$ released significant amounts of gallic acid (Fig. 5.9). For floc samples collected at mangrove dominated sites, the content of gallic acid after hydrolysis increased by a factor of 1000 (Table 5.3). There was no detectable free form gallic acid in surface sediment samples but the signal of gallic acid was significantly enhanced after acid hydrolysis (Table 5.3). Overall, mangrove floc showed the most enriched gallic acid content. The stability of gallic acid during the hydrolysis 
was measured by spiking the gallic acid standard into $3 \% \mathrm{HCl}$ followed by the same analytical procedures (Fig.5.2). The average recovery of the complete analytical procedure was $91 \% \pm 2.7 \%$.

Table.5.3 Compare the gallic acid concentration measured by GC-MS in non-hydrolyzed sample and hydrolyzed samples

\begin{tabular}{lcc}
\hline & \multicolumn{2}{c}{ Gallic acid $\left(\mathrm{mg} . \mathrm{g}^{-1}\right)$} \\
\cline { 2 - 3 } Sample type & non-hydrolyzed & hydrolyzed \\
\hline $\begin{array}{l}\text { freshwater floc } \\
(\mathrm{n}=6)\end{array}$ & $0.07 \pm 0.04$ & $1.9 \pm 0.02$ \\
$\begin{array}{l}\text { mangrove floc } \\
(\mathrm{n}=6)\end{array}$ & 0.01 & $10.3 \pm 0.01$ \\
$\begin{array}{l}\text { surface sediment } \\
(\mathrm{n}=6)\end{array}$ & N.D & $6.0 \times 10^{-5}$ \\
$\begin{array}{l}\text { mangrove tannins } \\
(\mathrm{n}=3)\end{array}$ & N.A & $168.3 \pm 1.85$ \\
\hline
\end{tabular}

*Note: $\mathrm{N} . \mathrm{D}=$ not detected

N.A $=$ not accessible 

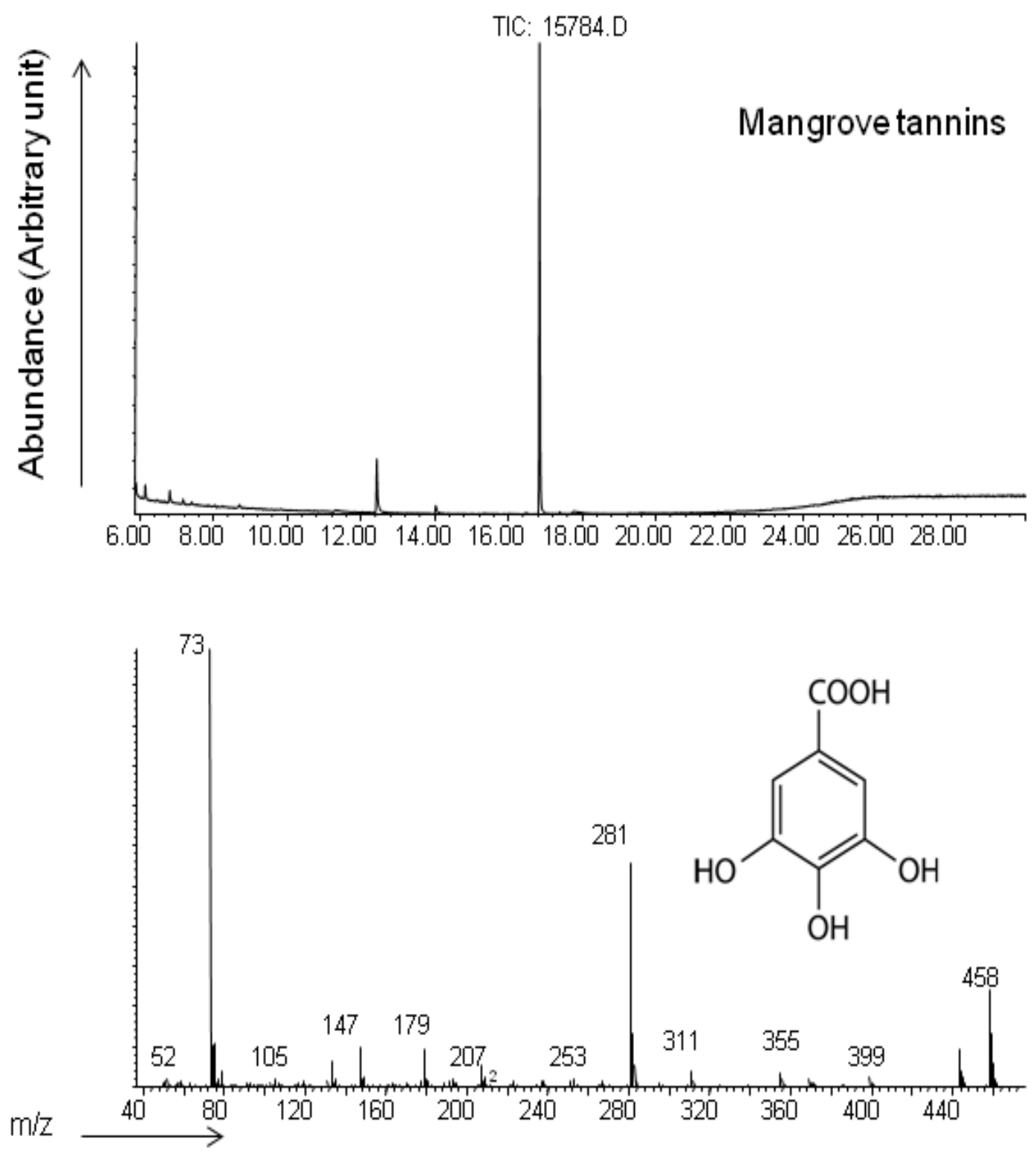

Figure.5.8 GC-MS detection on the hydrolyzed mangrove tannins 


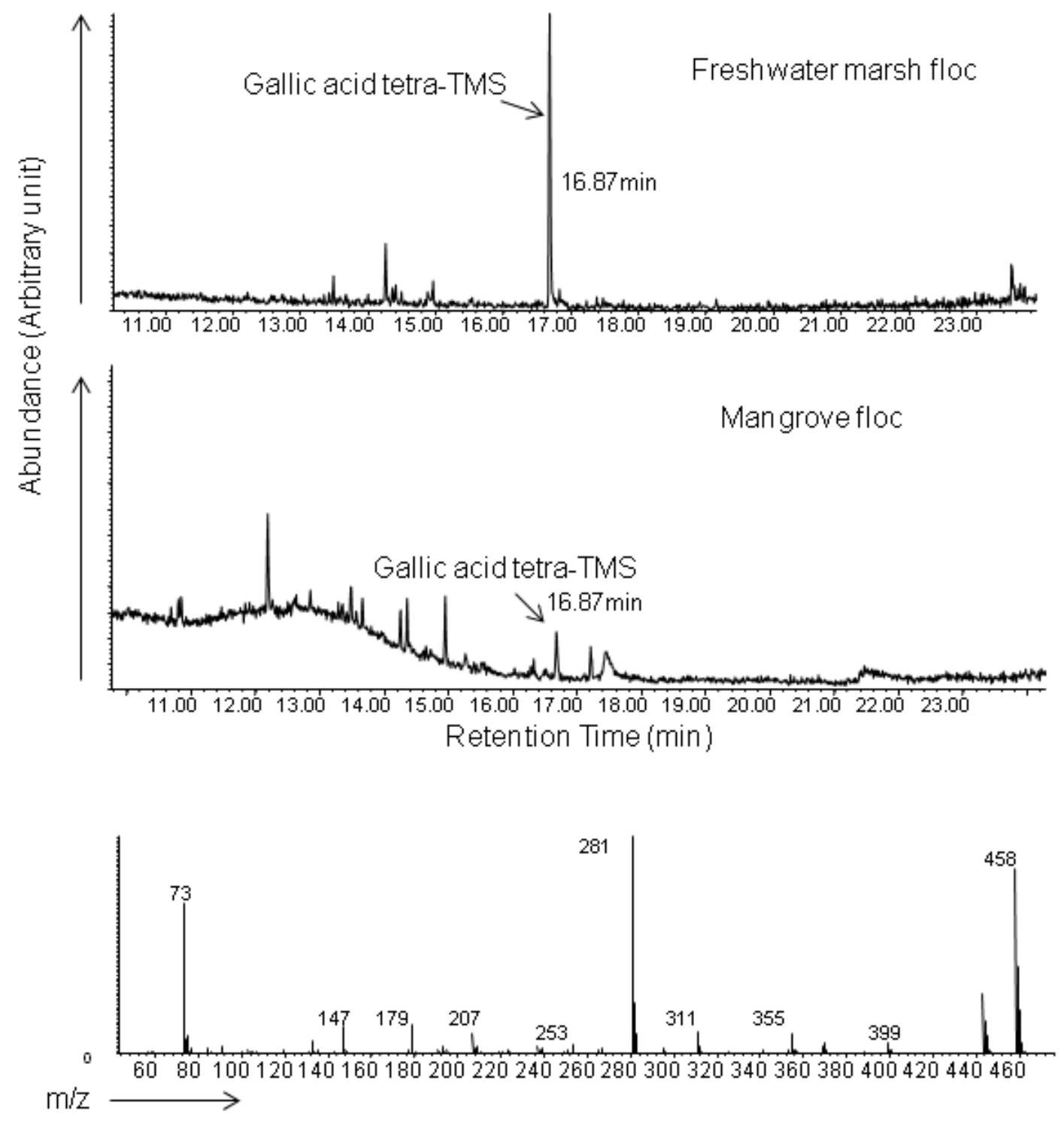

Figure.5.9 Gallic acid detected in floc samples (freshwater and mangrove floc) after acid hydrolysis.

\subsubsection{GC-MS analysis on tyrosine and hydrolyzed protein}

Although N,O-Bis (trimethylsilyl) trifluoroacetamide (BSTFA) derivatization is already widely used for amino acids (Stalling et al.,1968; Bergstöm et al., 1971; 1970) and for GC/C/IRMS, which has proved applicable to separate the ten most abundant 
amino acid in biological samples (An et al., 2013), this method does not provide high yields of silylated tyrosine in natural organic matter samples with only 1 out of 18 fortified matrix samples $\left(6 \mathrm{M} \mathrm{HCl}\right.$, heated under $110^{\circ} \mathrm{C}$ for $\left.22 \mathrm{~h}\right)$ detected by GC-MS in our study (Table.5.4). Fortified matrix samples $(n=12)$ and fortified blanks $(n=11)$ were prepared. The tyrosine fortification level was $\sim 200 \mathrm{ng}$ (injected amount). Compared with direct derivatization on tyrosine standard (Fig.5.10A), the silylation was significantly suppressed in acidified standard solutions and fortified DOM samples and thus did not successfully separate the tyrosine from the chromatogram (Fig.5.10B). The poor performance of BSTFA silylation is possibly due to the sterically hindered hydroxylbonded carbon (Št'ávová et al., 2011) or may be related to high interferences from solvents, derivatization agents, and matrix, which has been reported as common issues in the analysis of low molecular weight monocarboxylic (MCAs) and dicarboxylic acids (DCAs) (Sun et al., 2008; Beiner et al., 2009) . 
Table.5.4 GC-MS detection results of tyrosine standard, acidified tyrosine standard and fortified DOM samples

\begin{tabular}{|c|c|c|c|c|}
\hline Sample type & $\begin{array}{c}\text { number of } \\
\text { replicates }\end{array}$ & Sample treatment & Derivatization condition & $\begin{array}{l}\text { Tyr } \\
\text { detected }\end{array}$ \\
\hline $\begin{array}{l}\text { Tyr standard } \\
\text { (solid) }\end{array}$ & 5 & direct derivatization & $\begin{array}{l}\text { 100ul acetonitrile }+100 \mathrm{ul} \\
\text { BSTFA } 30 \mathrm{C} 50 \mathrm{~min}\end{array}$ & possitive \\
\hline $\begin{array}{l}\text { Tyr standard } \\
\text { (solution) }\end{array}$ & 5 & dissolved in $0.1 \mathrm{~N} \mathrm{HCl}$; dried under $\mathrm{N} 2$; & $\begin{array}{l}\text { 100ul acetonitrile }+100 \mathrm{ul} \\
\text { BSTFA } 30 \mathrm{C} 50 \mathrm{~min}\end{array}$ & possitive \\
\hline $\begin{array}{l}\text { Tyr standard } \\
\text { (solution) }\end{array}$ & 6 & dissolved in $6 \mathrm{M} \mathrm{HCl}$; dried under $\mathrm{N} 2$; & $\begin{array}{l}\text { 100ul acetonitrile }+100 \mathrm{ul} \\
\text { BSTFA } 30 \mathrm{C} 50 \mathrm{~min}\end{array}$ & possitive \\
\hline Tyr +UDOM & 3 & dissolved in $6 \mathrm{M} \mathrm{HCl}$; hydrolyzed $110^{\circ} \mathrm{C}, 22 \mathrm{~h}$; & $\begin{array}{l}\text { 100ul acetonitrile }+100 \mathrm{ul} \\
\text { BSTFA 30C } 50 \mathrm{~min}\end{array}$ & N.D \\
\hline UDOM(solid) & 3 & dissolved in $6 \mathrm{M} \mathrm{HCl}$; hydrolyzed $110^{\circ} \mathrm{C}, 22 \mathrm{~h}$; & $\begin{array}{l}\text { 100ul acetonitrile }+100 \mathrm{ul} \\
\text { BSTFA } 30 \mathrm{C} 50 \mathrm{~min}\end{array}$ & N.D \\
\hline
\end{tabular}

**Note: N.D = not detected

$\sim 0.1 \mathrm{mg}$ of tyrosine standard (solid) and $\sim 0.1 \mathrm{mg}$ of UDOM samples were mixed for each test 

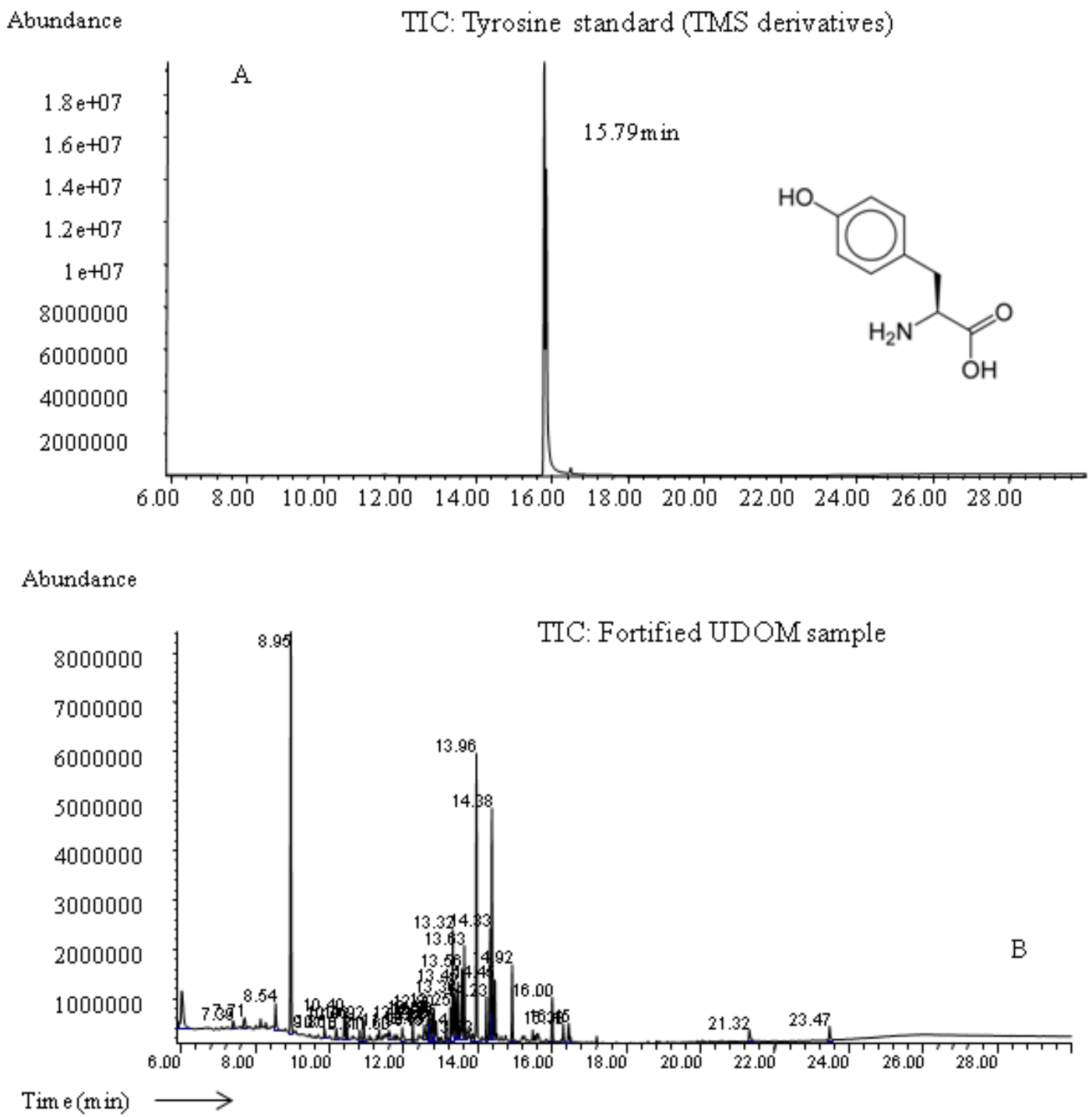

Figure 5.10 A.TIC chromatogram of tyrosine standard derivatized by BSTFA; B.

Fortified UDOM sample matrix using tyrosine standard at concentration level of 2000ng (injected amount)

Therefore, an alternative derivatization method, esterification-acylation, has been tested for amino acid analysis using acidified isopropanol (IP) and trifluoroacetic anhydride (TFAA) (Macko et al., 1997). Compared with BSTFA derivatization, IP- 
TFAA method gives higher signal yield in the subsequent GC-MS analysis with weighted peak area significantly higher than BSTFA derivatization (Fig.5.11). This derivatization method readily target highly polar, multi-functional compounds, such as carbohydrates and amino acids. In order to validate the IP-TFAA derivatizing method, three replicates of protein standard, BSA was hydrolyzed using the method described in section 5.2 and then converted into the volatile trifluoroacetyl-isopropyl esters compounds. Through the use of IP-TFAA, we were able to separate the tyrosine from other amino acids in the hydrolyzed BSA (Fig.5.12a): the tyrosine peak was identified at retention time of 31.89 min confirmed by the MS fragmentation pattern and by comparing with the trifluoroacetyl-isopropyl esters of tyrosine standard. Compared with IP-TFAA, the BSTFA method was largely affected by matrix that showed high baseline and unresolved peaks (Fig.5.12b) and thus tyrosine was not detected in the fortified blank and samples. Silylation reagents and trimethylsilyl derivatives are hydrolytically unstable and easily affected by the presence of active $\mathrm{H}^{+}$(Bazan et al., 1982), which is in fact responsible for matrix effect and bad GC separation. The within-batch analytical precision based on replicated tyrosine standards is $0.023 \mathrm{mg} \mathrm{mL}^{-1}$. 


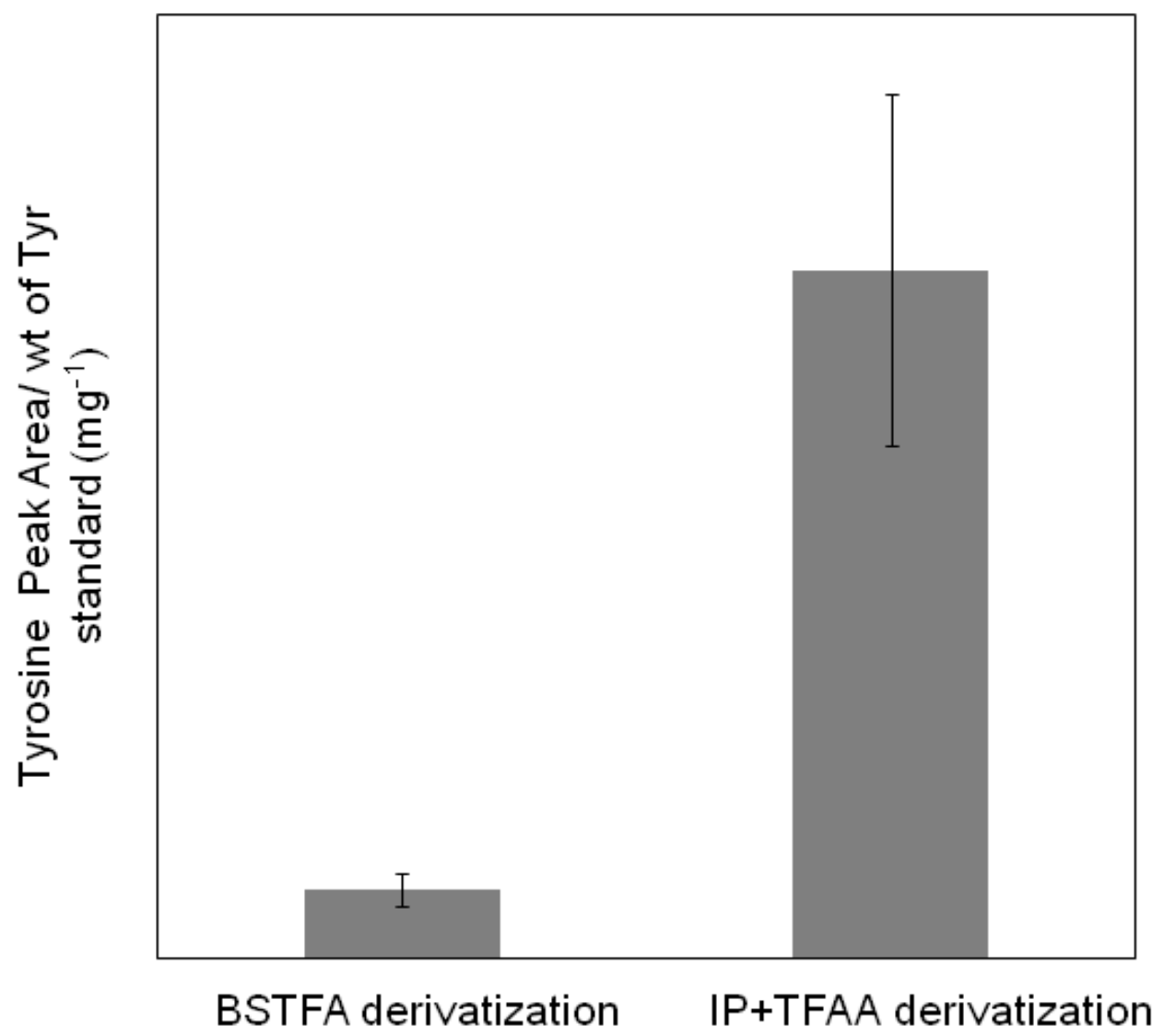

Figure 5.11 Comparison of GC-MS detection on tyrosine standard using BSTFA and $\mathrm{IP}+\mathrm{TFAA}$ as derivatizing agent 

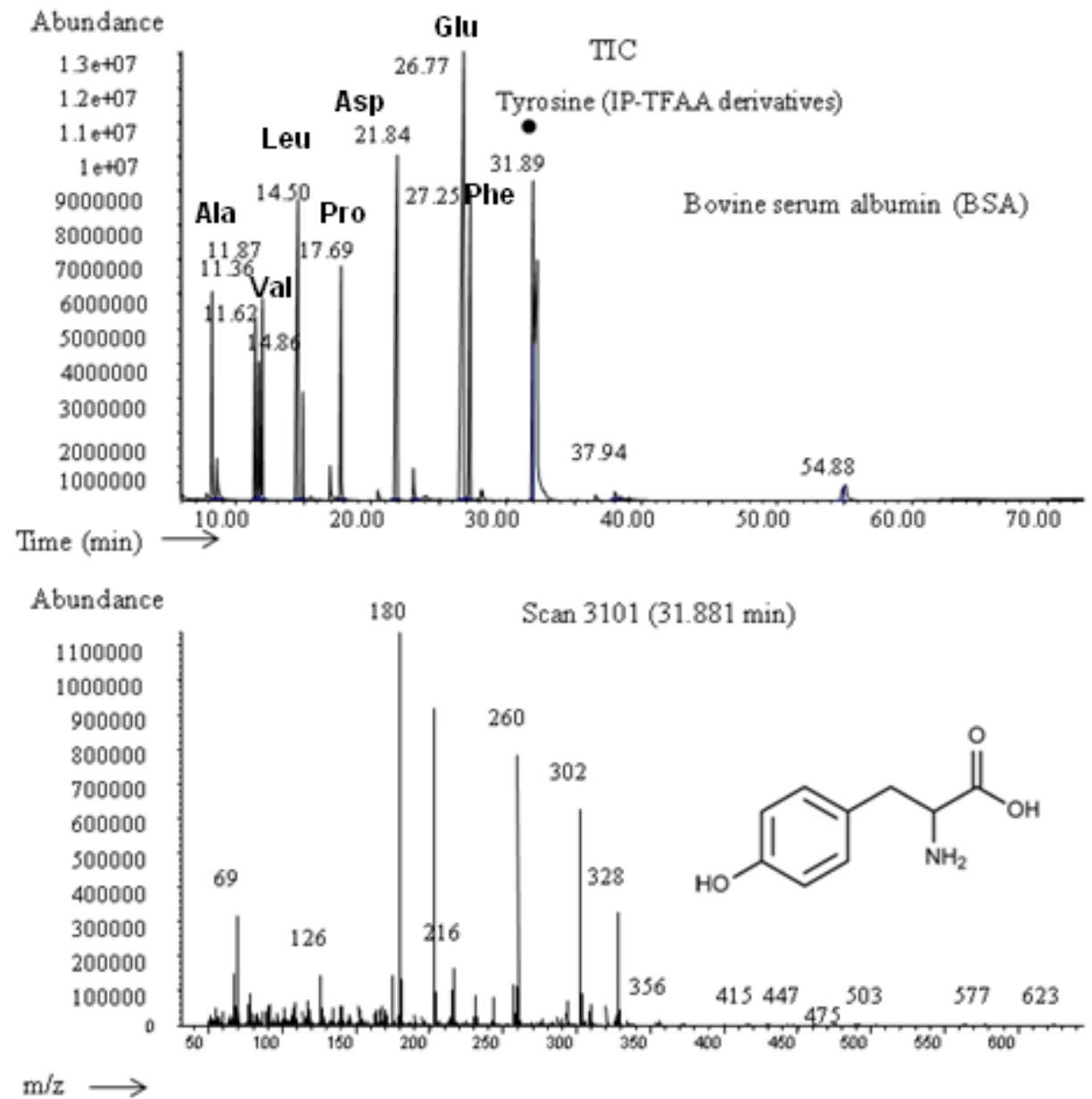

Figure 5.12a TIC chromatogram of IP-TFAA derivatives of amino acid in hydrolyzed BSA protein standard 


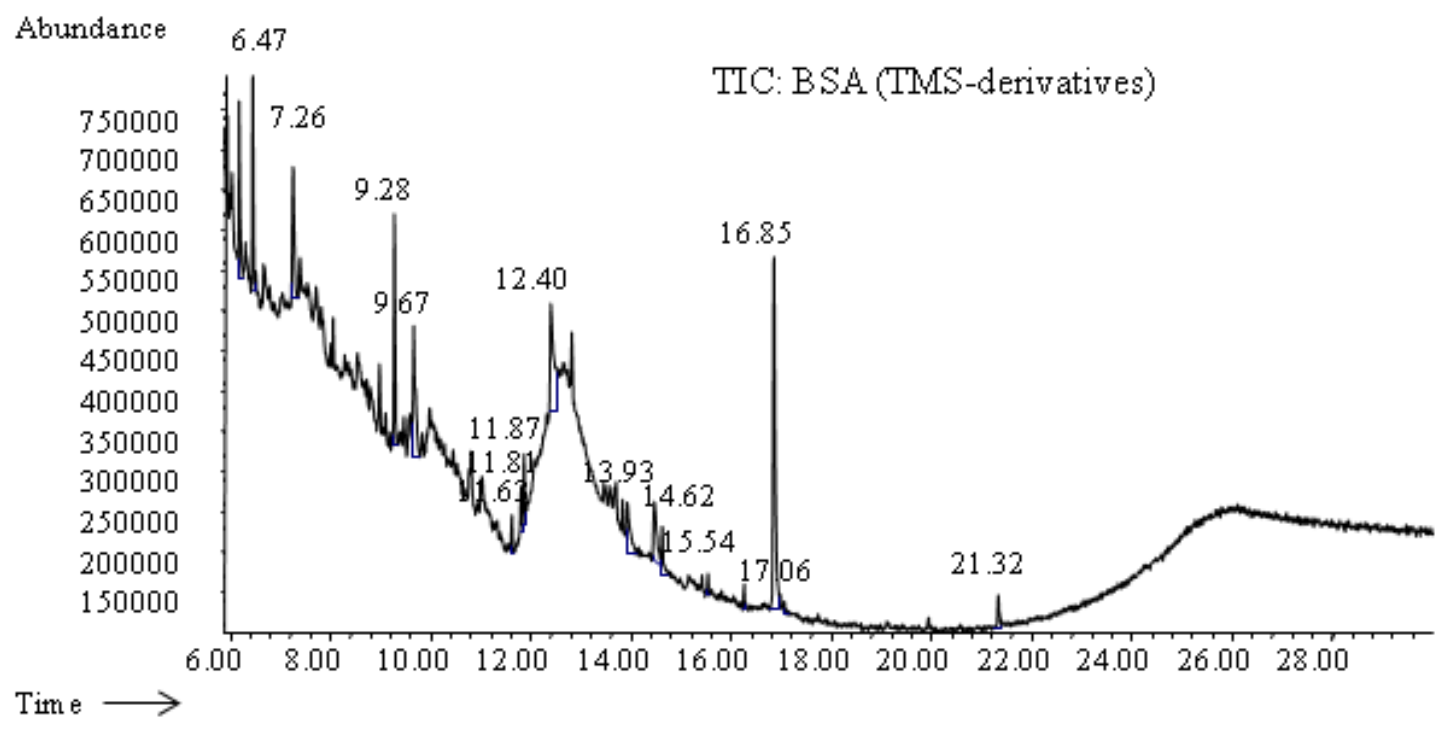

Figure 5.12b TIC chromatogram of BSTFA derivatives of amino acid in hydrolyzed BSA protein standard

5.4.5 Comparing the strengths of gallic acid vs. tyrosine in the protein-like fluorescence

Both freshwater marsh and mangrove floc samples exhibited significant $\mathrm{T}$ peak in their EEM scans (Fig.5.13). PARAFAC results showed 16-18\% of protein-like component in the floc's base-extract. While mangrove detritus is considered a major OM source material of floc the contribution of gallotannin (gallic acid) might be significant in the observed protein-like fluorescence. To assess the strengths of gallic acid vs. tyrosine in the protein-like fluorescence, the ratio of the fluorescence intensity (Flu) of these two compounds were calculated as:

$\mathrm{Flu}_{(\mathrm{Tyr})}: \mathrm{Flu}_{(\mathrm{GA})}=[\mathrm{Tyr}] \varnothing_{\mathrm{Tyr}}:[\mathrm{GA}] \varnothing_{\mathrm{GA}}$ 

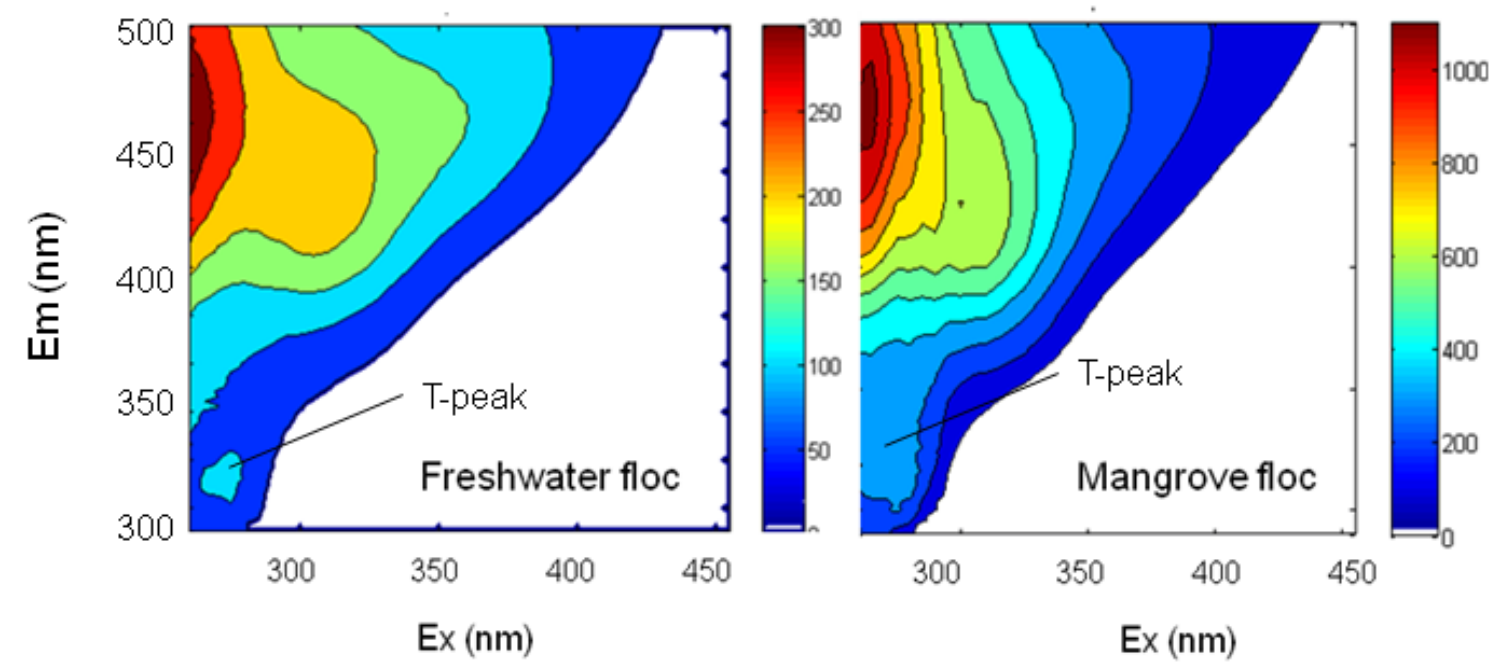

Figure 5.13 Representative EEMs of floc base-extract

Table 5.5 Concentration of gallic acid, tyrosine and their contribution to protein-like fluorescence in OM samples

\begin{tabular}{ccc}
\hline Sample type & floc & floc \\
\hline Sampling site & Freshwater marsh & Mangrove marsh \\
gallic acid concentration $(\mathrm{mg} / \mathrm{g})$ & $1.9 \pm 0.02$ & $10.3 \pm 0.01$ \\
gallic acid\% in protein-like & & \\
fluorophores & $49.7 \%$ & $100 \%$ \\
tyrosine concentration $(\mathrm{mg} / \mathrm{g})$ & $0.25 \pm 0.11$ & N.D \\
tyrosine $\%$ in protein-like \\
fluorophores
\end{tabular}

Data obtained using this estimation approach suggest that the protein-like fluorescence in mangrove floc is mainly contributed from its gallic acid content $\left(10.3 \pm 0.01 \mathrm{mg} \mathrm{g}^{-1}\right)$, with no detectable contributions of tyrosine (Table 5.5). The overlapped fluorescence region of tyrosine and gallic acid ( Ex/Em 275/335 nm) which has been traditionally assigned as tyrosine-like peak turns out to be entirely derived from gallic acid (Table 5.5) for this example sample. Freshwater marsh showed slightly different composition in the protein-like components with the gallic acid content $\sim 14$ times more abundant than tyrosine (Table 5.5). However, the quantum yield of tyrosine 
$\left(\varnothing_{\mathrm{Tyr}}=2.86\right)$ is $\sim 23$ times that of the gallic acid $\left(\varnothing_{\mathrm{GA}}=0.37\right)$ at their corresponding concentration. Therefore, the overall contribution of both gallic acid and tyrosine to the fluorescence $\mathrm{T}$ peak is roughly equal with $49.7 \%$ and $50.3 \%$, respectively (Table 5.5).

\subsection{Conclusions}

In this study, we used GC-MS analysis and fluorescence quantum yield calculation in an attempt to assess the strengths of hydrolyzable tannins and amino acid in their contribution to the protein-like fluorescence. The analytical methods for the quantification of gallic acid showed a rather large dynamic range with demonstrated high sensitivity. The acid hydrolysis followed by a one-step derivatization can be quickly applied for environmental samples (e.g. POM, soil, floc and sediments) and therefore could be used for large-scale sample surveys. In addition to gallic acid, many other phenolic compounds such as lignin phenols (Rodríguez-Delgado et al., 2001; Hernes et al., 2009) may also contribute to the protein-like fluorescence. However, lignins are inherently insoluble in water that oxidative degradation is needed for them to become water soluble. Tannins on the other hand are found abundant in mangroves, which dominate the water extractable portions of POM in our previous study. Therefore our research was primarily focused on the contributions to the protein-like fluorescence by gallotannins in comparison with the amino acids. For tyrosine analysis, the robustness of the analytical method has been tested with high reproducibility based on the measurements of replicated standards, which could combine with fluorescence data in an attempt to better establish the potential relationships between the protein-like fluorescence intensities with actual aromatic amino acids. The detailed examination of 
the traditionally defined protein-like fluorophores has revealed the heterogeneity of its constituents. Attentions have to be taken when using optical proxies to assess different ecological samples. The limitations of such proxies have been clearly demonstrated. Quantitatively, tannins could contribute more significantly to protein-like fluorescence compared with tyrosine, particularly in coastal OM samples where terrestrial sources such as higher plants detritus dominate the source material. When amino acids dominate, the bulk protein-like fluorescence might be representative of the dissolved organic nitrogen (DON), the traditionally identified, bioavailable portion of DOM. Overall, the composition of such protein-like fluorescence can be highly variable depending on different ecological regimes and therefore provide different ecological functions. 


\section{REFERENCE}

An, Y., Schwartz, Z., Jackson, G. P., 2013. $\delta^{13} \mathrm{C}$ analysis of amino acids in human hair using trimethylsilyl derivatives and gas chromatography/combustion/isotope ratio mass spectrometry. Rapid Communications in Mass Spectrometry 27, 1481-1489.

Alongi, D. M., 1987. The influence of mangrove-derived tannins on intertidal meiobenthos in tropical estuaries. Oecologia 71, 537-540.

Bao, H., Wu, Y., Tian, L., Zhang, J. and Zhang, G., 2013. Sources and distributions of terrigenous organic matter in a mangrove fringed small tropical estuary in South China. Acta Oceanologica Sinica 32, 18-26.

Bro, R., 1997. PARAFAC. Tutorial and applications. Chemometrics and Intelligent Laboratory Systems 38, 149-171.

Bushaw, K. L., Zepp, R. G., Tarr, M. A., Schulz-Jander, D., Bourbonniere, R. A., Hodson, R. E., Miller,W.L, Bronk,D.A., Moran, M. A.,1996. Photochemical release of biologically available nitrogen from aquatic dissolved organic matter. Nature 381, 404407.

Boyer, J.N., Fourqurean, J.W., Jones, R.D., 1997. Spatial characterization of water quality in Florida Bay and Whitewater Bay by multivariate analyses: zones of similar influence. Estuaries 20, 743-758.

Benner, R., Hatcher, P. G., Hedges, J. I., 1990. Early diagenesis of mangrove leaves in a tropical estuary: Bulk chemical characterization using solid-state ${ }^{13} \mathrm{C}$ NMR and elemental analyses. Geochimica et Cosmochimica Acta 54, 2003-2013.

Boto, K. G., Bunt, J. S., Wellington, J. T., 1984. Variations in mangrove forest productivity in northern Australia and Papua New Guinea. Estuarine, Coastal and Shelf Science 19, 321-329.

Beiner, K., Plewka, A., Haferkorn, S., Iinuma, Y., Engewald, W., Herrmann, H., 2009. Quantification of organic acids in particulate matter by coupling of thermally assisted hydrolysis and methylation with thermodesorption-gas chromatography-mass spectrometry. Journal of Chromatography A 1216, 6642-6650.

Bergström, K., Gürtler, J., 1970. Trimethylsilylation of amino acids. II. Gas chromatographic and structural studies on trimethylsilyl derivatives of straight chain amino acids. Acta Chemica Scandinavica 25, 175-188. 
Bazan, A.C., Knapp, D.R., 1982. Improved derivative of 6-keto-prostaglandin F1a for gas chromatographic-mass spectrometric analysis. Journal of Chromatography A 236, 201-207.

Coble, P. G., Schultz, C. A., Mopper, K., 1993. Fluorescence contouring analysis of DOC intercalibration experiment samples: a comparison of techniques. Marine Chemistry 41, 173-178.

Coble, P.G., 1996. Characterization of marine and terrestrial DOM in seawater using excitation-emission matrix spectroscopy. Marine Chemistry 51, 325-346.

Coble, P. G., 2007. Marine optical biogeochemistry: the chemistry of ocean color. Chemical Reviews 107, 402-418.

Del Vecchio, R., Blough, N. V., 2004. On the origin of the optical properties of humic substances. Environmental Science and Technology 38, 3885-3891.

Fellman, J. B., Hood, E., Spencer, R. G., 2010. Fluorescence spectroscopy opens new windows into dissolved organic matter dynamics in freshwater ecosystems: A review. Limnology and Oceanography 55, 2452-2462.

Green, S. A., Blough, N. V., 1994. Optical absorption and fluorescence properties of chromophoric dissolved organic matter in natural waters. Limnology and Oceanography 39, 1903-1916.

Jones, V., Parish, K., Thomson, A., Wolff, G. A., Maie, N., Jaffé, R., 2006. Molecular characterization of proteinaceous material in the Florida coastal Everglades. Hydrobiologia 569, 129-133.

Osburn, C. L., Handsel, L. T., Mikan, M. P., Paerl, H. W.,Montgomery, M. T., 2012. Fluorescence tracking of dissolved and particulate organic matter quality in a riverdominated estuary. Environmental Science and Technology 46, 8628-8636.

Stedmon, C.A., Bro, R., 2008. Characterizing dissolved organic matter fluorescence with parallel factor analysis: a tutorial. Limnology and Oceanography. Methods 6, 572-579.

Stalling, D. L., Gehrke, C. W., Zumwalt, R. W., 1968. A new silylation reagent for amino acids bis (trimethylsilyl) trifluoroacetamide (BSTFA). Biochemical and Biophysical Research Communications 31, 616-622.

Št’ávová, J., Beránek, J., Nelson, E. P., Diep, B. A., Kubátová, A., 2011. Limits of detection for the determination of mono-and dicarboxylic acids using gas and liquid chromatographic methods coupled with mass spectrometry. Journal of Chromatography B 879, 1429-1438. 
Sun, S. H., Xie, J. P., Xie, F. W., Zong, Y. L., 2008. Determination of volatile organic acids in oriental tobacco by needle-based derivatization headspace liquid-phase microextraction coupled to gas chromatography/mass spectrometry. Journal of Chromatography A 1179, 89-95.

Santin, C., Yamashita, Y., Otero, X. L., Alvarez, M. A., Jaffé, R., 2009. Characterizing humic substances from estuarine soils and sediments by excitation-emission matrix spectroscopy and parallel factor analysis. Biogeochemistry 96, 131-147.

Scully, N. M., Maie, N., Dailey, S. K., Boyer, J. N., Jones, R. D., Jaffé, R., 2004. Early diagenesis of plant-derived dissolved organic matter along a wetland, mangrove, estuary ecotone. Limnology and Oceanography 49, 1667-1678.

Tor, E. R., Francis, T. M., Holstege, D. M.,Galey, F. D., 1996. GC/MS determination of pyrogallol and gallic acid in biological matrices as diagnostic indicators of oak exposure. Journal of Agricultural and Food Chemistry 44, 1275-1279.

Hernes, P. J., Bergamaschi, B. A., Eckard, R. S., Spencer, R. G., 2009.

Fluorescence-based proxies for lignin in freshwater dissolved organic matter. Journal of Geophysical Research 114,G00F03.

Hernes, P. J., Hedges, J. I., 2000. Determination of condensed tannin monomers in environmental samples by capillary gas chromatography of acid depolymerization extracts. Analytical Chemistry 72, 5115-5124.

Hedges, J. I., Weliky, K., 1989. Diagenesis of conifer needles in a coastal marine environment. Geochimica et Cosmochimica Acta 53, 2659-2673.

Ishii, S. K., Boyer, T. H., 2012. Behavior of reoccurring PARAFAC components in fluorescent dissolved organic matter in natural and engineered systems: a critical review. Environmental Science and Technology 46, 2006-2017.

Jaffé R., Cawley K., and Yamashita Y., 2014. Applications of excitation emission matrix fluorescence with parallel factor analysis (EEM-PARAFAC) in assessing environmental dynamics of natural dissolved organic matter (DOM) in aquatic environments: A review. Advances in the Physicochemical Characterization of Organic Matter, ACS Series. 2773.

Kalle, K., 1949. Fluoreszenz und gelbstoff im bottnischen und finnischen meerbusen. Deutsche Hydrografische Zeitschrift 2, 117-124.

Keil, R. G., Kirchman, D. L., 1991. Dissolved combined amino acids in marine waters as determined by a vapor-phase hydrolysis method. Marine Chemistry 33, 243-259. 
Kelsey, R. G., Harmon, M. E., 1989. Distribution and variation of extractable total phenols and tannins in the logs of four conifers after 1 year on the ground. Canadian Journal of Forest Research 19, 1030-1036.

Lobbes, J. R. M., Fitznar, H. P., Kattner, G., 1999. High-performance liquid chromatography of lignin-derived phenols in environmental samples with diode array detection. Analytical Chemistry 71, 3008-3012.

Mopper, K., Schultz, C. A., 1993. Fluorescence as a possible tool for studying the nature and water column distribution of DOC components. Marine Chemistry 41, 229-238.

McCarthy, M., Pratum, T., Hedges, J., Benner, R., 1997. Chemical composition of dissolved organic nitrogen in the ocean. Nature 390, 150-154.

Melhuish, W. H., 1961. Quantum efficiencies of fluorescence of organic substances: effect of solvent and concentration of the fluorescent solute1. The Journal of Physical Chemistry 65, 229-235.

Maie, N., Scully, N. M., Pisani, O., Jaffé, R., 2007. Composition of a protein-like fluorophore of dissolved organic matter in coastal wetland and estuarine ecosystems. Water Research 41, 563-570.

Maie, N., Behrens, A., Knicker, H., Kögel-Knabner, I., 2003. Changes in the structure and protein binding ability of condensed tannins during decomposition of fresh needles and leaves. Soil Biology and Biochemistry 35, 577-589.

Maie, N., Pisani, O., Jaffé, R., 2008. Mangrove tannins in aquatic ecosystems: Their fate and possible influence on dissolved organic carbon and nitrogen cycling. Limnology and Oceanography 53, 160-171.

Mayer, L. M., Schick, L. L., Loder III, T. C., 1999. Dissolved protein fluorescence in two Maine estuaries. Marine Chemistry 64, 171-179.

Macko, S. A., Uhle, M. E., Engel, M. H., Andrusevich, V., 1997. Stable nitrogen isotope analysis of amino acid enantiomers by gas chromatography/combustion/isotope ratio mass spectrometry. Analytical Chemistry 69, 926-929.

Proestos, C., Sereli, D., Komaitis, M., 2006. Determination of phenolic compounds in aromatic plants by RP-HPLC and GC-MS. Food Chemistry 95, 44-52.

Reynolds, D. M., 2003. Rapid and direct determination of tryptophan in water using synchronous fluorescence spectroscopy. Water Research 37, 3055-3060. 
Rodrıguez-Delgado, M. A., Malovaná, S., Pérez, J. P., Borges, T., Garcia Montelongo, F. J., 2001. Separation of phenolic compounds by high-performance liquid chromatography with absorbance and fluorimetric detection. Journal of Chromatography A 912, 249-257.

Wu, F., Tanoue, E., 2001. Sensitive determination of dissolved tryptophan in freshwater by alkaline hydrolysis and HPLC. Analytical Sciences 17, 1063-1066.

Weishaar, J. L., G. R. Aiken, B. A. Bergamaschi, M. S. Fram, R.Fujii and K. Mopper, 2003. Evaluation of specific ultraviolet absorbance as an indicator of the chemical composition and reactivity of dissolved organic carbon. Environmental Science and Technology 37, 4702-4708

Yang, L., Hur, J., 2014. Critical evaluation of spectroscopic indices for organic matter source tracing via end member mixing analysis based on two contrasting sources. Water Research 59, 80-89.

Yamashita, Y., Tanoue, E., 2003. Chemical characterization of protein-like fluorophores in DOM in relation to aromatic amino acids. Marine Chemistry 82, 255-271.

Zuloaga, O., Prieto, A., Ahmed, K., Sarkar, S. K., Bhattacharya, A., Chatterjee, M., Deb Bhattacharya,B., Satpathy, K. K., 2013. Distribution of polycyclic aromatic hydrocarbons in recent sediments of Sundarban mangrove wetland of India and Bangladesh: a comparative approach. Environmental Earth Sciences 68, 355-367. 
APPENDICES 
Appendix 2.1

Cluster analysis based on EEM-PARAFAC results of the sampling sites in Florida Bay (average of early wet, late wet and dry season).

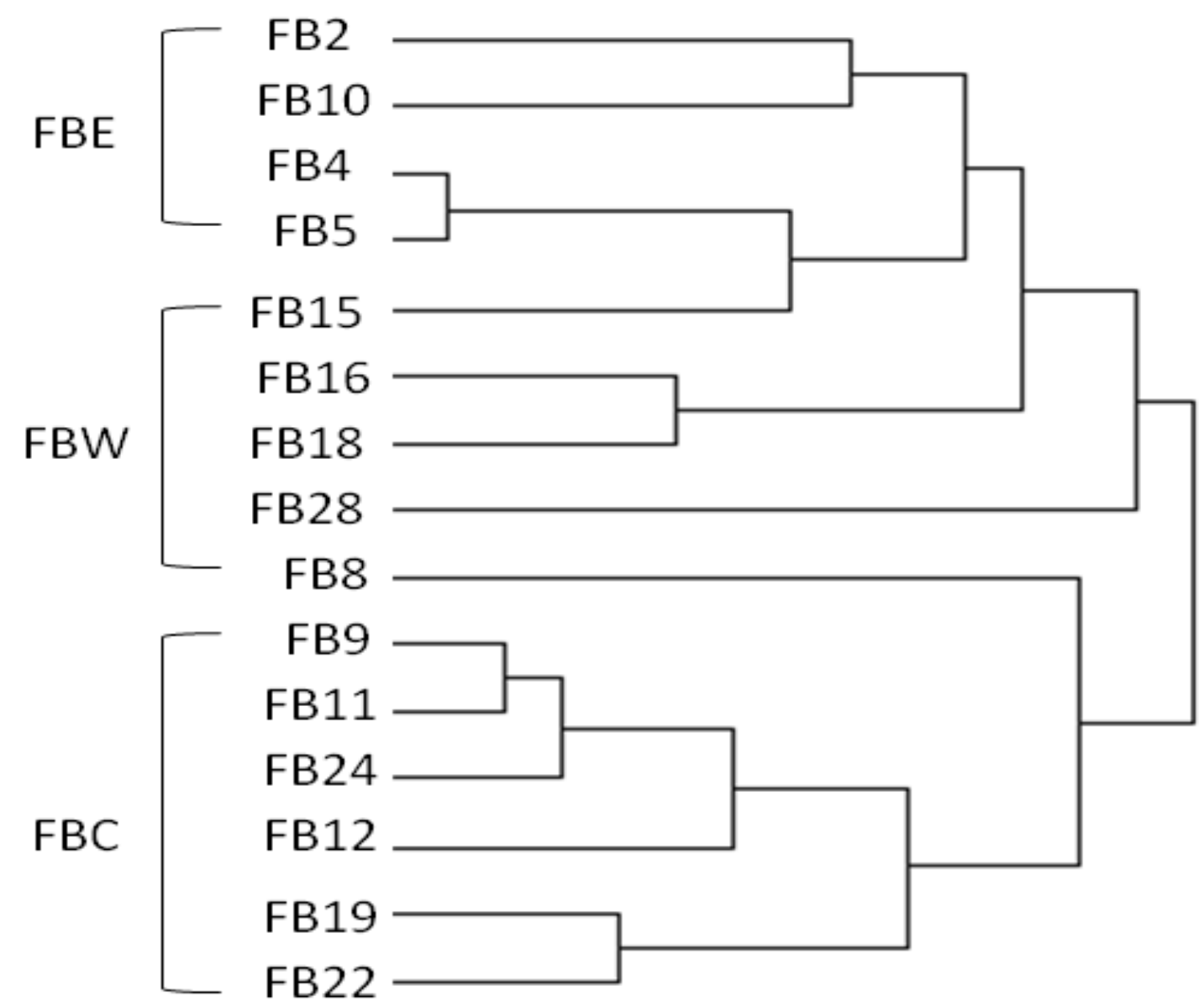




\section{Appendix 2.2}

Correlation between stable carbon isotope ratio $\delta^{13} \mathrm{C}$ and the relative abundance of EEMPARAFAC components (Humic-like and protein-like) for early wet season (June 2011), late wet season (November 2011) and dry season (April 2012). 95\% confidence interval for the regression is indicated.

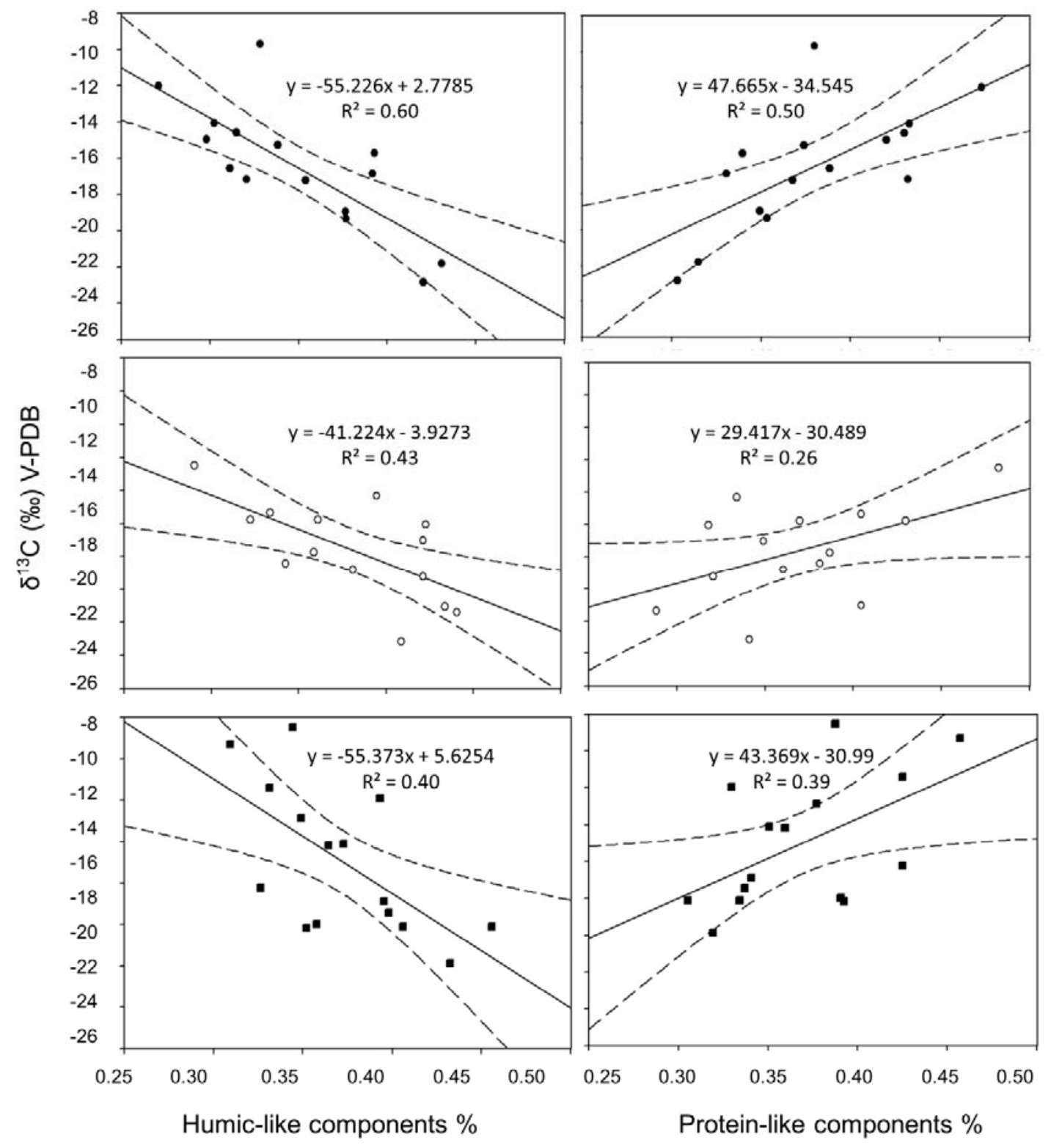


Appendix 2.3

Comparisons on the seagrass proportioning in the DOM pool calculated by IsoSource simulation (three end-member mixing) and two end-member mass balance calculation

\begin{tabular}{llcc}
\hline Region & Season & $\begin{array}{c}\text { Seagrass } \\
\text { proportion (\%) }\end{array}$ & $\begin{array}{c}\text { IsoSource } \\
\text { simulation(\%) }\end{array}$ \\
\hline FBE & early wet & 46 & $46-48$ \\
& late wet & 33 & $33-36$ \\
& dry & 52 & $47-50$ \\
FBC & early wet & 70 & $67-68$ \\
& late wet & 43 & $46-48$ \\
& dry & 72 & $74-75$ \\
FBW & early wet & 43 & $44-46$ \\
& late wet & 49 & $47-50$ \\
& dry & 72 & $73-74$ \\
\hline
\end{tabular}


Appendix 3.1

Representative EEMs of plant (Spartina and Juncus) and soil leachate

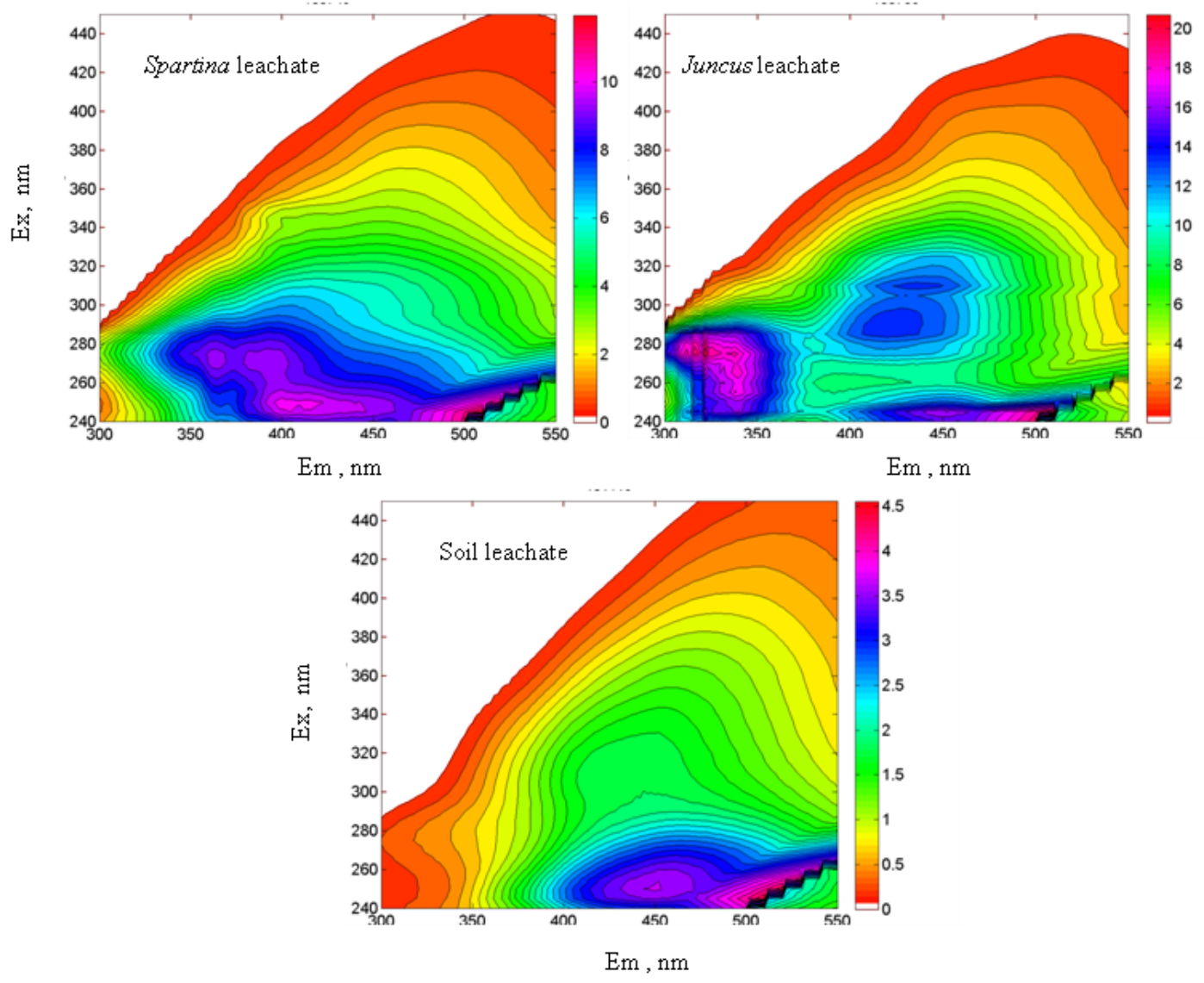


Appendix 4.1

Variation of Chl- $\alpha$, Fmax, C4, C7 and C8 along the Harney River estuary during wet (A) and dry $(\mathrm{B})$ season
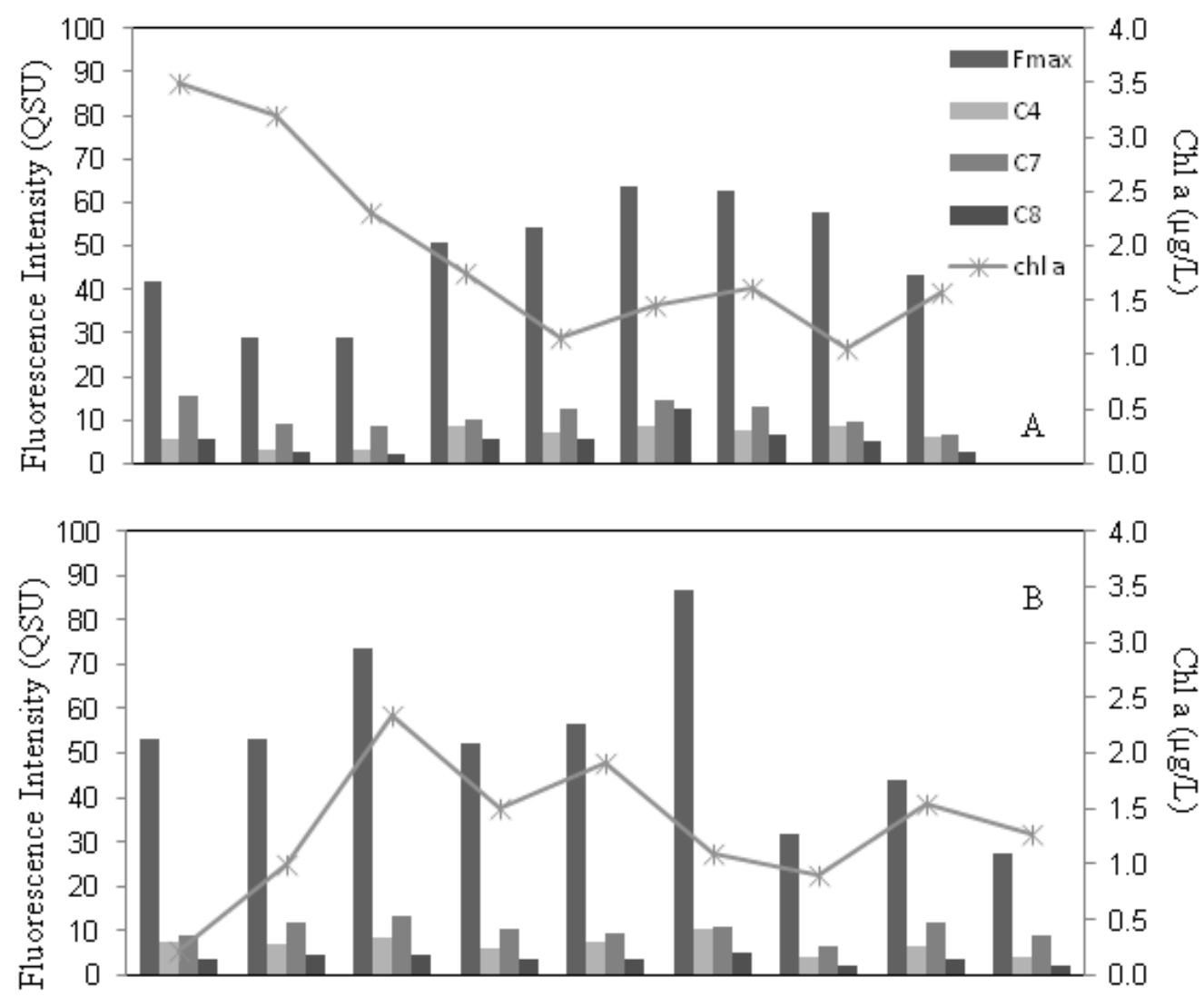

Freshwater

Lower Estuary 
VITA

\section{CHAO YA}

Born, Szechuan, China

2006-2010

B.A., Ocean University of China, Qingdao, China

2010-present Teaching Assistant

Florida International University

Miami, Florida

Cristina Menendez Fellowship

Southeast Environmental Research Center

Miami, Florida

Doctoral Candidate

Florida International University

Miami, Florida

Research Assistant

Florida International University

Miami, Floria

\section{PUBLICATIONS AND PRESENTATIONS}

Chao Ya, William Anderson, Rudolf Jaffé. Assessing dissolved organic matter dynamics and source strengths in a subtropical estuary: application of stable carbon isotopes and optical properties. Continental shelf research. (under revision)

Chao Ya, Wenxi Huang, Ding He, Rudolf Jaffé, Organic Matter dynamics in a mangrove-dominated estuary: comparisons between dissolved and particulate organic matter, JASM, 2014, Portland, USA.

Chao Ya, Wenxi Huang, Ding He, Rudolf Jaffé, Organic Matter dynamics in a mangrove-dominated estuary: comparisons between dissolved and particulate organic matter, ACS-FAME, 2014, Tampa, USA.

Chao Ya, William Anderson, Rudolf Jaffé, Assessing dissolved organic matter dynamics and source strengths in a subtropical estuary: application of stable carbon isotopes and optical properties, ASLO, 2013, New Orleans, USA. 
Chao Ya, Rudolf Jaffé, Using multi-proxy techniques in characterizing natural organic matter in estuarine ecosystems, AAPG-SEG, 2013, Houston, USA.

Ding He, Kaelin Cawley, Laura Belicka, Chao Ya, Sasha Wagner, Annie Palya, William Anderson, and Rudolf Jaffé, Characterization of particulate, dissolved, and black carbon exports from the Shark River Estuary, FCE-ASM, 2012, Miami, USA. 